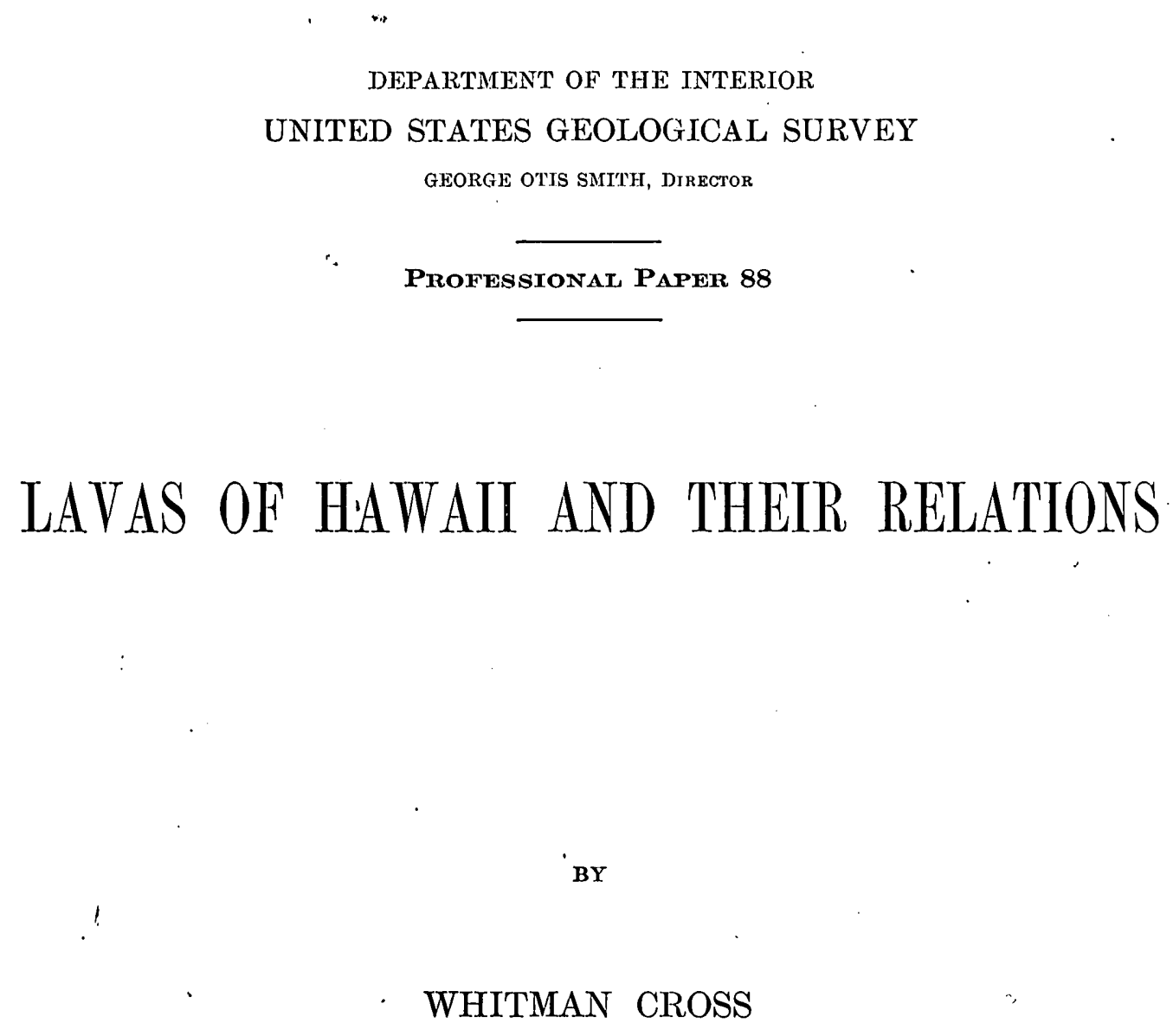

WHITMAN CROSS

WASHINGTON

GOVERNMENT PRINTING OFFICE

1915 


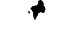




\section{CONTENTS.}

Page.

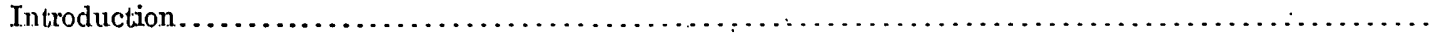

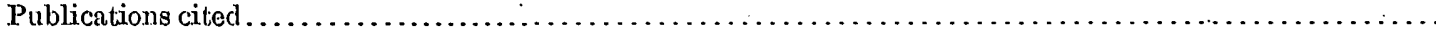

Petrography

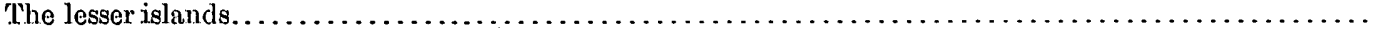

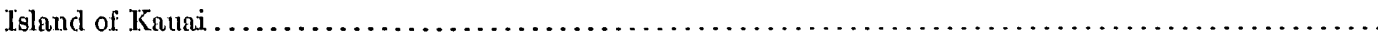

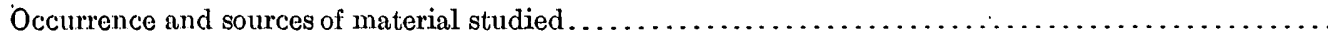

Olivine-plagioclase basalt.

General characters . :

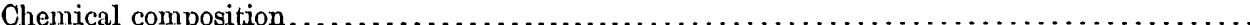

Quantitative classification.

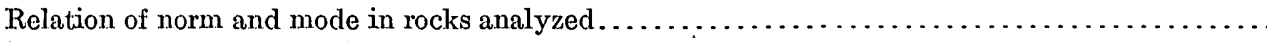

Plagioclase basalt (poor in olivine)

Limburgite

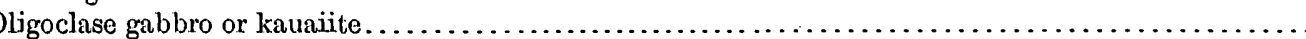

Occurrence.

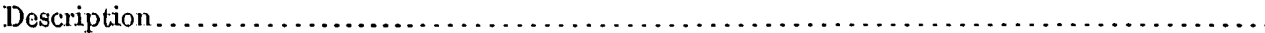

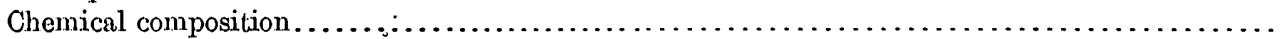

Quantitative classification.

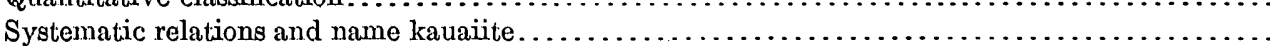

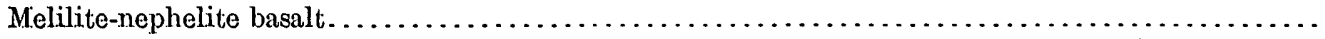

Occurrence.

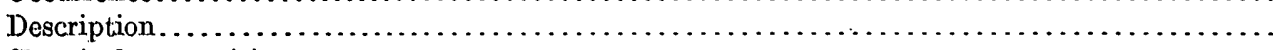

Chemical composition.

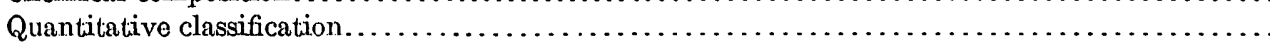

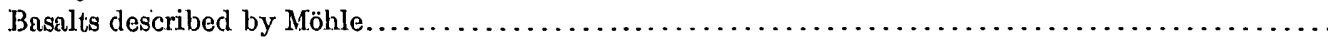

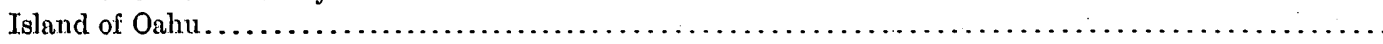

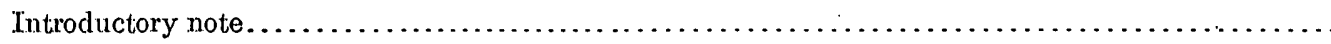

Range of lavas.

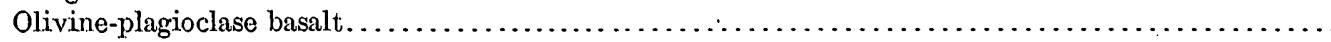

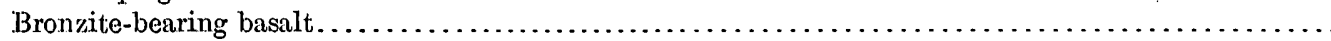

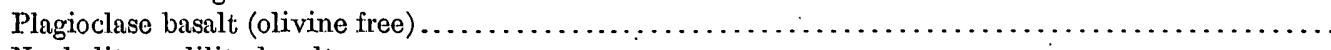

Nephelite-melilite basalt .

Occurrence . . . . . . . . . . . . .

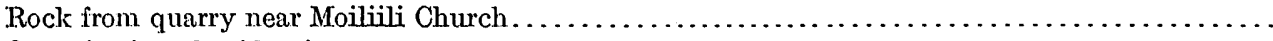

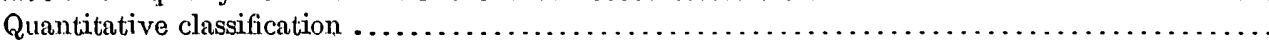

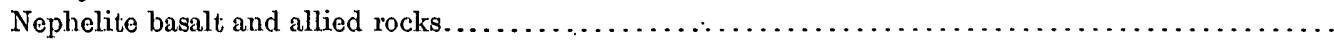

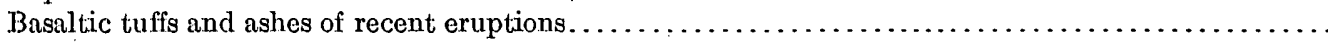

Island of Molokai.

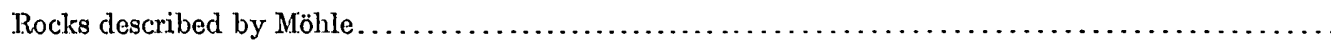

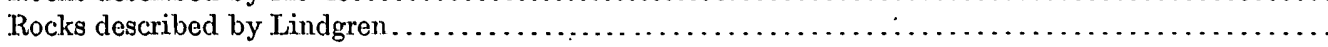

Tsland of Maui.

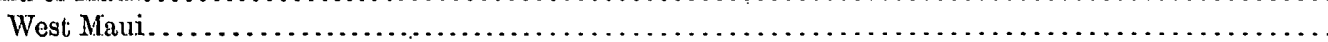

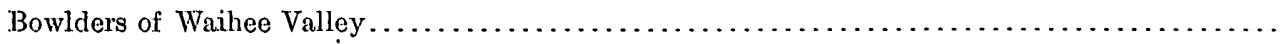

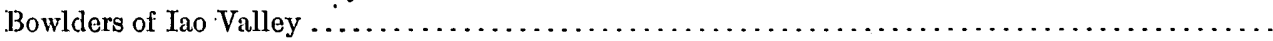

Rocks described by Möhle.

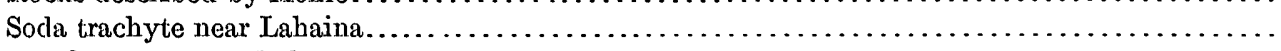

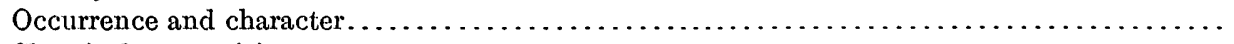

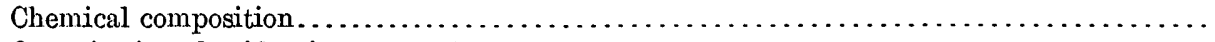

Quantitative classification 
Petrography-Continued.

Island of Maui-Continued. $\quad$ Page.

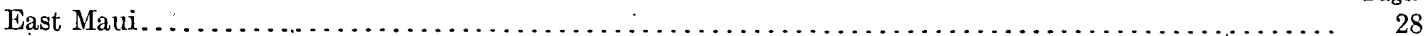

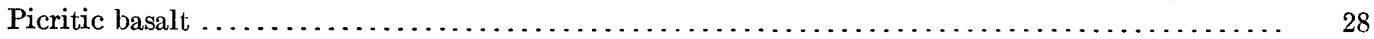

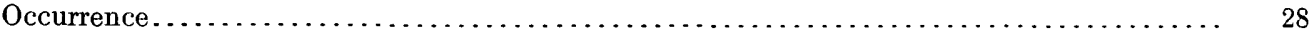

Description. . . . . . . . . . . .

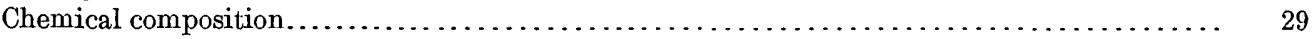

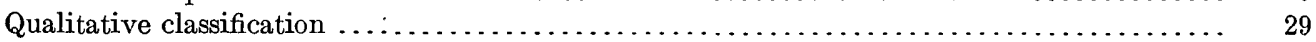

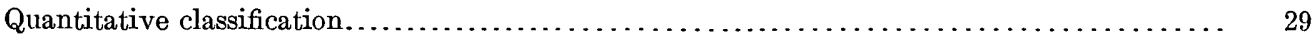

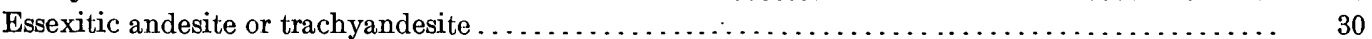

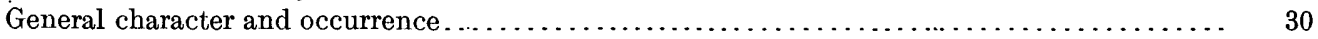

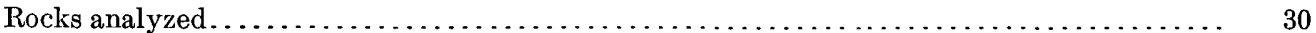

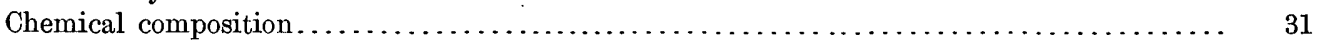

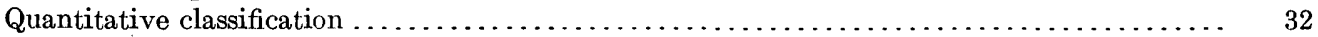

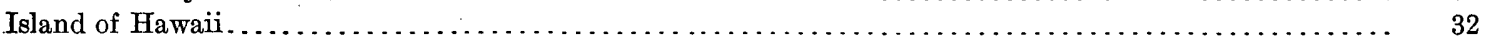

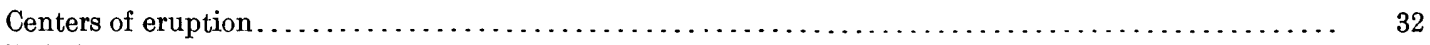

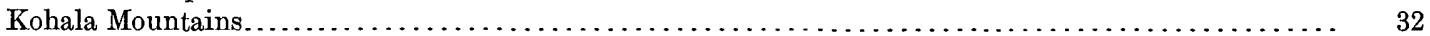

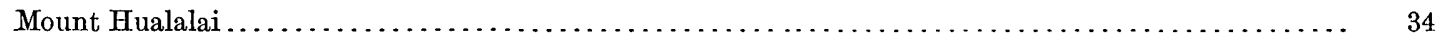

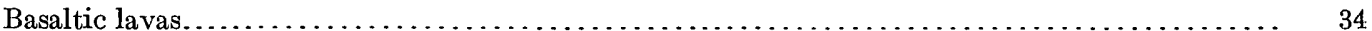

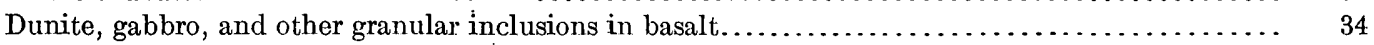

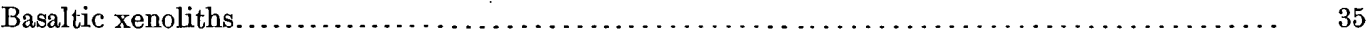

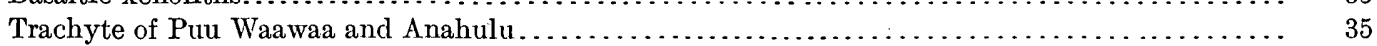

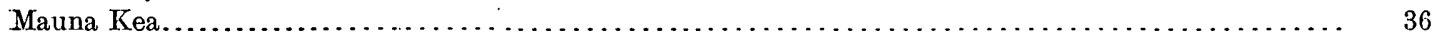

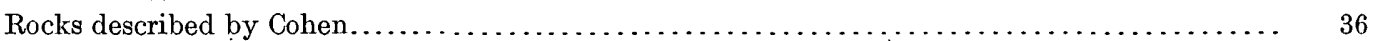

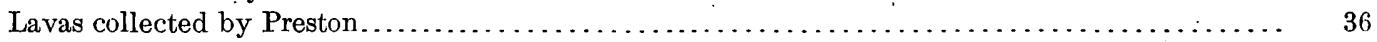

Observations of Dutton. . . . . . . . .

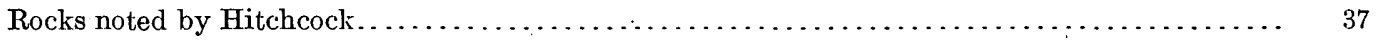

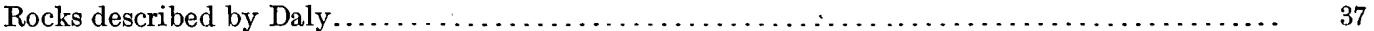

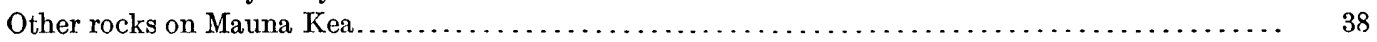

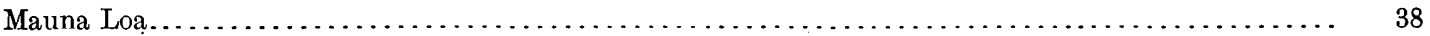

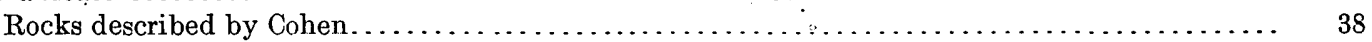

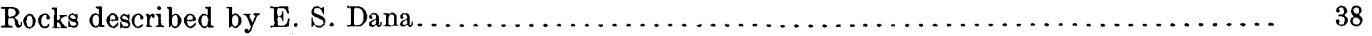

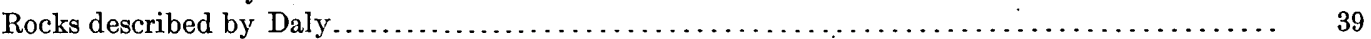

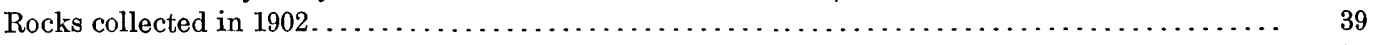

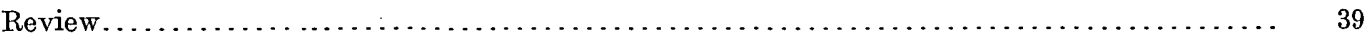

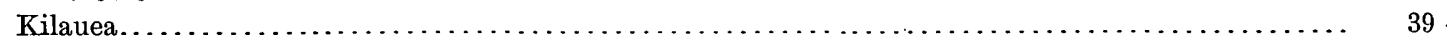

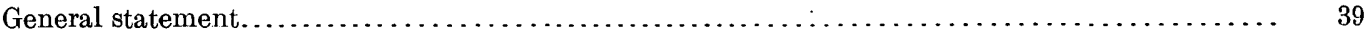

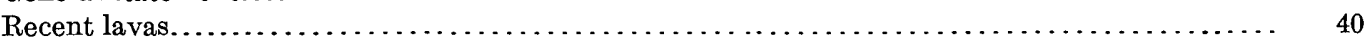

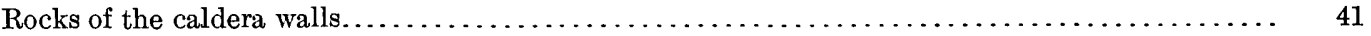

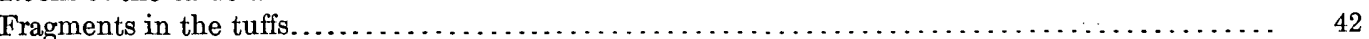

Gabbro of Uwekahuna "laccolith" ............................................ 43

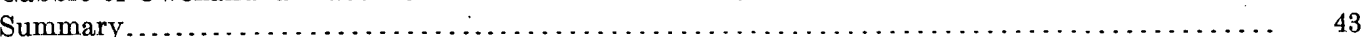

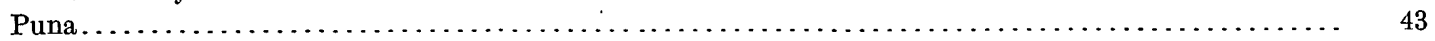

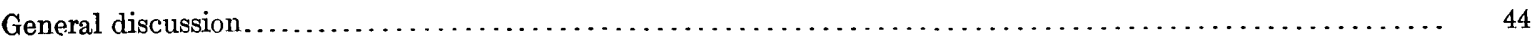

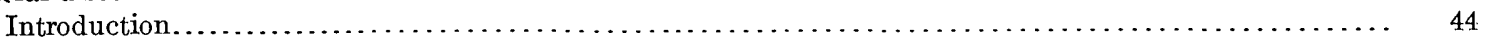

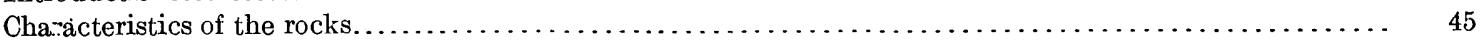

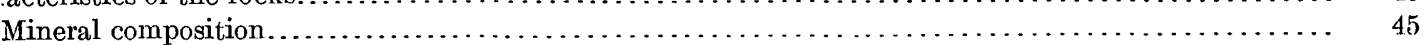

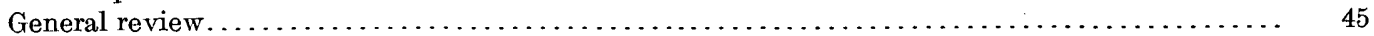

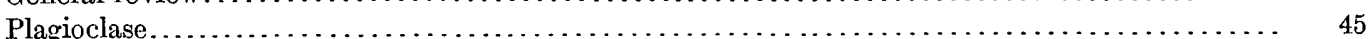

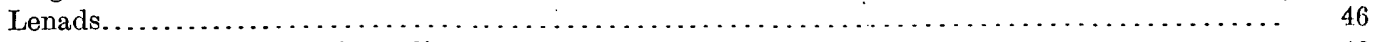

Quartz, tridymite, and cristobalite . . . . . . . . . . . . . . . . .

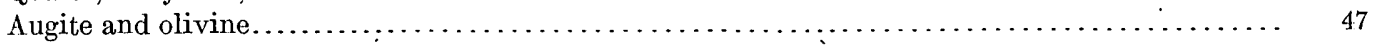

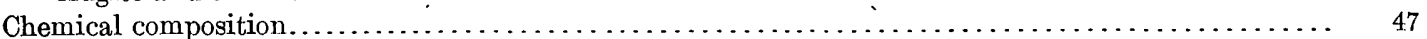

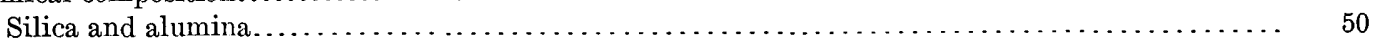

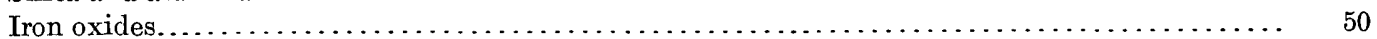

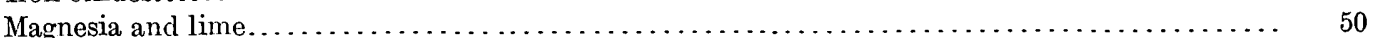

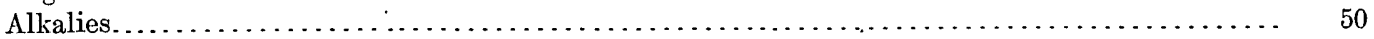

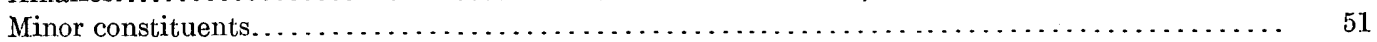

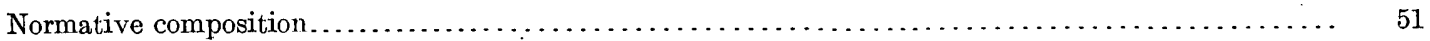

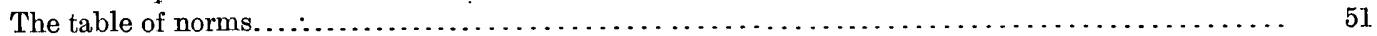

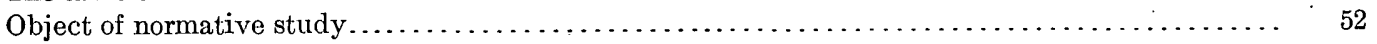

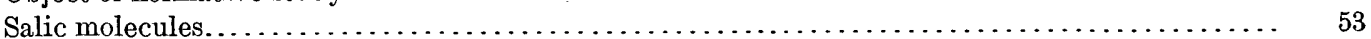

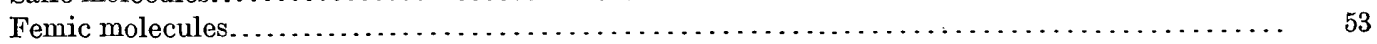

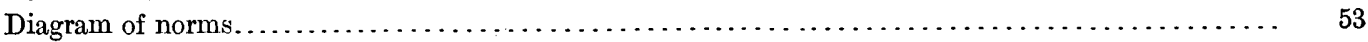


General discussion-Continued.

Characteristics of the rocks-Continued.

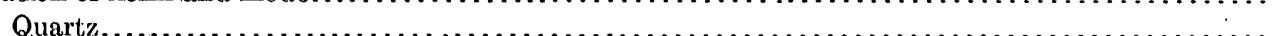

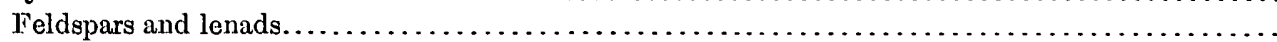

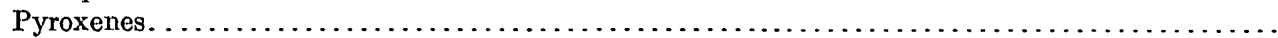

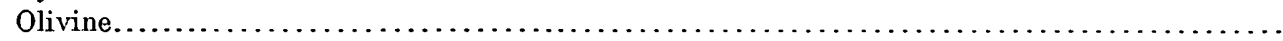

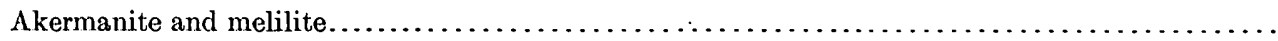

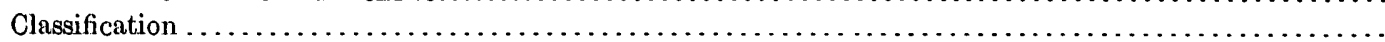

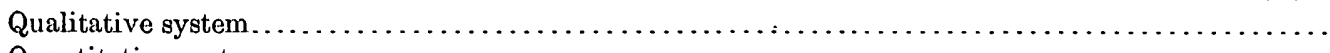

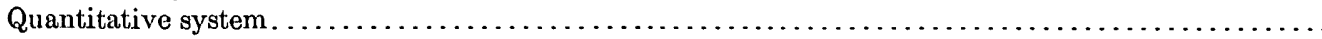

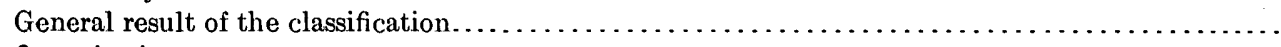

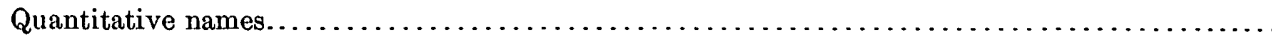

Groups under the quantitative system.........

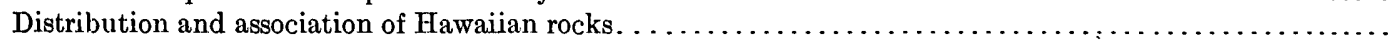

In the Hawaiian group.

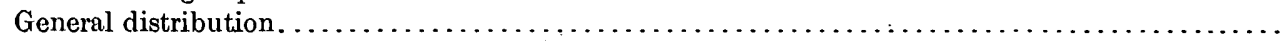

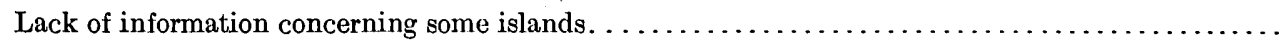

Associated lavas of Kilauea. . . . . . . . . . .

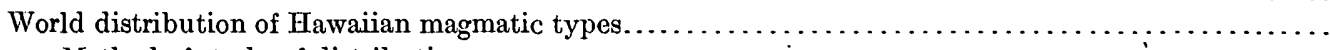

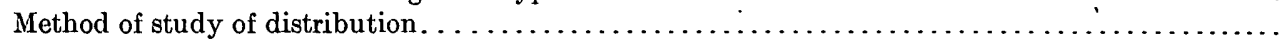

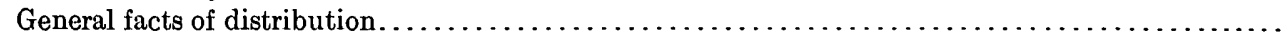

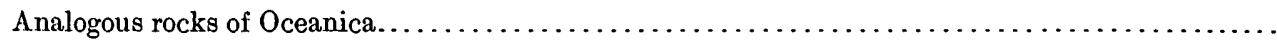

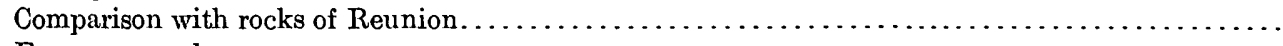

European analogues.

Theoretical bearings of data presented.

Geographic distinction between Atlantic and Pacific regions....

Reference of Hawaiian lavas to Alkalic or Calcic series.

Soda trachytes.

Kohalaite......

Rocks of Mauna Ken

Rocks of Division V.

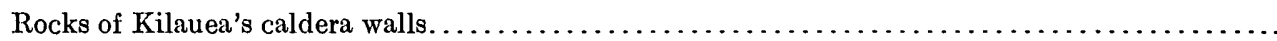

Basalts of Oahu.

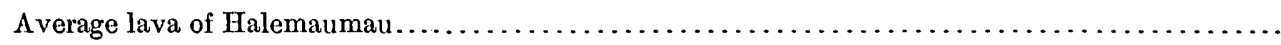

Basalts of Kauai. ................

Femic basalts near Honolulu.

Picritic basalts of Mauna La and Haleakala

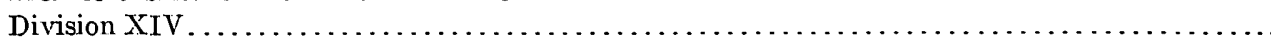

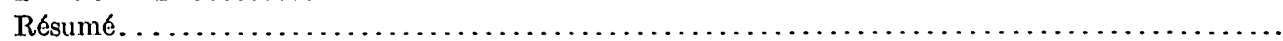

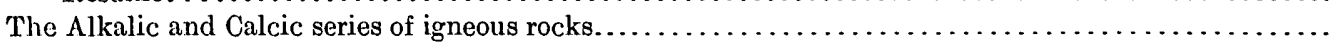

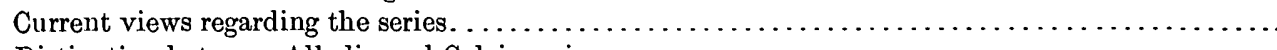

Distinction between Alkalic and Calcic series. . . . $\ldots \ldots \ldots \ldots \ldots \ldots \ldots \ldots \ldots \ldots \ldots \ldots \ldots \ldots \ldots \ldots \ldots$

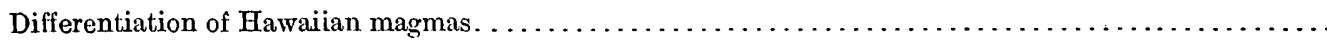

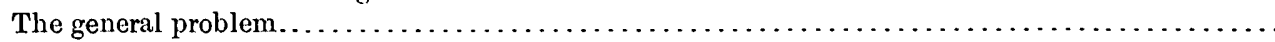

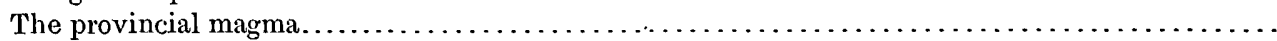

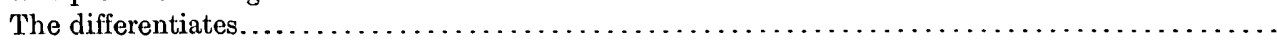

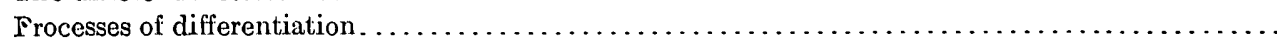

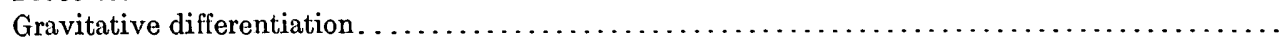

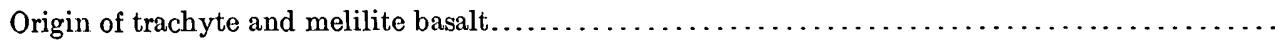

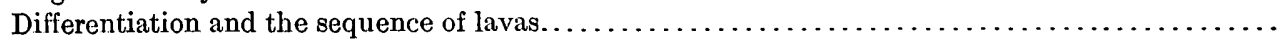

General course of differentiation. 


\section{ILLUSTRATIONS.}

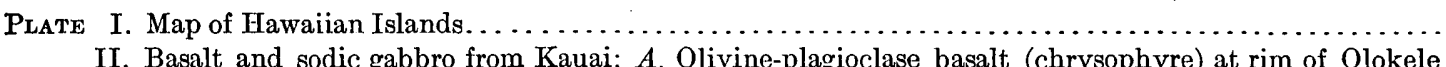

II. Basalt and sodic gabbro from Kauai: $A$, Olivine-plagioclase basalt (chrysophyre) at rim of Olokele
Canyon; $B$, Sodic gabbro (kauaiite) of Waiale Canyon.

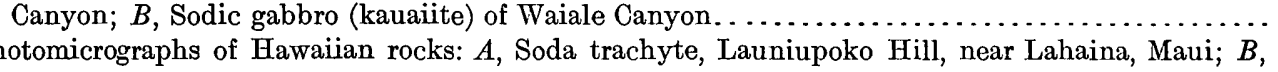

Nephelite-melilite basalt, near Honolulu, Oahu . . . . . . . . . . . . .

IV. Diagram to illustrate variation in normative composition of Hawaiian lavas...................

Page.

\section{INSERT.}

Normative ratio ard symbols... 


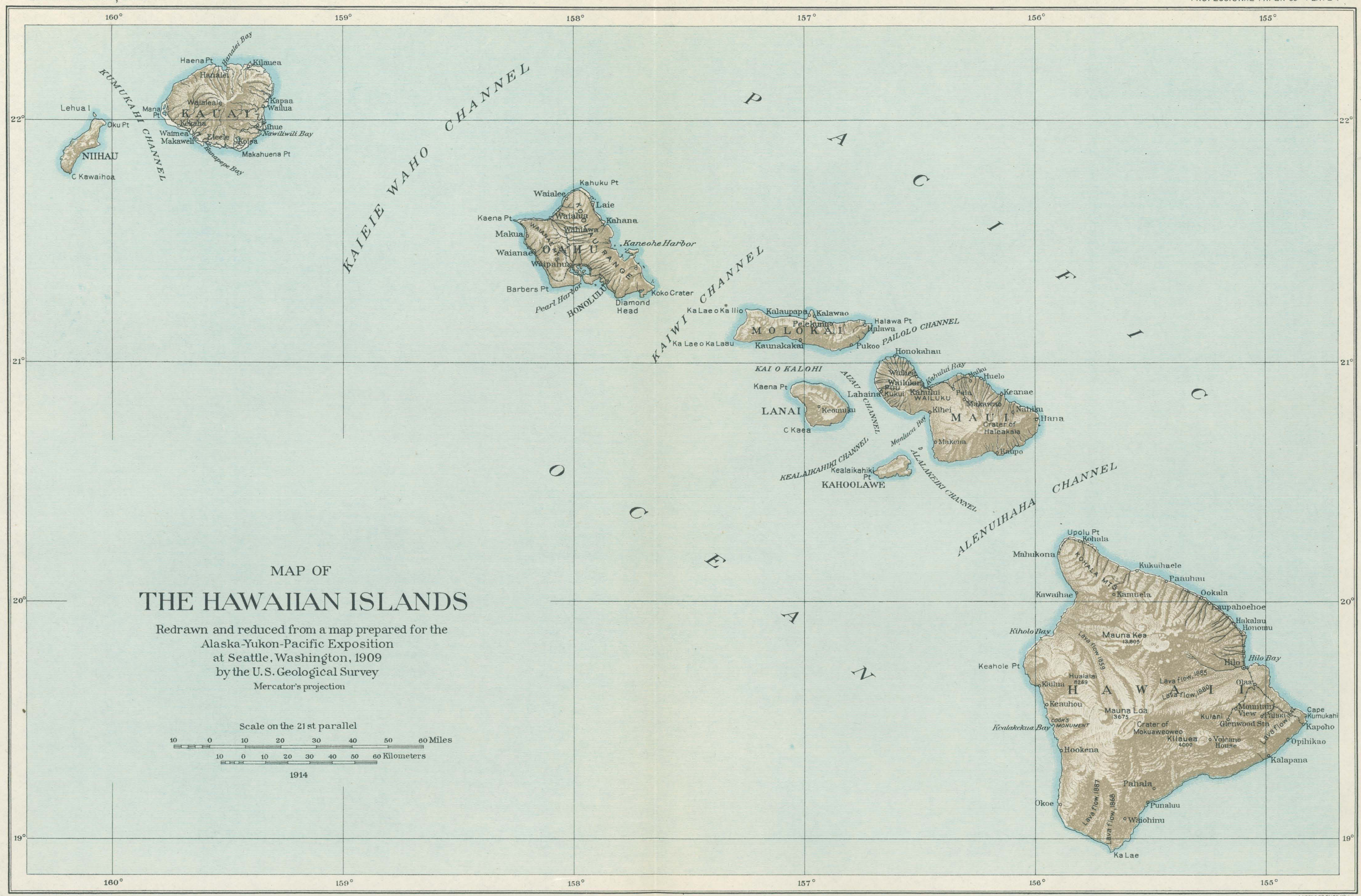




\title{
LAVAS OF HAWAII AND THEIR RELATIONS.
}

\author{
By Whitman Cross. \\ INTRODUCTION.
}

In 1902 I made a reconnaissance of certain parts of the Hawaiian Islands for the United States Geological Survey, with the hope of adding to the meager petrographic knowledge of this volcanic group. Although many geologists have visited these islands, interest has attached largely to the volcanic phenomena, and there is a singular dearth of important petrographic literature concerning the lavas themselves. The reason for this dearth I did not appreciate until I had visited the islands.

The lavas of Hawaii are generally referred to as basaltic. Many of them are plainly so, containing olivine and augite in prominent crystals. By far the larger number of the rocks are, however, chiefly black and aphanitic and seemingly of few varieties. The collector, be he layman or petrographer, is unfortunately likely to assume that they are all basaltic and to limit his collection to a few marked varieties. The truth is that there is a very considerable range in composition in the lavas of Hawaii, and systematic study will add many types to those now known. It will be highly desirable, however, to determine the rocks during the progress of field work, so that the types of unusual character may be traced out whenever found.

Among the rocks collected by me are a number of types that are rare or not mentioned in the literature of Hawaiian lavas, but for most of these types I am unable to give data of distribution, because their unusual character was seldom recognized in the field. As it now seems probable that more thorough investigation of the islands may be undertaken, it appears desirable to give such petrographic data as the collection of 1902 affords so that they may be of some rssistrnce to future workers.

An occurrence of trachyte on the island of Hawaii, first observed in 1902, has already been described. ${ }^{1}$

Besides describing rocks I collected myself I shall briefly review the scattered data of earlier literature concerning Hawaiian lavas, in order to provide a basis for a preliminary discussion of the provincial characters of these rocks, especially with relation to their chemistry and mineralogy. The Flawaiian magmas, imperfect as present knowledge concerning them may be, throw light on several interesting petrographic problems of the day.

The principal petrographic descriptions of Hawaiian lavas are those by E. Cohen (1880), O. Silvestri (1888), E. S. Dana (1889), and F. Möhle (1902). None of the rocks described were collected by the petrographers describing them, and only a part of one collection, that studied by E. S. Dana, was obtained by a geologist. Most of the lavas studied by Cohen were collected by Dr. William Hillebrand, a botanist, the father of Dr. W. F. Hillebrand, who analyzed some of the rocks to be described. Silvestri's material was gathered by Prof. P. Tacchini, an astronomer. Möhle's studies pertain to a collection made by Prof. H. Schauinsland, a zoologist. Under these circumstances there is naturally a lack of precise information concerning the local source and manner of occurrence of many interesting types, and much of the material is of value only in a general survey of the petrology of the islands.

It is an accepted generalization concerning the Hawaiian Islands that they have been built up by a long-continued series of volcanic eruptions beginning at a point far, west of the principal islands of to-day. Hawaii, the largest and most recent island, with its active volcanoes, is at the southeastern extreme of the row of island centers of eruption. 
Whether the earliest eruptions began at many points at about the same time, as J. D. Dana supposed, or whether the oldest center is at the northwest limit of the chain, is a question not entirely settled, it seems to me. The oldest volcanoes known are now represented by islets or mere reefs of basalt rising but a few feet above the sea. Possibly the earliest volcanoes of this chain have wholly disappeared through cataclysmic disturbances or long-continued erosion, such as has greatly reduced the bulk of even the more recent islands.

With this long history of volcanism along one line of weakness in the ocean bottom it is of interest to study the series of lavas of each center and compare those of different centers. For this reason, as well as for convenience, the rocks will be taken up beginning with those of the older centers and proceeding, in order, to those of Hawaii.

I have had access to other important collections besides the rocks obtained by myself. A large collection of lavas from Oahu, made by Prof. C. H. Hitchcock for the National Museum, and a small collection from Mauna Kea, made by E. D. Preston, were generously placed at my disposal by Dr. G. P. Merrill, curator of the department of geology in the museum. Dr. Merrill has himself described the Preston material. ${ }^{1}$ I am further indebted to the courtesy of Prof. E.S. Dana for an opportunity to examine the thin sections of Hawaiian lavas described by him. $\mathrm{He}$ also kindly furnished material for a chemical analysis of a soda trachyte from Maui.

\section{PUBLICATIONS CITED.}

For convenience the titles of publications cited are assembled in the subjoined list:

Brigham, W. T., The volcanoes of Kilauea and Mauna Loa: Bernice Pauahi Bishop Mus. Mem., vol. 2, No. 4, pp. $379-600,1909$.

Cockereix, T. D. A., Review of Manual of conchology, vol. 21, by Hyatt and Pilsbry: Science, new ser., vol. 37, pp. 255-257, 1913.

CoHEN, E., Über Laven von Hawaii, etc.: Neues Jahrb., vol. 2, pp. 23-62, 1880.

Cross, Whitman, An occurrence of trachyte on the island of Hawaii: Jour. Geology, vol. 12, pp. 510-523, 1904.

U. S. Geol. Survey, Geol. Atlas, La Plata folio (No. 60), 1899.

- Notes upon the Henry Mountain rocks (in Emmons, S. F., Geology and mining industry of Leadville, Colo.): U. S. Geol. Survey Mon. 12, pp. 359-362, 1886.

The laccolitic mountain groups of Calorado, Utah, and Arizona: U. S. Geol. Survey Fourteenth Ann. Rept., pt. 2, pp. 176-226, 1894.

Cross, Whitman, Iddings, J. P., Pirsson, L. V., and Washington, H. S., Modifications of the quantitative classification of igneous rocks: Jour. Geology, vol. 20, pp. 550-561, 1912.

DALY, R. A., Magmatic differentiation in Hawaii: Jour. Geology, vol. 19, pp. 289-316, 1911.

Origin of the alkaline rocks: Geol. Soc. America Bull., vol. 21, pp. 87-118, 1910.

The nature of volcanic action: Am. Acad. Arts and Sci. Proc., vol. 47, No. 3, pp. 47-122, 1911.

The differentiation of a secondary magma through gravitative adjustment: Festschrift Harry Rosenbusch, pp. 203-233, 1906.

DANA, E. S., Contributions to the petrography of the Sandwich Islands: Am. Jour. Sci., 3d ser., vol. 37, pp. 441-467, 1889 .

DANA, J. D., On the composition of the capillary volcanic glass of Kilauea, Hawaii, called Pele's hair: Am. Jour. Sci., 3 d ser., vol. 18, p. 134, 1879.

Characteristics of volcanoes, $399+$ viii pp., New York, 1890.

DAx, A. L., and ShepHerd, E. S., Water and volcanic activity: Geol. Soc. America Bull., vol. 24, pp. 573-606, $19 \mathrm{i3}$. Dutron, C. E., Hawaiian volcanoes: U. S. Geol. Survey Fourth Ann. Rept., pp. 75-219, 1884.

Harker, Alfred, Some aspects of modern petrography: British Assoc. Adv. Sci., Section C, Presidential address, Portsmouth, 1911.

The natural history of igneous rocks; I, Their geographical and chronological distribution: Science Progress, vol. 6, pp. 12-33, 1896.

- Natural history of igneous rocks, $384 \mathrm{pp}$., London, 1909.

Hiтснсоск, C. H., Geology of Oahu: Geol. Soc. America Bull., vol. 11, pp. 15-60, 1900.

Hawaii and its volcanoes, 2d ed., Honolulu, 1911.

IDdings, J. P., Igneous rocks, pt. 2, Description of igneous rocks, New York, 1913.

KLAUTSCH, A., Der jüngste Vulkanausbruch auf Savaii: K. preuss geol. Landesanstalt Jahrb., pp. 169-182, 1907.

Krukenberg, C. Fr. W.; Mikrographie der Glasbasalte von Hawaii, Inaug. Diss., Tübingen, 1877.

LAcroix, A., Les roches alcalines de Tahiti: Soc. géol. France Bull., 4th ser., vol. 10, pp. 91-124, 1910.

Sur la constitution minéralogique des volcans de l'île de La Réunion: Compt. Rend., vol. 155, pp. 538-544, 1913.

Lindgren, Waldemar, The water resources of Molokai, Hawaiian Islands: U. S. Geol. Survey Water-Supply Paper $77,1903$.

1 Merrill, G. P., U. S. Coast and Geodetic Survey Ann. Rept., 1893, pt. 2, appendix 12, pp. 630-632. 
LYONS, A. B., Chemical composition of Hawaiian soils and of the rocks from which they have been derived: Am. Iour. Sci., 4 th ser., vol. 2, pp. 421-429, 1896.

Merricl, G. P., Nepheline-melilite basalt from Oahu, Hawaiian Islands: Am. Geologist, vol. 25, pp. 312-313, 1900.

Möнts, F., Beitrag zur Petrographie der Sandwich- und Samoa-Inseln: Neues Jahrb., Peilage Band 15, pp. 66-104, 1902.

Philuips, A. H., A,recent analysis of Pele's hair and a stalagmite from the lava caves of Kilauea: Am. Jour. Sci., 3d ser., vol. 47, p. 493, 1894.

Pirsson, L. V., Petrography of Tripyramid Mountain: Am. Jour. Sci., 4th ser., vol. 31, pp. 428-429, 1911.

Preston, E. D., Determination of latitude, gravitation, and magnetic elements at stations in the Hawaiian Islands, otc.: U. S. Coast and Geodetic Survey Ann. Rept., 1393, pt. 2, appendix 12 (report by G. P. Merrill, pp. 630-632, no title).

Rosenutisch, FARry, Ėlemente der Gesteinslehre, 3d ed., Stuttgart, 1910.

- Mikroskopische Physiographie der massigen Gesteine, 4th ed., 1908.

Schalder, W. T., Notes on minerals from gabbro of Waimea Canyon, Hawaii: U. S. Geol. Survey Bull. 509, np. $85-87,1.1 .12$.

Suvvstri, O., Sopra alcune lave antiche e moderne del vulcano Kilauea nelle Isole Sandwich; Studi petrografici: Com. geol. Italia Boll., vol. 19, pp. 128-147, 168-196, 1888.

SMYTH, C. H., Jr., Chemical composition of the alkaline rocks and its significance as to their origin: Am. Jour. Sci., 4th ser., vol. 36, pp. 33-46, 1913.

STre.zNisn, A., [Note on melilite basalts]: Neues Jahrb., 1882, vol. 1, p. 229.

W Asfinciton, H. S., Chemical analyses of igneous rocks published from 1884 to 1900, etc.: U. S. Geol. Survey Prof. Paper 14, 1903.

WAshington, F. S., and Wriaht, F. E., A feldspar from Linosa and the existence of soda anorthite (carnegieite): Am. Jour. Sci., 4th ser., vol. 29, pp. 52-70, 1910.

Weber, M., Zur Petrograjhie der Samoa-Inseln: K. bayer. Akad. Wiss. math.-phys. Klasse Abh., vol. 24, pt. 2, pp. $287-3.10,1909$.

Wichmann, A., [Nephelin-Basalt von den Sandwich-Inseln]: Neues Jahrb., 1875, p. 172.

\section{PETROGRAPHY.}

\section{THE LESSER ISLANDS.}

Very little is known concerning the small islets lying northwest of Kauai. They are reported to consist of coral rock or sand with a foundation of basalt. The only petrographic details published are given by Möhle ${ }^{1}$ on the basis of Schauinsland's collection from Laysan and Necker islands. Laysan is about 800 miles northwest of Kauai. This island rises only 30 feet above the sea and consists superficially of coral limestone, but blocks of olivine-plagioclase basalt occur a little below sea level. This rock and two beach pebbles are represented in the collection. The pebbles differ in character, one being a decomposed basalt and the other a feldspathic rock with magnetite, little olivine, and rare augite grains. The latter rock has a trachytoid texture and is compared by Möhle with a soda trachyte from Maui, to be described in the present paper. The character of the feldspar of the Laysan rock is not stated, but it is no doubt a highly calcic plagioclase, as the rock is said to contain but 44.98 per cent silica.

Necker Island, 330 miles from Kauai, is 0.7 mile long and rises 300 feet above the sea. The principal rock of this island, according to Möhle, is an olivine-plagioclase basalt of holocrystalline porphyritic texture. Two dike rocks found on the island are also olivine-plagioclase basalts of doleritic texture, characterized by violet augite and ilmenite.

\section{ISLAND OF KAUAI.}

OCCURRENCE AND SOURCES OF MATERIAI STUDIED.

Kauai is the oldest of the larger islands of the Hawaiian group. It embraces about 547 square miles and has a general round outline. The island consists mainly of a single deeply dissected volcanic pile, the present summit of which, called Waialeale, has anelevation of 5,080 feet. From this center radiate deep canyons, the principal ones being on the north, west, and south sides. In the walls of these canyons and in the great sea cliffs of the northwestern shore are excellent exposures of the basaltic complex which, so far as known, makes up the entire island beneath the surficial materials.

The structure of Kauai is extremely simple and is typical of a basaltic volcano. All the canyons exhibit a series of dark basaltic flows dipping gently away from the general center of 
the island. The flows are diverse in thickness, their limits being clearly defined by breccia, scoria, or tuff zones, separating the more massive rock.

The rocks to be described were all collected by me and came from canyon branches of Waimea, Makaweli, and Hanapepe rivers, which head to the south or southwest of Waialeale and cut deep into its mass. Some of them came from lava flows, others from dikes, and still others from bowlders in the stream beds, selected to exhibit recognizable varieties which must occur in place in the upper parts of these valleys.

After the principal part of the erosion by which the strongly marked topographic features of Kauai were produced came minor volcanic outbursts at many places. By far the larger number of these comparatively recent eruptions were explosive in character, ashes being scattered over a large part of the island. Many of the best plantation soils of the lowlands are derived from these ashes. Small lava flows also issued from some of the recent vents.

The rocks collected embrace a considerable range of olivine-plagioclase basalts, olivine-free plagioclase basalt, limburgite, nepheline-melilite basalt, and gabbro, and they will be described under these heads.

\section{OLIVINE-PLAGIOCLASE BASALT.}

General characters.-The olivine-plagioclase basalts of Kauai exhibit a great range of textures. Many of them are dark, almost black rocks in which few, if any, mineral particles can be recognized by the unaided eye. Such aphanitic phases are either dense or variably vesicular. Some fine and nearly even-grained basalts contain many megascopically determinable particles of olivine, augite, and feldspar.

A porphyritic texture is not uncommon and is as a rule due to relatively large olivine phenocrysts. In some rocks olivine occurs in fine fresh crystals which exceed. 1 centimeter in diameter. The crystal form is often nearly perfect, but curved partings cause the phenocrysts to resemble perlitic grains. Rocks rich in large olivine phenocrysts are in many places also notably vesicular. Especially in such rocks the parting surfaces of olivine are likely to exhibit brilliant iridescent colors. The abundance and large size of the olivine phenocrysts are the most striking features of the basalts of Kauai that have been examined.

From the few specimens collected it appears that both olivine and plagioclase are quantitatively very variable constituents. Augite is always abundant, but titaniferous magnetite is decidedly more subordinate than is usual in such rocks. Olivine is likely to occur in abundant phenocrysts, but some of the aphanitic facies are also very rich in this mineral. Augite is commonly present in microscopic grains and even where it occurs in distinct crystals it is inconspicuous. Plagioclase is less prominent than the mafic ${ }^{1}$ silicates, occurring in the usual ophitic groundmass. It is as a rule more calcic than labradorite.

In general the plagioclase basalts of Kauai are, then, of common varieties. They are notably rich in titanic acid, which occurs in magnetite and in pink or purplish augite, but the total amount of the iron oxide is small.

Chemical composition.-The olivine-plagioclase basalts of Kauai are of varieties known in many parts of the world, but for the sake of comparison of different types and the general discussion of Hawaiian magmas two contrasting basaltic types were submitted to analysis, both from Olokele Canyon, the main branch of the Makaweli.

The composition of a nearly holocrystalline, minutely vesicular ash-gray olivine porphyry or chrysophyre, to use J. D. Dana's expressive field term, is shown by analysis 31 , in the accompanying table, made by W. T. Schaller. The rock occurs on the south side of Olokele Canyon, near tunnel 24 on the line of the Olokele ditch, which was in course of construction in 1902 .

Plate II, $A$, illustrates the texture of the specimen from which the material for analysis was taken. All the visible phenocrysts are olivine, of strong green color. They are almost perfectly fresh; some exceed 1 centimeter in diameter and none are as small as the augite in the groundmass. These olivine phenocrysts constitute from 20 to 25 per cent of the rock.

The vesicles are scarcely recognizable in the illustration. They are irregular in form and contain, as peculiar to them, only two or three recognized minerals. One of these occurs in

${ }^{1}$ Mafic is a modal term applied to the ferromagnesian minerals of rocks. The word femic, often used in this sense, applies properly only to normative molecules. 


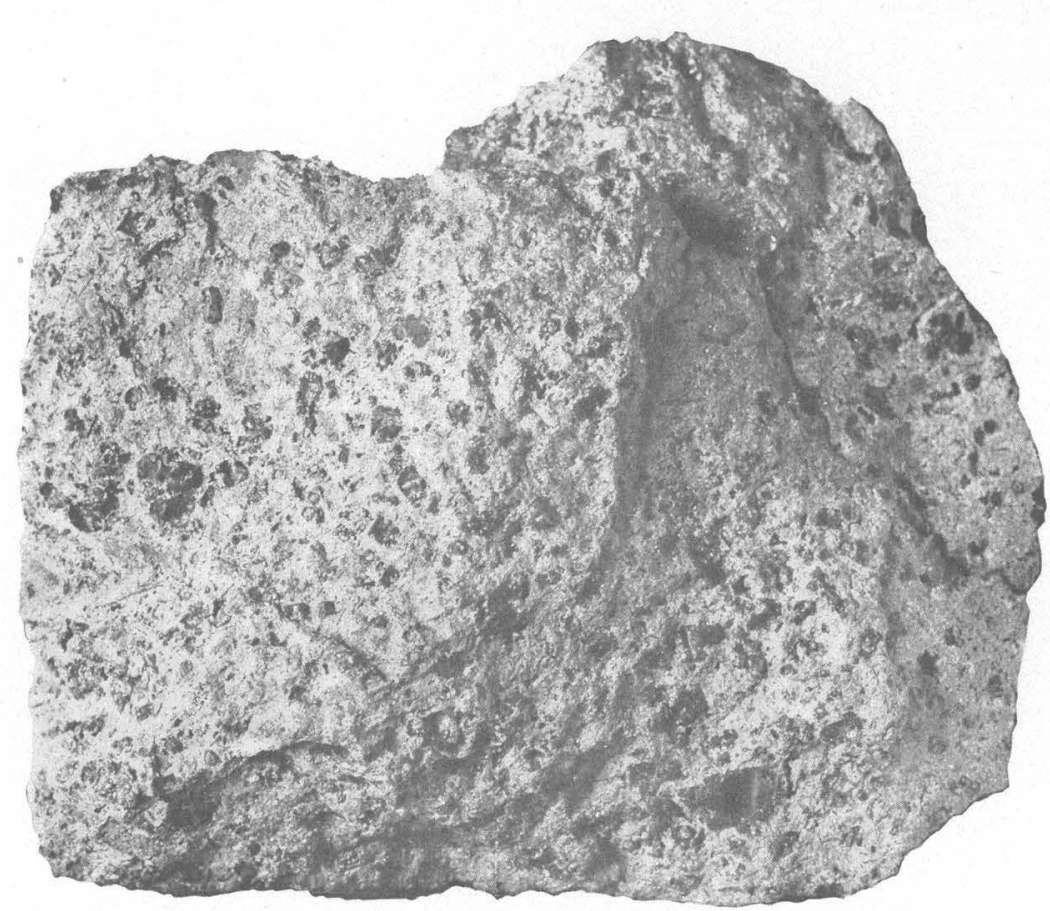

A. OLIVINE-PLAGIOCLASE BASALT (CHRYSOPHYRE) AT RIM OF OLOKELE CANYON.

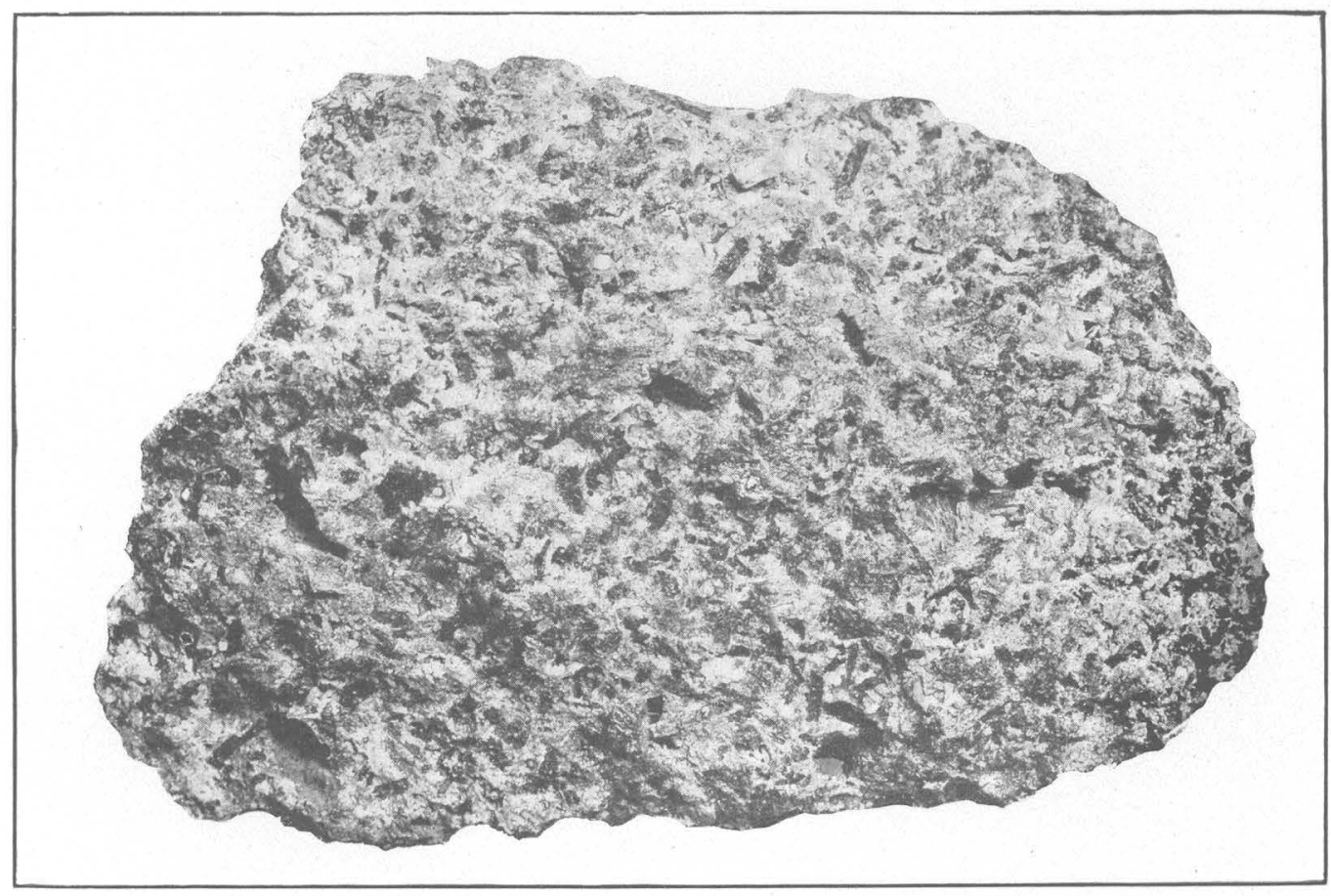

B. SODIC GABBRO (KAUAIITE) OF WAIALE CANYON.

BASALT AND SODIC GABBRO FROM KAUAI. 
minute dull-white rhombic dodecahedrons about 0.3 to 0.5 millimeter in diameter. These crystals are scattered all through the specimen, but rarely do more than two or three occur in one cavity. Detached crystals were examined under the microscope and found to be weakly doubly refracting. They do not extinguish as units but show a plaidlike pattern between crossed nicols, due to complex twinning. Through the assistance of $\mathrm{E}$. S. Larsen the index of refraction was determined to be $1.485 \pm 0.003$. This seemed to indicate either analcite or cristobalite. Fydrochloric acid does not attack the crystals.

For further identification of the mineral about 25 crystals, weighing in the aggregate about 1 milligram, were detached and their refractive index observed by Mr. Larsen. This material was then tested for water and silica by R. C. Wells, in the chemical laboratory of the Geological Survey. There was no loss on ignition, which, with the observed resistance to hydrochloric acid, makes it certain that the mineral can not be analcite. Ignition with hydrofluoric and sulphuric acids resulted in a loss of 85 per cent. The residue probably represents material on which these crystals were implanted. It thus appears almost certain that the mineral is cristobalite which has reverted from the original isotropic high-temperature form to the tetragonal modification existing below $175^{\circ}$.

Augite in minute anhedral grains and plagioclase in microlites make up the dominant groundmass, with augite in excess. The rock contains some smoky-brown intersertal glass but not as a continuous matrix. Magnetite occurs in minute very fresh grains, many of which are arranged in rows. It is presumably highly titaniferous. In many spots there is a distinct development of tridymite in wedge-shaped aggregates between plagioclase crystals, and characteristic round spherules of tridymite occur in some of the minute pores.

The rock of analysis 35 , made by $W$. F. Hillebrand, is nearly aphanitic, very dark gray, and belongs to a flow exposed at the south end of tunnel 20 on the Olokele ditch. Examination of it with a hand lens reveals numerous yellowish-brown olivine phenocrysts. In thin section it is found to consist of plagioclase, augite, olivine, and magnetite, with a little apatite and intersertal globulitic glass in disconnected areas. Both augite and plagioclase occur in larger individuals than in the chrysophyre described above. Olivine occurs chiefly in the phenocrysts but partly in anhedral grains like those of augite. Magnetite is concentrated in a few crystals equaling those of augite in size. The fabric is ophitic.

In the general discussion (p. 74) it is shown that these basalts are very near in composition to certain others from various parts of the world.

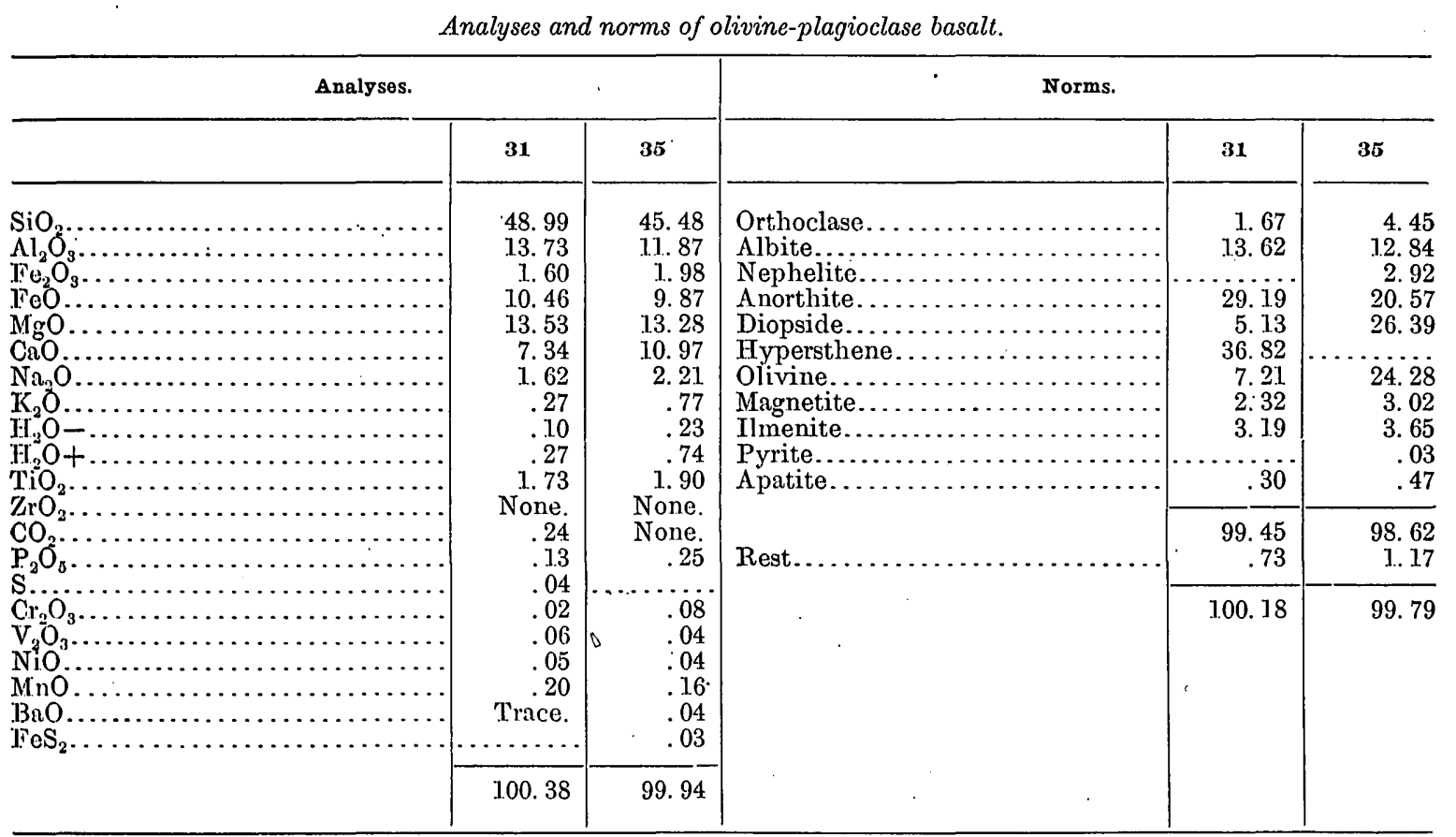


Quantitative classification.-The position and magmatic character of the basalt of analysis 31 in the quantitative system are shown below:

$$
\begin{aligned}
& \text { Class: } \frac{\mathrm{Sal}}{\mathrm{Fem}}=\frac{44.5}{55.0}=0.81=\mathrm{III} \text {, salfemane. } \\
& \text { Order: } \frac{\mathrm{L}+\mathrm{Q}}{\mathrm{F}}=\frac{0}{44.5}=0=5 \text {, gallare. } \\
& \text { Rang: } \frac{\mathrm{K}_{2} \mathrm{O}^{\prime}+\mathrm{Na}_{2} \mathrm{O}^{\prime}}{\mathrm{CaO}^{\prime}}=\frac{29}{105}=0.28=4 \text {, auvergnase. } \\
& \text { Subrang: } \frac{\mathrm{K}_{2} \mathrm{O}^{\prime}}{\mathrm{Na}_{2} \mathrm{O}^{\prime}}=\frac{3}{26}=0.11=4-5 \text {, auvergnose. }
\end{aligned}
$$

The rock of analysis 35 has the systematic characters expressed by the following data:

$$
\begin{aligned}
& \text { Class: } \frac{\mathrm{Sal}}{\mathrm{Fem}}=\frac{40.78}{57.84}=0.705=\mathrm{III}^{\prime} \text {, salfemane. } \\
& \text { Order: } \frac{\mathrm{L}}{\mathrm{F}}=\frac{2.92}{37.86}=0.08=5^{\prime} \text {, gallare. } \\
& \text { Symbol }{ }^{1}: \mathrm{III}^{\prime} .5^{\prime} .(3) 4.4-5 \text {. } \\
& \text { Rang: } \frac{\mathrm{K}_{2} \mathrm{O}^{\prime}+\mathrm{Na}_{2} \mathrm{O}^{\prime}}{\mathrm{CaO}^{\prime}}=\frac{43}{74}=0.58=(3) 4 \text {, camptonase-auvergnase. } \\
& \text { Subrang: } \frac{\mathrm{K}_{2} \mathrm{O}^{\prime}}{\mathrm{Na}_{2} \mathrm{O}^{\prime}}=\frac{8}{35}=0.23=4-5 \text {, camptonose-auvergnose. }
\end{aligned}
$$

This basalt is therefore in the division of the salfemanes, intermediate toward the dofemanes. It is transitional between the docalcic and alkalicalcic rangs and is therefore also transitional between the presodic subrangs, camptonose and auvergnose, of these rangs.

Relation of norm and mode in rocks analyzed.-These two rocks exhibit very notable differ-. ences in normative composition, but the analyses are by no means so strikingly different. The great variations in diopside, hypersthene, and olivine illustrate the cumulative effect of certain relatively small differences in silica, alumina, lime, and the alkalies. The normative diopside. of No. 35 is more than five times that of No. 31, because the decrease of alumina in No. 35 is coincident with increase of both lime and alkalies, doubly increasing the amount of lime available for diopside. The presence of hypersthene in No. 31 is due of course to the higher silica content.

The modal composition of No. 35 is clearly not far from the normative, but No. 31 exhibits a mode differing from the norm in a very interesting manner. According to the calculation of the norm this magma contained sufficient silica to have reduced the amount of the orthosilicate olivine to 7.21 per cent had there been that free exercise of the chemical affinities generally assumed to prevail in magmatic solutions. In the magma of basalt 35 conditions were evidently much more nearly normal. The augite of basalt 31 clearly contains a considerable amount of the normative hypersthene, but about half of the hypersthene is represented in modal olivine, freeing an amount of silica which appears in tridymite and cristobalite, as has been described.

These basalts of the same center of eruption and very nearly of the same age show the effect of some undetected difference in composition or in conditions attending their crystallization from magmatic solution, which is plainly of much importance. As will be brought out in the general discussion, there is some condition, commonly realized in Hawaii, which is particularly favorable to the formation of olivine from magmas whose silica is sufficient to have produced a much larger amount of a higher silicate than is found. This is commonly shown by the presence of free silica in olivine rocks, once considered an impossibility.

The differences between norm and mode of these rocks with regard to orthoclase and nephelite are not very striking quantitatively, and possibly the small amounts of these substances shown in the norms are hidden in the residual glass. In basalt 35, however, it seems more reasonable to suppose that nephelite and orthoclase are to some extent "occult molecules," to use the suggestive term proposed by Iddings "for material held in solid solution. It is well known that orthoclase may be and frequently is held in plagioclase. It has also been

\footnotetext{
1 In the symbols expressing the quantitativeclassification of a rock the use of a parenthesis shows that a rock falls in a narrow transitional zone between two divisions. A prime mark indicates a less marked approach to some adjacent division. For the limits of the transitional and inter-
} mediate zones the reader is referred to the original publication suggesting these distinctions (Jour. Geology, vol. 20, pp. 554-557, 1912). 
claimed by Washington and Wright ${ }^{1}$ that 5.5 per cent of carnegieite, having the stoichiometric composition of nephelite, is held in solid solution in labradorite of the island of Linosa. The norms of many rocks show normative nephelite where no trace of that mineral can be found in the rock, and a part at least of such potential nephelite may be explained in this way. Obviously no emphasis should be placed on this hypothesis until more evidence in its favor has been produced. Plagioclase is more abundant in the norm than it seems to be in the rock, but that may simply illustrate the difficulty of correctly estimating the amount of a transparent colorless mineral in such fine-grained aggregates.

\section{PLAGIOCLASE BaSAlt (POOR IN OLIVINE).}

Several rocks of Kauai are notably poor in olivine while rich in calcic plagioclase and augite and retaining the usual basaltic habit. Such rocks will be called basalts, although some of them may be referable to augite andesite. So long as it is unknown whether or not the paucity of olivine is characteristic of the whole mass represented by a given specimen, and the plagioclase is at least as calcic as labradorite, it seems best to recognize the affinities of these rocks with the basalts rather than with the andesites.

One of these plagioclase basalts occurs in the eastern part of the Koloa sugar plantation, in the southeastern part of the island, in low ground near the sea. It forms a low ridge west of a pumping station. In this vicinity are several centers of ash eruption and at least one lava flow of recent date; but the relations of the flows at the locality mentioned were not determined. It is surmised that they are younger than the main basaltic complex of the island.

This Koloa rock is gray in color and contains many small irregular pores, into which project crystals of feldspar. The pronounced ophitic fabric is visible megascopically through the cleavage planes of many narrow plagioclase tablets, but the interstitial augite can not be recognized. The plagioclase plates and prisms reach 2 to 3 millimeters in length.

In thin section the rock is seen to possess a not unusual type of ophitic fabric in that the plagioclase blades radiate in rude sheaves from many centers. Augite of common character lies between the feldspars and is developed in larger individuals than in any of the olivine basalts. Olivine is very sparingly present in grains similar to those of augite. The ore constituent appears in plates rather than in grains and is probably ilmenite. Residual areas of gray globulitic glass with very delicate plagioclase microlites are scattered through the rock.

A dense dike rock in the east fork of Waimea Canyon has much less olivine than the common types but more than the last-mentioned rock.

\section{LIMBURGITE.}

In the bed of Hanapepe River kelow the falls, about 7 miles from the sea, there are bowlders of typical dense aphanitic limburgite, associated with the usual predominant olivine-plagioclase basalts. There, as elsewhere, the actual quantitative relations of different rocks must be determined by future work. It is believed that the various flows exposed in the walls of Hanapepe Canyon are of olivine-plagioclase basalt, but unfortunately specimens were not collected to establish this fact. It is to be supposed that the waterworn bowlders of limburgite came from above the falls.

This limburgite consists of augite, olivine, magnetite, and a subordinate dark-brown globulitic glass. The minerals named are quite like those of the plagioclase-bearing basalts. No feldspar has been noted. The rock is thus clearly the nonfeldspathic extreme of the basaltic series of Kauai.

Added interest attaches to this rock from the numerous sharply angular inclusions of dunite and harzburgite contained in it. They range in the specimens collected from fragments 4 centimeters in diameter to minute grains. These xenoliths are granular in texture, are green or gray in color, and consist almost entirely of fresh olivine and pyroxenes, and of the latter enstatite is the most abundant variety. Some fragments are nearly pure olivine. Iron oxide particles are rare and no feldspar, biotite, or hornblende has been detected. 
This limburgite magma has thus brought up from some depth granular rocks of even simpler composition than its own. No other kinds of rocks were observed as inclusions in the limburgite. Similar xenoliths are present in certain basalts of Oahu, Molokai, and Hawaii, mentioned later.

Limburgite was also found with common basalts among bowlders of the bed of Waimea River above the mouth of Waialae River.

\section{OLIGOCLASE GABBRO, OR KAUAIITE.}

Occurrence.--In reporting the discovery of a coarsely granular rock, called "olivine diabase," in the west fork of Wailau Canyon, on the island of Molokai, Lindgren ${ }^{1}$ states that a piece of very similar rock was given to him with the assurance that it had been "broken from a large bowlder in one of the principal streams on Kauai." Through information given to me by Judge Hardy, of Lihue, and Mr. Francis Gay, of Kekupua, I found what I believe to be the bowlder from which the granular rock given to Mr. Lindgren was obtained. In the deep canyon of Waialae River, an eastern branch of the Waimea Canyon, there is a bowlder 12 feet long and 6 to 8 feet high and wide, known to the natives, according to Mr. Gay, as "the lightning stone." It is composed of rock like the specimen given to Mr. Lindgren, which I have examined.

The exact souree of this granular rock is unknown. From commanding positions on the ridge south of the canyon where the fragments occur no outcrops suggestive of a core were seen, but the jungle of tropical vegetation covering many of the slopes might well conceal a large body. The bowlders of granular rock occur in the stream bed below the "lightning stone" for about a quarter of a mile, to the junction with the main Waimea, and are also found in the detritus of the Waimea above the forks, although no fragment so coarse grained as the rock to be described was noted. For perhaps 100 yards above the "lightning stone" there are a few fragments in the stream gravels, but for several hundred yards still farther upstream no pebbles or bowlders of this granular rock were found. It thus seems likely that the ridge between the main Waimea and the Waialae contains a mass of the peculiar gabbroic rock here discussed.

The repeated statements of natives to $\mathrm{Mr}$. Gay, that this particular bowlder is often struck by lightning, is not borne out by fulgurites or other evidence noted. The upper part of the mass has a dark crust of weathering. On the sides it is gray in color and there are many round pits, an inch or two across and an inch deep, irregularly scattered over the surface. These pits resemble the beginning of drill holes, but they are believed to result from weathering action about miarolitic cavities.

Description.-The size and shape of the large bowlder made it impossible to obtain a hand specimen of it, but smaller ones near by afforded better opportunity. The specimen of which a chemical analysis was made is a granular porous rock (see Pl. II, $B$ ) of dark-gray color, exhibiting many irregularly disposed augite prisms somewhat less than 1 centimeter long and 3 millimeters thick. It contains many tablets of plagioclase, some nearly 1 centimeter in length, and still more abundant is a finer-grained pinkish-gray feldspathic mass in which augite and the larger crystals of plagioclase are embedded. Scattered through the mass are many irregular miarolitic cavities, of various sizes up to 1 centimeter or more. Crystals of augite, plagioclase, orthoclase, apatite, and magnetite project into these cavities, and some of the crystals show well-developed crystal planes.

W. T. Schaller ${ }^{2}$ has described crystals of orthoclase, apatite, and titaniferous augite found in these cavities. The augite exhibited eight determinable forms, two of which, belonging to the prismatic zone, are new.

The microscopic texture is irregularly granular. Small laths of calcic labradorite or bytownite penetrate both augite and olivine but are not abundant. The average or normative plagioclase, assuming all albite combined with anorthite and orthoclase as albite-free, is about $\mathrm{Ab}_{3} \mathrm{An}_{1}$. As developed in the rock there is perhaps the normative amount of orthoclase, namely, about 8 per cent. The dominant feldspar is plagioclase, most of the individuals of which have inner bands of labradorite and outer zones of highly sodic feldspar, probably anorthoclase. The 
labradorite portion is broader than the laths penetrating augite and exhibits albite, Carlsbad, and pericline twinning, the last very subordinate. The albite and Carlsbad twins indicate a highly calcic labradorite.

The zones of differing composition are commonly not symmetrically developed about a center, but consist of bands parallel to (010), and the gradation from labradorite to alkalic feldspar with index of refraction lower than balsam is rapid. Definite andesine and oligoclase bands have not been determined. Albite-twinning lamellæ are visible in the outer zones in places, but are not characteristic, while a mottled shadowy extinction is common. This sodic feldspar interlocks irregularly with other components.

The norm of this rock shows a little nephelite, but none has been found in the specimen analyzed, either microscopically or by chemical test. Sections of the coarser-grained "lightning stone" bowlder show crystals of apparent nephelite in small amount.

Olivine of a pale-yellowish tinge is present in a few crystals. The prominent augite has a pink or violet color, which testifies to its contents in titanic oxide. On borders it often exhibits agirite-nugite and in places distinct ægirite of strong green color, normal pleochroism, and orientation. Crystals projecting into cavities or interlocking with alkali feldspars most commonly exhibit this gradation to agirite.

Apatite, characterized by dustlike inclusions, is unusually abundant in large prisms. The norm shows that 5.0 per cent is present. Titanomagnetite is also a prominent constituent, the character being indicated by opaque rims of leucoxene about many crystals.

Chemical composition.- The moderately coarse grained rock to which the above description particularly applies and which is represented by Plate II, $B$, was analyzed by W. T. Schaller with the result given below. The notable features are low alumina, high lime, preponderance of soda over potash, and high phosphoric acid and titanium oxide. The influence of the chemical composition on the modal character of the rock is best shown by the calculation of the norm.

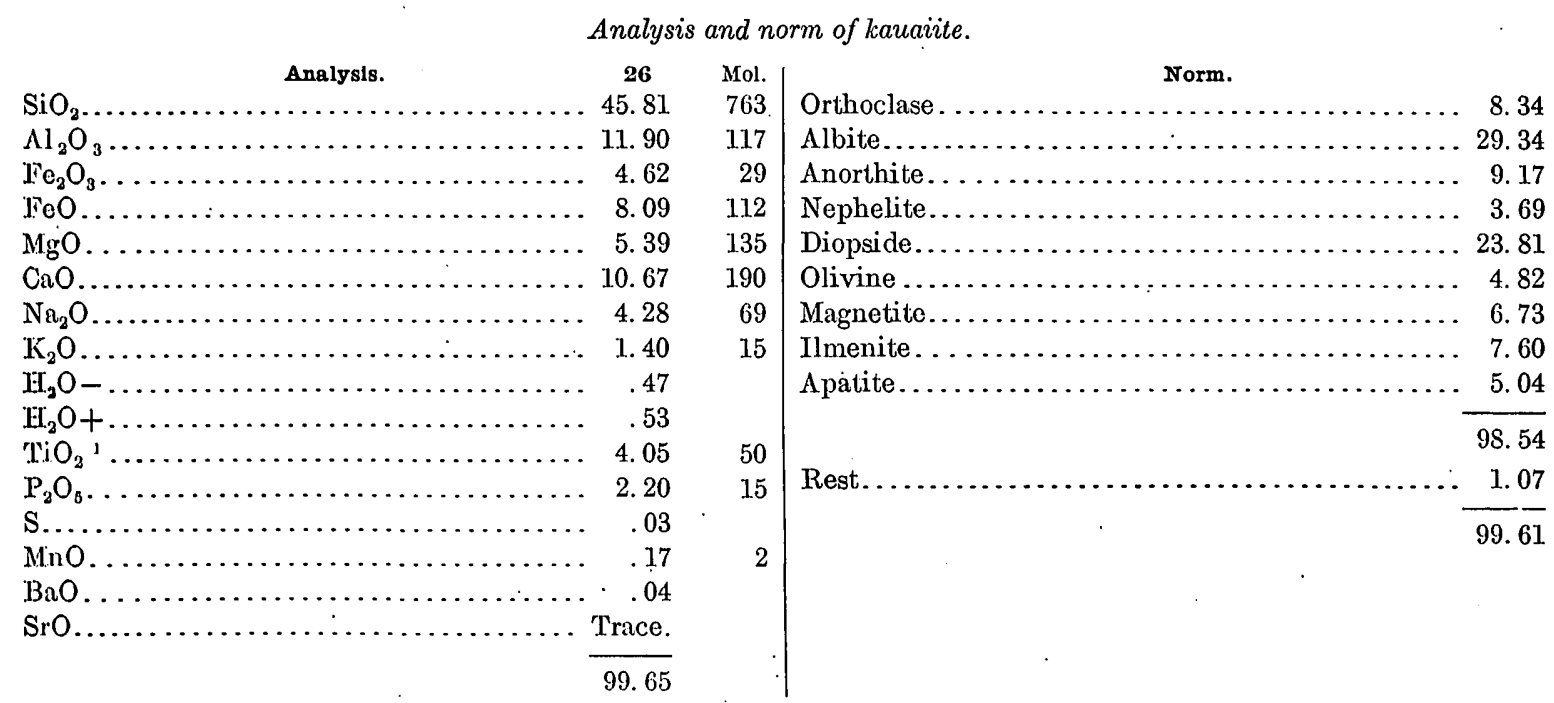

Quantitative classification.-Normative ratios showing the position of the rock in the quantitative system are as follows:

$$
\begin{aligned}
& \text { Class: } \frac{\mathrm{Sal}}{\mathrm{Fem}}=\frac{50.54}{4.0 .00}=1.05=\mathrm{III} \text {, salfemane. } \\
& \text { Order: } \frac{\mathrm{L}}{\mathrm{F}}=\frac{3.69}{46.85}=0.08=5 \text {, gallare. } \\
& \text { Rang: } \frac{\mathrm{K}_{2} \mathrm{O}^{\prime}+\mathrm{Na}_{2} \mathrm{O}^{\prime}}{\mathrm{CaO}^{\prime}}=\frac{84}{33}=2.55=2 \text {, kilauase. } \\
& \text { Subrang: } \frac{\mathrm{K}_{2} \mathrm{O}^{\prime}}{\mathrm{Na}_{2} \mathrm{O}^{\prime}}=\frac{15}{69}=0.22=4^{\prime} \text {, kilauose. }
\end{aligned}
$$$$
\text { Symbol: III. } 5^{\prime} .2 .4^{\prime} \text { 。 }
$$

\footnotetext{
$1 \mathrm{It}$ is thought by $\mathrm{Mr}$. Schaller that $\mathrm{Ti}_{2} \mathrm{O}_{3}$ may be present in small amount. $\mathrm{ZrO}_{2}, \mathrm{CO}_{2}, \mathrm{Cr}_{2} \mathrm{O}_{3}$, and $\mathrm{Li}_{2} \mathrm{O}$ were sought for but not detected.
} 
The low alumina content of this rock, in conjunction with rather high alkalies, brings it well within the domalkalic rang of the perfelic salfemanes. Clearly the lime must largely go to the augite.

Systematic relations and name kauaiite.-This sodic gabbro is most nearly related to the lavas of Kilauea among Hawaiian rocks. The basalts of the Olokele Canyon rim are far less alkalic in their feldspathic contents. The subrang kilauose is represented by few analyzed rocks, as a glance at Washington's Tables will show. Division VII of the table on page 70 gives analyses of the few close analogues found for this rock and the nearest allied lavas of Kilauea.

The rarity of analogous granular rocks shows that the Kauai type is not adequately characterized by calling it gabbro or augite diorite. With my concurrence, J. P. Iddings ${ }^{1}$ has applied the name kauaiite to "oligoclase-augite diorites" richer in salic constituents than the commoner andesine-bearing augite diorites, having reference to this rock as a chemical representative. Manifestly the magmas of this composition may vary considerably as to the composition of their plagioclase, one phase being the labradorite-anorthoclase development of the rock of Kauai.

\section{MELILITE-NEPHELITE BASALT.}

Occurrence.-Adjacent to the landing place for interisland boats on the north shore of Kilauea Bay, in northern Kauai, are ledges of black basalt overlain by tuffs. The basalt is rich in augite, olivine, nephelite, melilite, and magnetite and is best named melilite-nephelite basalt. On several accounts this rock deserves description, although the material at hand is scanty.

This basalt was observed only at and near the Kilauea Bay landing. It there forms a ledge a few yards thick, so far as noted. The overlying stratified basaltic tuff's form the principal part of a narrow headland separating Kilauea Bay from a nearly semicircular bay on the north, which is believed to occupy a portion of the crater of one of the numerous recent explosive vents that abound on Kauai. Bedded tuffs dipping south, west, or northwest from a point in the bay seem to indicate the position and size of the crater, more than half of which has been cut away, apparently by marine erosion. It is deemed probable that the flow of Kilauea Bay came from this center, but no specimens of the tuff were collected by which this relation might have been established.

Description.-The rock is dark gray and almost aphanitic, the only prominent element being white zeolitic aggregates filling minute pores. Examination with a hand lens reveals small crystals of olivine and suggests the actual holocrystalline character of the mass.

In thin sections olivine, augite, melilite, nephelite, and magnetite are found to be abundant constituents, in the order named. Apatite is also abundant and minute biotite flakes occur sparingly. All these minerals are nearly fresh and possess the characters common to them in basaltic rocks.

A rude microporphyritic texture is given to the rock by the size of some of the olivine crystals, but this texture is obscured by the serial gradation from the larger crystals to the smaller grains corresponding in size to those of the other constituents. The large olivines measure 1.5 millimeters in length and are more perfectly developed crystals than the smaller ones.

Melilite is next to olivine in size. It occurs in fresh tablets, the largest being 1 millimeter wide and 0.2 millimeter thick. The basal planes are not present and the crystals tend to the rude biconcave form characteristic of the mineral. Augite, magnetite, and nephelite penetrate the melilite substance. Cleavage parallel to the base is broken by many vertical partings. "Peg structure" is shown only in rudimentary form in a few crystals.

There is no glassy base. The original pores of the rock, of irregular shape, are surrounded by fresh crystals of nephelite, augite, magnetite, and apatite. The fine radiate, fibrous, zeolitic filling does not appear to be a product of decomposition of the surrounding rock.

Chemical composition.--An analysis of the rock by W. F. Hillebrand is given under No. 43 of the table on page 17. Under No. 43a is shown the analysis of that part of the rock soluble in dilute nitric acid $(1: 40)$. 
Analyses and norm of melilite-nephelite basalt.

\begin{tabular}{|c|c|c|c|c|}
\hline \multicolumn{3}{|l|}{ Analyses. } & \multicolumn{2}{|l|}{ Norm. } \\
\hline . & 4.3 & $43 a$ & & 4.3 \\
\hline \multirow{4}{*}{ 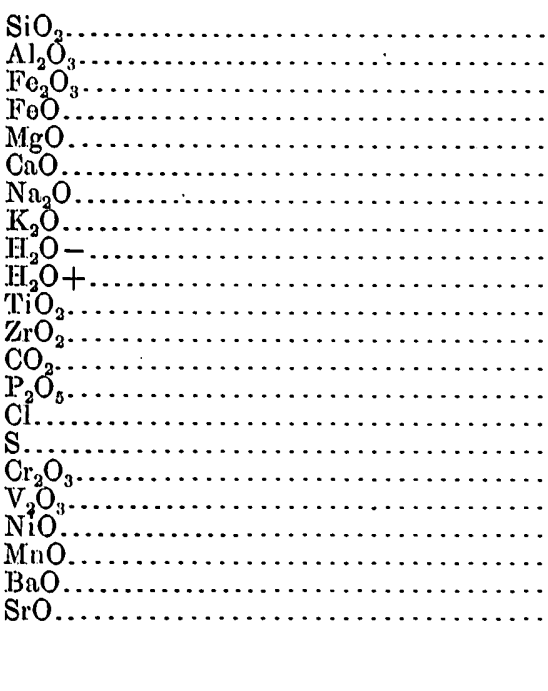 } & $\begin{array}{r}37.50 \\
9.12 \\
5.59 \\
8.81 \\
13.72 \\
13.85 \\
2.69 \\
.63 \\
1.05 \\
2.35 \\
3.21\end{array}$ & $\begin{array}{r}15.84 \\
7.68 \\
1.47 \\
.47 \\
3.39 \\
5.21 \\
2.28 \\
.60 \\
1.05 \\
2.35 \\
.05\end{array}$ & \multirow{4}{*}{ 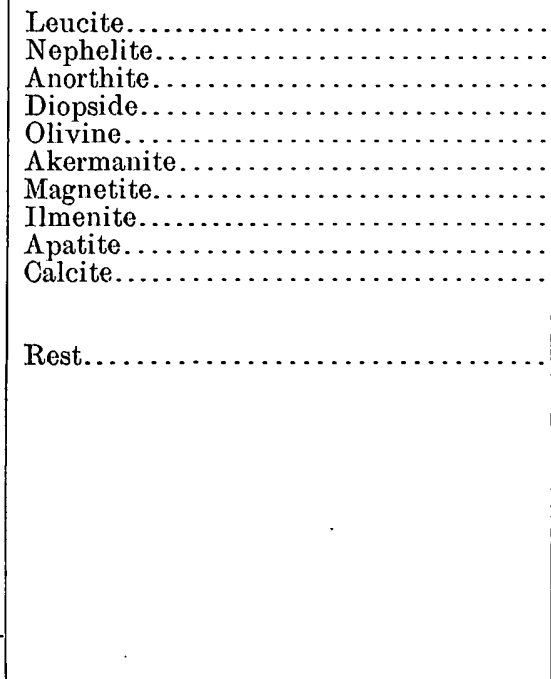 } & $\begin{array}{r}2.62 \\
12.21 \\
11.12 \\
31.04 \\
18.56 \\
3.92 \\
8.12 \\
6.08 \\
2.12 \\
.60 \\
\end{array}$ \\
\hline & $\begin{array}{l}.02 \\
.27 \\
.90\end{array}$ & $\begin{array}{l}.27 \\
.90\end{array}$ & & $\begin{array}{r}96.39 \\
3.68\end{array}$ \\
\hline & $\begin{array}{r}.05 \\
\text { Trace. } \\
.07 \\
.05 \\
.04 \\
.15 \\
.07 \\
.05\end{array}$ & .03 & & 99. 97 \\
\hline & 100.19 & 41. 59 & & \\
\hline
\end{tabular}

As shown in Division XIV of the table on page 77 this rock is similar in chemical composition to other melilite-bearing basalts of Texas, Baden, and Bavaria.

Quantitative classification.-The position of this rock in the quantitative system is shown by the ratios given below:

$$
\begin{aligned}
& \text { Class: } \frac{\mathrm{Sal}}{\mathrm{Fem}}=\frac{25.9}{69.9}=0.37=\mathrm{IV} \text {, dofemane. } \\
& \text { Order: } \frac{\mathrm{PO}}{\mathrm{M}}=\frac{53.7}{1.4 .2}=3.77=2 \text {, scotare. } \\
& \text { Suborder: } \frac{\mathrm{P}}{\mathrm{O}}=\frac{29.9}{23.8}=1.38=3 \text {, texiare. } \\
& \text { Rang: } \frac{\mathrm{MgO}+\mathrm{FeO}}{\mathrm{CaO}}=\frac{500}{202}=2.31=2 \text {, uvaldase. } \\
& \text { Subrang: } \frac{\mathrm{MgO}}{\mathrm{FeO}}=\frac{343}{157}=2.77=2 \text {, uvaldose. }
\end{aligned}
$$

BASALTS DESCRIBED BY MÖHLE.

The Schauinsland collection contains but three rocks from Kauai, and these are olivineplagioclase basalt, rich in olivine, from a locality given by Möhle ${ }^{1}$ as Tipukai, which may refer to an area called Kipukai, 3 or 4 miles southwest of Nawiliwili Bay.

\section{ISLAND OF OAHU.}

\section{INTRODUCTORY NOTE.}

The island of Oahu, upon which Honolulu is situated, embraces about 600 square miles. It lies about 70 miles southeast of Kauai and is the next younger island according to one idea of the history of the Hrwaiian group. Oahu is a volcanic doublet, exhibiting two main centers of eruption, represented now by two mountain ranges rather than by forms referable to great 
craters. The western range is called the Kaala and the eastern the Koolau, and each exhibits a great amount of denudation. The structure of each range is well shown in cliffs and gorges.

In Oahu, as in Kauai, the sculpturing of the older volcanic piles into mountains of about the present character was followed by a renewal of volcanic activity, resulting in many relatively small cinder cones and lava flows. Some of these, like the Punch Bowl and Diamond Head tuff cones, near Honolulu, are so little modified by erosion that they must be considered as very recent.

Although many geologists have visited Oahu, but few of its lavas have been closely studied and identified. In $1889 \mathrm{E}$. S. Dana ${ }^{1}$ gave petrographic descriptions of 12 massive lavas of Oahu. Most if not all of these came from the older eruptions of the island, and all are basalt, but they have variable olivine content, and Dana remarked as to a few specimens that "their highly feldspathic character and the microscopic structure made it seem as if they might more properly belong to the andesites."

In 1896 A. B. Lyons ${ }^{2}$ published analyses and brief descriptions of four rocks of Oahu, referring to them as basaltic lavas, but commenting on the abundance of feldspar in one of them.

The discovery of a nephelite-melilite basalt near Honolulu was announced by G. P. Merrill ${ }^{3}$ in 1900. This rock is described on pages 20-22.

These three publications embrace all the earlier definite determinations of the lavas of Oahu from known localities. C. H. Hitchcock ${ }^{4}$ in describing the geology of the island, calls the rocks basalts, with special reference to the prominent olivine in some of them. Other writers have been equally general and it seems to have been commonly assumed that nearly all the lavas must be of normal basaltic character.

In 1899 Hitchcock made a collection of the lavas of Oahu for the National Museum, and among them was the nephelite-melilite basalt described by Merrill. Knowing of this collection I made little attempt to obtain further material from Oahu. Having been unable through pressure of other work to complete his petrographic study of the Hitchcock collection, Dr. Merrill has very generously placed these specimens, with thin sections, at my disposal, and they form the basis for the greater part of the discussion which is to follow concerning Oahu.

Prof. Hitchcock has supplemented the collection just mentioned by additional material gathered while this study was in progress, partly in response to my requests. I am therefore under direct obligation to him for material and information of much value.

RANGE OF LAVAS.

The known lavas of Oahu are perhaps all referable to the great basaltic group, but they exhibit notable varieties expressed by the following terms: Olivine-plagioclase basalt, bronzite basalt, plagioclase basalt (olivine free), nephelite basalt, nephelite-melilite basalt, tephrite, limburgite, and gabbro. All these varieties, except the las $\tilde{\imath}$, express notable chemical differences in the magmas.

\section{OLIVINE-PLAGIOCLASE BASALT.}

Basalts in which plagioclase, olivine, augite, and titaniferous magnetite are the only prominent minerals are not abundant in the Hitchcock collection. Twenty specimens may be thus described and they fall into three rather distinct groups. Most of them are normal in that all the silicates named are abundant, though in varying proportions. The small amount of plagioclase in three rocks produces a more basic type than the normal, and a marked decrease in olivine makes a third variety. Magnetite is not abundant in any of these lavas, and in some of them the amount is very small. Naturally the basalts exhibit many textural phases, as is usual in such rocks.

The normal basalts are widely distributed. Only two of them come from the Koolau Range, and these occur at the southeast extremity, one in the tract called Niu, northwest' of the cinder cone Koko Head, and the other in a spur of the range northeast of the cone.

${ }^{1}$ Am. Jour. Sci., 3d ser., vol. 37, pp. 466-467, 1889.

2 Idem, 4th ser., vol. 2, p. 424, 1896.
${ }^{3}$ Am. Geologist, vol. 25, p. 312, 1900.

4 Geol. Soc. America Bull., vol. 11, pp. 15-60, 1900. 
Five specimens come from the Kaala Range, but only two of these belong surely to flows, one in the Makua Cliffs and the other at the extreme north end of the range. The groundmass of the latter rock contrins a notable amount of biotite-a rare mineral in Hawaiian rocks. A specimen from the watershed ridge west of the military reservation has an unusual texture. It is rich in labradorite $\left(A b_{3} A n_{7}\right)$ tablets 0.5 centimeter long and has an ophitic groundmass with interstitial glass. It is also vesicular and resembles the rock near Hilo described farther on. The mode of occurrence is not stated. The other two rocks of this group occur as dikes, at Kaena Point and in Makua Cliffs, respectively. The former is so nearly granular that it may well be termed olivine diabase, the augite being developed in grains inclosing plagioclase.

Two typical basalts occur in low exposures north of Pearl Harbor-at Eva Church and on the east line of the Eva plantation, on the Government road. Possibly these belong to old flows of the Kaala center, but the fact that normal basalt occurs in the Kuna cone, at the south end of the Kaala Range, one of the recent group called by Hitchcock" the "Laeloa craters," seems to indicate a possible recent age for the lowland rocks mentioned.

The recent center of eruption in the low country east of Honolulu, called Kaimuki or Telegraph Hill, is characterized by normal basalt represented by four specimens in the Hitchcock collection. Maumae, a crater cone lying a little north of Kaimuki, is likewise a center of recent eruption of normal basalt.

Two specimens of common basalt from East Koko Head, a tuff cone at the extreme southeast point of Oahu, may represent the lavas of the Koolau series of flows, as Hitchcock states that these older rocks are exposed beneath the tuffs of the cone.

The feldspathic basalt poor in olivine came from a quarry at the east end of Judd Street, at the south extremity of the spur between Pauoa and Nuuanu valleys, Honolulu. It is a minutely vesicular rock from a flow of the pahoehoe type and may belong to the Koolau flows.

The basalts poor in plagioclase but rich in olivine and augite come from recent eruptions east of Honolulu. One of them occurs as a dike in the tuffs of Diamond Head and the other represents a recent lava flow at the point called Kupikipikio, just east of Diamond Head.

BRONZTTE-BEARING BASALT.

Basalts of the usual habit and composition, except that olivine is to some extent replaced by a rhombic pyroxene, are widely distributed in Oahu. The relative proportions of olivine and bronzite-as the pyroxene may best be called-differ greatly in the rocks examined. Some are rich in both minerals, others carry both in small amount, in some olivine strongly predominates, and in others bronzite appears to the exclusion of olivine.

The rhombic pyroxene is often colorless, with faint pleochroism, and must be less rich in iron than hypersthene. It occurs only in prismatic phenocrysts, so far as observed, and plays throughout a rôle like that of olivine.

These rocks are apparently more abundant than the normal basalts in the Koolau Range. Sixteen specimens in the original Hitchcock collection come from the following localities in that range: (1) Niu, near Koko Head, (2) Manoa Valley, (3) Kalihi valleys, (4) east base of Tantalus, (5) spur between Manor and Nuuanu valleys (several specimens), (6) the Pali, (7) Waialua Plain, (8) Waimer Gulch, on railroad, (9) cliffs back of Kahuku plantation, (10) cliff at Laie Point. These localities are distributed from the southeast to the northwest extremity of the range.

The later collection made by Hitchcock shows that bronzite-bearing basalts are common near Honolulu. Several specimens were obtained near the polo grounds, in Moanalua.

From the Kara Range but three specimens were obtained-one from a dike in the Makua Cliffs, one from Kaena Point, where it is cut by the dike of ophitic texture above referred to, and one from the highest point in the valley between the Kaala and Koolau ranges, nearer to the Kaala.

The other bronzite basalts occur as fragments in the tuffs of Makalapa and Oliamanu, two of the recent cinder cones near Pearl Harbor. They probably represent old lavas of

i Geol. Soc. America Bull., vol. 11, p. 36, 1900. 
the Koolau Volcano. It is noteworthy that this rock was not found among the products of recent eruptions near Honolulu.

The Dana collection embraces 12 basalts of Oahu, and all belong apparently to the lavas of the older centers. In 11 of these rocks an almost colorless rhombic pyroxene occurs in variable amount. These rocks came from Moanalua, Punaluu, Kahuku, and the Waialua Plain, the first three localities belonging to the Koolau center, while the last is between the two mountain ranges of the island. Dana ${ }^{1}$ specially refers to two highly chrysophyric rocks, and these serve admirably to illustrate the variations in composition and possibly the genetic relations of several phases of these lavas.

A chrysophyre of Kahuku Head contains an extraordinary amount of olivine in prominent phenocrysts. Dana estimates the olivine as probably two-thirds of the mass. Nearly all the phenocrysts are olivine, with rare comparable ones of bronzite. The groundmass is in its composition and texture nearly a counterpart of many of the finer-grained lavas of Oahu, which contain microphenocrysts of bronzite in a mass of augite, plagioclase, and magnetite. Olivine is rare or lacking in the latter rocks and, as Dana pointed out, they approach pyroxene andesites very closely in composition.

A rock of Waialua Plain contains augite and bronzite associated with the dominant olivine phenocrysts and also some corresponding labradorite crystals. The groundmass is here also similar to some of the olivine-poor lavas.

In general these olivine-poor bronzite basalts of Oahu seem similar in composition to the Mesozoic olivine weisselbergite of Rosenbusch ${ }^{2}$ where bronzite and olivine play the same rôle, replacing each other with slight differences in chemical composition of the rock, especially as to silica. Weisselbergite is classed by Rosenbusch with the andesites (augite porphyrites).

PLAGioclase BASALT (OLIVINE-FREE).

Several basalts of the Hitchcock collection consist almost wholly of augite, labradorite, magnetite, and a small amount of apatite. Olivine is rare or absent. These rocks are aphanitic and contain no notable phenocrysts of any kind. In both composition and texture they correspond to the groundmass portion of some of the normal basalts. Labradorite is older than the augite, which occurs in small grains between the feldspars and not in large chadocrysts inclosing them. No doubt the rocks of this group exhibit in some occurrences a development of augite and labradorite phenocrysts and other textural variations not showm in the specimens at hand.

Nine specimens belonging to this group have been examined. Four of them occur at the Pali gap in the Koolau Range. Two at least occur as dikes; the others are not specified as to whether flows or dikes. It is a natural suggestion that these rocks belong not to the older series of Koolau lavas but to the comparatively recent eruptions of this locality noted both by Hitchcock and by me.

Four other rocks free from or very poor in olivine occur in ledges on the Oahu plantation, in the broad, low valley between the Kaala and Koolau ranges and 2 or 3 miles north of the recent vents adjacent to Pearl Harbor. Presumably these rocks are exposed in the walls of channels cut through the soil, etc., by streams from the Koolau Range, but the source of the lavas may not be determinable. In all these rocks an insignificant amount of olivine or bronzite, or both, occurs in very small phenocrysts or in anhedra like those of augite.

\section{NEPHELITE-MELILITE BASALT.}

Occurrence.-The existence of the nephelite and melilite bearing basalt of Oahu was first announced by Wichmann ${ }^{3}$ in 1875 on examination of ballast rock brought by a ship to Hamburg. The source of the material was said to be Oahu, but the exact locality was not known. Cohen ${ }^{4}$ later studied some of these ballast fragments and confirmed Wichmann's statements as to 
nephelite and melilite, and Stelzner ${ }^{1}$ completed the identification of the melilite. Möhle ${ }^{2}$ refers to a melilite-nephelite basalt from the vicinity of Honolulu.

The rock collected by Hitchcock and described by Merrill ${ }^{3}$ in 1900 appears to be the first nephelite-melilite basalt from Oahu of which the occurrence is known. I visited the locality from which the rock described by Merrill was obtained. It is so unusual a type as to warrant further microscopical and chemical study and description.

The Schauinsland collection described by Möhle contrined one specimen of nephelite-melilite basalt from Oahu, but as the locality is indefinite, being "aus der Umgebung von Honolulu," it is uncertrin whether this rock belongs with one of the occurrences to be described or not.

The rock described by Merrill as "nepheline-melilite basalt" and further discussed below occurs in a quarry near Moiliili Church, about midway between Punch Bowl and Diamond Head, in the eastern suburbs of Honolulu. The small outcrops are surrounded by alluvium, and the source of the lava stream which the rock represents is not definitely known. Hitchcock $^{4}$ says of this occurrence:

It is surmised that this rock came from Rocky Hill, as there is a slope from the crater to the quarry and to the church. There are several masses of cinders interrupting the continuity of the basalt, which are suggestive of blowholes and steam vents. Amygdaloidal and zeolitic minerals occur at the quarry. Phacolite and laumontite have been identified among them. Calcite and amorphous silica are also present, the latter on surfaces several square feet in extent in rudely.parallel lines. The bluff is traversed by small veins full of nephelite, granular melilite, and augite. Either of these minerals may form a layer of crystals, closely crowded together, all standing vertically to the plane of occurrence. Veins 3 inches wide or less abound in these minerals, mixed with a multitude of acicular crystals of kaliophilite. Mr. Wirt Tassin has identified these species.

In the Hitchcock collection there are many specimens from the Moiliili quarry and also of similar rock from the following localities: (1) At and near Rocky Hill, Manoa Valley, (2) Kalihi Valley, north edge, (3) Gulick Stream, west of Kamehameha School, Honolulu, (4) half a mile east of Bishop Museum.

Rock from quarry near Moiliili. Church.-The specimens from the quarry near Moiliili Church exhibit some textural differences, but on the whole a marked uniformity. I will first describe the type analyzed, collected by me.

This rock is megascopically a gray massive trap of millimeter grain, the holocrystalline character of which is suggested by numerous glistening crystal or cleavage faces of unrecognizable minerals. The hand lens reveals a large amount of light-colored minerals. No phenocrysts can be observed. There are some small irregular cavities lined with a thin zeolitic crust. The constituents are olivine, augite, melilite, nephelite, magnetite, and apatite, all but the apatite being abundant. All the minerals are very fresh, and the absence of iron hydroxide and other stains makes recognition of almost every particle possible.

Olivine occurs in colorless, nearly euhedral prismatic crystals reaching a maximum size of 1.5 millimeters. It is nearly free from inclusions, and much of it exhibits no alteration. It seems to form about one-fifth of the rock, as found also in the norm.

Augite is less abundant than olivine and less prominent, for it occurs in anhedrons interlocking most irregularly with other minerals and in some places being the oikocryst or matrix crystal of the poikilitic fabric. Its major diameter seldom exceeds 0.6 millimeter. The augite has the reddish or yellowish-brown pleochroic colors of titaniferous varieties but not very. strongly.

Melilite appears in the usual basal tablets, presenting most commonly long rectangular outlines. The prism faces are much sharper than the basal, interlocking with nephelite and magnetite in particular being common on the basal sides. The melilite is fresh, without "peg structure" in the rock analyzed, has a few marked basal cleavage planes, and seldom contains inclusions. It is colorless and of pale-bluish or milky polarization color in thin sections. The substance of last deposition in the outer basal zones, between particles of other minerals, is 
often of higher double refringence than the central zone, appearing yellowish in polarized light. The melilite forms about 15 per cent of the rock.

$\therefore$ Nephelite is developed in very sharply defined euhedral or subhedral grains, few of which exceed 0.1 millimeter in diameter in the rock analyzed. It includes magnetite and apatite especially but is penetrated by all other minerals. It is fresh and has a very slightly higher refractive index than Canada balsam. It forms nearly or quite one-quarter of the rock.

Magnetite occurs abundantly in subhedral crystals and groups, nearly as large as the nephelite. It gives no special indication of titanium content, but a test of powder separable with the magnet gave 13.4 per cent $\mathrm{TiO}_{2}$. No perofskite was noted, but Merrill reports that mineral as present. Apatite is developed in minute long prisms.

A photomicrograph of this rock is given in Plate III, $B$.

The Hitchcock collection shows that the rock of the Moiliili quarry varies little in composition and texture. Olivine has less tendency to phenocrystic development in some specimens. Augite often appears more markedly as an irregular oikocryst, inclosing nephelite and magnetite, but in some of the rock it is found only in small roundish grains. In the coarsestgrained specimens nephelite and a part of the magnetite reach a diameter of 1 millimeter and the texture is nearly equigranular.

The analysis, by George Steiger, and the calculated norm of this rock are given below:

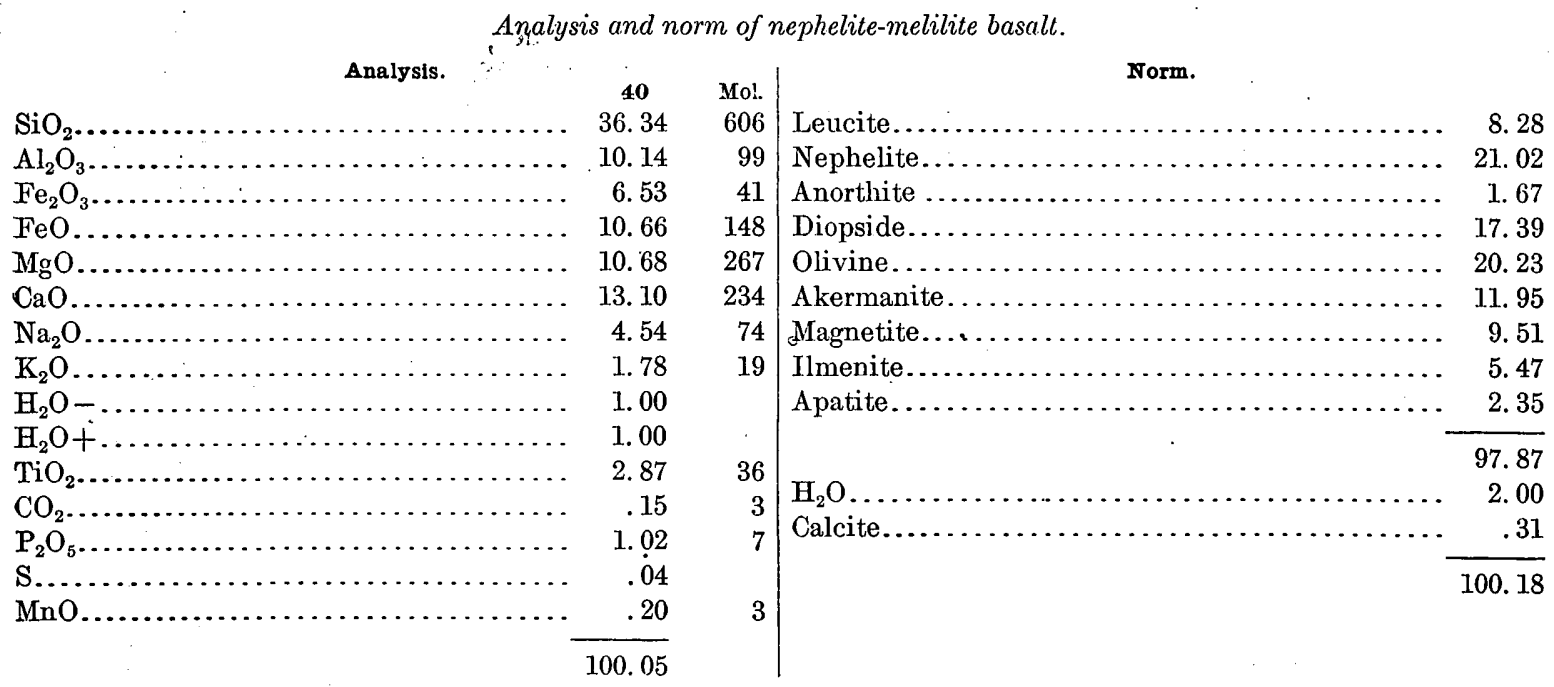

Quantitative classification.-The position of this rock in the quantitative system is shown by the ratios given below:

$$
\begin{aligned}
& \text { Class: } \frac{\mathrm{Sal}}{\mathrm{Fem}}=\frac{30.97}{66.90}=0.46=\mathrm{IV} \text {, dofemane. } \\
& \text { Order: } \frac{\mathrm{P}+\mathrm{O}}{\mathrm{M}}=\frac{49.57}{14.98}=3.10=2 \text {, scotare. } \\
& \text { Section: } \frac{\mathrm{P}}{\mathrm{O}}=\frac{17.39}{32.18}=0.54=(3) 4 \text { (unnamed). } \\
& \text { Rang: } \frac{(\mathrm{FeMg}) \mathrm{O}}{6 \mathrm{aO} \prime}=\frac{418}{225}=1.86=2(3) \text {, casselase. } \\
& \text { Subrang: } \frac{\mathrm{MgO}}{\mathrm{FeO}}=\frac{267}{151}=1.77=2(3), \text { casselose. }
\end{aligned}
$$

Symbol: 'IV.2.(3) $4.2(3) .2(3)$.

The rock thus falls in casselose but is transitional in several respects. The rang and subrang to which it is transitional are unnamed as yet, but through its near approach to section 3 of order 2, texiare, it becomes also transitional to uvaldose, a subrang containing the nephelitemelilite basalt of Kauai and the picritic basalt of Haleakala. The relation of this rock to other melilite basalts is brought out in Division XII of the table on page 75. It is certainly significant that the "black sand" or ash, so abundant about Honolulu, has a marked resemblance to this basalt of the Moiliili quarry in composition, as is also illustrated in Division XII. 


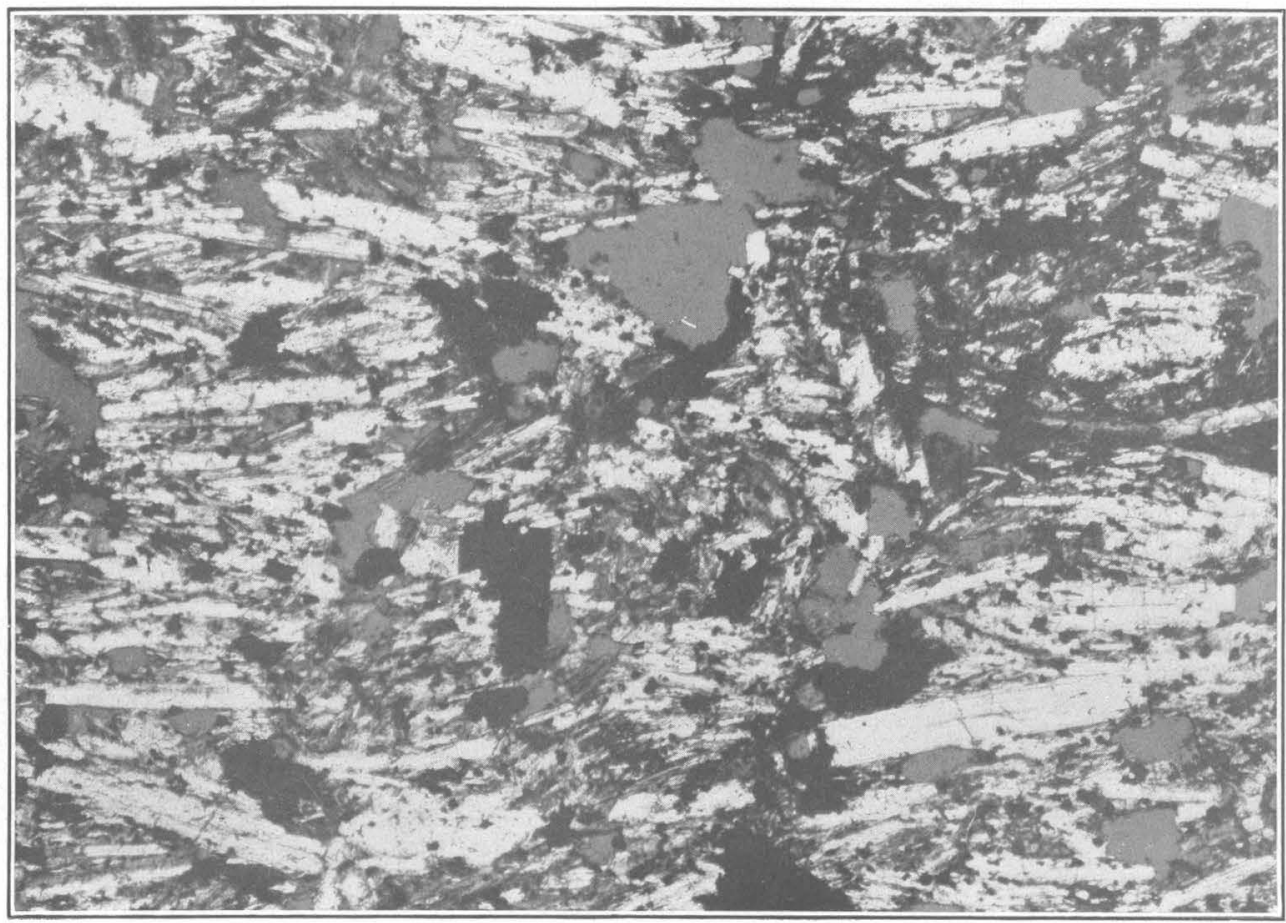

A. SODA TRACHYTE, LAUNIUPOKO HILL, NEAR LAHAINA, MAUI.

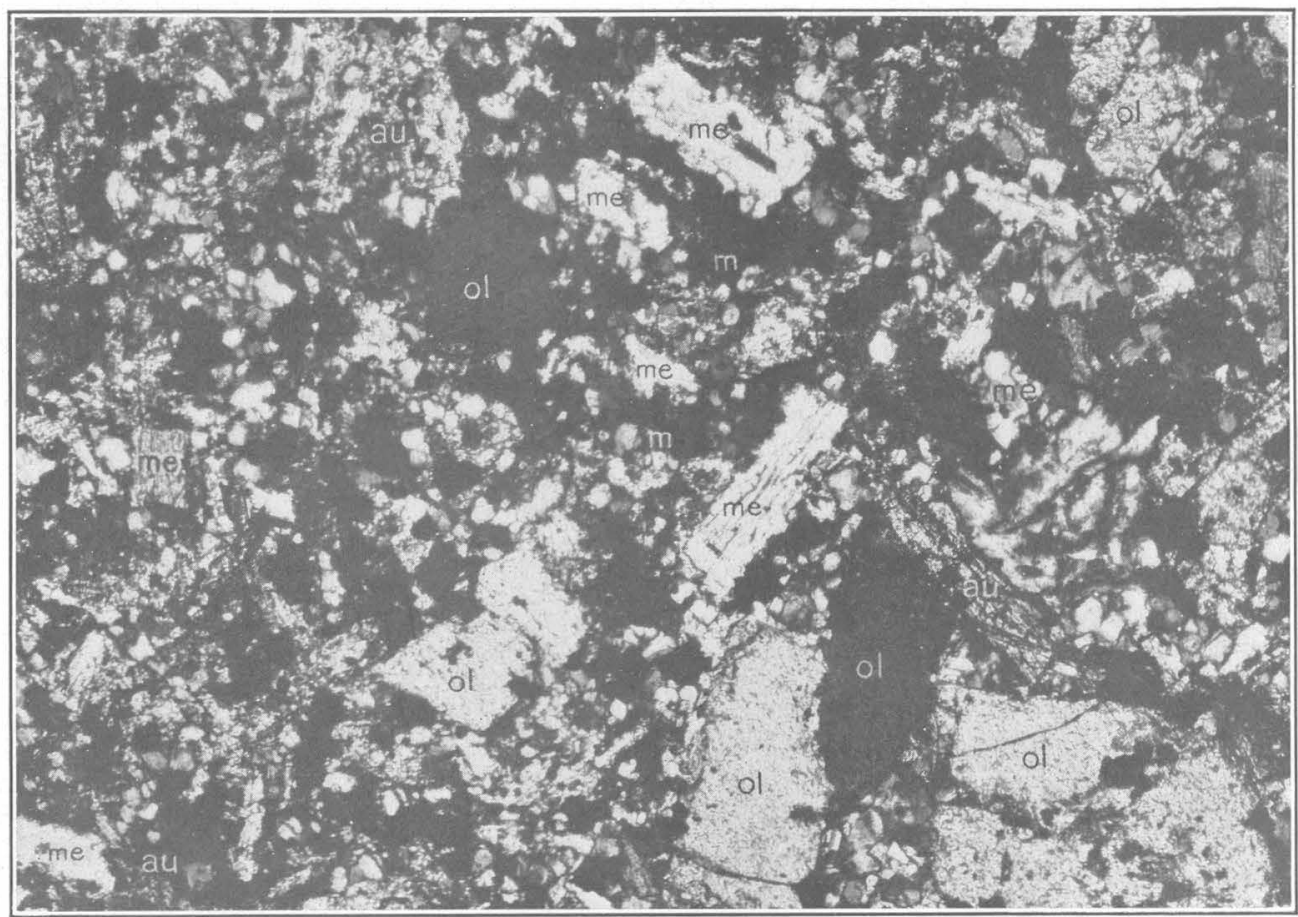

B. NEPHELITE-MELILITE BASALT, NEAR HONOLULU, OAHU.

au $=$ augite, $m=$ magnetite, $m e=$ melilite, ol =olivine.

PHOTOMICROGRAPHS OF HAWAIIAN ROCKS. 
NEPHELITE BASALT AND ALLIED ROCKS.

In the Hitchcock collection are several rocks which in the current nomenclature must be called nephelite basalts, although this name unduly emphasizes a very subordinate constituent. It is probable, I think, that these lavas, like the melilite-bearing and other extreme types, are of recent origin and local occurrence, but so little is known of the actual field occurrence and relations of these rather obscure rocks that extended description is scarcely desirable at present.

In general, these rocks are rich in augite, olivine, and magnetite. They are all aphanitic, and as a rule olivine is the only phenocryst. The dominant and of ten obscure mass of augite and magnetite is very fine grained and in some places there is a small amount of residual glass. Olivine probably takes some part in this almost unresolvable mixture.

The nephelite occurs in mostly anhedral specks penetrated by augite and magnetite. Its habit is the same as in the finer grained of the melilite basalts and identification rests on this fact, with the close agreement of its index of refraction with that of balsam and the weak birefringence. In one specimen an alkali-rich feldspar is associated with the nephelite in small amount.

Among the localities for nephelite basalt is the Punch Bowl, near Honolulu-probably from a dike; another is Kapuai, one of the Laeloa craters; ${ }^{1}$ a third is one of the Salt Lake craters; and a fourth is a dike in the Pali, 750 feet below the road pass, on the east side. Möhle ${ }^{2}$ found a nephelite basalt in the Schauinsland collection, from some locality near Honolulu.

Allied rocks which may be called nephelite basanite occur at Diamond Head (dike?) and Kapolei, a crater of the Laeloa group. The specimens representing them are very dense basic rocks deserving further study on better material.

The rock of one of the dikes in the Pali, near the road, is perhaps best named a limburgite.

\section{BASALTIO TUFFS AND ASHES OF RECENT ERUPTIONS.}

From a review of all available data it appears that most if not all of the tuff cones and craters of comparatively recent age on Oahu represent eruptions of lavas more basic than normal basalt. The melilite and nephelite bearing rocks and other varieties described above seem the common products of these centers.

The tuft's themselves have seldom been described. In the Schauinsland collection Möhle ${ }^{3}$ found palagonite tuff from the Punch Bowl and more normal basaltic tuff from the vicinity of Pearl Harbor and from the Salt Lake craters. Lyons ${ }^{4}$ has analyzed several lime and magnesia rich hydrated tuffs of Punch Bowl, Diamond Head, and other localities.

Fitchcock ${ }^{5}$ has given valuable data concerning the general character of many of these recent centers of eruption near Honolulu, under the heading "Secondary craters," but without petrographic determinations. Although the Hitchcock collection contains many specimens of tuff and fragments, most of them are much altered or otherwise unsuited to be taken as representative of the cones from which they came. The petrographic nature of the eruptions from a given center can be'satisfactorily determined only by careful field studies made by a petrographer.

The occurrence of the peculiar "black ash," a volcanic sand of notable homogeneity forming a deposit over a large area about Honolulu, has been examined by Hitchcock ${ }^{6}$ with much care. Fis conclusion is that it originated in Punch Bowl, Tantalus, and a third crater. Lyons's analysis of the ash ${ }^{7}$ bears so close a resemblance to that of the nephelite-melilite basalt of the Moiliili quarry that I have included it in the collection of igneous-rock analyses (No. 37, p. 48), believing that it represents a particular magma. It seems possible that this ash and the Moiliili flow of basalt came from the same center, or at least that they are contemporaneous eruptions.

It is noteworthy that these two rocks contain much more potash than the other basic rocks of the islands, and it is reported by chemists of the agricultural experiment station near

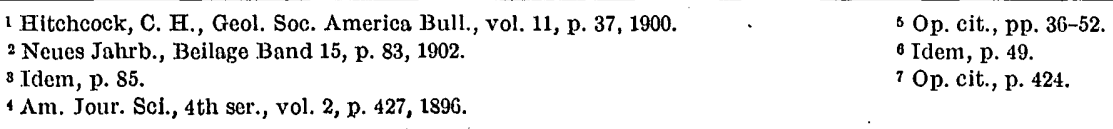


Honolulu that much of the volcanic ash in the lowlands of Oahu is rich in potash. In fact, a Honolulu newspaper quotes E. V. Wilcox, of the experiment station laboratory, as saying that some ashes analyzed have 7 per cent of potash.

From a petrographer's standpoint it would be singular to find an ash anywhere in Hawaii which is richer in potash than in soda. But the rocks just mentioned show such unusual richness in potash that the possibility of still richer ones must be acknowledged. If highly potassic tuffs or ash beds occur in the islands it is to be hoped that their petrographic relations may be determined and their source established.

\section{ISLAND OF MOLOKAI.}

ROCKS DESCRIBED BY MÖHLE.

The principal contribution to the petrography of Molokai is the description by F. Möhle ${ }^{1}$ of about 50 specimens of massive rock collected by Schauinsland. These specimens are said by Möhle to come from points scattered all over the island, but he gives details of locality for only a few of them. A large part of the material came from the Pali, a cliff facing the leper settlement on the north coast, and represents lavas of the great eastern volcanic center, which Dana ${ }^{2}$ regarded as having been divided by a fault running near the north coast, the Pali being considered as practically a fault scarp.

The lavas of Molokai are said by Möhle to be of typical basaltic character, consisting of plagioclase, augite, olivine, and magnetite, but there is much variation in the quantitative relations of these constituents and he accordingly distinguishes three groups, which are connected by intermediate rocks. First and most abundant are types characterized as normal olivine-bearing basalts, with the qualification that the olivine content is not high; second come rocks in which olivine is rare or, in six specimens, entirely lacking; third, and contrasting with the second group, there are rocks in which olivine is abundant and augite rare or lacking.

The so-called normal basalts are generally porphyritic, with tabular phenocrysts of labradorite and prisms of augite or rhombic pyroxene, the latter in two rocks only. Olivine appears to be decidedly subordinate for a normal basalt, and in his conclusion that these rocks are basalts rather than andesites Möhle seems to be influenced mainly by the silica contents, which he found in three lavas to be $48.21,46.47$, and 45.11 per cent.

The augite-free basalts are said to have an abundant colorless glass base, and biotite occurs in one of them. They are compared to lavas from Hawaii described by Cohen, to which reference will be made.

An aphanitic aphyric rock from Kalae is called "Nephelinbasanitoid" by Möhle. Besides predominant feldspar, augite, olivine, and magnetite, there are a few crystals of nephelite in this rock. Tests with hydrochloric acid are thought to have confirmed the optical identification of nephelite. The locality called Kalae is said to be in the interior of the island, at about 500 meters above the sea. I have not been able to find the name on any map of Molokai.

The rocks of this island appear to deserve much more detailed description than is given them by Möhle, and chemical investigation is specially to be desired. It seems probable that many of the lavas are nearer to trachydolerite or pyroxene andesite than to typical olivineplagioclase basalt.

\section{ROCKS DESCRIBED BY LINDGREN.}

In his paper on the water resources of Molokai Lindgren gives but little space to the petrography. He refers to the lavas observed ${ }^{3}$ as chiefly "normal feldspar basalt, somewhat glassy, and with olivine, occasionally also containing phenocrysts of soda-lime feldspars."

We are indebted to Lindgren for the very interesting discovery of coarsely granular "olivine diabase" in the west fork of Wailau Gulch, which penetrates to the heart of the mountains of eastern Molokai. The bed of the west fork contains many bowlders of this rock, which are thought by Lindgren to come from a large crosscutting body near the head of the gulch. The 
diabase was not found in place and is not present in the east fork of the gulch. As described by Lindgren, ${ }^{1}$ this interesting rock is composed of very calcic plagioclase, near anorthite, with augite, magnetite, and olivine, the last named being in much smaller quantity than the augite. By comparison of Lindgren's specimens with the sodic gabbro of Kauai they are seen to be very similar, even to the violet color of the augite.

\section{ISLAND OF MAUI.}

Maui, the next to the youngest island of the Hawaiian group, embraces about 728 square miles. It is a volcanic doublet, like Oahu, and the two mountainous parts, which are of unequal size, are known as West and East Maui. The older of these is West Maui, a huge volcanic pile some 25 miles north and south by half as much east and west. The highest central point is Puu Kukui, which has an elevation of 5,788 feet, according to the old Government map. From the vicinity of this peak valleys and ridges radiate. The deepest canyons are on the east and north sides.

Although in the main West Maui is appanently a great volcano long dead and deeply dissected by erosion, there are, as in Kauai and Oahu, numerous small comparatively modern lava and tuff cones or craters distributed over the scarred flanks of the old giant, from sea level nearly to the summit. Lava flows from some of these recent vents no doubt cover portions of the slopes in practical conformity with much older flows.

East Maui has for its central feature the great volcano of Haleakala, the irregular crater of which has often been described This enormous volcanic pile has also been deeply scored on the windward side, but many canyons appear to have been filled up, wholly or in part, by lava floods from recent vents not yet clearly identified. Still later than these flows there are, as on West Maui, many cinder and lava cones of so recent formation that their slopes have been little modified by denudation.

\section{West Maui.}

So far as I am aware, no specimens definitely representing the old central complex of West Maui have ever been described by a petrographer. I examined with some care the bowlders occurring in the stream beds of the Iao and Waihee valleys at the road crossings of these rivers near Wailuku, on the east coast. The heads of these valleys are tremendous crater-like gorges cut deep into the core of the volcano under Puu Kukui and may be supposed to reveal the character of the deeper parts of complex more extensively than the other shallower valleys.

\section{BOWLDERS OF WAIHEE VALLEY.}

Dark fine-grained or aphanitic rocks predominate in the Waihee Valley, but there are few of distinct olivine-plagioclase basalt. Some bowlders exhibit olivine and augite phenocrysts and less abundant plagioclase.

Among the types collected is a porphyritic olivine-plagioclase basalt, which is less basic than the normal. It is a dull pinkish-gray rock with many small phenocrysts of labradorite ( 2 to 3 millimeters) and a few of olivine, embedded in a dominant aphanitic groundmass. The holocrystalline groundmass consists chiefly of andesine microlites, augite, olivine, and magnetite. The last three average about 0.1 millimeter in diameter. Orthoclase and possibly nephelite are present in subordinate amount. The rock differs from the basalts of Oahu in that labradorite rather than olivine is its dominant phenocryst and it contains a larger amount of alkali feldspar.

Another notable type among the Waihee bowlders is a dark-gray perpatic olivine aphanophyre. Some of the olivine phenocrysts are aggregates of several grains. The groundmass is holocrystalline and consists of augite, olivine, oligoclase or andesine microlites, and magnetite, with orthoclase and nephelite in small amount. The augite, olivine, and magnetite average about 0.01 millimeter in diameter, but the rock is so fresh that each grain is clearly defined.

1 Op. cit., p. 15. 
A third type is a black, perpatic labradorite aphanophyre, the phenocrysts of feldspar ranging from minute specks to crystals having a diameter of 3 millimeters. The groundmass is holocrystalline but extremely fine, equigranular, and made up of augite, olivine (?), magnetite, and a colorless mineral, all averaging about 0.01 millimeter in diameter. The colorless mineral is apparently alkali feldspar, or perhaps in part nephelite.

BOWLDERS OF IAO VALLEY

The rocks noted in Iao Valley resemble those of the. Waihee, the dark labradorite aphanophyre being common. Of particular interest is a millimeter-grained, equigranular olivine diabase of ophitic fabric and very simple composition. Olivine is much subordinate to both augite and labradorite in this rock. No orthoclase or quartz appear in the thin section. As Iao Valley heads directly under Puu Kukui this granular rock may belong to a core mass in the heart of the volcano.

ROCKS DESCRIBED BY MÖHLE.

Nearly all the rocks of the Schauinsland collection from Maui ${ }^{1}$ were obtained near Lahaina, on the west coast. Among them is a type called augite andesite by Möhle, which he considers to be probably the same as the highly feldspathic rock described by Dana-the rock here described as soda trachyte. A silica determination yielded 61.48 per cent, agreeing closely with the 61.63 per cent reported by Dana. Möhle adds that orthoclase is present in several large grains, the determination resting on the parallel extinction and lack of twinning. The texture is described as panidiomorphic trachytoid. Besides the predominant feldspars Möhle mentions only magnetite and a prismatic mineral of wine-yellow color, thought to be augite. No biotite, hornblende, or olivine were found.

Melilite-nephelite basalt was identified by Möhle in one specimen obtained near Lahaina. It is a gray porphyritic rock, in which many of the olivine phenocrysts are large interpenetration twins. Melilite is partly developed in phenocrysts. The groundmass of melilite, nephelite, augite, and magnetite is rather coarsely granular. Perofskite is absent. The rock is said to resemble the melilite basalt of the Schauinsland collection from the vicinity of Honolulu, Oahu.

Normal plagioclase basalt is, according to Möhle, the term best describing the other rocks collected near Lahaina, 20 in number. His description however, shows that olivine is not abundant in most of them, though a few are rich in that mineral. It seems quite possible that magmas of considerable range of normative composition are represented in this group of so-called normal basalts.

A gray fine-grained basalt from Wailuku is said by Möhle to have but little olivine. This must also belong to the lavas of West Maui.

SODA TRACHYTE NEAR LAHAINA.

Occurrence and character.-E. S. Dana ${ }^{2}$ described a rock of unusual character collected by the late S. E. Bishop from Launiupoko Hill and Mount Ball, near Lahaina. Dana quotes statements of Bishop concerning the occurrences of this rock to the effect that it seems to be a crumpled lava, whose fragments have disintegrated in part under the influence of weathering, leaving harder crustlike portions which in places assume grotesque forms. Launiupoko Hill is a cone shown on the map of West Maui as about 3 miles southeast of Lahaina. "Mount Ball," said to be " $2 \frac{1}{2}$ miles above Lahaina," does not appear under that name on the map. It may be the hill called Paupau, on the slope east of Lahaina.

The remarkable character of this rock was duly recognized by Dana and he planned further investigation of its occurrence and composition, which has, unfortunately, not proved feasible. Material from both of these occurrences has been given to me by Prof. Dana, for examination and comparison with the trachyte of Puu Waawaa. The rock of Mount Ball is a schistose, 
friable mass, easily crumbling between the fingers, and made up chiefly of silvery scalelike crystals of oligoclase. Dana described them as interpenetration twins on the Carlsbad law,

mostly arranged parallel to the brachypinacoid and hence showing no other kind of twinning. *** The extinction [on 0.10] makes an angle of a few degrees with the basal edge, varying + or - with a slight change in the direction of the section. This optical character and the further fact that the acute bisectrix is nearly normal to the brachypinacoid would make the feldspar an oligoclase.

Besides the oligoclase there is a little olivine in fragments of crystals and a little brown biotite. The silica of this rock was determined by Wheeler at 61.63 per cent.

The specimen from Launiupoko Hill is a gray compact-appearing rock containing many minute pores. It is not foliate like the rock of Mount Ball, but has, as seen under the microscope, a typical microlitic trachytic fabric with little tendency to a development of scales or flakes. The microlites are on the average 0.3 millimeter long and 0.02 millimeter wide. The fabric of this rock is illustrated by Plate III, $A$ (p. 22). The maximum refractive index of the microlites is about that of Canada balsam. Between the microlites is irregular anhedral alkali feldspar. with notably lower index.

The mafic constituents, which seem fairly prominent in the rock, as seen in thin sections, consist of minute irregular black specks and larger prismatic or irregular grains of brown or green color. The opaque specks, of dull metallic luster by reflected light, can not be magnetite, as the analysis shows only 0.07 per cent of $\mathrm{FeO}$. They do not exhibit the brilliant luster nor red color of hematite, and their character has not been determined.

The brown constituent is cloudy and appears to be partly limonitic, but part of it has homogeneous optical behavior and extinguishes nearly parallel to the apparent vertical axis. At the ends of these crystals project small green prisms of the same orientation, and a larger growth of the green mineral is common in the prismatic zone. Isolated green particles also occur. The larger the crystal the deeper the green color, and all optical behavior indicates agirite as the green mineral, while it is believed that the brown is acmite. If the analysis is correct these mafic elements are rich in $\mathrm{Fe}_{2} \mathrm{O}_{3}$, with $\mathrm{TiO}_{2}$ and $\mathrm{MnO}$ probably more abundant than $\mathrm{FeO}$. The femic molecules of the norm amount to but 7.50 per cent.

Among the analogues of this trachyte of which analyses are given in Division $I$ of the table (pp. 63-64) is a trachyte of Sardinia, of which Dr. Washington has kindly given me permission to publish his analysis in advance of his description of the rock. It is noteworthy that in that trachyte brown and green minerals occur, which are probably of the same character as those in the rock of Maui. In the Sardinian trachyte the $\mathrm{Fe}_{2} \mathrm{O}_{3}$ is also greatly in excess over $\mathrm{FeO}$.

Chemical composition.-The rock of Launiupoko Hill (Dana's No. 28) has the following composition, according to analysis by George Steiger. Its molecular ratios and norm are also given.

Analysis and norm of rock of Launiupoko Hill.

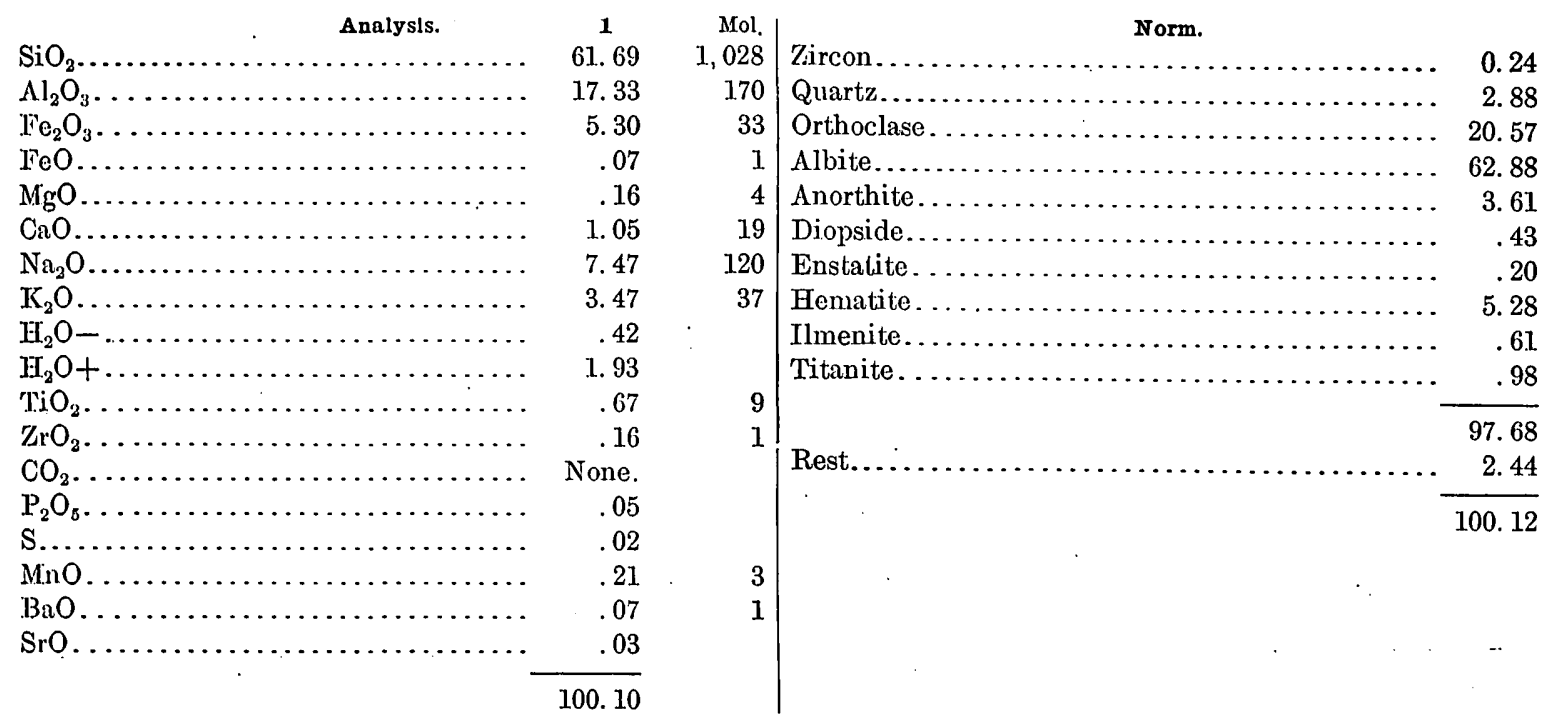


As analysis and norm indicate, this rock is a soda trachyte standing in composition very near the rock of Puu Waawaa, on Hawaii (p. 35), and, as Division I of the table (pp. 63-64) shows, its nearest analogues in chemical character are a tinguaite of Essex County, Mass., two acmite trachytes of the Crazy Mountains, Mont., a trachyte of Westerwald, in Hesse-Nassau, and the trachyte from Sardinia referred to above.

Quantitative classification-The position of the trachyte in the quantitative system is shown by the following data:

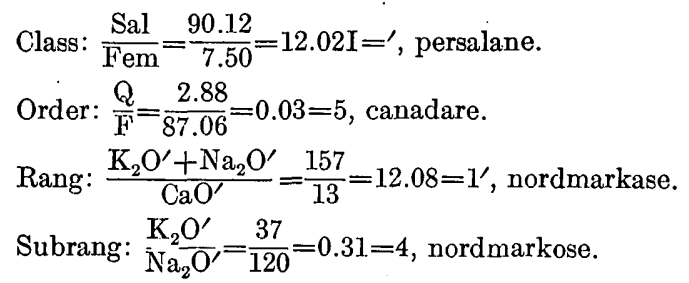

Its intermediate position in regard to class and rang shows a near relationship to umptekose in Class II and to laurvikose in rang pulaskase of Class I.

East Maui.

The great volcano of Haleakala, East Maui, has long been celebrated, especially for its wonderful summit crater, but the only important earlier petrographic description of its lavas is embraced in the publication by E. S. Dana ${ }^{1}$ already cited. The specimens described by him were collected by J. D. Dana (?) and nearly all came from the central crater or near it. As my own collection contains all the earlier recognized types and is probably from the same or adjacent localities, the description may profitably consider all the material together.

To begin with, it seems probable that only comparatively recent lavas of this center are represented in the collections made. The deeper canyons not occupied by recent flows may exhibit much older lavas than any to be mentioned, and of different types. The basis for this view is presented in another place (p. 92).

The crater of Haleakala, the west rim of which has an altitude of 9,000 to 10,000 feet, is approached by trails only from the south, through the Kaupo Gap, or from the north, by a long, gentle ascent to the western rim and a descent into the crater at its southwestern extremity. My route led through the Kaupo Gap, along the full east-west length of the crater and down by the trail on the northern slope. The rocks collected by me represent the flow descending from the Kaupo Gap to the sea, several recent eruptions within the crater, and the rim rock on the west. None came from the walls of the crater. There are but two general varieties among these rocks.

PICRITIC BASALT.

Occurrence.-A black vesicular basalt whose abundant and prominent phenocrysts of augite and olivine led the elder Dana to characterize it as "augitophyric and chrysophyric" covers much of the surface sloping away from the western rim of the crater, but I do not know how far it extends down the slope. Several observers have spoken of the well-formed augite crystals which have weathered out of this rock and strew the ground in some places along the trail.

Much vesicular basalt closely resembling the rock just described is also found on the floor of the crater, according to J. D. Dana. I saw some such lava and collected a specimen of it from the north base of the cone called Namaunakeakua, beside the trail about 2 miles from the western extremity of the crater.

Description.- The dark rock is of prominent porphyritic fabric, its well-formed, fresh augite and olivine phenocrysts, many of which exceed 0.5 millimeter in diameter, lying in a sharply defined groundmass of approximately equal amount-that is, the rock is sempatic. The augite often exhibits a pale violet outer zone and is full of ferritic devitrified inclusions. The olivines

1 Am. Jour. Sci., 3d ser., vol. 37, pp 441-467, 1889. 
are unusually fresh, seldom being even stained through alteration. There are many roundish smooth-walled pores or vesicles.

The groundmass is fine grained, nearly holocrystalline, and consists of an obscure mixture of augite and magnetite with inconspicuous labradorite microlites and a few minute grains of nephelite. The feldspar is considerably less than the amount indicated by the norm calculated from the analysis; so that presumably the augite is rather highly aluminous.

Chemical composition.-This basalt from Haleakala has been analyzed by George Steiger with the result given below. The norm is also stated with the analysis.

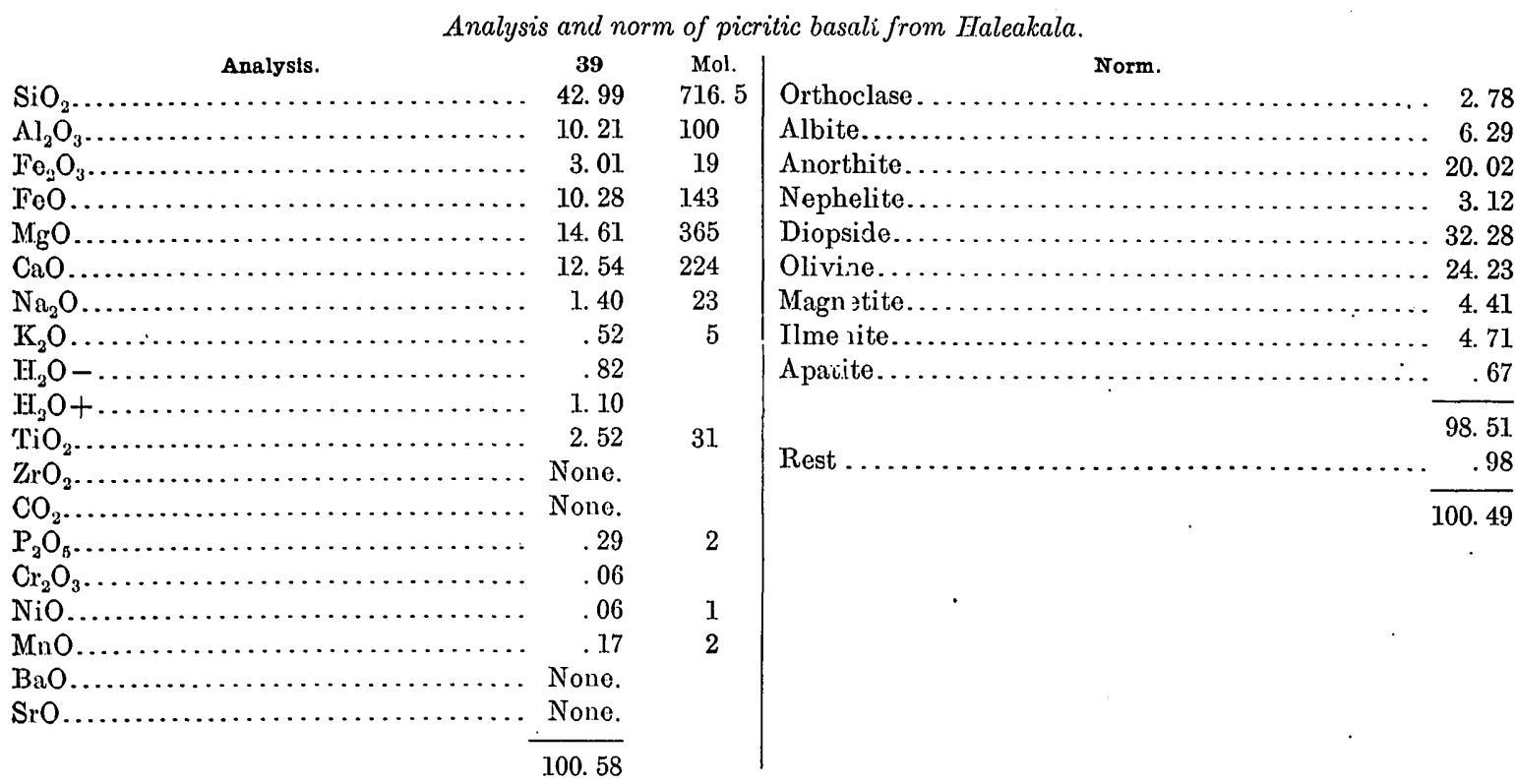

Qualitative classification.-This basalt is to be compared with the "ultrafemic basalt" of Mauna Loa, the porphyritic gabbro of Kilauea, and the chrysophyre of Puna, on Hawaii, to be described later, but the Haleakala rock is relatively so much richer in lime that it approaches the melilite-bearing rocks in composition. The silica, however, is so high that akermanite does not appear in the norm.

In Division XIII of the table on page 76 it is shown that one of the analyzed gabbros of Rosswein, in Saxony, a trachydolerite of the Rhöngebirge, and an essexitic gabbro of Tahiti are near analogues of this basalt. Rocks closely corresponding to the basalt from Haleakala in composition seem to be rare. With the related lavas of Hawaii it may be appropriately called picritic basalt to indicate its intermediate position between plagioclase basalts and peridotitic basalts, especially in magnesian minerals.

Quantitative classification.-The following data show the relations of this rock in the quantitative system:

$$
\begin{aligned}
& \text { Class: } \frac{\mathrm{Sal}}{\mathrm{Fem}}=\frac{32.21}{66.30}=0.486=\mathrm{IV} \text {, dofemane. } \\
& \text { Order: } \frac{\mathrm{P}+\mathrm{O}}{\mathrm{M}}=\frac{56.51}{9.12}=6.2=(1) 2 \text {, scotare. } \\
& \text { Section: } \frac{\mathrm{P}}{\mathrm{O}}=\frac{32.28}{24.23}=1.33=3 \text {, texiare. } \\
& \text { Rang: } \frac{(\mathrm{Mg} \cdot \mathrm{Fe}) \mathrm{O}}{\mathrm{CaO}}=\frac{511}{152}=3.36=2 \text {, uvaldase. } \\
& \text { Subrang: } \frac{\mathrm{MgO}}{\mathrm{FeO}}=\frac{365}{146}=2.5=2 \text {, uvaldose. }
\end{aligned}
$$

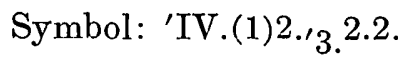

As to order, the rock is transitional between scotare and hungarare. In the latter, perpolic order, rossweinose corresponds to uvaldose, and rossweinose-uvaldose expresses the classification more accurately than a single term. 
General character and occurrence.-The other rocks from Haleakala described by Dana, as well as those collected by me, appear to form a group of contemporaneous lavas of closely allied types, the general nature of which may be indicated by the term essexitic andesite or trachyandesite. They are predominantly soda-rich plagioclastic lavas with some orthoclase and nephelite and earry olivine with other mafic silicates. They might have been termed trachydolerite by Rosenbusch.

The most felsic rock of this group occurs as the principal type of the coarse breccia of White Hill (elevation, 9,870 feet), situated in the extreme southwestern angle of the crater of Haleakala. It is a dull-gray, finely banded aphyric aphanite. The banding is in general plane-parallel but wavy in detail and is clearly fluidal. Fracture surfaces nearly parallel to the banding exhibit a slight satiny sheen. The rock is nearly massive, but a fow minute pores can be seen with a lens.

This rock apparently forms much of the débris of the western part of the crater, produced by explosive eruptions from several centers marked by tuff cones of gray color. It seems almost certain that J. D. Dana ${ }^{1}$ refers to White Hill in speaking of "a cone near the place of descent" from the western rim, which is made up of "gray, compact, scarcely vesiculated rock." Probably also the "dark bluish-gray rock of uniform texture" described by E. S. Dana ${ }^{2}$ (No. 29) came from White Hill or some adjacent cone. E. S. Dana noted the forked olivines and flakes of biotite.

J. D. Dana ${ }^{3}$ states that "the lava of the walls [of Haleakala] is in part scoriaceous; but on the south and southwest sides it was commonly a very compact, rather light gray variety of basalt, like that of the projected blocks about some of the cones." He further states that "Pendulum Peak, near the summit, just north of the southwest corner of the crater * * * consists largely of this compact light-gray basalt, with rarely any vesiculation visible without the aid of a pocket lens." But it is plainly unwarranted to assume too positively the identity of other massive rocks with that of White Hill, in the absence of microscopical examination.

A dark-gray aphanitic rock of few small phenocrysts, poor in olivine; occurring at the summit ("von der Spitze") of Haleakala, is the only specimen from East Maui in the Schauinsland collection, described briefly by Möhle. ${ }^{4}$

The northern inner slopes of the great crater are dotted by many tuff cones, and here and there dikes or small plugs are notable. At one of these cones northwest of Oili Puu, in which the so-called "Crystal Cave" is situated, the breccia is largely made up of gray.aphyric aphanite similar to the rock of White Hill.

North of Oili Puu, near a small spring of much importance to travelers desiring to camp in the crater, is a dike of banded aphyric aphanite. This rock is also much like that of White Hill but seems slightly more basic. It contains microphenocrysts of olivine and magnetite, the largest seen being about 0.5 millimeter in diameter, while the grains of augite, olivine, and magnetite in the holocrystalline groundmass average about 0.02 to 0.03 millimeter.

The lavas that form the floor of the eastern part of the crater and extend out through the Kaupo Gap to the sea are darker than the varieties described but have nearly the same character. They are believed to be fairly represented by two specimens obtained from a ravine west of Vieira's ranch house, situated at about 1,000 feet above the sea near the point called Pukalale, on the trail to the Kaupo Gap.

Rocks analyzed.-The gray aphyric rock of White Hill and the darker, more basaltic type of Vieira's ranch seem to represent about the extremes of these rather alkalic rocks of Haleakala, and they vere accordingly chosen for chemical analysis. These two rocks will be described in some detail.

The rock of White Hill (No. 4) is almost as completely aphyric in its microscopical as in its megascopical texture, prominent crystals belonging to an early generation of apatite and magnetite being the largest components. The microphenocrysts of magnetite measure about.

1 Characteristics of volcanoes, p. 275, New York, 1890.

2 Am. Jour. Sci., 3d ser., vol. 37, p. 463, 1889.
3 Op. cit., p. 276.

4 Neues Jahrb., Beilage Band 15, p. 68, 1902. 
0.3 millimeter in diameter. The rock is holocrystalline and consists of dominant felsic minerals, with augite, magnetite, olivine, and apatite, named in the order of abundance. Of the felsic minerals the chief is oligoclase-andesine in lath-shaped microlites and tablets making nearly half the rock. Orthoclase is determinable in irregular tablets or interstitial particles but not in the amount contained in the norm (given below). Nephelite, too, is found in minute grains, much less in amount than is shown by the norm. Augite and olivine occur in minute prismoid, the augite having rounded ends and the olivine irregular or forked termination. This habit of olivine is very different from that observed in the basalts. A few flakes of brown biotite were noted. Apatite occurs in phenocrysts rendered dark by inclusions, and more abundantly in colorless needles. Magnetite is developed principally as a fine dust, of the second generation. 'There is almost no trace of alteration of the minerals named, even the olivine being for the most part unstained.

The rock exposed in a ravine west of Vieira's ranch house (No. 6) is vesicular in places, but much of it is dark and aphanitic, either aphyric or aphanophyric by virtue of small andesine phenocrysts with which olivine is in some places associated. The megascopically aphyric rock is microcrystalline and microporphyritic through phenocrysts of andesine (1 millimeter) and magnetite ( 0.6 millimeter). Augite and olivine are somewhat more abundant than in the type first described. Fluidal texture is expressed by the arrangement of oligoclase-andesine and augite microlites. A study of the groundmass with a high power reveals two colorless minerals, mainly in anhedral grains, forming the matrix for the better-formed microlites. One of these, of very faint birefringence, has about the same index as Canada balsam and occurs rarely in rectangular forms. This is regarded as nephelite. The other mineral has stronger birefringence but a distinctly lower index than balsam and is considered to be orthoclase or some alkali feldspar. A few irregular particles of clear glass have.been noted. Orthoclase and nephelite evidently make up a far greater proportion of this rock than superficial examination would suggest, but not so large a part as the norm calculated from chemical analyses indicates. The black rock of the Kaupo Gap has the habit of the many aphanitic basalts of Kilauea and other centers, but the analysis to be given shows that the microscopical resemblance to the rock of White Hill, which is emphasized by intermediate types, is a true expression of its character. It is an olivine-bearing augite andesite, related to the essexitic lavas, though not so closely as the rock of White Hill.

Chemical composition.- The chemical character brought out by the accompanying analyses and norms shows the rocks to be far different from basalts.

Analyses and norms of essexitic andesites from Haleakala.

\begin{tabular}{l|rr|r|r|r|r|r}
\hline \multicolumn{2}{c|}{ Analyses. } \\
\hline
\end{tabular}


4. White Hill (9,870 feet) in southwest angle, crater of Haleakala. Contains also $\mathrm{ZrO}_{2} 0.01, \mathrm{FeS}_{2} 0.03, \mathrm{~V}_{2} \mathrm{O}_{3} 0.15$, no $\mathrm{Li}_{2} \mathrm{O}, \mathrm{NiO}$, or $\mathrm{Cr}_{2} \mathrm{O}_{3}$. Analyst, W. F. Hillebrand.

6. Ravine west of Vieira ranch, south of Kaupo Gap, Haleakala. Analyst, George Steiger.

Quantitative classification.-The classification of rock No. 4 by the quantitative system is indicated by the following ratios:

$$
\begin{aligned}
& \text { Class: } \frac{\mathrm{Sal}}{\mathrm{Fem}}=\frac{72.02}{27.59}-2.6 \mathrm{I}=\mathrm{II} \text {, dosalane. } \\
& \text { Order: } \frac{\mathrm{L}}{\mathrm{F}}=\frac{9.09}{62.93}=0.144=(5) 6 \text {, norgare. } \\
& \text { Rang: } \frac{\mathrm{K}_{2} \mathrm{O}^{\prime}+\mathrm{Na}_{2} \mathrm{O}^{\prime}}{\mathrm{CaO}^{\prime}}=\frac{24+98}{53}=2.3=2 \text {, essexase. } \\
& \text { Subrang: } \frac{\mathrm{K}_{2} \mathrm{O}^{\prime}}{\mathrm{Na}_{2} \mathrm{O}^{\prime}}=\frac{24}{98}=0.24=4, \text { essexose. }
\end{aligned}
$$

The amount of nephelite is barely sufficient to place the rock in the lendofelic order and its true position is expressed by the compound term akerose-essexose, akerose being the corresponding subrang of the perfelic order germanare.

The ratios for rock No. 6 are as follows:

$$
\begin{aligned}
& \text { Class: } \frac{\mathrm{Sal}}{\mathrm{Fem}}=\frac{70.08}{29.15}=2.4=\mathrm{II} \text {, dosalane. } \\
& \text { Order: } \frac{\mathrm{L}}{\mathrm{F}}=\frac{6.25}{63.83}=0.098=5^{\prime} \text {, germanare. } \\
& \text { Rang: } \frac{\mathrm{K}_{2} \mathrm{O}^{\prime}+\mathrm{Na}_{2} \mathrm{O}^{\prime}}{\mathrm{CaO}^{\prime}}=\frac{118}{46}=2.56=2, \text { monzonase. } \\
& \text { Subrang: } \frac{\mathrm{K}_{2} \mathrm{O}^{\prime}}{\mathrm{Na}_{2} \mathrm{O}^{\prime}}=\frac{23}{95}=0.24=4 \text {, akerose. }
\end{aligned}
$$

Symbol: II. $5^{\prime} \cdot 2.4$.

Here the nephelite is less than in No. 4 and the rock falls in the perfelic order but is intermediate toward norgare.

\section{ISLAND OF HAWAII.}

CENTERS OF ERUPTION.

The island of Hawaii, the largest and most recent of the group, has, because of its active volcanoes, Mauna Loa and Kilauea, received much more attention than the others. Besides the two volcanoes mentioned there are three others that have taken part in building up the island. The oldest of these is represented by the Kohala Mountains, forming the northern peninsula of the island, a district about 21 miles long from northwest to southeast and 13 miles wide. Its highest point has an elevation of 5,489 feet above the sea. Little has been published concerning the lavas of this region beyond the fact that they appear to belong to the basalt family, with a tendency toward the andesites.

The central-western zone of the island contains Mount Hualalai, a volcanic cone rising to an elevation of 8,273 feet with a basal diameter of nearly 20 miles, but dwarfed by comparison with its gigantic neighbors, Mauna Kea and Mauna Loa, the lavas of which surround it on three sides.

The various lavas of the island will be considered in groups corresponding to the several centers of eruption.

\section{KOHALA MOUNTAINS.}

Among the specimens from Hawaii described by $\mathrm{E}$. Cohen ${ }^{1}$ in 1880 , were several from the Kohala Mountains, no detail of locality being given. The rocks mentioned by Cohen as occurring in the Kohala district embrace normal plagioclase basalts rich in olivine and others which he characterizes as forming a transition to the augite andesites. He does not state how many specimens from Kohala he examined.

1 Neues Jahrb., 1880, vol. 2, pp. 23-62. 
Of the normal basalts one Kohala rock is specified ${ }^{1}$ as containing olivine in its groundmass in addition to its occurrence as phenocrysts. The transitional rocks are described as compact or vesicular, gray in color, and connected with basalt by the constant presence of scanty olivine, and with augite andesite by the abundant basis and above all by the scarcity of augite, which is in some rocks not clearly present. Plagioclase is much more abundant than augite in all the rocks. ${ }^{2}$ That such rocks are not normal basalts may, be granted, but the argument that the scarcity of augite shows relation to augite andesite is hardly convincing.

Dana and Hitchcock in their works on Hawaiian volcanoes mention the Kohala region only with reference to its relative age and topography. Dutton makes a general statement concerning the rocks which, although based on megascopic examination alone, seems worthy of citation, for it indicates a general character for these lavas quite different from that of the other centers. Dutton remarks of the Kohala volcano: ${ }^{3}$

Like all the other volcanoes of these islands its lavas belong to the basaltic group. Still they have peculiarities which serve to distinguish them from those of Mauna Kea and Mauna Loa. They appear less ferruginous and much more feldspathic. Olivine does not form, as a rule, so important a part of the mineral contents of the lavas, though in some of them it is fairly abundant. The group taken as a whole shows a tendency to approach the andesites. Extreme cases may be found in which it is difficult, apart from the general relations, to say whether they should be classed among the augitic andesites or among the normal basalts. Those intensely black, dense, and highly ferruginous lavas which are universal on Mauna Loa and Kilauea do not occur on the Kohala Mountain, so far as I have discovered. ${ }^{4}$

There is no statement in Dutton's report as to the extent of his observations in the Kohala Mountains, but one may infer from the text that he saw only the southern portion.

The remark by Dutton that the lavas of Kohala Mountains are more feldspathic than normal basalts and approach the andesites is confirmed by Lyons in a substantial way through his chemical analyses of two lavas. One of these (No. 3 of the rocks analyzed) Lyons ${ }^{4}$ describes as follows: "It is a bluish-gray, compact, minutely crystalline lava, containing much feldspar and very little chrysolite, and is the prevailing rock in the Kohala Mountain, at least in the Waimea neighborhood." This type is in fact far from normal basalt in composition, as shown by the analysis quoted in the chemical discussion. The rock is a dosalane and falls in the subrang akerose of the quantitative system. Its norm contains 3.6 per cent of quartz and 82 per cent of feldspar. With the exception of the soda trachytes, it is the most salic known lava of the Hawaiian group.

The other rock analyzed by Lyons 5 " is also a lava from the Kohala Mountain, $* *^{*} *$ a somewhat vesicular stony lava of rather light color, porphyritic with white crystals of feldspar."

The norm of the analysis of this second lava also shows some quartz, which means that the mode or actual rock can have little or no olivine. Probably it should be called augite andesite. The chemical relations of both rocks will be pointed out in the second part of this paper.

My observations on the rocks of the. Kohala Peninsula are limited to what could be seen during a two hours' stop of the steamer at Mahukona, on the west coast. The gentle slopes extending from the sea for several miles back to the main axis of the Kohala Mountains appear to be made up of long, narrow lava flows from sources far up in the range. This leeward slope of the mountains is not much dissected by erosion.

The lava near Mahukona is probably well represented by specimens I obtained in a railway cut near and north of the boat landing. They are from the more massive parts of thin flows, vesicular or scoriaceous in their upper and lower zones. The rock is black, aphanitic, and almost aphyric, only a few tabular labradorite phenocrysts being visible megascopically. Under the microscope it is holocrystalline or nearly so and consists of feldspar, augite, olivine, magnetite, and apatite, named in order of abundance.

The feldspar is labradorite in the phenocrysts and andesine in the abundant microlites of the groundmass, with probably a very scanty amount of orthoclase in irregular particles.

\footnotetext{
1 Neues Jahrb., 1880, vol. 2, p. 47.

$2 \mathrm{Idem}$, pp. $51,52$.

B U. S. Geol. Survey Fourth Ann. Rept., p. 171, 1884

4 It should be noted that Dutton's failure to contribute to the microscopical petrography of Hawaii is due to the loss of his specimens while on the way to Washington.

- Am. Jour. Sci., 4 th ser., vol. 2, p. 425, 1890 .

$48730^{\circ}-15-3$
} 
The andesine microlites of fluidal arrangement are separated by augite and olivine grains or prismoids with a tendency to ophitic fabric in some places and with thin wedges of ferritic glass in others.

Olivine is scarcely more prominent than in the trachydolerites of Haleakala, with which this rock exhibits close relationship. No nepheline could be detected under the microscope.

It seems not unlikely that this rock is allied to that from "Kohala Mountain" analyzed by Lyons. It may have more olivine, but it is certainly not a normal olivine-plagioclase basalt like many of the lavas of Hualalai, Mauna Loa, and Kilauea.

\section{MOUNT HUALALAI.}

Mount Hualalai is in many respects a typical basaltic volcano of the Mauna Kea type. It has very gentle slopes and its summit is characterized by a group of tuff cones and pit craters. There is no central or dominant crater of the caldera type. The last eruption of the volcano, which took place from a vent on the northwestern slope, in the early part of the last century, produced lava flows extending to the sea. It is said that more than 150 cones and pit craters may be counted on the slopes of this volcano, making its present condition much like that of Mauna Kea:

References in literature to the character of the lavas of Hualalai are scanty. Among the rocks described by Cohen ${ }^{1}$ in 1880 are some from Hualalai which he calls normal plagioclase basalt with much olivine, while others belong to the transitional group mentioned in discussing the rocks of Kohala.

Dutton speaks of the Hualalai lavas as rich in olivine and highly ferruginous and says that they closely resemble those of Mauna Loa. Daly ${ }^{2}$ incidentally refers to the lavas of Hualalai as mainly olivine basalt.

My observations of Hualalai were made from a cattle ranch near Puu Waawaa, on the northeastern slope, as a base. I made one trip to the summit and examined the rocks exposed on the Government road crossing the northern slope.

Basaltic lavas. - The various flows exposed on the Government road from Kailua to Waimea, as it traverses the northern slope of Hualalai at an elevation of 1,800 to 2,200 feet, are of typical basaltic appearance. They are black and more or less vesicular, and their surfaces in many places exhibit the superficial characteristics of the aa or pahoehoe flows. Where massive or finely vesicular they are olivine aphanophyres, the groundmass often being greatly in excess of the phenocrysts-that is, they are perpatic. Labradorite is commonly formed in a few phenocrysts, and augite more rarely.

The groundmasses of the rocks examined are holocrystalline and consist of plagioclase, augite, olivine, and magnetite. The feldspar is labradorite as a rule and it varies in abundance, being in some rocks much subordinate to augite and olivine. Magnetite is not notably abundant.

All other observed surface lavas of the mountain are probably olivine-plagioclase basalts, but specimens were not generally taken and microscopical examination is of course necessary for positive determination. A flow exposed in the walls of a pit crater on the north slope near the summit is a perpatic aphanophyre containing less plagioclase than is found in the flows exposed on the road below.

Dunite, gabbro, and other granular inclusions in basalt.- Some of the flows crossed by the road on the north slope of Hualalai contain numerous inclusions of granular rocks, which are of several kinds. These xenoliths are generally not much more than 1 inch in diameter, but a few considerably larger ones were seen. They are subangular or rounded, fresh, and of mediunc to fine grain. Their chief constituents can be recognized megascopically. It is plain that olivine, plagioclase, and pyroxene are present in very variable proportions. No fragments of lava or of rocks of exogenous origin were observed in association with these xenoliths.

The origin of the olivine-bearing rocks commonly found in basalts has been variously interpreted, but there seems to be no reason to doubt the genetic relation of these xenoliths to 
the basalt. They are no doubt deep-seated differentiation products of the basaltic magmas formed under unknown conditions, and are common at centers of such basic rocks. Their occurrence in the basalt of Hanapepe Canyon, Kauai, has been noted above. "Olivine bombs" have been observed by Dana, Lyons, and Möhle on Oahu, and by Daly, Hitchcock, and Dutton in tuff eruptions of Mauna Kea.

The fragments in the basalt of Hualalai are particularly abundant about $1 \frac{1}{2}$ miles east of McGuire's ranch on the road, but similar occurrences were noted nearer to Puu Waawaa. The varieties collected may be called dunite, wehrlite, and olivine gabbro, though the last includes transitional phases to a gabbro with some enstatite and very little olivine.

Some of the dunite fragments are fresh, pure, typical olive-green rocks with but traces of augite. Small amounts of piccotite and magnetite are included in the olivine, but magnetite and other iron oxide grains are otherwise lacking.

The wehrlite has more diallage than labradorite, and olivine is subordinate. Magnetite is lacking and so is apatite. The diallage parting is very pronounced in some augite grains.

The gabbroic rocks have labradorite or bytownite as their most abundant constituent, with augite (some of it diallagic) and olivine in variable amount. Magnetite grains are plentiful in one piece. No orthoclase, highly sodic plagioclase, hornblende, or biotite has been noted.

Basaltic xenoliths.-On the summit of Hualalai there was found a block of common basalt containing a fragment of basalt of unusual texture and some peculiarities of composition. It is a pinkish-gray fine-grained porphyry with many white specks of highly calcic plagioclase, determined as bytownite in several crystals. These spots are not single crystals, however, but represent aggregates of several grains irregularly intergrown. The groundmass is holocrystalline and consists of plagioclase, augite, olivine, brown hornblende, biotite, magnetite, and apatite. Both the hornblende and the biotite are sparingly developed and in some grains the former is intergrown with augite. The plagioclase microlites vary in composition from the highly calcic central laminæe to the strongly sodic angular projections between other mineral grains. Daly ${ }^{1}$ refers to "projected blocks" found on the summit of Hualalai and describes one of them as an "ultrafemic gabbro" and two others as "holocrystalline equivalents of the normal olivine basalt of the island."

Trachyte of Puu Waawaa and Anahulu.-On the north-northeastern slope of Hualalai is a notable cone called Puu Waawaa, the name signifying fluted or ribbed hill, according to Hitchcock. Its base is about 3,000 feet above the sea, and it rises with very regular form for several hundred feet. This cone is much more deeply scored by radial ravines than any other one of Mount Hualalai seen by me, and the name seems to give emphasis to this feature as being unusual.

The cone of Puu Warwar is made up of well-stratified tuffs, so far as erosion has revealed its constitution, and it may be plausibly regarded as of this character throughout. The materials appear to be all trachytic ash, pumice, and obsidian, of dark-gray color. No basalt was found in the tuft, although many fragments are dark and aphanitic and seem basaltic at first sight.

North of Puu Waawa and separated from it by a shallow valley through which basalt streams from Hualalai and Mauna Loa have flowed is a terrace, the upper end of which is at a small cone called Puu Huluhulu. This terrace has a gently sloping surface and extends northward to an elevation of about 1,200 feet above sea level, where it abruptly ends near a point called Puu Anahulu, presenting a cliff face to the north, as it does also along its western border. On the east it merges with the lower slopes of Mauna Loa, and several lava streams, notably that of 1859 , have in fact flowed out upon this terrace and tongues of lava have even passed over the western cliff.

This terrace belongs to an old topography, as may be seen even from the deck of a steamer passing along the western coast or from the road skirting the shore. Dutton noted ${ }^{2}$ it from the road and supposed it to be proof of uplift. Where the Government road ascends the 
steep face of this terrace, in pits for road metal, and at many exposures along the face, it can be seen that the terrace is made up of a coarse agglomerate-like mass of trachyte bowlders or blocks, many of which are greatly decomposed, producing a light-colored clay.

The materials of Puu Waawaa and the Anahulu terrace have been described by me in detail $^{1}$ and shown to be trachyte rich in soda and containing only about 10 per cent of mafic minerals. Chemical analysis was made of the obsidian from Puu Waawaa and of the freshest rock of the terrace. Without going into petrographic details here it may be pointed out that the pitchstone has nearly the composition of several rocks of Norway, as will be clear from the analyses of analogous rocks given on page 64 .

Puu Waawa is topographically on the slope of Mount Hualalai, whose basaltic lavas surround it and bank up against it on the upper side. The relations are such as to make it probable that the unique trachytic eruption of this cone must have occurred during the epoch of Hualalai itself. The cone is more denuded than the recent cones of basaltic character scattered over the volcano, yet it has not been sufficiently eroded to permit the conception that it entirely antedates the greater mountain.

The occurrence of these trachytic rocks is plainly one of great interest in the history of the island, but present knowledge does not suffice for extended discussion.

MAUNA KEA.

It is rather remarkable that so little definite information has been published regarding the lavas of Mauna Kea, next to Mauna Loa the largest volcano of the Hawaiian Islands. Cohen, Merrill, and Daly appear to be the only petrographers who have had opportunity to study rocks from this source.

Rocks described by Cohen.-In 1876 and 1880 E. Cohen ${ }^{2}$ described a considerable number of lava specimens from Hawaii collected for him by Dr. William Hillebrand. The greater part of this collection represented basaltic glasses from Kilauea and Mauna Loa, which had for Cohen special interest and which he described with corresponding fullness. But he also referred to massive, nearly crystalline rocks, though the group descriptions are brief and details as to locality are scanty, owing to the meagerness of the original labels. Some of these specimens came from Mauna Kea and others from Hualalai or Kohala, as has been mentioned.

The Mauna Kea rocks studied by Cohen are referred by him to normal plagioclase basalt, typical augite andesite, and a group of transitional varieties. The two normal basalts of Mauna Kea are said to differ from others of the island in that they are dense light-gray rocks with platy parting and that olivine is restricted to the groundmass. ${ }^{3}$ The transitional varieties are described with those of Hualalai and Kohala.

Two rocks of Mauna Kea called augite andesite are described in some detail by Cohen, with the remark that in the opinion of Dr. Hillebrand they are much older than the other specimens from that mountain and probably represent the core of the volcano. The ground for this opinion is not given, but Cohen points out that the unusual character of the rocks is in itself confirmatory of Dr. Hillebrand's idea. One of these andesites is said to occur at about 450 meters below the summit. It is a bluish-black dense rock ringing like phonolite when struck. It has only a few microphenocrysts of plagioclase lying in a groundmass of plagioclase, augite, and magnetite, and a film of glass base. The second rock is greenish gray and has a groundmass like the first but contains pores filled with radiate masses of undetermined zeolites, which Cohen believes to be primary. No detail of locality is given for this variety.

Lavas collected by Preston.-In connection with studies of the density of Mauna Kea, E. D. Preston collected a number of specimens representing certain lavas of the volcano. These are briefly described by G. P. Merrill in Preston's report. ${ }^{4}$ Through the courtesy of Dr. Merrill I have had opportunity to examine Preston's collection and the thin sections, now belonging to the United States National Museum.

1 Jour. Geology, vol. 12, pp. 510-523, 1904

2 Neues Jahrb., 1880, vol. 2, pp. 23-62.
3 Idem, p. 49.

1 U. S. Coast and Geodetic Survey Ann Rept., 1893, pt. 2, appendix 12, pp. 630-632. 
The specimens were collected at intervals along the trail from Waimea, on the north of Mauna Kea, along the western slope of the mountain to Kalaieha in the saddle on the south, between Kea and Loa, on the trail thence to the summit, and at several places near the Waiau station occupied by Preston in his observations. Unfortunately the character of many specimens precludes satisfactory microscopical determination. Most of them are hypocrystalline, the dominant glassy or ferritic base permitting only general statements of composition. It is not unnatural to suppose that most of the specimens may come from cinder cones or local lava streams and thus represent only comparatively recent products and not the larger flows of the volcano.

All these rocks are no doubt olivine-plagioclase basalt. Their characteristic feature, compared with other basalts described thus far in this volume, is the dominance of plagioclase and augite over olivine among the phenocrysts. The plagioclase is highly calcic, and one may suspect that iron oxides are more than usually abundant in the groundmass.

Observations by Dutton.-C. E. Dutton's references to the general character of lavas of Mauna Kea apparently confirm the suggestion made above that olivine is not abundant in them. He remarks: ${ }^{1}$

They [the lavas of Mauna Kea] have no great variety, but at the first glance they show a well-marked difference as compared with those from Mauna Loa. Olivine is abundant but is never seen in such excessive quantities. On the other hand, the feldspars are present in great quantity in well-marked tabular crystals, and many large crystals of augite occur. The groundmass in the majority of cases inclines to bluish gray instead of being greenish black, as in most of the lavas of Kilauea and Mauna Loa.

Near the summit cone of the mountain there occurs a dense light-gray rock long used by native Hawaiians for adzes, poi pounders, and other implements. Dutton ${ }^{2}$ refers to it-

as undoubtedly a basalt possessing an abundance of triclinic feldspar in exceedingly minute crystals and without olivine. It appears to be identical with a very large proportion of the basalts occurring in the western portion of the United States.

The correctness of the last remark may be questioned.

Rocks noted by Hitchcock.-The rock used for implements is also mentioned by C. H. Hitchcock, ${ }^{3}$ but he gives no further clue to its character. At the summit cone of Mauna Kea there are, according to Hitchcock, many bomblike masses, with a core of olivine (dunite?) and an envelope of "white basaltic rock" which has a superficial resemblance to granite. It is suggested by him that this outer zone of the bombs is allied to the dense rock used for implements. Both occurrences call for investigation by a petrographer.

Rocks described by Daly.-In 1909. R. A. Daly ascended Mauna Kea, apparently by the usual route from the south, and reports ${ }^{4}$ that from the 6,000 -foot contour to about the 12,000 foot contour "The lava flows seem to be very uniformly composed of a rock species which is intermediate between typical olivine basalt and a true augite andesite." A dark-gray vesicular lava from the 11,000-foot contour, which is thought to be representative of that part of the volcano, was analyzed for Daly in the chemical laboratory of the United States Geological Survey. This analysis is quoted in the table on page 47 as No. 7 . This rock has only a few very small olivine and augite phenocrysts but many more of labradorite $\left(A b_{1} A n_{1}\right)$. The pilotaxitic groundmass is nearly free from olivine. As shown in the table of norms (p. 51), the analysis yields a little normative quartz, and by the quantitative classification the rock is an andose with more than 68 per cent of salic molecules.

The upper 2,000 feet of Mauna Kea consists chiefly, according to Daly, ${ }^{5}$ of a rock called trachydolerite, though its analysis is very similar to that of the andesitic basalt. This dense gray rock his a few minute phenocrysts of olivine and augite and many of andesine-labradorite with more alkalic borders. Orthoclase may occur as interstitial material. Daly also gives an analysis of this rock (No. 5 of the table on p. 47). It is an andose with a little normative olivine. The analogues of these two rocks are given in Division IV of the table on page 67.

1 U. S. Geol. Survey Fourth Ann. Rept., p. 160, 1884.

Idem, p. 104

3 Hawaii and its volcanoes, 2 d ed., p. 52, 1911.
4 Jour. Geology, vol. 19, p. $297,1911$.

- Idem, p. 299. 
From Daly's observations it appears that on the surface of Mauna Kea there are lavas approaching those known in Kohala. It is not yet shown that in either mountain such lavas constitute the main mass. Daly's view that Mauna Kea consists mainly of these nonbasaltic lavas, above the level of 6,000 feet, and that such distribution speaks for gravitative differentiation is discussed in a later section of this paper (p. 89).

In both trachydolerite and andesitic basalt Daly found many lherzolitic nodules, analogous to those in the olivine basalt of Hualalai and of other localities in Oahu and Kauai that have been mentioned. These nodules are probably the same as those referred to by Hitchcock, noted above.

Other rocks on Mauna Kea.-The deep canyons near the coast on the east side of Mauna Kea give an opportunity for getting at lavas somewhat below the general surface, which has not yet been improved by any geologist. The andesites described by Cohen indicate the presence of other than nearly normal basaltic rocks in this volcano, but their significance is unknown. Dr. Hillebrand's theory that they represent the core of the mountain has no known foundation. In this connection, it is interesting to note that from his observations Preston ${ }^{1}$ calculates the mass of Mauna Kea to have a mean density of 3.26 , which is greater than that of either andesite or of the basalts collected by him.

\section{MAUNA' LOA.}

Much has been written concerning Mauna Loa, the greatest of Hawaiian volcanoes still active. The phenomena of its historic eruptions are described at length by Dana, Dutton, Brigham, Hitchcock, and many other observers, but comparatively little exact information is available concerning the petrography of its lavas, except the most recent flows. This is natural, for the flows of the last century are bare, while older ones are as a rule covered by dense forests below timber line, and the difficulties besetting a study of the upper zone deter most visitors from attempting it.

No deep canyons have yet been cut into the mass of this new mountain, and probably the oldest lavas visible are those exposed in the walls of Mokuaweoweo, the summit caldera. Fortunately some attention has been given to these flows. Existing data concerning the rocks will be presented in chronologic order.

Rocks described by Cohen.-Many specimens of the Hillebrand collection, described by Cohen, appear to have belonged to Mauna Loa, but these were largely glassy rocks of recent eruptions and with a few exceptions the determinations are very general.

Olivine-rich plagioclase basalt is reported by Cohen ${ }^{2}$ from the crater of Mokuaweoweo. A basaltic pumice belonging to the flow of 1868 was chemically analyzed by Cohen ${ }^{3}$ and it too clearly belongs in this class. The analysis is quoted as No. 32 of the table of analyses (p. 48).

Rocks described by E.S. Dana.-About 70 specimens of Mauna Loa lavas, mainly from the crater Mokuaweoweo, were collected for J. D. Dana by Rev. E. B. Baker, of Hilo, and the description of these rocks by E. S. Dana ${ }^{4}$ gives much valuable information. Twenty specimens came from talus from the wall between the southern and central portions of the crater, 12 from the east side of the central pit, and others from various places in and about the caldera. The most marked differences in composition noted among these rocks lie in the variable amount of olivine. Some are rich in this mineral and others contain little or none.

One of the two principal groups is described as very fine grained and nearly or quite holocrystalline, of clinkstone-like appearance. It consists mainly of plagioclase augite and magnetite. "Chrysolite *** is absent or only sparingly present.". This rock is, however, called basalt.

The other notable group is prominently chrysophyric, the olivine in some places forming one-half of the mass. These are rather basic olivine-plagioclase basalts of various textures.

A less common type of rock from Mokuaweoweo is described as "light gray in color, not vesicular, and sparingly provided with chrysolite if it is present at all, and characterized by a

${ }_{1}$ U. S. Coast and Geodetic Survey Ann. Rept., 1893, pt. 2, appendix 12, p. $630 . \quad{ }^{3}$ Idem, pp. $34,41$.

2 Neues Jahrb., 1880, vol. 2, p. 49. 
very uniform granular mixture of augite and plagioclase. A specimen taken from a vein of the western wall [of the crater] belongs here." Other localities for this type are specified. The collection included also some glassy or hypocrystalline forms, the exact composition of which is not determinable.

It is plain that the rocks of Mokuaweoweo studied by Dana must have a considerable range in chemical composition, and it seems probable that some of them are true augite andesites.

Several of the modern lava streams on the slopes of Mauna Loa are represented in the Baker collection, including those of $1843,1852,1855-56,1859,1868,1880-81,1882$, and 1887. All these are said to be of dark-colored chrysophyric rocks belonging with the second group of the crater lavas.

Rocks described by Daly.-The flow of 1852 from Mauna Loa was crossed by Daly on the trail from Kilauea toward Mauna Kea, and he describes the rock and gives an analysis. ${ }^{1}$ The rock is called an "ultrafemic olivine basalt" and it is said to be richer in olivine phenocrysts than any other lava seen by Daly in Hawaii. By the Rosiwal method the olivine contents are estimated at 32 per cent. An analysis of this olivine is given, showing 82.29 per cent of forsterite, 15.94 of fayalite, and 0.20 of tephroite, with 1.91 per cent of impurities. The groundmass is diabasic and contains plagioclase microlites, augite granules, magnetite, and probably ilmenite. The rock is vesicular but contains no glass.

The analysis of this rock is given under No. 38 in the table of analyses (p. 48). The position of the rock in the quantitative system is shown in the table facing page 56. Close chemical analogues of this lava are rare, the nearest being an olivine diabase of New Jersey and a picrite of the Crazy Mountains, Mont. (p. 76). The chrysophyric basalt of Puna (p. 43) is of very similar constitution. The term "picritic basalt" seems to express the general character of this rock, and it is so referred to in later pages.

Rocks collected in 1902.- In traveling from Kilauea through Kau and Kona to Mount Hualalai along the road I had opportunity to see several flows of Mauna Loa erupted during the last century. Most of these are represented in the collection studied by E. S. Dana, and I can in most cases only confirm his statements. In general these flows consist of olivine-plagioclase basalt of normal character.

The flow of 1.823 , crossed by the road about halfway between Kilauea and Punaluu Harbor, in Kapapala, is of the usual basaltic habit, but my specimen, taken near the eastern edge, is nearly olivine free. The rock is aphanitic, aphyric, and irregularly vesicular in subordinate degree. In thin section it appears to be made up of labradorite, augite, magnetite, and a smcky glass base, all of common basaltic habit and fabric. Olivine is very subordinate indeed. I do not know whether the flow as a whole is so poor in olivine.

Several flows from Mauna. Loa which passed between Mauna Kea and Hualalai were examined where they are crossed by the road from Kailua to Waimea. The flow of 1859 is dark resicular aphanite of normal basaltic composition. Other flows a few miles east of that of 1859 are of similar character, varying only in texture; from place to place.

Reviéw.-The lavas of Mauna Loa, erupted during the last century, are apparently all normal olivine-plagioclase basalts with the possible exception of that of 1823 , which in the single specimen examined is abnormally poor in olivine. This chrysolitic type is also represented in and about the crater of Mokuaweoweo, but many of the rocks exposed in the walls of that great caldera in 1888 are of andesitic composition, as described by Dana.

KILAUEA.

General statement.-Kilauea, perhaps the best-known basaltic volcano in the world, has been visited by a host of geologists; the history of its eruptions has been compiled by J. D. Dana, ${ }^{2}$ Dutton, ${ }^{3}$ Hitchcock, ${ }^{4}$ and Brigham, ${ }^{5}$ while the story of particular eruptions has been graphically told by many eyewitnesses. But with the exception of Dana all these writers have paid

Jour. Geology, vol. 19, p. 294, 1911.

${ }^{2}$ Charncteristics of volcanoes, New York, 1890.

8 U. S. Geol. Survey Fourth Ann. Rept., pp. 75-219, 1884.
1 Hawaii and its volcanoes, 2 d ed., Honolulu, 1911

5 Bernice Pauahi Bishop Mus. Mem., vol. 2, No. 4, pp. 379-600, 1909. 
attention to the physical phenomena only. The lavas are referred to as basaltic, and it is true that their characteristic external features give general confirmation to this classification. With few exceptions the described rocks of Kilauea have not been collected by the petrographers who have studied them. The most notable contributions to the petrography of Kilauean lavas are those by Cohen, ${ }^{1}$ Silvestri, ${ }^{2}$ and E. S. Dana. ${ }^{3}$

Chemical analyses which may be considered sufficiently reliable for petrographic discussion have been made to the number of 21 , and several others which are not satisfactory have been published. Four of the analyses are of "Pele's hair," two of "basalt obsidian," one of material collected as molten lava, and several others are of hypohyaline rocks. Obviously all these lavas can be adequately classified only by normative study of the analyses. For this reason the results of such study, detailed in the tables of norms and normative ratios, will be used in grouping the rocks for description. A more detailed study of the Kilauean lavas, with reference to their normative character, is given in a later section of this paper (p. 60).

Megascopically, the lavas of Kilauea present the usual range of textures found in any great basaltic complex. The visible variations in olivine, augite, or plagioclase phenocrysts give no ground for referring any occurrences to another group than basalt. The aphanitic and hyaline phases are relatively more abundant than at most other centers and the hyaline rocks have received so much attention from Cohen, Krukenburg, ${ }^{4}$ and E. S. Dana as to make them classic illustrations of basic if not of basaltic glasses.

As a rule the exact localities of the rocks of Kilauea of which microscopical and chemical studies have been made are not definitely stated. In general they belong, however, (1) to the lavas of the floor of Kilauea which have issued from the center of Halemaumau within the last three or four decades; (2) to the older lavas exposed in the walls of the main caldera; or (3) to fragments from the tuff breccia on the outer slopes. While none of the rocks are as old as those of most other volcanoes of the islands, it is of some interest to consider these groups separately.

Recent lavas.-Only the more recent lavas of Halemaumau, the active center of historic times, which are slowly filling the caldera of Kilauea, can now be seen, for the flows of 1880-1894 have covered those of earlier date.

Four recent lavas of docrystalline texture were described by E. S. Dana ${ }^{5}$ as "dark-colored vesicular basalts, containing chrysolite but not in large amount. My own specimens correspond to this statement. From the table of norms of the 11 rock analyses representing mostly hyaline forms of these recent magmas, it appears that they all fall in Class III, the salfemanes, and 10 of them in the perfelic order germanare, while 1 is in the quardofelic order vaalare. Seven of them are similar in that their total salic contents range only from 53 to 58.1 per cent, while three have less than 50 per cent of Sal. The rocks of dominant salic contents vary somewhat in the character of the normative feldspar. Five of them are in the alkalicalcic rang camptonase. These are of nearly the same relative abundance of albite over orthoclase, four of them belonging to the dosodic subrang camptonose (III.5.3.4) and one to the persodic ornose (III.5.3.5) but so near the line that it should be called camptonose-ornose. The other three rocks with'more than 50 per cent of salic molecules in their norms have relatively more anorthite but are, like the others, low in potash and are assigned to auvergnose (III.5.4.4-5), in which albite is greatly in excess of orthoclase. The lavas falling in auvergnose are much more normal basalts than those in camptonose.

The most femic of the lavas of Kilauea analyzed is a specimen of "Pele's hair" (No. 34). Its 41 per cent of normative salic molecules includes but 8 per cent of anorthite, owing to the low alumina. The percentage of diopside is correspondingly increased. The ratio of alkali feldspars to anorthite in the norm is 2.1:1. The holocrystalline form of this magma would necessarily have rather strongly alkalic plagioclase, and as the norm shows 0.8 per cent of quartz and as the olivine contents could not be high, the rock might be an augite andesite, not a basalt.

1 Neues Jahrb., 1880, vol. 2, pp. 23-62.

2 Com. geol. Italia Boll., vol. 19, pp. 128-147, 168-196, 1888.

3 Am. Jour. Sci., 3d ser., vol. 37, pp. 441-467, 1889.
4 Mikrographie der Glasbasalte von Hawaii, Inaug. Diss., Tubingen, 1877. 5 Am. Jour. Sci., 3d ser., vol. 37, p. 458, 1889. 
Five other recent lavas of Kilauea contain normative quartz, ranging from 0.8 to 8.5 per cent. It is plain that these lavas can have no large amount of olivine in their crystalline modes unless accompanied by free silica, and while they are so rich in anorthite as to make it probable that these varieties would here be called plagioclase basalt (olivine free), they are manifestly near to pyroxene andesites.

The lavas of Halemaumau do not contain normative nephelite in notable amount, contrasting in this respect with some of the rocks next to be considered.

The magma of 1911 has the composition given under No. 30 in the general table of analyses (p. 48). The material for this analysis was dipped from the basin of molten lava by Perret and Shepherd ${ }^{1}$ and presumably represents the general character of the magma of the present period of eruption, which has now continued for several years. This magma is ornose-camptonose and transitional also to auvergnose (III.5.3(4).4(5)). It is near the average magma of Halemaumau.

Another recent lava, thought by Day to be probably that of 1894 , has the composition shown by analysis 29 of the table, which is that of a specimen collected by Day. It is auvergnose (III.5.4.4-5) and nearly like other lavas of this group.

Rocks of the caldera walls.-Eight rocks of the walls of the caldera have been analyzed by Silvestri, ${ }^{2}$ giving interesting evidence of much more diversity in chemical composition than would be suggested by the megascopic aspect of the rocks themselves. No specific data as to locality or character of the rock masses are given. As clastic rocks are rare at Kilauea, it may be plausibly inferred that Silvestri's analyses represent lava flows of the upper 200 to 300 feet of Kilauea, erupted before the present caldera was formed.

On studying the analyses by means of the norms, it at once appears noteworthy that they are nearly all of rocks more salic than any of the more recent lavas. Three of them fall in the dosalane class, although two of these are very near the salfemane line. The small amount of olivine and the general character of one of these varieties led Silvestri to call it augite andesite, while another one is described as intermediate between andesite and basalt, the scanty olivine alone preventing reference to andesite. His augite andesite contains, however, 6 per cent of normative olivine. (See No. 11 in table of norms, p. 51.)

The table of norms shows that two of the rocks under discussion belong to the subrang andose and one to salemose. One of the former is a camptonose-andose and is thus nearly related to several other lavas of Kilauea. It is rather high in orthoclase and olivine.

The two remaining dosalanes are notable as possessing normative nephelite and olivine, one of them carrying a sufficient amount of nephelite (9.7 per cent) to put it in the lendofelic order. This rock is also remarkable, if the analysis is correct, for its orthoclase content (16.7 per cent), which exceeds that of albite and is surpassed in but two known rocks of Hawaii,namely, the soda trachytes. Altogether these rocks approach the essexitic composition shown by the lavas of Haleakala, already described.

The next interesting phase of these rocks is represented by two hornblende-bearing types of kilauose (III.5.2.4). The characteristic chemical feature of these magmas is their relatively high alkali feldspars and low anorthite. One of them is near the lendofelic order in which monchiquose (III.6.2.4) is the corresponding subrang. Both rocks are also near to the essexose of Haleakala, as a glance at the norms will show. Hornblendic rocks are very rare in Hawaii, and these two types have both normative and modal peculiarities not expressed in calling them common basalts.

Two of Silvestri's "basaltoids" are camptonose of nearly the same composition. With the camptonose-andose these form a group of olivine-plagioclase basalts of no unusual features except a general high ratio of alkali feldspar to anorthite.

The remaining rock is a more calcic plagioclase basalt, but so high in silica that its norm shows 3.4 per cent of quartz. It is chemically almost identical with the lava of 1883 , already mentioned. Owing to the rarity of phenocrysts of olivine, augite, and plagioclase, which Silvestri considers characteristic of true basalts, he proposes for this rock the name kilaueite.

1 Day, A. L., and Shepherd, E. S., Geol. Soc. America Bull., vol. 24, p. 285, 1913.

2 Com. geol. Italia Boll., vol. 19, pp. 128-147, 168-196, 1888. 
The six rocks from the walls of Kilauea described by E. S. Dana ${ }^{1}$ are olivine-plagioclase basalts with little in the brief descriptions to aid in correlating them with special types analyzed by Silvestri. One of them, from Waldrons Ledge, is unusually rich in olivine and is the most mafic lava of the volcano now known.

Fragments in the tuffs.-The slopes surrounding the caldera have a coating of volcanic ashes, in some layers of which there are many fragments of basaltic character. The collection studied by E. S. Dana contained specimens of 11 such ejected rocks, from the rim of the caldera, especially on the west side. I collected three representatjve types from loose fragments near the triangulation station on the north rim. The pyroclastic deposits are heaviest and most extensive to the southwest of the main caldera. J. D. Dana ${ }^{2}$ referred this material to the last important explosive eruption of Kilauea, in 1789 or 1790 , but Hitchcock ${ }^{3}$ has pointed out that the mass of the tuff-breccia is larger than is plausibly referable to that outburst, of which accounts, obtained from the natives, have been published.

Whatever the date of eruption may be, the interest attaching to these materials in the present review lies mainly in the evidence they afford as to the petrographic character of Kilauean lavas of older date than any flows now visible. J. D. Dana, ${ }^{4}$ who examined the tuff-breccia with care in 1887, has briefly described the megascopic appearance of the rock fragments as follows:

The ejected stones vary in size up to several cubic feet. Those of 1 or 2 cubic feet are common, many are 20 to 30 , and one seen by the author on the west side of Kilauea measured 100 cubic feet and must have weighed over 8 tons. Part are ordinary volcanic scoria, but the most of them consist of the more solid basalt, sparingly vesicular, and many of the larger are of a light-gray kind, very slightly vesicular or hardly at all so, very sparingly chrysolitic, and frequently having on the worn exterior a faint banded appearance from alternating variations in compactness of texture. Another kind varies in color from faintly reddish to gray, is more or less vesicular, and contains a large amount of chrysolite.

E. S. Dana's description ${ }^{5}$ of material collected by his father from fragments thus described shows that there is considerable variety among them. Some are said to be coarsely granular rocks rich in olivine and labradorite and presumably containing augite and iron ore, though these are not mentioned. Other light-gray lavas contain little olivine and seem to belong to the group of rocks near to pyroxene andesite, of which several examples have been given. Some are vesicular basalts with prominent olivine.

Of the three specimens of ejected fragments collected by me, one is a common vesicular olivine-plagioclase basalt similar to some of the recent flows from Halemaumau. Another is a light ash-gray, megascopically aphyric aphanite with a few minute pores containing feldspar and ore tablets. This is no doubt like certain rocks described by E. S. Dana, the vesicles of which have tablets of labradorite and ilmenite. This rock is a very even grained, almost holocrystalline mixture of augite, labradorite, and magnetite particles of pronounced micro-ophitic fabric. Olivine is rare and the rock is essentially an aphanitic diabase.

The third fragment of my collection is a dark-gray, very dense perpatic aphanophyre. Its phenocrysts are partly discernible by the naked eye, and a hand lens shows some of them to be olivine, while the microscope proves the majority to be augite. There are a few microphenocrysts of labradorite and scattered groups of the three silicates. The groundmass is a holocrystalline granular mixture of straw-yellow augite, in almost equidimensional grains less than 0.01 millimeter in diameter, plagioclase laths 0.02 by 0.006 millimeter in average dimensions, and magnetite dust. Plagioclase seems also to be the irregular matrix of the mass. No olivine has been recognized in the groundmass.

As this rock seemed to be more basic than most Kilauea basalts and poor in olivine it was submitted to analysis, with the result given in column 33 of the table of analyses. It proves to belong in the subrang auvergnose (III.5.4.4-5) and to be considerably more basic than any lava analyzed by Silvestri. It has $\frac{\mathrm{Sal}}{\mathrm{Fem}}=\frac{42.9}{56.6}$ and is in this ratio near the "Pele's hajr" analyzed by Cohen; but its normative plagioclase is much more calcic than that of the glass.

1 Am. Jour. Sci, 3d ser, vol, 37, p. 459, 1889

2 Characteristics of volcanoes, p. 41, New York, 1890.

${ }^{8}$ Hawaii and its volcanoes, 2d ed., p. 168, Honolulu, 1911.
4 Op. cit., p. 44.

5 Op. cit., p. 460 . 
The norm shows 0.8 per cent of quartz, and naturally there is neither olivine nor nephelite. The rock is either a plagioclase basalt (olivine poor) or an olivine-bearing augite andesite.

Gabbro of the Uwekahuna "laccolith."-Daly". has described the rock of an apparently intrusive mass, a section of which is exposed in the caldera wall near the Uwekahuna triangulation station, as "porphyritic gabbro." The facts of occurrence stated by Daly do not, it seems to me, demonstrate the intrusive character of this body, said to be 20 meters thick and 160 meters wide. If intrusive the magma was injected into the thin upper zone of the volcano, while presumably some form of conduit led to the surface near by.

The rock is characterized by numerous olivine phenocrysts which reach a maximum diameter of about 4 millimeters. The groundmass is millimeter-grained as to its augite and labradorite $\left(\mathrm{Ab}_{2} \mathrm{An}_{3}\right)$. The grain is thus not much coarser than that of many basaltic flows.

The modal percentage composition of the rock is estimated by Daly at olivine 40 , augite 31 , labradorite 27, magnetite and ilmenite 1.7, and apatite 0.3 . The analysis of this rock made by Steiger, for Daly, is given under No. 42 of the table of analyses (p. 48). It is very clear that this porphyritic gabbro is almost identical in composition with the chrysophyric basalt of Puna, erupted in 1840, which is described below. It is next to the most femic rock of Hawaii thus far analyzed, and is in general near wehrlite in chemical composition, as Daly has pointed out. Division XIV of the table of analogues (p. 77) gives analyses of several analogues of this gabbro and of the basalt of Puna.

Summary.-The lavas of Kilauea exhibit much variety in chemical composition, but are predominantly olivine-poor basalts of the subrangs camptonose (III.5.3.4) or auvergnose (III.5.4.4-5). A number of the analyzed rocks have quartz in their norms. The gabbro of the Uwekahuna "laccolith" and the chrysophyre of Waldrons Ledge, noted by E. S. Dana, show that very femic magmas have also appeared at times. The lavas of the outer caldera wall show greater variation than those of Halemaumau, and there are certain apparently persistent differences between these groups of lavas (pp. 60-62). No very salic magmas are known from Kilauen.

PUNA.

The district called Puna, including the southeastern point of Hawaii and extending on the west nearly to the crater of Kilauea, is characterized by a number of cones and pit craters. Most of these lie in a narrow belt extending east-northeastward nearly the entire length of Puna. Owing to their evident connection with Kilauea, shown by activity at several points in 1840 , culminating in a lava flow some 12 miles long that reached the sea at Nanawale, these minor cones of Puna are considered by Brigham ${ }^{2}$ and other writers "a part of the Kilauea system."

Little is known as to the petrographic character of the lavas of Puna. E. S. Dana ${ }^{8}$ refers to the highly "chrysolitic character" of the Nanawale flow of 1840 and to the small amount of olivine in the crystalline lavas of Makaopuhi, a cone in the zone referred to, near Kilauea.

The an flow of 1840 is represented in my collection by specimens taken near the tuff "sand hills" formed by explosive action where the lava plunged into the sea, about 20 miles southeast of Hilo. This olivine-rich basalt is so different from most known Kilauean lavas that it has been analyzed and will be described in some detail.

The rock is a dark-gray chrysophyre and is variously vesicular in different parts of the flow. The specimen analyzed has abundant rounded but irregular vesicles, reaching a maximum diameter of about 1.5 centimeters and occupying about one-third of the space. No secondary minerals are present in the cavities. It seems to the unaided eye that about half the rock must be olivine, but accurate estimate is impossible because of the serial gradation from crystals 1 centimeter in diameter down to those identifiable only with the microscope. The olivine is very fresh, most of it exhibiting the characteristic clear yellowish green, while many of the larger crystals display brilliant iridescent colors. No other phenocrysts occur.

The microscope shows the groundmass to be nearly holocrystalline and of very simple composition. Besides the smaller olivine grains it is made up of augite $>$ labradorite $>$ magnetite,

1 Jour. Geology, vol, 19, pp. 291-294, 1911.

3 Bernice Pauahi Bishop Mus. Mem., vol. 2, No. 4, pp. 379-600, 1909.

3 Am. Jour. Sci., 3 d ser., vol. 37 , p. 46i1, 1889 . 
with obscure opaque or dark globulitic interstitial material that plays the part of glassy base, though no actual glass has been seen. Augite occurs in grains and irregular prismoids less than 1 millimeter in diameter. The largest labradorite microlites do not exceed 0.5 millimeter in length. The maximum extinction of the labradorite microlites indicates a rather highly calcic variety. No orthoclase or nephelite has been detected. Magnetite is much obscured by the ferritic residual material in which it is embedded.

The analysis, by George Steiger, and the norm calculated from it are as follows:

Analysis and norm of olivine-rich basalt from Puna.

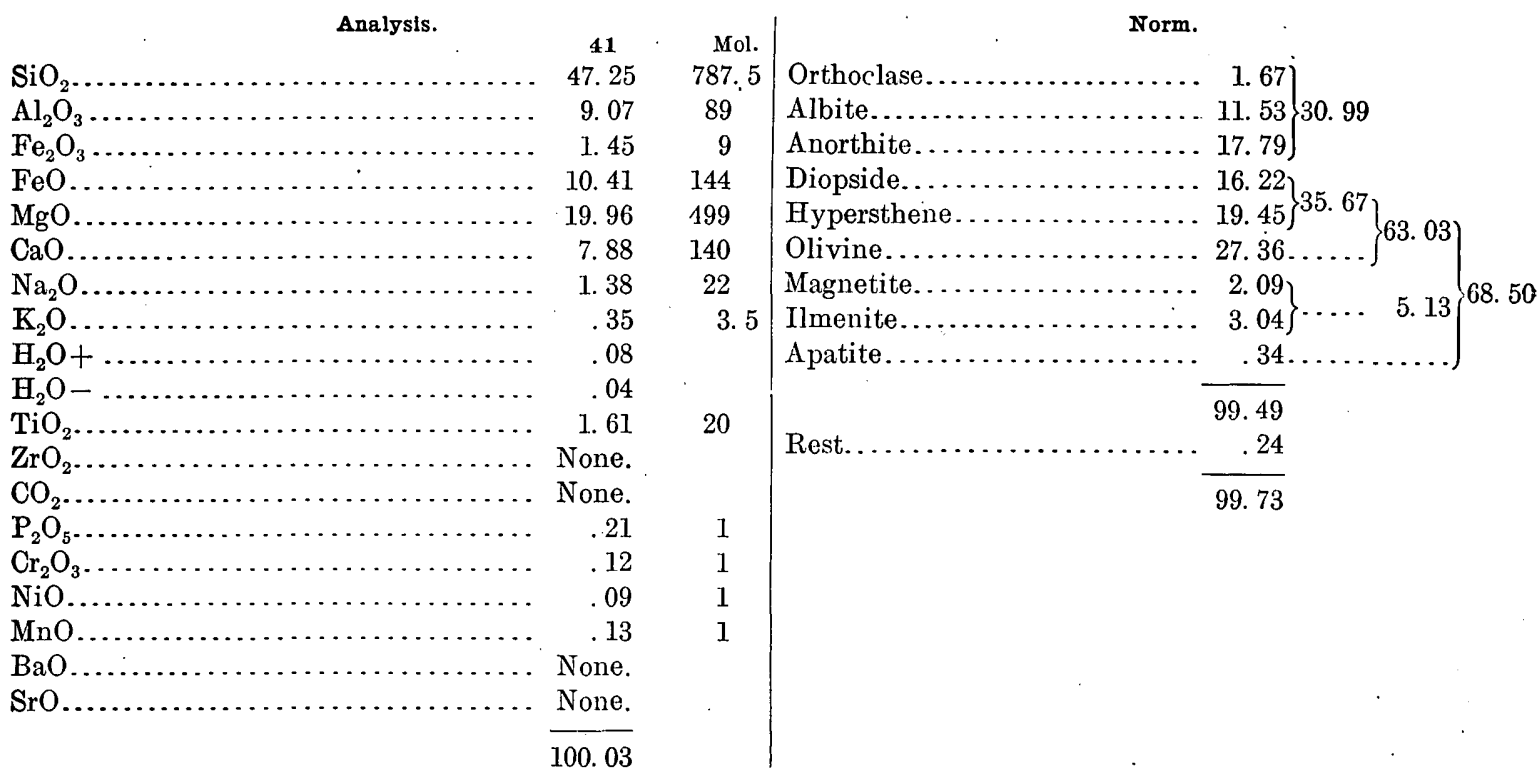

The subordinate rôle of the feldspars and the abundance of magnesia in pyroxene and olivine make a distinction from common basalt desirable, and the term picritic basalt is used for this purpose. The Nanawale flow is notably similar in composition to the porphyritic gabbro of Kilauea, thought by Daly to be an intrusive. The analyses and norms of these rocks and of several analogous rocks are compared in Division XIV of the table of analogues (p. 77).

The quantitative classification of the rock is shown from the accompanying ratios:

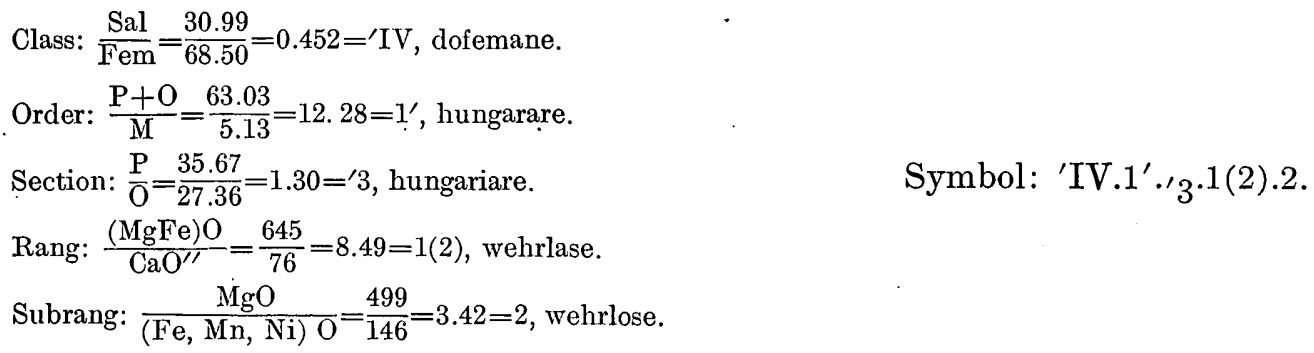

\section{GENERAL DisCUSSION OF haWAitan lavas.} INTRODUCTION.

The islands of the Hawaiian Archipelago represent the higher summits of a chain of .mountains, mainly submarine, known to extend for about 1,800 miles in a general northnorthwesterly direction. Soundings have shown the existence of many other mountains in addition to those whose summits now project above sea level. The ocean floor from which these mountains rise is more than 20,000 feet below the surface of the sea, but the configuration of the sea bottom is largely a matter of conjecture. Dana and others have supposed that deep troughs exist on either side of the island chain. 
All the known islands of this midocean range are volcanic except for insignificant surface deposits, largely of coral reef or sand, and the volcanoes appear to be situated along a line of weakness in the submarine crust. The date at which eruptions began and the duration of the period of eruption are alike questions which can not be answered. It seems reasonable to assume that the volcanic activity has continued during all of Tertiary time, at least, and may have begun in the Mesozoic era. J. D. Dana ${ }^{1}$ has said that "There is reason for believing that the fires along the Hawaiian line broke out all together at some time in the long past, but only Hawaii has kept on piling up lava streams from that remote time of outbreak until now, and hence has come the altitude of these lofty volcanic mountains of the Pacific." But it is certainly possible that the earliest eruptions occurred at the west end of the zone, and that in general there has been a progression in the appearance of activity at centers toward the southeast.

From the study of certain snails which are widely distributed among the islands, Pilsbry ${ }^{1}$ has advanced the hypothesis that the present islands are the result of a subsidence which affected a large area, submerging the lower lands formerly connecting them.

The Hawaiian Archipelago appears, then, to form a very simple petrographic province. Its igneous rocks are clearly comagmatic or consanguineous, to use terms in current use. The region appears to be one especially suited to furnish the means of testing several broad generalizations of the day regarding the genetic relations of igneous rocks-generalizations based, as it seems to me, on a rather hasty survey of a great mass of undigested or disordered material from all over the earth.

A study of Hawaiian rocks will now be undertaken for the light it may throw on some of these important questions-first, the broad geographic problem involved in the original distinction of the Atlantic and Pacific branches or kindred of rocks; second, the idea of restricted genetic associations of two great series of igneous rocks, whether considered in connection with differentiation from various parent magmas or with tectonic history; third, the distinction itself, often spoken of as natural and of fundamental genetic or systematic importance, between the rock series variously designated as Atlantic and Pacific, alkali and subalkali, alkali and calc-alkali, or alkalic (alkaline) and calcic; fourth, the process of differentiation.

\section{CHARACTERISTICS OF THE ROCKS.}

\section{MINERAL COMPOSITION.}

General review.-Plagioclase, augite, olivine, and magnetite are the most important minerals in a great majority of Hawaiian rocks, and in many lavas no other constituents of note are present. The quantitative relations of these components vary greatly, as has been shown in the preceding descriptions.

Further variety is produced by the appearance of nephelite and melilite in a considerable group of younger rocks and of bronzite in the basalts of Oahu. The potash feldspar molecule is an almost constant constituent, as shown by the analyses, but it is rarely developed in recognizable form and is presumably an occult element in the plagioclase.

The alferric silicates, hornblende, and biotite are conspicuous by their absence, as a rule. The former is mentioned by Silvestri as occurring in two or three lavas of Kilauea but has not been noted by other petrographers. Biotite was observed only in insignificant development in the groundmass of one basalt of Kauai.

Ilmenite is possibly a companion of magnetite in some rocks, but the high content of $\mathrm{TiO}_{2}$ revenled by analysis is principally concealed in augite or in titanomagnetite. Only rarely is its presence revealed by a violet color of the augite.

The simplicity in modal composition indicated by this review deserves further scrutiny if it is to be used as the basis for an adequate classification and nomenclature in the qualitative system. This is particularly true as to the composition of the plagioclase and the role of both occult and abnormative constituents.

Plagioclase.-Most published descriptions of Hawaiian rocks give little definite information concerning the observed plagioclase. In fact, many of the lavas examined are hypohyaline, 
several of those analyzed are perhyaline, and not a few are without any noted crystals, as in the specimens of "Pele's hair." Moreover, while a part of the plagioclase is in distinct phenocrysts of labradorite or andesine, a larger part of more sodic character is present in microlites of the groundmass or in potential form in residual glass.

As it is desirable to classify these rocks, even in the qualitative system, by their real rather than their apparent characters, it is necessary to take into account the average composition of the plagioclase, which is shown, as closely as is possible, by the table of norms. Only by such a method can these lavas be systematically compared with their granular equivalents. Thus the "Pele's hair," No. 34 of the table, must certainly be considered as practically a hyaline phase of the kauaiite or olivine-bearing oligoclase gabbro (No. 26), and not simply a basaltic glass.

The approximate amount and character of the normative plagioclase may be readily seen by a glance at the percentages of albite and anorthite in the table of norms. From those figures the average or normative composition of the plagioclase may be taken as follows:

Albite in No. 2.

$\mathrm{Ab}_{17} \mathrm{An}_{1}$ in No. 1.

Oligoclase in Nos. $3,6,13,26$, and $34=5$.

Andesine in Nos. $4,5,7,8,10,12,15,16,18,25,27,28,19,32,23$, and $30=16$.

Labradorite in Nos. $9,11,17,24 ; 21,20,22,33,29,14,31,35,36,38,41$, and $42=16$.

Bytownite in No. 39.

It further appears that in 27 rocks the normative plagioclase has a composition between $A b_{2} A n_{1}$ and $A b_{1} A n_{2}$ with an average close to $A b_{1} A n_{1}$.

Now, several factors affect the agreement between this normative plagioclase and the average composition of the modal plagioclase. On the one side are two factors which tend to make the alkalic components more prominent in the mode than they are in the norm. Orthoclase is present in the mode in such subordinate amount that presumably it has been drawn with albite into the plagioclase, at least to a considerable extent. There is no biotite, and rarely hornblende, to take up potash, and potash is relatively insignificant in most analyzed augites.

Albite is doubtless directly increased over the normative percentage wherever olivine is abnormatively developed in rocks corresponding to those whose analyses show normative nephelite. This has been discussed in another place (p. 55).

The influence of these factors to raise the alkalic element of the modal plagioclase is partly offset or entirely counterbalanced by the entrance of sodic and aluminous molecules into the alferric augite. The composition of the augite of these rocks is unknown. But there is rarely evidence of the acmite molecule, and it is not to be overlooked that normative anorthite is perhaps as likely as the albite to furnish alumina for the augite.

On reviewing these factors, I regard it as probable that the average modal plagioclase of the Hawaiian basalts is at least as rich in the alkalic element as the normative plagioclase, figured from the percentages of albite and anorthite.

Lenads.-The prominence of nephelite in several rocks of Oahu, Maui, and Kauai has been sufficiently emphasized in describing them. The normative nephelite of many other rocks is usually not to be detected, and its significance has been discussed (p. 54) under the head "Relations of norm and mode." But, although so elusive, the potential nephelite, which might undoubtedly become modal under conditions of consolidation such as many rocks of equivalent composition have experienced, is an element to keep in mind in systematic discussion of the Hawaiian lavas. Leucite is prominent in the norms of three rocks of Oahu, but it has not been detected in the mode.

Quartz, tridymite, and cristobalite.-Free silica in any form has been recognized in very few Hawaiian lavas, but the norms point conclusively to the fact that many of them are, potentially at least, equivalents of quartz-bearing rocks of other regions. Certain lavas are very near to the quartz basalt of Mount Shasta in composition, and others correspond to quartz-bearing granular rocks. Tridymite was found in several rocks in very obscure development, quite unlike the aggregates which are so common in andesites and dacites. The various possible forms of free 
silica are to be regarded as of much importance in many Hawaiian lavas, as showing general petrographic affiliations, and they should be looked for with due care in all holocrystalline basalts of low olivine contents and may occur in those rich in olivine, as proved by the basalt of Olokele Canyon, in Kauai.

Augite and olivine.-The augite of these rocks has common characters of basaltic augite. It is colored by the æoirite molecule in few rocks and is never very strong brown in color. It must have the general composition of the combined diopside and hypersthene molecules of the norms modified by the entrance of some soda and alumina calculated as belonging to albite and governed also by the different ratios between the $\mathrm{FeO}$ and $\mathrm{MgO}$ silicates entering respectively into augite and olivine.

Daly ${ }^{1}$ has published the following analysis, by George Steiger, of olivine from the basic basalt of Mauna Loa, flow of 1883:

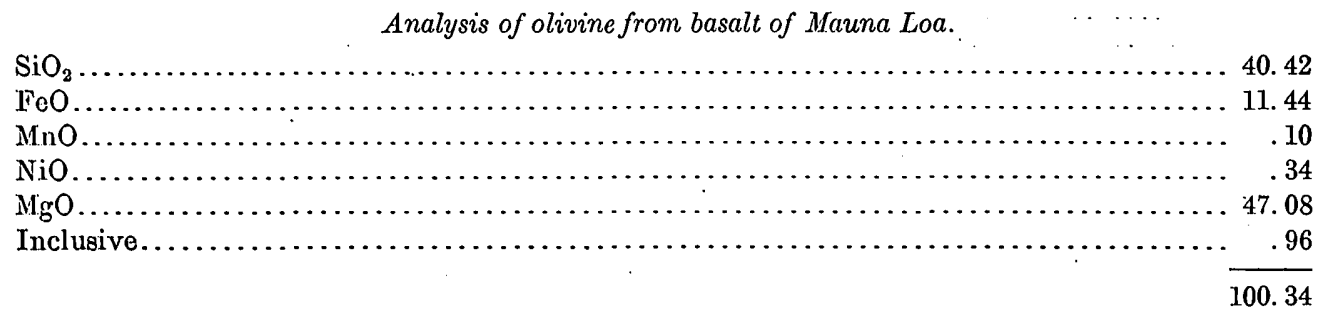

This shows about 5 forsterite to 1 fayalite. The norm of this basalt (No. 38) has olivine of the composition of about 3 forsterite to 1 fayalite. This goes to show that for this rock the augite is richer in iron metasilicate and the olivine richer in magnesian orthosilicate than the corresponding normative molecules. Very probably this relation holds good for other rocks of Hawaii.

\section{CHEMICAL COMPOSITION.}

While knowledge of Hawaiian lavas is clearly very incomplete, many varieties have been identified by microscopical examination, and there exists a really notable series of chemical analyses, so that the general character of the rocks may be seen. This character will be brought out by tables of analyses, norms, and ratios, by a diagram (Pl. IV), and by discussion of the points of most importance.

Analyses of Hawaiian lavas.

\begin{tabular}{|c|c|c|c|c|c|c|c|c|c|c|c|}
\hline & 1 & $\mathbf{2}$ & 3 & 4 & 5 & 6 & 7 & 8 & 9 & 10 & 11 \\
\hline 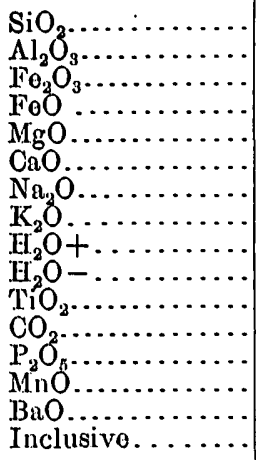 & $\begin{array}{r}61.69 \\
17.33 \\
5.30 \\
.07 \\
.16 \\
1.05 \\
7.47 \\
3.47 \\
1.93 \\
.42 \\
.67 \\
. . .3 \\
.05 \\
.21 \\
.07 \\
\text {. } .21\end{array}$ & $\begin{array}{r}62.19 \\
17.43 \\
1.65 \\
2.64 \\
.40 \\
.86 \\
8.28 \\
5.03 \\
.39 \\
.14 \\
.37 \\
.02 \\
.14 \\
.32 \\
.03 \\
\text { c. } 04\end{array}$ & 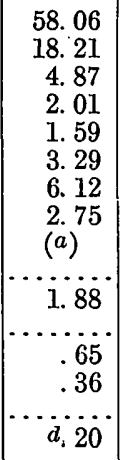 & $\begin{array}{r}49.55 \\
17.78 \\
4.65 \\
5.89 \\
2.49 \\
7.01 \\
6.12 \\
2.29 \\
.34 \\
.29 \\
2.09 \\
\text { None. } \\
1.10 \\
.28 \\
.05 \\
e .13\end{array}$ & $\begin{array}{r}50.92 \\
17.59 \\
3.80 \\
6.69 \\
3.90 \\
6.97 \\
4.28 \\
1.86 \\
.79 \\
.35 \\
2.55 \\
\ldots . . \\
.40 \\
.20 \\
\ldots \ldots . . \\
\ldots \ldots\end{array}$ & $\begin{array}{r}51.26 \\
16.74 \\
2.92 \\
7.11 \\
2.80 \\
6.61 \\
5.86 \\
2.25 \\
.42 \\
.26 \\
2.57 \\
\text { Trace. } \\
.81 \\
.23 \\
.10 \\
\text { f. } 09\end{array}$ & $\begin{array}{r}49.73 \\
16.39 \\
7.58 \\
3.98 \\
4.06 \\
7.17 \\
4.12 \\
1.93 \\
.54 \\
.81 \\
3.05 \\
\text { None. } \\
.84 \\
.23 \\
.03 \\
g .07\end{array}$ & $\begin{array}{r}46.30 \\
17.95 \\
6.21 \\
6.79 \\
3.67 \\
8.17 \\
3.92 \\
.89 \\
(a) \\
\ldots \ldots .35 \\
\ldots \ldots \\
.53 \\
.26 \\
\ldots . .28 \\
h .28\end{array}$ & $\begin{array}{r}48.71 \\
18.87 \\
3.18 \\
8.00 \\
4.85 \\
9.87 \\
4.15 \\
1.52 \\
\ldots \ldots \ldots \\
\ldots \ldots . . \\
\ldots \ldots 1 \\
\ldots \ldots . . \\
\text { Trace. } \\
\text { Trace. } \\
\ldots \ldots . . . \\
\ldots \ldots . . .\end{array}$ & $\begin{array}{c}49.01 \\
16.29 \\
7.61 \\
4.89 \\
3.62 \\
9.79 \\
3.82 \\
.80 \\
(a) \\
\ldots \ldots .9 \\
3.93 \\
\ldots \ldots \\
.49 \\
.27 \\
\ldots \ldots . .2 \\
i .32\end{array}$ & $\begin{array}{r}50.16 \\
17.97 \\
2.23 \\
6.25 \\
4.70 \\
11.85 \\
3.50 \\
2.80 \\
.90 \\
\text { Trace. } \\
\ldots \ldots . \\
\text { Trace. } \\
.30 \\
\ldots \ldots . . . \\
\ldots \ldots . .\end{array}$ \\
\hline Sum...... & 100.10 & 99.93 & 99.99 & $\ldots \ldots$ & 100.30 & 100.03 & 100.53 & 100.32 & 100.96 & 100.84 & 100. 66 \\
\hline $\begin{array}{l}\text { a Analysis of } \\
\text { b } \mathrm{ZrO}_{2}, 0.16 \\
\text { c } \mathrm{ZrO}_{2}, 0.04 \\
\text { d } \mathrm{CuO}_{0}, 0.10 \\
\text { e } \mathrm{ZrO}_{2}, 0.01\end{array}$ & $\begin{array}{l}3,0.05 ; \\
S_{2}, 0.03 ;\end{array}$ & 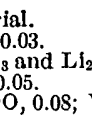 & ${ }_{2} \mathrm{O}_{3}, 0.015$. & & & & \multicolumn{5}{|c|}{ 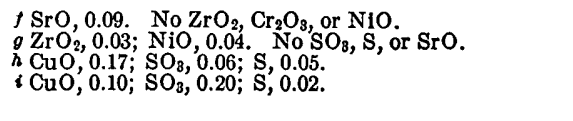 } \\
\hline
\end{tabular}

1 Jour. Geology, vol. 19, p. 295, 1911. 
Analyses of Hawaiian lavas-Continued.

\begin{tabular}{|c|c|c|c|c|c|c|c|c|c|c|c|}
\hline & 12 & 13 & 14 & 15 & 16 & 17 & 18 & 19 & 20 & 21 & 22 \\
\hline $\mathrm{SiO}_{2}$ & 45.61 & 49. 45 & 51.77 & 47.63 & 48.04 & 47. 61 & 45.79 & 49. 88 & 48.82 & 49.20 & 50.75 \\
\hline $\mathrm{Al}_{2} \mathrm{O}_{3}$. & 15. 98 & 13. 97 & 15. 66 & 15. 02 & 14. 62 & 16. 09 & 15.09 & 13. 79 & 15. 22 & 14. 90 & 1.6. 54 \\
\hline $\mathrm{Fe}_{2} \mathrm{O}_{3}$ & 8.25 & 8. 10 & 8. 46 & 8. 15 & 9. 18 & 7. 00 & 5. 34 & 9. 65 & 5. 72 & 4. 51 & 2. 10 \\
\hline $\mathrm{FeO}$. & 11. 60 & 11. 17 & 6. 54 & 10. 40 & 11. 68 & 10. 60 & 5. 58 & 2. 61 & 9.65 & 12.75 & 7. 88 \\
\hline $\mathrm{MgO}$. & 3.75 & 1. 90 & 4.95 & 3.50 & 2. 17 & .3 .10 & 5. 92 & 6. 12 & 4. 55 & 3. 90 & 7.65 \\
\hline $\mathrm{CaO}$. & 6. 42 & 5. 92 & 9. 56 & 6.87 & 7. 66 & 8. 15 & 10. 21 & 9. 59 & 10.40 & 9.20 & 11. 96 \\
\hline $\mathrm{Na}_{2} \mathrm{O}$ & 3. 50 & 5. 05 & 2. 17 & 4. 92 & 4. 00 & 2. 98 & 3. 67 & 3. 30 & 2. 10 & 1. 96 & 2. 13 \\
\hline & 1.82 & 1. 75 & .96 & 1. 80 & 1. 28 & 1. 15 & .90 & .17 & .90 & .95 & .56 \\
\hline & .27 & 1. 19 & & .30 & & .70 & (a) & $(a)$ & None. & .10 & .35 \\
\hline & 1. 15 & Trace. & & .12 & Trace. & .39 & 3. 25 & 3.97 & 1. 16 & 1. 72 & $\cdots$ \\
\hline $\mathrm{P}_{2} \mathrm{O}_{5}$ & .72 & .16 & & .08 & .45 & Trace. & .29 & .26 & Trace. & .42 & $\ldots$ \\
\hline $\mathrm{MnO}$ & 1. 20 & .85 & .82 & .80 & 1. 91 & 1. 72 & .49 & 67 & .67 & .28 & \\
\hline I 1 & & & & & & & $b 2.72$ & & & & \\
\hline & & & & & & & & & & & \\
\hline & 100.27 & 99.51 & 100.89 & 99.59 & 100.99 & 99. 49 & 99.25 & 100.26 & 99. 19 & 99.89 & 99.92 \\
\hline
\end{tabular}

$a$ Analysis of ignited material.

$b \mathrm{SO}_{3}, 2.54 ; \mathrm{CuO}, 0.1 \mathrm{~s}$.

\begin{tabular}{|c|c|c|c|c|c|c|c|c|c|c|c|}
\hline & 23 & 24 & 25 & 26 & 27 & 28 & 29 & 30 & 31 & 32 & 33 \\
\hline & 53.81 & 50.76 & 49.80 & 45.81 & 51.41 & 51.63 & 50.07 & 49. 74 & 48. 99 & 51. 12 & 50.03 \\
\hline A & 13. 48 & 14. 75 & 13. 76 & 11. 90 & 12. 92 & 1.2. 10 & 13. 32 & 12.36 & 13. 73 & 10.09 & 1.2. 10 \\
\hline$e_{2}$ & 3: 02 & 2.89 & 3. 09 & 4. 62 & 2.87 & 8. 67 & 1. 92 & 1. 64 & 1. 60 & 5.35 & 2. 10 \\
\hline ( & 7. 39 & 9.85 & 11. 97 & 8. 09 & 9. 29 & 3. 10 & 9.2 & 10.08 & 10. & 8. 59 & 9. 97 \\
\hline$\alpha$ & 6.46 & - 6.54 & 5.02 & 5. 39 & 5.45 & 9.40 & 8.0 & 8.83 & 13. & 9.6 & 9. 57 \\
\hline $\mathrm{C}$ & 10. 34 & 11.05 & 10. 25 & 10.67 & 11. 46 & 9.17 & 10. 64 & 10.88 & 7. 34 & 9. 72 . & 10.58 \\
\hline $\mathrm{Na}_{2}$ & 3.23 & 2.70 & 3.00 . & 4. 2 & 2. 92 & 3. 10 & 2. 16 & 2. 45 & 1. 62 & 3. 38 & 2. 01 \\
\hline $\mathrm{K}_{2} 0$ & .64 & .88 & 1. 15 & 1. 40 & .70 & .30 & .45 & .55 & .27 & .56 & \\
\hline & .57 & & & .53 & .32 & & 49 & .17 & 27 & 1.31 & \\
\hline $\mathrm{F}$ & .01 & & & .47 & & & .22 & .05 & .10 & & \\
\hline iO & 2. 01 & $\cdots$ & .95 & 4.05 & 2.61 & 2. 47 & 2. 70 & 2.49 & 1. 73 & & 2.57 \\
\hline & $\cdots$ & & $\cdots$ & None. & $\cdots$ & 6 & None. & None. & .24 & $\cdots$ & \\
\hline & & $\cdot 41$ & 10 & 2.20 & 16 & $\cdot 30$ & .20 & .41 & $\cdot 13$ & $\cdots$ & 2 \\
\hline & & & & 04 & & & & & .20 & & \\
\hline Inclusive & & & & $a .03$ & & & b. 28 & c. 33 & d. 17 & & \\
\hline Sum. & 100.95 & 100.09 & 99.31 & 99.65 & 100.11 & 101.08 & 99.97 & 1.00 .08 & 100.38 & 99.80 & 100.22 \\
\hline
\end{tabular}

$a \mathrm{~S}, 0.03$ : trace of $\mathrm{SrO}$. No $\mathrm{ZrO}_{2}, \mathrm{SO}_{3}, \mathrm{Cr}_{2} \mathrm{O}_{3}$, or $\mathrm{Li}_{2} \mathrm{O}$. Part of titanium may be present as $\mathrm{Ti}_{2} \mathrm{O}_{3}$, affecting figures for $\mathrm{Fe}_{2} \mathrm{O}_{3}, \mathrm{FeO}_{\text {, and }} \mathrm{TiO}_{2}$. $b \mathrm{Cl}, 0.08 ; \mathrm{S}, 0.11 ; \mathrm{Cr}_{2} \mathrm{O}_{3}, 0.05 ; \mathrm{NiO}, 0.04$; traces of $\mathrm{SrO}$ and $\mathrm{MoO}_{3}$. No $\mathrm{ZrO}_{2}, \mathrm{SO}_{3}, \mathrm{~F}$, or $\mathrm{V}_{2} \mathrm{O}_{3}$ $c \mathrm{Cl}, 0.10 ; \mathrm{S}, 0.04 ; \mathrm{Cr}_{2} \mathrm{O}_{3}, 0.04, \mathrm{~N}$,

\begin{tabular}{|c|c|c|c|c|c|c|c|c|c|c|}
\hline & 34 & 35 & 36 & 37 & 38 & 39 & $\mathbf{4 0}$ & 41 & 42 & 43 \\
\hline & 50.82 & 45. 48 & 36.85 & 35.86 & 48. 57 & 42.99 & 36.34 & 47.25 & 46.59 & 37.50 \\
\hline & & 11. & & & 10. & & & & & 9. 12 \\
\hline & 7.3 & 1. 98 & 13. 9 & 7.8 & 2. & 3.01 & & & & 5. \\
\hline & 7. 0 & 9.8 & 6.5 & 8.0 & 9.4 & 10. 28 & 10. & 10.4 & 10. & 8.8 \\
\hline & 7. 2 & 13. 28 & 10.73 & 9.7 & 17. 5 & 14. 61 & 10. & 19. & & 13. 7 \\
\hline & 11.6 & 10.9 & 9.0 & 12. 0 & & 12. & 13. & & & 13. 8 \\
\hline $\mathrm{Na}$ & 3.06 & 2.21 & 4. 1 & 6.2 & 1. 5 & 1. 40 & & 1.3 & 1.3 & 2. 6 \\
\hline $\mathrm{K}_{2} \mathrm{O}$ & 1. 02 & .77 & .79 & 1. 9 & .3 & .5 & 1. & .35 & .2 & \\
\hline $\mathrm{H}-\mathrm{O}$ & 1.74 & .74 & $(a)$ & $(a)$ & .3 & 1. 10 & 1.0 & .04 & 3 & 2. 3 \\
\hline $\mathrm{H}_{2} \mathrm{C}$ & 1.74 & .23 & (क) & (w) & .1 & .82 & .1. & .0 & .0 & 1. 0 \\
\hline TiO & $\ldots$ & 1.90 & 4.05 & 2.90 & 1. 48 & 2.52 & 2.87 & 1. 61 & 1.83 & 3. 2 \\
\hline & & None. & & & None. & None. & .15 & None. & None. & .2 \\
\hline$P 0 O$ & & .25 & 1. 25 & 1.08 & . 19 & .29 & 1. 02 & .21 & .11 & \\
\hline $\operatorname{lnc}$ & .38 & .04 & 1. 13 & .39 & .16 & .17 & $: 20$ & .13 & .18 & \\
\hline Inclusive & & $\begin{array}{r}\text { Trace. } \\
\text { b. } 19\end{array}$ & c. 28 & $d 1.92$ & e. 18 & $\begin{array}{l}\text { None. } \\
\text { f. } 12\end{array}$ & g. 04 & h. 21 & $i .25$ & j. 28 \\
\hline Sum.. & 99.37 & 99.94 & 100.62 & 100. 12 & 100.72 & 100.58 & 100.05 & 100.03 & 100.53 & 100. 19 \\
\hline
\end{tabular}

$a$ Analysis of ignited material.

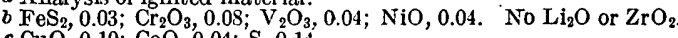

$g \mathrm{~S}, 0.04$. 
ROCKS ANALYZED.

1. Soda trachyte (Cross), nordmarkose, $\mathrm{I}^{\prime} .5 \cdot 1^{\prime} .4$. Launiupoko Hill, a cone near Lahaina, west coast of Maui. Analyst, George Steiger. Specimen in Peabody Museum, Yale University.

2. Soda trachyte obsidian (Cross), nordmarkose-umptekose, (I)II.5.1.4. Puu Waawaa, north base of Mount Hualalai, Hawaii. Analyst, W. F. Hillebrand. Specimen No. 1857, petrographic reference collection, U. S. Geol. Survey.

3. "Feldspathic lava" (Lyons), larvikose-akerose, (I)II.5.2.4. Waimea, Kohala district, Hawaii. Analyst, A. B. luyons, Am. Jour. Sci., 4th ser., vol. 2, p. 424, 1896.

4. 'Trachyandesite (Cross), akerose-essexose, II.(5)6.2.4. White Hill, a cone in the crater of Mount Haleakala,

Maui. Analyst, W. F. Hillebrand. Specimen No. 1860, petrographic reference collection, U. S. Geol. Survey.

5. "Trachydolerite" (Daly), andose, II'.5.3.4. Poliahu cone, near summit of Mauna Kea, Hawaii: Analyst, George Steiger. Specimen No. 1849, petrographic reference collection, U. S. Geol. Survey.

6. Trachyandesite (Cross), akerose, II. $5^{\prime} .2 .4$. Near Vieira ranch, south base of Mount Haleakala, Maui. Analyst, George Steiger. Specimen No. 1859, petrographic reference collection, U. S. Geol. Survey.

7. "Andesitic basalt" (Daly), andose, II.5.3.4. 11,000-foot contour, S. $75^{\circ}$ E. of summit of Mauna Kea, Hawaii. Analyst, George Steiger. Specimen No. 1850, petrographic reference collection, U. S. Geol. Survey.

8. "Tighly feldspathic lava" (Lyons), beerbachose-andose, $\mathrm{II}^{\prime} \cdot 5.3 .4(5)$. Waianae Mountains, Oahu. Analyst,

A. B. Lyons, loc. cit.

9. "Basalto a struttura microgranitica" (Silvestri), salemose-andose, II'.5(6).3.4. Wall of caldera, Kilauea,

Hawaii. Analyst, O. Silvestri, Com. geol. Italia Bull., vol. 19, p. 187, 1888.

1.0. "Porphyritic lava" (Lyons), andose-beerbachose, II(III).5.3'.(4)5. Kohala Mountain, northern district of

Hawaii. Analyst, A. B. Lyons, loc. cit.

11. "Andesite augitica" (Silvestri), limburgose-salemose, II(III).'6.3.(3)4. Wall of caldera of Kilauea, Hawaii.

Analyst, O. Silvestri, op. cit., p. 191.

12. "Basaltoide microgranitica" (Silvestri), camptonose-andose, II(III).5.3.4. Wall of caldera of Kilauea,

Hawaii. Analyst, O. Silvestri, op. cit., p. 173.

1.3. "Orneblendafiro basaltico" (Silvestri), kilauose-akerose, II(III).5.2.4. 'Wall of caldera, Kilauea, Hawaii. Analyst, O. Silvestri, op. cit., p. 178.

14. Basalt stalagmite (Phillips), auvergnose-koghose, (II)III.4(5).4.4-5. In lava cave in caldera of Kilauea.

Collected by Libbey. Analyst, A. H. Phillips, Am. Jour. Sci., 3d ser., vol. 47, p. 473, 1894.

15. "Basaltoide" (Silvestri), monchiquose-kilauose, (II)III.5(6).2'.4. Wall of caldera of Kilauea, Hawaii.

Analyst, O. Silvestri, op. cit., p. 181.

16. "Basaltoide" (Silvestri), andose-camptonose, (II)III.5.3:4'. Wall of caldera of Kilauea, Hawaii. Analyst, O. Silvestri, op. cit., p. 175.

17. "Basaltoide" (Silvestri), auvergnose-camptonose, (II)III.5.3(4).4. Wall of caldera of Kilauea, Hawaii. Analyst, O. Silvestri, op. cit., p. 183.

1. "Pele's hair" (Iyons), ornose-camptonose, 'III.5.3.4(5). Kilauea, Hawaii. Analyst, A. B. Lyons, loc. cit. 19. Basalt (Lyons), ornose, 'III.(4)5.3'.5. Koolau Mountains, Oahu. Analyst, A. B. Lyons, loc. cit.

20. Basalt, "kilaueite" (Silvestri), auvergnose, 'III.'5.4.4-5. Wall of caldera of Kilauea, Hawaii. Analyst, O. Silvestri, op. cit., p. 1.85.

21. Basalt; (Silvestri), auvergnose, III.5.4.4-5. Lava of May, 1883, Kilauea, Hawaii. Analyst, O. Silvestri, op. cit., p. $135 \overline{5}$.

22. Basalt, (J. D. Dana), auvergnose, III.5.4.4-5. Kilauea, Hawaii. Analysts, F. J. and O. D. Allen, Am. Jour. Sci., 3d ser., vol. 1.8, p. 134, 1879.

23. "Basalt obsidian" (Cohen), camptonose-ornose, III.5.3.(4)5. Kilauea, Hawaii. Analyst, E. Cohen, Neues Jahrb., 1.850, vol. 2, p. 41.

24. "Pele's hair" (Phillips), ornose-auvergnose, IIT.5.(3)4.4-5. Kilauea, Hawaii. Analyst, A. H. Phillips, loc. cit. 25. "Lava doleritica" (Silvestri), camptonose, III.5.3.4. Recent lava, Halemaumau, Kilauea, Hawaii. Anälyst,

O. Silvestri, op. cil., p. 141 .

26. Kauaiite or oligoclase gabbro (Cross), kilauose, III.5'.2.4'. East branch of Waimea Canyon, Kauai. Analyst,

W. T. Schaller. Specimen No. 1861, petrographic reference collection, U. S. Geol. Survey.

27. "Basalt obsidian" (Cohen), ornose-camptonose, III.5.3'.4(5). Lava of 1843, Kilauea, Hawaii. Analyst, E. Cohen, 7oc. cit.

28. "Traplike basalt" (Lyons), ornose, III.(4)5.3.5. Waianae Mountains, Oahu. Analyst, A. B. Lyons, loc. cit. 29. Pahoehoe basalt, auvergnose, III.5.4.4-5. Floor of Kilauea, flow of 1894 (?). Collector, A. L. Day. Analyst,

J. B. Ferguson, Carnegie Geophysical Laboratory.

30. Basalt (hyaline), ornose-camptonose, III.5.3(4).4(5). Fluid lava, dipped from basin in Halemaumau, Kilauea.

Collected by Perret and Shepherd, 1911. Analyst, J. B. Ferguson, Carnegie Geophysical Laboratory.

31. Plagioclase-olivine basalt (Cross), auvergnose, III.5.4.4-5. Flow, border of Olokele Canyon, Kauai. Analyst,

W. T. Schaller. Specimen No. 1863, petrographic reference collection, U. S. Geol. Survey.

32. Basalt pumice (Cohen), camptonose-ornose, III'.5.(2)3.(4)5. Flow from Mauna Loa, 1868, Hawaii. Analyst, E. Cohen, loc. cit.

33. Plagioclase-olivine basalt (Cross), auvergnose, $\mathrm{III}^{\prime}$.5.4.4-5. Fragment in old tuff, Kilauea, Hawaii. Analyst, George Steiger. Specimen No. 1862, petrographic reference collection, U. S. Geol. Survey.

$48730^{\circ}-15 \longrightarrow 4$ 
34. "Pele's hair" (Cohen), kilauose, III'.5.2'.4'. Kilauea, Hawaii. Analyst, E. Cohen, loc. cit.

35. Plagioclase-olivine basalt (Cross), camptonose-auvergnose, III'.5'.(3)4.4-5. Flow, border of Olokele Canyon, Kauai. Analyst, W. F. Hillebrand. Specimen No. 1864, petrographic reference collection, U. S. Geol. Survey.

36. "Basaltic scoria" (Lyons), monchiquose, III(IV).6'.2(3).(4).5. Cinder cone, Punahou, near Honolulu, Oahu. Analyst, A. B. Lyons, loc. cit.

37. "Black sand" (Lyons), casselose. (III)IV.2./4.2(3).2'. Recent lapilli, Punahou, near Honolulu, Oahu. Analyst, A. B. Lyons, loc. cit.

38. "Ultrafemic olivine basalt" (Daly), palisadose-hilose, (III)IV.1(2).2'1(2).2. Flow of 1852, Mauna Loa, Hawaii. Analyst, George Steiger. Specimen No. 1848, petrographic reference collection, U. S. Geol. Survey.

39. Picritic basalt (Cross), rossweinose-uvaldose, 'IV.(1)2./3.2.2. Summit of Mount Haleakala, Maui. Analyst, George Steiger. Specimen No. 1866, petrographic reference collection, U. S. Geol. Survey.

40. Nephelite-melilite basalt (Cross), uvaldose-casselose, 'IV:2.(3)4.2(3).2(3). Moiliili, rear Honolulu, Oahu. Analyst, George Steiger. Specimen No. 1868, petrographic reference ecollction, U. S. Geol. Survey.

41. Picritic basalt (Cross), rossweinose-wehrlose, 'IV.1'/3.1(2).2. Flow of 1840, Nanawale, Puna. Hawaii. Analyst, George Steiger. Specimen No. 1865, petrographic reference collection, U. S. Geol. Survey.

42. "Porphyritic gabbro" (Daly), rossweinose-wehrlose, IV.1(2).3.1(2).2. Uwekahuna laccolith, Kilauea, Hawaii. Analyst, George Steiger. Specimen No. 1847, petrographic reference collection, U. S. Geol. Survey.

43. Nephelite-melilite basalt (Cross), uvaldose, IV.2.3.2.2. Kilauea Bay landing, north coast of Kauai. Analyst, W. F. Hillebrand. Specimen No. 1867, petrographic reference collection, U. S. Geol. Survey.

Silica and alumina.-A review of the analyses of the foregoing table shows a great range for every constituent. Silica is, relatively to its total amount, the least variable of all components, in 35 out of 43 analyses falling between 45 and 54 per cent. In 25 rocks it varies less than 2 per cent from 50 per cent. Of the extreme rocks, four are notably basic, and but three are even moderately high in silica.

Alumina ranges from 18.87 per cent in No. 9 to 7.69 per cent in No. 42 . The variations in alumina are quite independent of those of silica and of individual bases. This finds correct expression in the norms by the great variation in orthoclase, albite, and anorthite in rocks of similar silica contents.

Iron oxides.-Some of the determinations of the iron oxides may be more or less incorrect as to the relative amounts of $\mathrm{Fe}_{2} \mathrm{O}_{3}$ and $\mathrm{FeO}$. The totals of the two oxides range from 4.29 per cent in the trachyte of No. 2 to 20.86 per cent in the "basaltoid" of No. 16. The latter rock was analyzed by Silvestri, and it is notable that in most of his analyses the total of iron oxides is higher than in those of similar rocks by other analysts. In 13 of the analyses made in the laboratory of the Geological Survey the range for the combined iron oxides is only from 10.03 to 14.40 , the average being 11.93. By excluding five extreme rocks it is found that all the analyses except those of Silvestri report the iron oxides as ranging only from 9.98 to 14.40 per cent. This agreement appears to raise some question as to the accuracy of Silvestri's figures for the iron oxides, which average 15.75 per cent for 10 rocks. On the whole there is a rather remarkable constancy in the iron contents of many kinds of Hawaiian lavas.

Magnesia and lime.-Magnesia varies most notably in these rocks. Exclusive of the trachytes, Nos. 1 and 2, it ranges from 1.59 (No. 3) to 21.79 (No. 42). In 12 analyses of rocks, most of which have been called basalt by the petrographers describing them, the magnesia content falls below 4 per cent; in 9 analyses it exceeds 10 per cent. This great variation in magnesia is quite independent of the development of olivine, as will be shown in another place.

Lime is also a variable constituent, ranging from 0.86 per cent (No. 2) to 13.85 per cent (No. 43). In only 7 analyses is it reported below 7 per cent, and in 22 it exceeds 9 per cent.

Alkalies.-The alkalies taken together are very abundant in many of the Hawaiian rocks. In 16 analyses more than 5 per cent is given. The trachyte is naturally the most richly alkalic rock, but several other types, including some of the most mafic, are also rich in alkalies.

The most notable chemical characteristic of these rocks is the predominance of soda over potash. In only one rock, the "andesite augitica" from Kilauea, analyzed by Silvestri, is the reported potash molecularly equal to one-half the soda. In most of the rocks the potash is less than one-third of the soda. These molecular relations are given in the table of normative ratios, except for a few rocks in which there is some femic soda. 
Minor constituents.-Of the minor chemical constituents titanic acid must be considered as highly characteristic of these lavas. In 14 analyses from the laboratory of the Geological Survey, not considering those of trachytes (Nos. 1 and 2), the range for $\mathrm{TiO}_{2}$ is from 1.48 (No. 38) to 4.05 (No. 36), with an average of 2.44 per cent. In eight analyses by Lyons the range is from 1.88 (No. 3) to 5.35 (No. 8), with an average of 3.47 per cent. In the 22 rocks analyzed by Lyons and the Survey chemists the average for $\mathrm{TiO}_{2}$ is 2.81 per cent. From these data it seems probable that Silvestri's determinations of $\mathrm{TiO}_{2}$ are too low, in most cases at least. He reports a trace of $\mathrm{TiO}_{2}$ in three rocks, a maximum of 1.81 per cent and an average for 10 rocks of but $0.73 \mathrm{per}$ cent. His rocks were all from Kilauea, but all other modern analyses of rocks from that center show high contents in $\mathrm{TiO}_{2}$. Phosphoric acid is probably present in all Hawaiian lavas, though seldom reported in.noteworthy amounts. It is most abundant in the alkalic gabbro, kauaiite (No. 26), there reaching 2.20 per cent. The water content of Hawaiian rocks is decidedly low. Lyons's analyses were all made on ignited material and thus show no water. Only the analyses from the Geophysical Laboratory and the Geological Survey distinguish between water expelled above and below $110^{\circ} \mathrm{C}$. In these 17 analyses the water above $110^{\circ}$ C. is less than 1 per cent in all but the three basic rocks, Nos. 39, 40, and 43 . Water expelled below $110^{\circ} \mathrm{C}$. is usually of very small amount. Baryta and strontia were found in determinable amounts in most of the rocks analyzed in the Survey laboratory. Manganese is present in considerable amount in these lavas. It is notable that Silvestri reports more than 1 per cent in scveral rocks, while Lyons gives a corresponding amount only in the black ash of Honolulu (No. 37) and 0.32 per cent is the maximum found by the chemists of the Geological Survey in 15 analyses. Among the rarer substances $\mathrm{ZrO}_{2}, \mathrm{Cr}_{2} \mathrm{O}_{3}, \mathrm{~V}_{2} \mathrm{O}_{3}, \mathrm{~S}$, and $\mathrm{NiO}$ have been determined, each in several rocks. Lyons reports $\mathrm{CuO}$ in most of his analyses, but no other analyst has found it, and it seems possible that the copper detected by Lyons came from utensils used in his analysis. (A recent determination, by George Steiger, of the CuO in a composite sample representing 71. specimens from Hawaii yielded 0.016 and 0.015 per cent in two tests by different methods.)

It is notable that the two recent analyses of lavas from Kilauea, made by Ferguson in the Geophysical Laboratory, show $\mathrm{Cl}$ and $\mathrm{MoO}_{3}$. While investigating the occurrence of molybdic acid in igneous rocks Ferguson found a trace of it in the trachyte obsidian of Puu Waawaa, using the same material which had been analyzed earlier by Hillebrand (No. 2 of table, p. 47).

\section{NORMATIVE COMPOSITION.}

The table of norms.-For the interpretation of the variations exhibited in any group of rock analyses $I$ find it a great help to translate the analyses into norms. The accompanying table gives the norms calculated from the analyses, presented in the same order:

Norms of Hawaiian lavas.

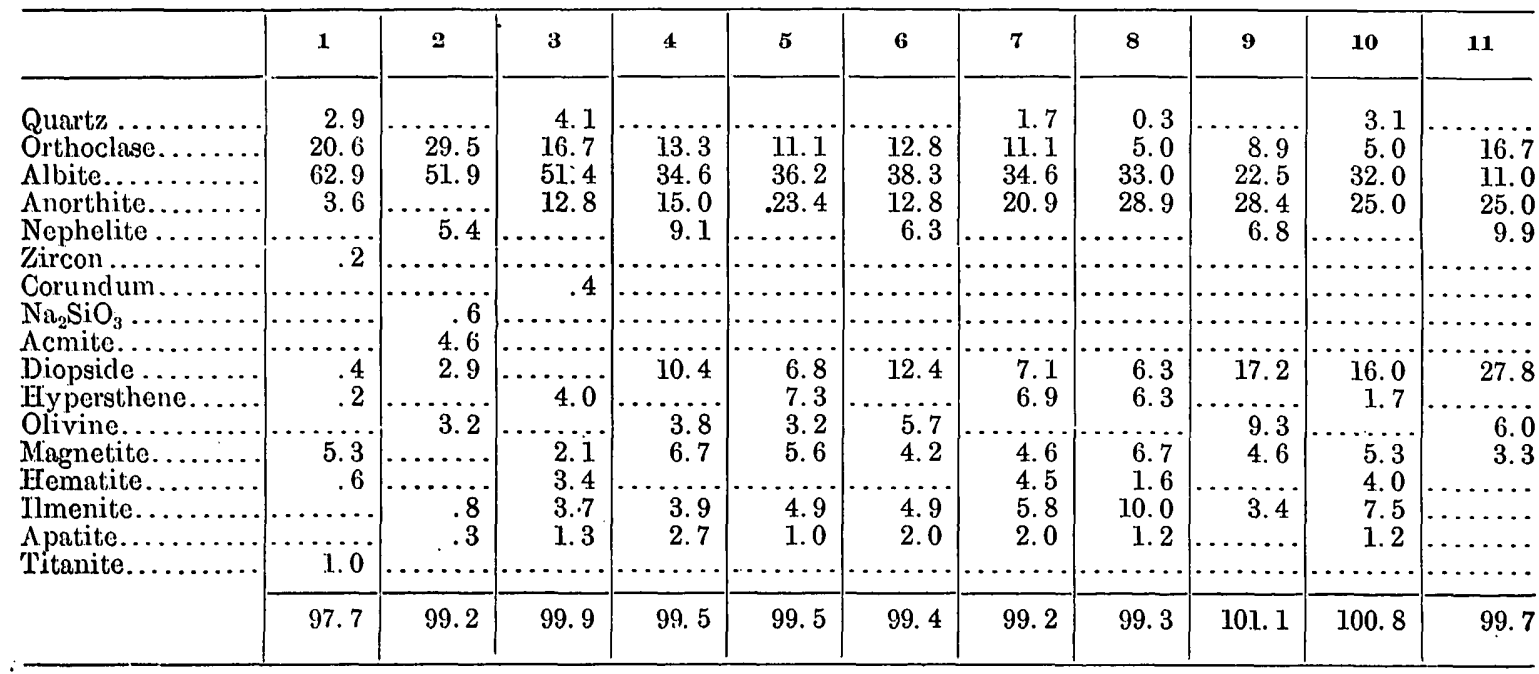


Norms of Hawaiian lavas-Continued.

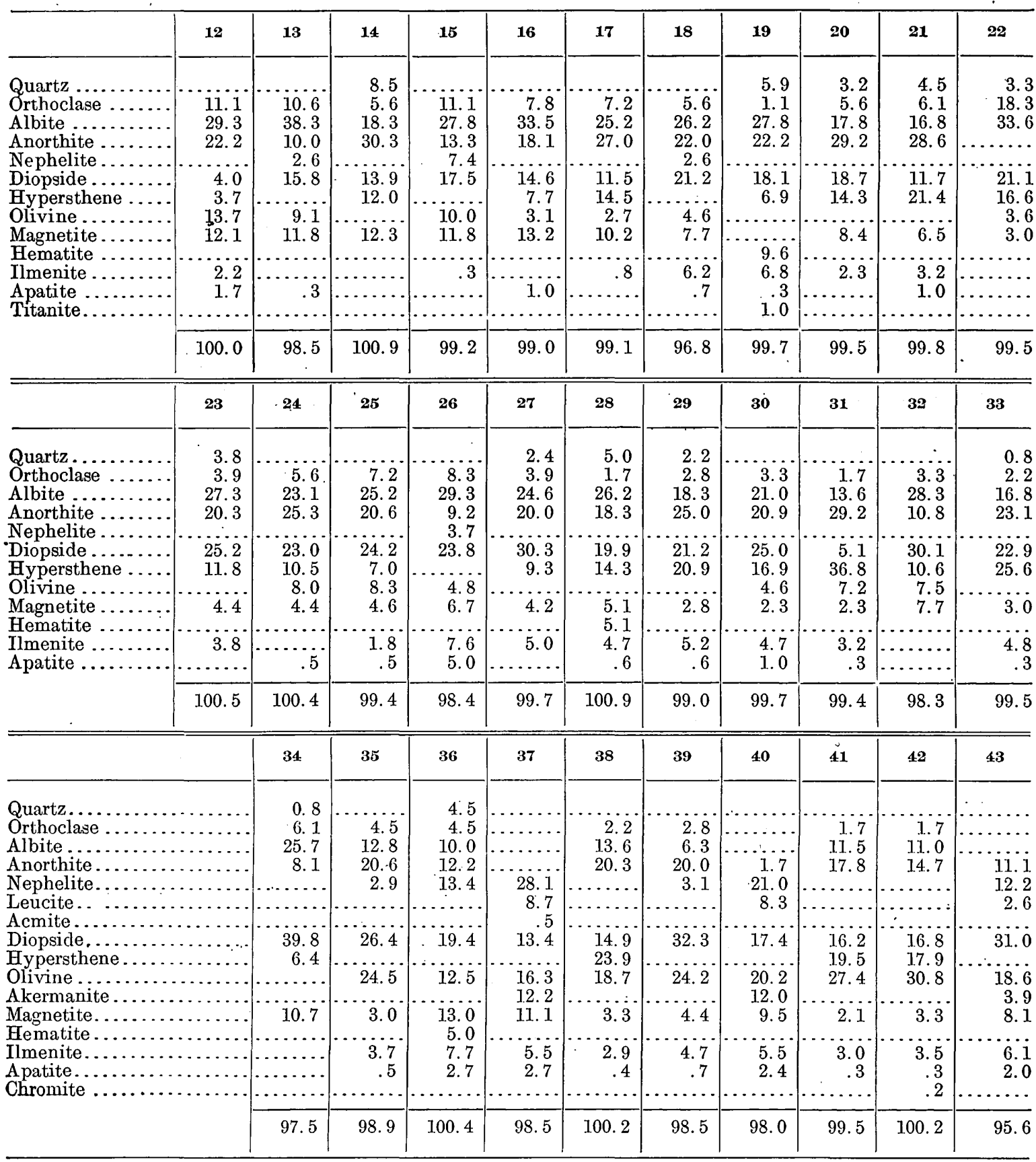

No'TE.-The norms of analyses published in Washington's Tables have been recalculated in order to show apatite and use $\mathrm{MnO}, \mathrm{BaO}, \mathrm{SrO}$, etc., which were sometimes disregarded in the original calculations.

Object of normative study.-For the benefit of petrographers who have not utilized the norm as a means of studying rock analyses, it may not be superfluous to point out again that the analysis of an igneous rock represents as completely as is now possible the composition of $\dot{a}$ former magmatic solution which under certain physical conditions has solidified into that rockhyaline, hypohyaline, or crystalline. A magmatic solution is a most complex system which, as crystallization progresses, naturally suffers many changes corresponding to those of attendant conditions, especially of temperature. Now, it is well known that many magmas may resolve into more or less markedly different mineral combinations or modes under the influence of 
varying and little-understood conditions. Yet the general laws of chemical affinity control the result of crystallization to a high degree, and the norm is a set of standard mineral molecules, chosen with regard to the laws of chemical affinity, into which all rock analyses may be translated for purposes both of comparison and of classification. In fact, the normative molecules are chiefly those which many petrographers regard as present in the magmatic solution shortly prior to consolidation, if not at that time. Moreover, the normative molecules correspond to those of the mode to a much greater extent than many petrographers realize.

Salic molecules.-On taking the elements of the norm in order, it appears at once a striking feature of these basaltic rocks that 13 of them contain normative quartz, and that the rocks so characterized are not as a group the ones richest in $\mathrm{SiO}_{2}$ or salic molecules. This feature is discussed in another place.

Orthoclase occupies the subordinate place determined by potash. Albite is notably prominent, as a rule. By taking nephelite and albite together the strong sodic character of the group is made very clear.

Nephelite appears in 15 norms, indicating insufficient silica for the formation of albite, but the abnormative mode as regards this constituent is one of the interesting points to be discussed elsewhere.

Leucite appears in but three norms, and these of very basic rocks.

Femic molecules.-Diopside, which depends on the excess of lime after anorthite and apatite, is found in all but one norm-No. 3. The rock is one analyzed by Lyons and is briefly described as rich in feldspar and poor in olivine.

Hypersthene occurs in all norms except those with nephelite and varies greatly in importance, being at a maximum of 36.8 per cent in No.31. It is usually rich in magnesia, and in some norms has no iron. This may be due to analytical errors as regards the determination of iron oxides.

Olivine is highly variable, and is in many norms less than in the mode of the rocks analyzed, a discrepancy to be commented on in discussing relations of norm and mode.

The total of iron-bearing oxides is small in many norms, and yet it is higher than it should be in all those where $\mathrm{Fe}_{2} \mathrm{O}_{3}$ has been erroneously determined in excess, as may be assumed to be the fact in some of the analyses. The ilmenite, which runs unusually high, corresponds with the abundance of $\mathrm{TiO}_{2}$ in the analyses.

Apatite is variable, rising to 5 per cent in the alkalic gabbro of Kauai and appearing to the amount of about 2 per cent in some of the more alkalic rocks. It is very low in most of the notably basic lavas, but becomes prominent in the recent and relatively alkalic nephelite-melilite basalt and similar rocks near Honolulu

Diagram of norms.--The norms are graphically expressed in a new form of diagram (Pl. IV), which also shows the distribution of the rocks in Classes II, III, and IV of the quantitative system. This diagram is simply a rectangle the diagonal of which expresses the possible variation of salic (Sal) and femic (Fem) components from 0 to 100 per cent. The scale and form of the rectangle may, of course, be suited to the needs of special cases. The norms being recalculated to 100 per cent, where necessary, the position of a given rock in this diagram is shown by the percentage of Sal or Fem. From the point on the base of the rectangle thus determined an ordinate may be drawn which will be divided by the diagonal into parts corresponding to the amounts of Sal and Fem. The elements of Sal and Fem may then be laid off additively on this ordinate. The norm may be represented by all the molecules stated or by groups of these, or the chemico-mineral character may be expressed in greater detail by using the constituent parts of compound molecules, such as diopside, hypersthene, and olivine.

In the accompanying diagram the salic molecules are shown as in the norms, but the femic silicates have been split into lime, iron, and magnesia metasilicates and orthosilicates. The sum of the metasilicates equals diopside and hypersthene; that of the orthosilicates equals olivine. The arrangement of the diagram is such as to show readily the total of lime and magnesia silicates, through placing anorthite and wollastonite together, and enstatite and forsterite. The iron 
metasilicate is placed between those of lime and magnesia; but fayalite comes next to magnetite, which is followed by hematite and ilmenite, so that all the iron-bearing molecules come together except the metasilicate. By placing akermanite next to anorthite, when it occurs, all limebearing molecules come together except the subordinate apatite.

By this diagram the normative mineral character of the whole series of analyses, which is useful as an interpretation of the chemical statement, is brought out in a striking manner.

It may be well to call attention to the fact that the quartzose orders 4,3 , etc., may be readily distinguished on this diagram from the perfelic order 5 , when the salic part of the norm is free from corundum. If the normative quartz is plotted next to the upper boundary of the diagram, lines may be drawn through the sections of Classes I, II, and III, representing 12.50 and 37.50 per cent of normative quartz. These lines represent the limits of the quardofelic order 4, as against the perfelic order 5 on the one side and the quarfelic order 3 on the other. Orders 2 and 1 can obviously also be expressed by the lines representing 62.50 and 87.50 per cent of normative quartz in the salic division.

\section{RELATION OF' NORM AND MODE.}

The Hawaiian rocks range from those in which feldspars greatly predominate, and for which norm and mode must be in practical agreement, to those which are rich in augite and olivine, and for which several conditions lead to marked divergence between norm and mode. This divergence is due partly to the abnormative character of the alferric augite, partly to the entrance of $\mathrm{FeO}$ and $\mathrm{TiO}_{2}$ into the augite, instead of forming the full amount of normative magnetite and ilmenite, and partly to a greater development of olivine than is necessary considering the amount of silica present. Other minor causes of variation are to be recognized.

Quartz.-The appearance of quartz in the norms of 13 rocks raises at once the query whether the silica determinations. in the analyses concerned are correct. But there seems to be no good reason for casting suspicion on these figures, for the normative quartz is not especially. prominent in those rocks that have the highest silica contents. Eight of the 13 rocks are from Kilauea, and were analyzed by Cohen (3), Silvestri (2), Phillips (1), Steiger (1), and Ferguson (1). These rocks of Kilauea embrace the kilaueite of Silvestri, from the outer caldera wall, one fragment in tuff, and several modern flows from Halemaumau, including those of 1843,1883 , and 1894. The five rocks analyzed by Lyons which show normative quartz include bronzite basalts of Oahu and highly feldspathic lavas of the Kohala Mountains.

If the normative quartz is due to analytical errors, the mistake is more likely to lie in an excessive amount of ferric oxide. Such an error results in the appropriation of an undue amount of $\mathrm{FeO}$ for magnetite. The analyses of Lyons are especially subject to this suspicion.

By the normative calculation $\mathrm{FeO}$ is assigned to $\mathrm{Fe}_{2} \mathrm{O}_{3}$ and $\mathrm{TiO}_{2}$ in the ratio $1: 1$ before any $\mathrm{FeO}$ is allotted to a femic silicate. No doubt the silicates are richer in $\mathrm{FeO}$ than appears in the norm, but it is to be remembered that $\mathrm{TiO}_{2}$ also enters into the silicates with the $\mathrm{FeO}$, and hence the amount of $\mathrm{SiO}_{2}$ needed for the augite is perhaps no greater than that allotted in the normative calculation.

As an offset to the possible decrease of free silica comes the increase where olivine is developed in the rock in excess of the normative figure. As has been shown in the case of the basalt of Olokele Canyon, Kauai, this may result in the presence of abnormative, modal free silica. It is believed that this excessive development of olivine is common among Hawaiian rocks and that in consequence free silica in some form must be present in many of them, even where it would not appear in the norm.

No modal quartz or tridymite has been reported from the rocks whose analyses show normative quartz, but several of them were partly hyaline. The obscure development of tridymite and cristobalite in the chrysophyre of Kauai gives a warning that free silica may readily be overlooked where the assumption of its occurrence might be considered as painfully heterodox.

Feldspars and lenads.-As to the feldspars, the norms must represent nearly the modal composition, except for isomorphous mixture. Micas being absent and hornblende being 


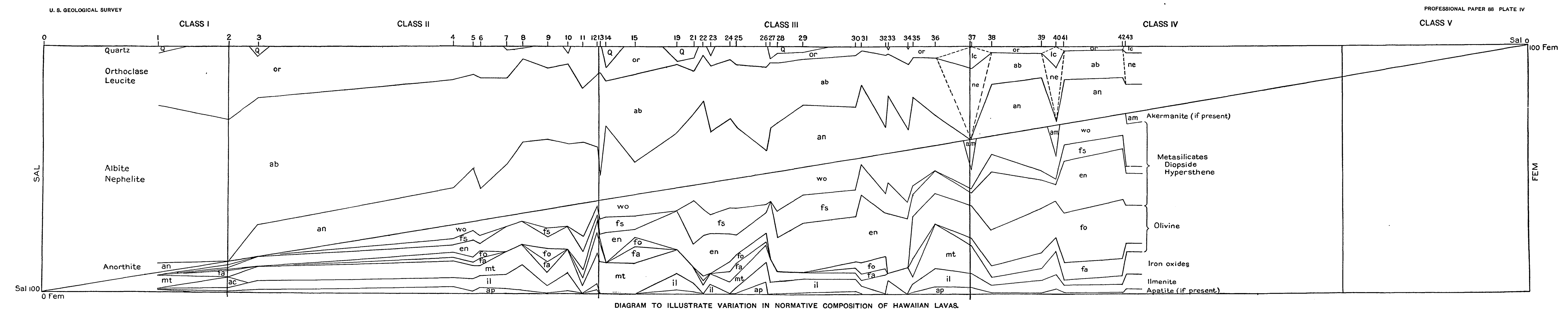


known only in two rocks described by Silvestri, augite is the only alferric silicate whose presence can materially interfere with the development of the feldspars in the normative proportions. Analyses of augite from Hawaiian lavas are not at hand, but in many of them this mineral has the characters of varietties presumably not rich in alumina and the alkalies.

Orthoclase doubtless occurs in part in solid solution in the plagioclase and in part in minute unrecognized interstitial particles or in the vitrophyric base of many rocks.

Leucite has not been observed, but is certainly a potential constituent of a few lavas and must appear where such rocks are holocrystalline.

Nephelite, which appears in 15 norms, is probably present in the mode of but few rocks, aside from the nephelite and melilite basalts of the basic end of the series. Its absence from rocks like many of those analyzed may be directly accounted for in two ways. In the first place, an abnormative development of olivine in any rock with normative nephelite must free silica which would very probably be utilized in turning a certain amount of normative nephelite into albite. In the second place, it appears probable that the normative nephelite may be concealed as carnegieite in solid solution in plagioclase. The possibility of such occult molecules, to use Iddings's expressive term, is certainly to be taken into account in studying the relations of norm and mode. The norm may prove to be an important aid in the detection of such occult constituents.

Nephelite was observed in the flow from Haleakala as represented by the specimen from Vieira's ranch (No. 6), but in less amount than appears in the norm of this rock.

Pyroxenes.-The acmite or ægirite molecule appears in the norm of but one rock, namely, the trachytic obsidian of Puu Waawa (No. 2), a rock which would no doubt exhibit some alkalic and ferric pyroxene or amphibole were it to be found in fresh, holocrystalline state. The ægirite molecule is visible in part of the augite of the granular kauaiite (No. 26) and appears also in the soda trachyte of Maui (No. 1).

The combined normative diopside and hypersthene of these rocks must represent approximately the modal augite with some aluminous and alkalic molecules added thereto. Titanium also doubtless enters into the augite, but seldom betrays itself by a pinkish color, as in the kauaiite.

Olivine.-The abnormative development of olivine in many Hawaiian lavas has been referred to in several places, especially with reference to its effect upon the occurrence of quartz, or some other form of free silica, and of nephelite. It appears to be a notable feature of the Hawaiian lavas that olivine occurs in greater abundance than it would if the available silica of the magma had been utilized to produce compounds of the highest possible silicitythe assumption at the base of the normative calculation. Such excess of olivine must be accompanied by a decrease in the metasilicate expressed in the norm as hypersthene.

Akermanite and melitite.-Akermanite appears in three norms (Nos. 37, 40, 43) and corresponds to the development of melilite, though not an accurate expression of its abundance. The akermanite molecule is here, as in many other rocks, a serviceable though not entirely satisfactory representative in the norm of the complex modal melilite.

CLASSIFICATION.

QUALITATIVE SYSTEM.

An appropriate classification and naming of Hawaiian lavas by the current mineralogical or qualitative system is a task of great difficulty. They belong mainly to the general family of basalts, but even here arises the question, vital to adherents of the Rosenbusch system, whether they are true basalts or trachydolerites. Apparently it is inadmissible to say that both occur together, and I must leave this problem for those who believe in a distinction of alkalic and calcic members of the great basaltic group, with reference to data bearing on this point presented in later sections of this discussion.

In these lavas each of the essential elements of basalt, plagioclase, augite, and olivine varies in amount from dominance almost or quite to disappearance. The character of plagioclase 
varies from calcic labradorite to andesine or oligoclase. Considering the rarity or absence of olivine in some of the lavas, Cohen, E. S. Dana, Lyons, and Silvestri have called certain rocks andesite or pointed out the gradation to andesite. If the character of the plagioclase is taken in account in deciding whether rocks poor in olivine are basalts or andesites, one encounters the difficulty that the more distinct feldspars are apt to be labradorite where chemical analysis shows that much sodic feldspar and some orthoclase must be in the obscure or hyaline matrix.

Of the 43 rocks analyzed, 16 have normative labradorite and the same number andesine. Although the tendency appears to be marked to introduce greater precision into current system by recognition of quantitative factors, this tendency has not gone far enough to meet the requirements of the variations exhibited by the Hawaiian lavas of the basaltic group.

In Part II of Iddings's work on igneous rocks he proposes certain names intended to give greater precision to mineralogical classification. Among these are several terms derived from Hawaii. Thus hawaiite ${ }^{1}$ is proposed for salfemic andesine basalts. This refers to normative andesine and implies an estimate, at least, of chemical composition. By this definition Nos. 15, $16,18,19,23,25,27,28,30$, and 32 belong to hawaiite, when they also carry olivine. Several of them, however, are hyaline, and one must refer to their chemical composition for this classification.

As has been stated elsewhere in this paper, Iddings has further proposed the names kohalaite ${ }^{2}$ for a dosalic oligoclase andesite and kauaiite ${ }^{3}$ for an oligoclase-augite diorite, referring in these cases also to the average or normative plagioclase.

The more felsic and more mafic lavas of Hawaii are more readily named than the feldspar basalt group, and their classification need not be specially discussed here, except to refer to the uncertainty as to whether such rocks as the dosalanes of Haleakala (Nos. 4 and 6) and Mauna Kea (Nos. 5 and 7) are, under the circumstances, alkalic or calc-alkalic, in the Rosenbusch sense. For instance, a disciple of Rosenbusch could not accept both of Daly's names (andesitic basalt and trachydolerite) for the allied lavas of Mauna Kea.

\section{QUANTITATIVE` SYSTEM.}

The detailed quantitative classification of all rocks analyzed is shown in the accompanying table of normative ratios and symbols. This has been carried out with a fivefold subdivision of certain subrangs and subgrads where the threefold subdivision would have been sufficient for the purpose of applying the quantitative names. The purpose of this detail is to bring out more uniformly and clearly in the symbols certain characteristic chemical features of these rocks. For the same reason the divisions of Class IV have been transposed in the table to bring the ratios and symbols for each normative datum in one column. 'The expression of transitional and intermediate relations in the symbols by the use of parentheses and accent marks, respectively, accords with the recent proposal of the authors of the quantitative system. ${ }^{4}$ The quantitative names, with numbers corresponding to those in the table, are given below.

Quantitative system names.

1. Nordmarkose.

2. Nordmarkose-umptekose.

3. Larvikose-akerose.

4. Akerose-essexose.

5. Andose.

6. Akerose.

7. Andose.

8. Beerbachose-andose.

9. Salemose-andose.

10. Beerbachose-andose.

11. Limburgose-salemose.

12. Camptonose-andose.

13. Kilauose-akerose.

14. Auvergnose-koghose.

15. Monchiquose-kilauose.

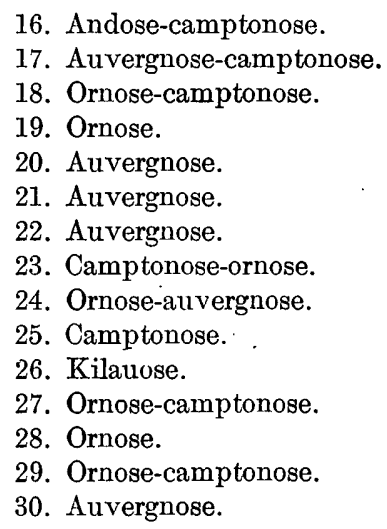

1 Igneous rocks, pt. 2, p. 198, New York, 1913.
31. Auvergnose.

32. Camptonose-ornose.

33. Auvergnose.

34. Kilauose.

35. Camptonose-auvergnose.

36. Monchiquose-(unnamed).

37. Casselose.

38. Palisadose-hilose.

39. Rossweinose-uvaldose.

40. Uvaldose-casselose.

41. Rossweinose-wehrlose.

42. Rossweinose-wehrlose.

43. Uvaldose. 
Normative ratios and symbols.

Clasoes I and II.-Persalanes and dosalanes.

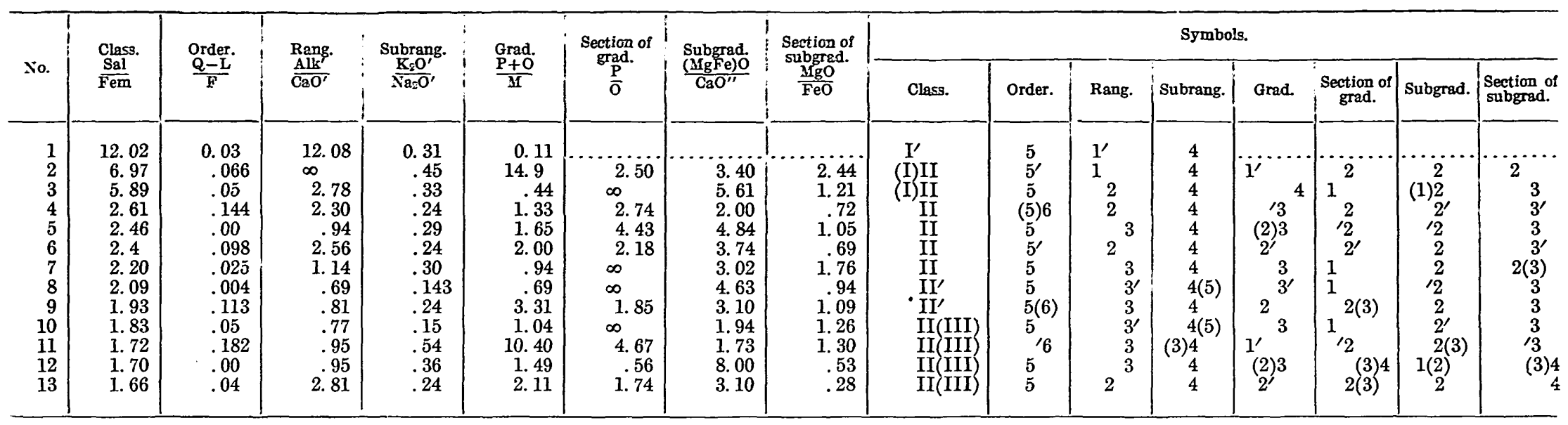

Class III.-Salfemanes.

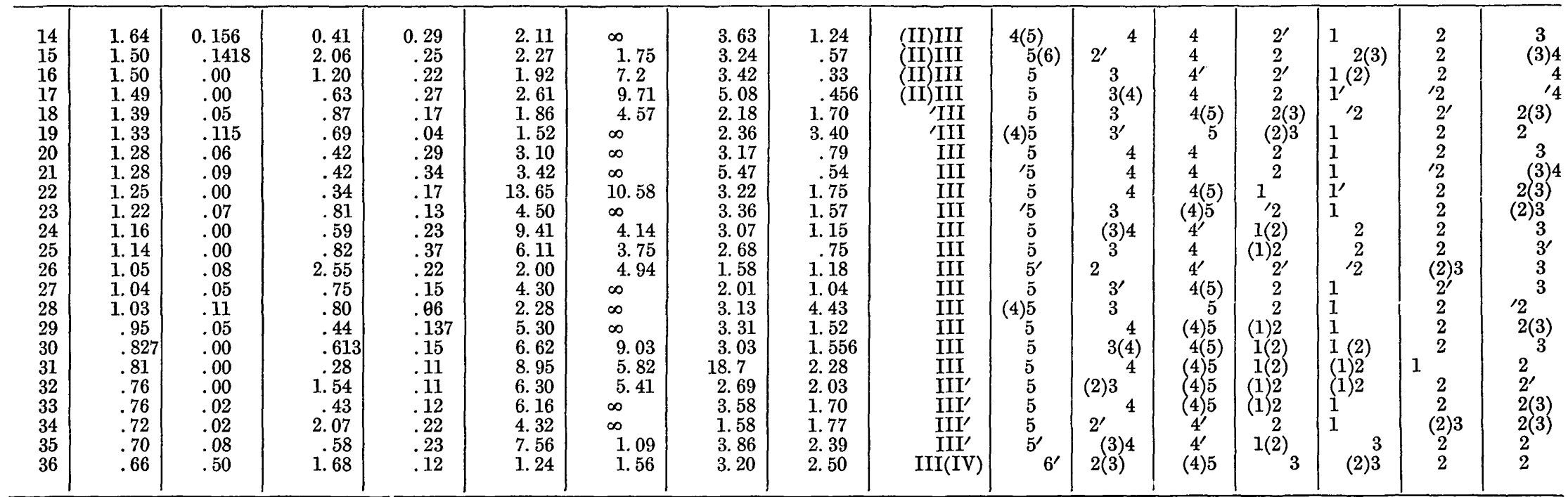

Class IV.-Dofemanes.

\begin{tabular}{|c|c|c|c|c|c|c|c|c|c|c|c|c|c|c|c|c|}
\hline \multirow[b]{2}{*}{ No. } & \multirow{2}{*}{$\begin{array}{l}\text { Class. } \\
\frac{\text { Fal }}{\mathrm{Fem}}\end{array}$} & \multirow{2}{*}{$\begin{array}{c}\text { Grad. } \\
\stackrel{L}{\bar{F}}\end{array}$} & \multirow{2}{*}{$\begin{array}{l}\text { Subgrad. } \\
\frac{\mathrm{Alk}}{\mathrm{CaO^{ \prime }}}\end{array}$} & \multirow{2}{*}{$\begin{array}{l}\text { Section of } \\
\text { subgrad. } \\
\underline{\mathrm{K}_{2} \mathrm{O}^{\prime}} \\
\sqrt[\mathrm{Na}_{2} \mathrm{O}^{\prime}]{ }\end{array}$} & \multirow{2}{*}{$\begin{array}{l}\begin{array}{l}\text { Order. } \\
P+O\end{array} \\
\mathbf{M}\end{array}$} & \multirow{2}{*}{$\begin{array}{l}\text { Section of } \\
\text { order. } \\
\stackrel{P}{\bar{O}}\end{array}$} & \multirow{2}{*}{$\begin{array}{c}\text { Rang. } \\
\frac{(\mathrm{MgFe}) \mathrm{O}}{\mathrm{CaO}^{\prime \prime}}\end{array}$} & \multirow{2}{*}{$\begin{array}{c}\text { Subrang. } \\
\frac{\mathrm{MgO}}{\mathrm{FeO}}\end{array}$} & \multicolumn{8}{|c|}{ Symbols. } \\
\hline & & & & & & & & & Class. & Grad. & Subgrad. & $\begin{array}{l}\text { Section of } \\
\text { subgrad. }\end{array}$ & Order. & $\begin{array}{l}\text { Section of } \\
\text { order. }\end{array}$ & Rang. & Subrang. \\
\hline $\begin{array}{l}37 \\
38 \\
39 \\
40 \\
41 \\
42 \\
43\end{array}$ & $\begin{array}{l}0.596 \\
.563 \\
.49 \\
.46 \\
.452 \\
.38 \\
.37\end{array}$ & $\begin{array}{c}\infty \\
0.0 \\
.11 \\
17.5 \\
.0 \\
.0 \\
1.33\end{array}$ & $\begin{array}{c}\infty \\
0.41 \\
.39 \\
15.5 \\
.39 \\
.45 \\
1.23\end{array}$ & $\begin{array}{l}0.20 \\
.15 \\
.22 \\
.26 \\
.14- \\
.14+ \\
.14-\end{array}$ & $\begin{array}{r}2.55 \\
9.37 \\
6.20 \\
3.10 \\
12.28 \\
9.36 \\
3.77\end{array}$ & $\begin{array}{l}0.49 \\
2.08 \\
1.33 \\
.54 \\
1.30 \\
1.11 \\
1.38\end{array}$ & $\begin{array}{l}1.69 \\
8.53 \\
3.36 \\
1.86 \\
8.49 \\
8.77 \\
2.31\end{array}$ & $\begin{array}{l}2.01 \\
3.57 \\
2.50 \\
1.77 \\
3.42 \\
3.70 \\
2.77\end{array}$ & $\begin{array}{r}\text { (III)IV } \\
\text { (III)IV } \\
\text { 'IV } \\
\text { 'IV } \\
\text { 'IV } \\
\text { IV } \\
\text { IV }\end{array}$ & $\begin{array}{ll} & 9 \\
5 & \\
5(6) & \\
5 & 9 \\
5 & \\
& 7\end{array}$ & 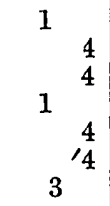 & $\begin{array}{l}4^{\prime} \\
4(5) \\
4^{\prime} \\
4 \\
(4) 5 \\
4(5) \\
(4) 5\end{array}$ & $\begin{array}{c}2 \\
1(2) \\
(1) 2 \\
2 \\
1^{\prime} \\
1(2) \\
2\end{array}$ & $\begin{array}{c}2^{\prime} \\
{ }^{\prime} 3 \\
(3) 4 \\
3 \\
3 \\
3 \\
3\end{array}$ & $\begin{array}{c}2(3) \\
1(2) \\
2 \\
2(3) \\
1(2) \\
1(2) \\
2\end{array}$ & $\begin{array}{l}2^{\prime} \\
2 \\
2 \\
2(3) \\
2 \\
2 \\
2\end{array}$ \\
\hline
\end{tabular}


General result of the classification.-All but the three most salic rocks come within the range of two classes; that is, in Class III or the adjacent halves of Classes II and IV.

As to the relation of feldspar to quartz or lenads, determining orders in Classes II and III and grads in Class IV, one is quardofelic and 36 are perfelic. Of the latter, two are transitional to the quardofelic and three to the lendofelic order. Three are lendofelic, one of them transitional to perfelic, and three of the basic rocks are still richer in lenads. It is interesting to note that the rocks richest in noimative quartz are mostly near the center of Class III.

The strong position of alkali feldspar and lenads as compared with anorthite is brought out strikingly in the symbols. But 11 rocks are docalcic and none percalcic, while four are peralkalic.

The dominance of sodic over potassic silicates is most strongly emphasized in the symbols, which indicate that 32 rocks are dosodic, only one of them being transitional to the sodipotassic subrang, while seven are transitional to the persodic divisions and 11 are persodic. This is the most persistent characteristic brought out by the normative analysis.

The ratio $\frac{P+O}{M}$ is one of the most irregular and is very directly affected by analytical errors, if such there are, in the determination of $\mathrm{Fe}_{2} \mathrm{O}_{3}$ and $\mathrm{FeO}$. High $\mathrm{Fe}_{2} \mathrm{O}_{3}$ increases the magnetite or hematite, and thus has marked effect on this ratio. The great majority of the norms are dopolic, and most of the polmitic ones belong in Class II.

, The low amount of normative olivine causes a great many rocks to fall in the perpyric division, while another large group is dopyric, and the pyrolic rocks are almost restricted to Class IV. Only three rocks are domolic.

The ratio for $\frac{(\mathrm{MgFe}) \mathrm{O}}{\mathrm{CaO}^{\prime \prime}}$ is one of the least variable, 35 out of 42 rocks in Classes II, III, and IV yielding domiric norms, while five are permiric and only two calcimiric.

' In the relation of magnesia to ferrous iron, there is a general dominance of magnesia, which increases in relative amount from Class II to Class IV, all the latter rocks being domagnesic, while most of the former are magnesiferrous or doferrous.

Analytical errors doubtless affect some of the ratios, but the general characters of the group of rocks analyzed must be correctly expressed in the symbols and stand out at a glance with great clearness.

Quantitative names.-A striking feature of the table of quantitative names is the predominance of compound names. This arises from the fact that a large majority of all rocks are transitional in some one of the four or five factors involved in the classification as far as subrang. Many are transitional in more than one respect, and were it practicable such rocks should bear more than two parts in the compound name expressing their classification. But if symbols expressing transitional character are used, the full compound term is not necessary. It is desirable, however, as my own experience indicates, to use the simple term only for the rock that has no transitional relations.

The disadvantage of a long name is self-evident, but it seems to me small compared with the advantage of the greater accuracy of characterization which is possible with the compound. Naturally, this can not be carried too far. Compound names are often recognized as desirable in the mineralogical system, and manifestly must come into frequent use if the names of that system are really defined, with bounds.

The relations of the various rocks belonging to camptonose, ornose, and auvergnose are pretty clearly indicated by the names of the table, but still more effectively by the symbols. It should be remembered that the last name of a compound is that of the subrang to which a given rock strictly belongs, and that the first name indicates transitional relations which may exist either in subrang, rang, order, or class.

Groups under the quantitative system.-When the data brought together in the table of ratios, symbols, and names are reviewed the chemical characteristics of the analyzed rocks, as interpreted by the normative calculations, are clearly brought out. The largest group of rocks of closely allied normative composition embraces those, 18 in number, belonging to auvergnose 
(8), camptonose (6), and ornose (4). Considering first the salic molecules, through which this classification as far as subrang is reached, we may place these rocks either in the alkalicalcic rang camptonase or the docalcic rang auvergnase. The ratios show.that 8 out of the 10 rocks falling in camptonase belong in the more calcic half and that 7 out of 8 in auvergnase come in its. less calcic half. That means that 15 rocks of these adjacent rangs fall within a range equal to that of a rang.

The 18 rocks of this group are all dosodic or persodic and fall, in fact, within a range equal to that of a full subrang.

As to the femic constituents there is also a close correspondence between most of the rocks of this group. Twelve fall in the dopolic grad, five others are in the narrow transitional zones on either side, and one is perpolic.

The ratios of pyroxene to olivine bring 12 of these rocks in the perpyric section, five in the dopyric division; two of these being transitional to perpyric, and but one is pyrolic.

That magnesia and iron strongly dominate over lime in the femic molecules of this group is shown by the fact that 17 out of 18 rocks belong in the domiric subgrad, while the remaining one is permiric.

The relation of magnesia to iron is shown by the reference of 12 of these rocks to the adjacent transitional zones, while five are strongly domagnesic and but one is markedly doferrous.

The next most important group of the analyzed rocks comes in Class II and represents the dosalic lavas corresponding to camptonose in being alkalicalcic and dosodic. Five rocks fall in subrang andose (II.5.3.4) and three others are transitional to it. 'This is not so homogeneous a group as the larger one just discussed. But two rocks belong in the central division of andose. Two are in the transitional zone to the percalcic subrang beerbachose, corresponding to ornose. Three are transitional as regards class, being very near camptonose. One is transitional to the lendofelic subrang salemose (II.6.3.4).

The rocks belonging in or adjacent to andose viary considerably in their femic constituents, as the ratios and symbols show. They represent in the main a gradation from the more femic camptonose to the more salic akerose.

Akerose, the domalkalic subrang adjacent to andose, is represented by three rocks, while two others are transitional to it. Kilauose, the corresponding subrang of Class III, has the same representation. These are the domalkalic rocks and all retain the dosodic character. One akerose is transitional to the persalic larvikose.

The rocks of Class IV are similar in their femic characters, but differ notably in the salic constituents, two being peralkalic and four docalcic. The peralkalic rocks are also perlenic.

\section{DISTRIBUTION AND ASSOCIATION OF HAWAIIAN ROCKS.}

\section{IN THE HAWAIIAN GROUP.}

General distribution.-It is evident from the statements of the first part of this paper that each of the larger islands contains several kinds of rocks showing important differences in both chemical and mineral composition. The converse proposition is also true, that several kinds of rocks are known in all or nearly all the larger islands. But our knowledge concerning all the centers of eruption is so meager that we may well assume that nearly all the varieties described, and perhaps some others, actually occur on each of the principal islands.

From the accompanying table the reader may quickly see the facts of known distribution for the entire Hawaiian group. Basaltic lavas of several varieties are the most common, but, as appears in further discussion of the rocks thus far analyzed, there is a great range in the composition of the basalts and we do not yet know to what extent the basalts of individual centers have peculiarities of their own. One notable apparent limitation is that of the bronzite basalts, which are especially abundant in Oahu, at both of the great centers, and are at least rare in other islands. The melilite-nephelite basalts have been found on three islands and may well be 
present on all, among the products of recent and subsidiary eruptions. Possibly that stage of differentiation and eruption which these rocks represent has not yet been reached on Hawaii, unless perhaps in Kohala, the oldest and least-known center. Not much attention has been paid to the products of the minor and recent eruptions of Kauai, Oahu, and other extinct centers, but wo can reasonably assume from general experience that they are, as a rule, notably more mafic or more felsic than the lavas of older eruptions. The discovery in other islands of a variety equal to that occurring in the vicinity of Honolulu may plausibly be expected.

Felsic lavas which may be considered as complementary to the highly mafic lavas of Oahu and Kauai have not yet been found on those islands. The trachytes of Puu Waawaa, on Hawaii, and of Lahaina, on Maui, however, represent in a general way such felsic magmas, and the occurrence of nephelite-melilite basalt with the trachyte of Lahaina indicates the genetic connection.

Xenoliths of peridotite and pyroxenite are reported from Kauai, Oahu, Molokai, and Hawaii and doubtless occur in other places.

Distribution of rocks in Hawaiian Islands.

\begin{tabular}{|c|c|c|c|c|c|c|c|}
\hline \multirow[b]{2}{*}{ 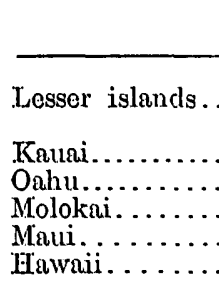 } & Soda trachyte. & \multicolumn{2}{|c|}{ Oligoclase rocks. } & Trachydolerite. & Olivine-poor basalts. & Bronzite basalts. & Normal basalts. \\
\hline & $\begin{array}{l}\text { Lahaina..... } \\
\text { Puu Waawaa. }\end{array}$ & $\begin{array}{l}\text { Kauai } \\
\text { K..... }\end{array}$ & aite... & $\begin{array}{l}\text { Haleakala . } \\
\text { Mauna Kea. }\end{array}$ & 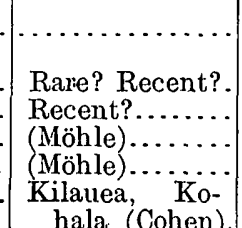 & $\begin{array}{l}\text { Common........ } \\
\cdots \ldots \ldots \\
\cdots\end{array}$ & $\begin{array}{l}\text { Laysan Ne ckar } \\
\text { (Möhle). } \\
\text { Common. } \\
\text { Rare? } \\
\text { Common (Möhle). } \\
\text { West Maui (Möhle). } \\
\text { Common. }\end{array}$ \\
\hline & Picritic basa & & Lim & burgite. & Nephelite basalt. & $\begin{array}{l}\text { Nephelite. melilite } \\
\text { basalt. }\end{array}$ & Peridotitic xenoliths. \\
\hline $\begin{array}{l}\text { Kauai..... } \\
\text { Oahu ..... }\end{array}$ & & & $\begin{array}{l}\text { Probab. } \\
\ldots \ldots\end{array}$ & ly rare. & $\begin{array}{c}\text { Several } \\
\text { rences. }\end{array}$ & $\begin{array}{l}\text { One occurrence... } \\
\text { Several occur- } \\
\text { rences. }\end{array}$ & $\begin{array}{l}\text { In limburgite. } \\
\text { Salt Lake craters. }\end{array}$ \\
\hline $\begin{array}{l}\text { Molokai. . . . . } \\
\text { Maui............ } \\
\text { Hawaii......... }\end{array}$ & $\begin{array}{l}\text { Haleakala. } \\
\text { Mauna Loa, Ki }\end{array}$ & lauea. & & & & Lahaina (Möhle) & $\begin{array}{l}\text { Mauna Kea, Hua- } \\
\text { lalai. }\end{array}$ \\
\hline
\end{tabular}

Lack of information concerning rocks of some islands.-The rocks of islands not mentioned in the table of distribution have not been identified by any petrographer. But there is no reason to question the general correctness of the term basalt, which is usually applied to these rocks where they have received casual mention. It is rather curious that three islands in the main group have received practically no attention from geologists. Lanai and Kahoolawe, situated to the west of Maui and visible from it, the former 139 square miles in extent and 3,400 feet in elevation, the latter covering 69 square miles and rising 1,472 feet above the sea, receive bare mention by Dana ${ }^{1}$ and a brief paragraph each by Hitchcock. ${ }^{2}$ The lavas of Niihau, which lies but 15 miles southwest of Kauai, is 97 square miles in extent, and reaches 1,300 feet above the sea, are likewise without any positive identification. Nihoa, or Bird Island, situated 300 miles west-northwest of Kauai, is described by Bishop ${ }^{3}$ as embracing about 250 acres, with two summits each nearly 900 feet in elevation. While Bishop considers the island a remnant of a large volcano and reports 40 or 50 dikes observed during a brief examination, no description of the rocks has been given.

Associated lavas of Kilauea.-It is only for Kilauea that the analytical data suffice to show the prevalent character of the associated magmas at any one center for a considerable period.

1 Charncteristics of volcanoes, p. 27, New York, $1890 . \quad 2$ Hawaii and its volcanoes, 2 d ed., p. 45, Honolulu, $1911 . . \quad$. ${ }^{3}$ Idem, p. 9. 
Even at Kilauea we know little concerning lavas that are older than those exposed in the walls of the caldera, which form in fact merely the uppermost part of the volcano.

Twenty-one analyses of Kilauean lavas have been given in the table. Eleven of these represent rocks from the active center of Halemaumau, nine rocks exposed in the walls of the main caldera, and one a fragment in tuff from the crest of the rim.

The 11 lavas of Halemaumau represent a number of eruptions, from the current one back as far as 1843, at least. All are very similar in composition; in fact, 9 of them belong to the camptonose-ornose-auvergnose group (hereafter called C.-O.-A.), which has been referred to (p. 58) as the most notable rock group of the islands. Seven of these nine rocks are within a single division, having the scope of a subrang, about the center point of the C.-O.-A. group, and the other two are only a trifle too rich in orthoclase to come within this division. Of the two rocks not belonging to the C.-O.-A. group, one is a "Pele's hair," analyzed by Cohen, which is the domalkalic kilauose, adjacent to camptonose, and the other is like the C.-O.-A. group except in its high normative quartz, which brings it in order 4, vaalare.

Quartz appears in six norms of Halemaumau lavas (ranging from 0.8 to 8.46 per cent), olivine in five (3.6 to 8.3 per cent), and nephelite in one ( 2.6 per cent). It appears, then, that the lavas of Halemaumau can not be rich in olivine except with coexistent free silica. As nine of the analyses are so nearly in accord, it seems worth while to strike an average for them as representing the lavas of Halemaumau of the last 70 years fairly well. The two analyses not used in obtaining this average, Nos. 34 and 14, by Cohen and Phillips, respectively, are apparently less trustworthy. In neither is $\mathrm{TiO}_{2}, \mathrm{P}_{2} \mathrm{O}_{5}$, or $\mathrm{MnO}$ determined. Both have normative quartz, the latter containing 8.46 per cent. The former has very low alumina. The average of the other nine analyses of the C.-O.-A. group is as follows:

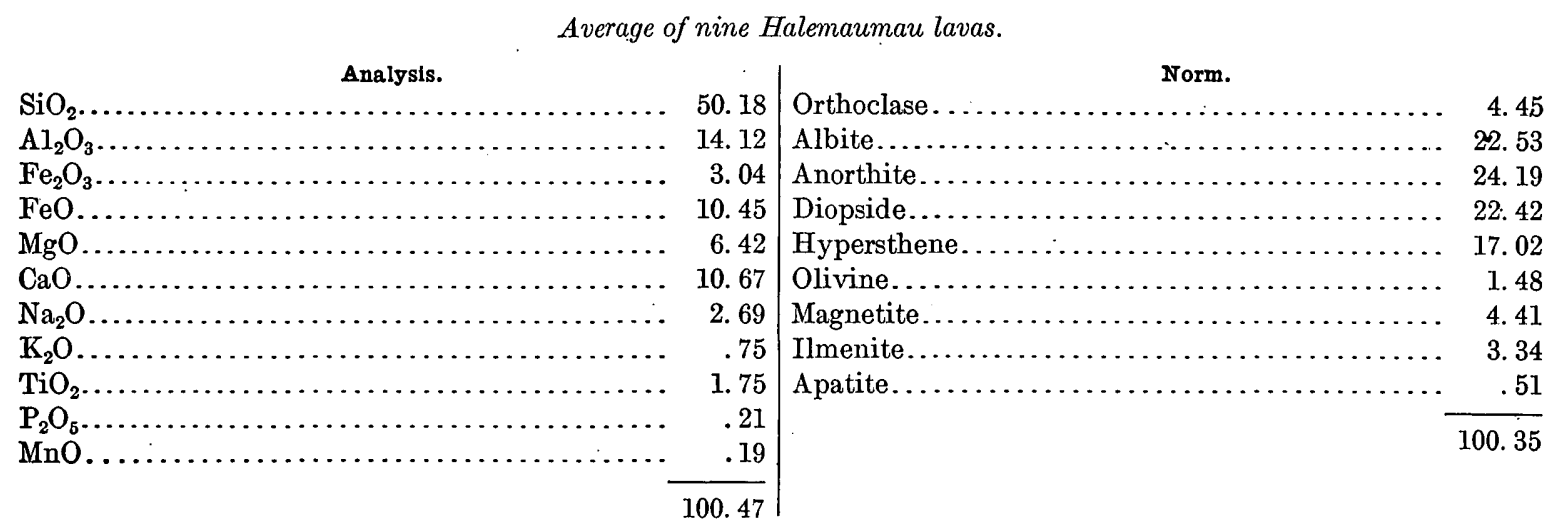

A rock of this composition would be camptonose-auvergnose, with symbol III.5.(3).4.4'. Such a magma must yield an almost olivine-free holocrystalline rock if the available silica is all utilized in forming metasilicates in preference to orthosilicates, among the femic molecules, as is supposed to be the normal condition in magmatic solutions. If the two analyses omitted had been included, $\mathrm{SiO}_{2}$ would have been increased and $\mathrm{Al}_{2} \mathrm{O}_{3}$ decreased in the average and quartz would have replaced olivine in the norm.

The table contains eight analyses, by Silvestri, of lavas from the caldera walls. Such flows must of course antedate the formation of the caldera and thus belong to a period of eruption considerably older than the historic eruptions of Halemaumau. Now, it happens that although the analyses of these older lavas are apparently very similar to those of lavas of the later epoch, the normative study reveals certain rather characteristic differences which will be discussed. As all the analyses of the older rocks were made by Silvestri, one might suspect that the difference is due to analytical methods were it not that Siltestri's two analyses of Halemaumau lavas agree with others of rocks from that center. 
The recent lavas of Halemaumau contain on the average 2.14 per cent more $\mathrm{SiO}_{2}$ than the older rocks. Only one of the recent lavas has as low $\mathrm{SiO}_{2}$ as the average of the older ones, and none of the older rocks contains as much $\mathrm{SiO}_{2}$ as the average of the recent lavas. This relation has its converse in the alumina contents of the two groups. The recent lavas have an average of 13.81 per cent and the older ones of 16 per cent of $\mathrm{Al}_{2} \mathrm{O}_{3}$. But one of the younger lavas has more than 16 per cent of $\mathrm{Al}_{2} \mathrm{O}_{3}$ and not one of the older rocks carries less than 13.97 per cent. The exceptional recent lavas, low in $\mathrm{SiO}_{2}$ and high in $\mathrm{Al}_{2} \mathrm{O}_{3}$, are not the ones analyzed by Silvestri.

These analytical differences find striking expression in the norms. The lavas of Halemaumau, with their higher silica and lower alumina, have normative quartz or low olivine, with lower feldspars and lenads. The older rocks, with less silica and more alumina, have more feldspar, lenad, and olivine, and but one has normative quartz.

These differences find still further expression in the quantitative classification of the rocks. The norms of the older lavas of the caldera wall are so rich in feldspar and nephelite, by virtue of their high alumina, that with one exception they belong in Class II or (in three cases) in the narrow transitional limits of Class III. The average of the ratio $\frac{\text { Sal }}{\text { Fem }}$ for the Halemaumau lavas is $1: 15$, for the older rocks $1: 54$, and these figures, striking as they are, probably fail to emphasize this difference sufficiently, for one exceptional rock in each group is open to suspicion. The most salic of the Halemaumau rocks is a stalagmite from a lava cave (No. 14) analyzed by Phillips. It is natural to suppose that the drippings in this cavern were richer in $\mathrm{SiO}_{2}$ than the average of the flow. If this analysis, which is not of high grade in other respects, is excluded the average $\frac{\mathrm{Sal}}{\mathrm{Fem}}$ for the recent lavas is lowered to $1: 10$.

The exceptional rock for the older group is the "kilaueite' of Silvestri, an aphanitic saccharoidal basalt which is classified as auvergnose and belongs in the C.-O.-A. group embracing most of the Halemaumau lavas. As Silvestri's specimens were not collected by a geologist the suspicion may be entertained that this kilaueite represents a flow from Halemaumau that reached the foot of the caldera wall. If this rock is stricken from the list of older lavas the average ratio $\frac{\mathrm{Sal}}{\mathrm{Fem}}$ for them becomes $1: 64$.

The classification of the older lavas is as follows:
9. Kilauose-akerose
II(III).5(6).3.4 (olivine 9.3)

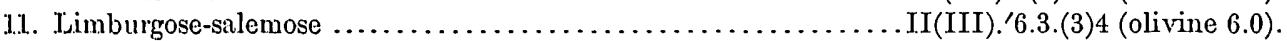

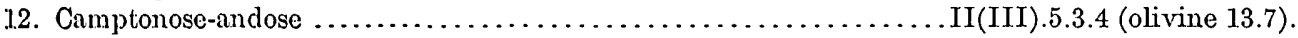

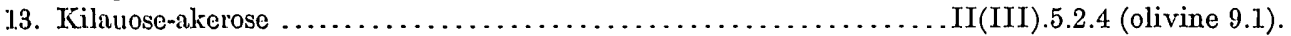

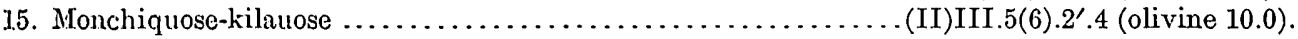
16. Andose-camptonose.......................................... (II)III.5.3.4' (olivine 3.1).
1.7. Auvergnose-camptonose..................................... (II)III.5.3(4).4 (olivine 2. 7).

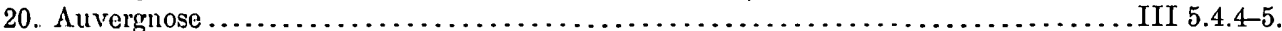

If the last-named rock, the kilaueite, is omitted, the older lavas of Kilauea are shown by the data given to form a group notably different from the lavas of Halemaumau. The normative olivine content, which is doubtless less, if anything, than the modal, makes them apparently typical basalts, though high in feldspars. True, one of them, No. 6, is called "andesite augitica" by Silvestri, though it has 6 per cent normative olivine.

What may be the significance of this difference between the lavas of different periods of eruption remains to be determined. The rocks considered do not represent the complete range of lavas erupted in these two periods, for Dana found a lava very rich in olivine at the base of Waldrons Ledge, and Daly's gabbro of Uwekahuna is also very highly femic. Then, too, the olivinic lava of 1840, in Puna, was apparently connected with Kilauea. (See p. 43.) 
WORLD DISTRIBUTION OF HAWAIIAN MAGMATIC TYPES.

Method of study of distribution.-It is proposed to set forth in this part of the discussion the results of an examination of the occurrence and association in other parts of the world of igneous rocks which are most nearly like the Hawaiian lavas in chemical composition. The rocks selected as analogues of Hawaiian types are by no means identical with them in chemical composition, but they approximate identity more closely than any other rocks that have come to my notice. The analogues have been chosen on the basis of similarity in norms rather than in analyses, as it is through the norm that the significance of the several differences between analyses may best be understood.

The approach to chemical identity between the rocks compared naturally varies somewhat with the number of analyses available for comparison or the abundance of the given variety. But in general the degree of similarity is much greater than that which is commonly considered significant by petrographers discussing relationships in special cases. In fact, most of the similarities to be pointed out are as great as the decided correspondence between different lavas of Halemaumau erupted during the last 60 years.

Many analyses and norms have been copied from. Washington's well-known Tables ${ }^{1}$ and such norms have generally not been recalculated and no further reference is deemed necessary. I am greatly indebted to Dr. Washington for placing at my disposal a number of his own unpublished analyses of rocks from: Sardinia and Pantelleria, as well as numerous calculations of norms made by him from analyses found in recent publications, in the course of preparation for a new edition of his invaluable Tables. The original sources of these analyses are not given. 
Analogues of Hawaiian lavas.

I.

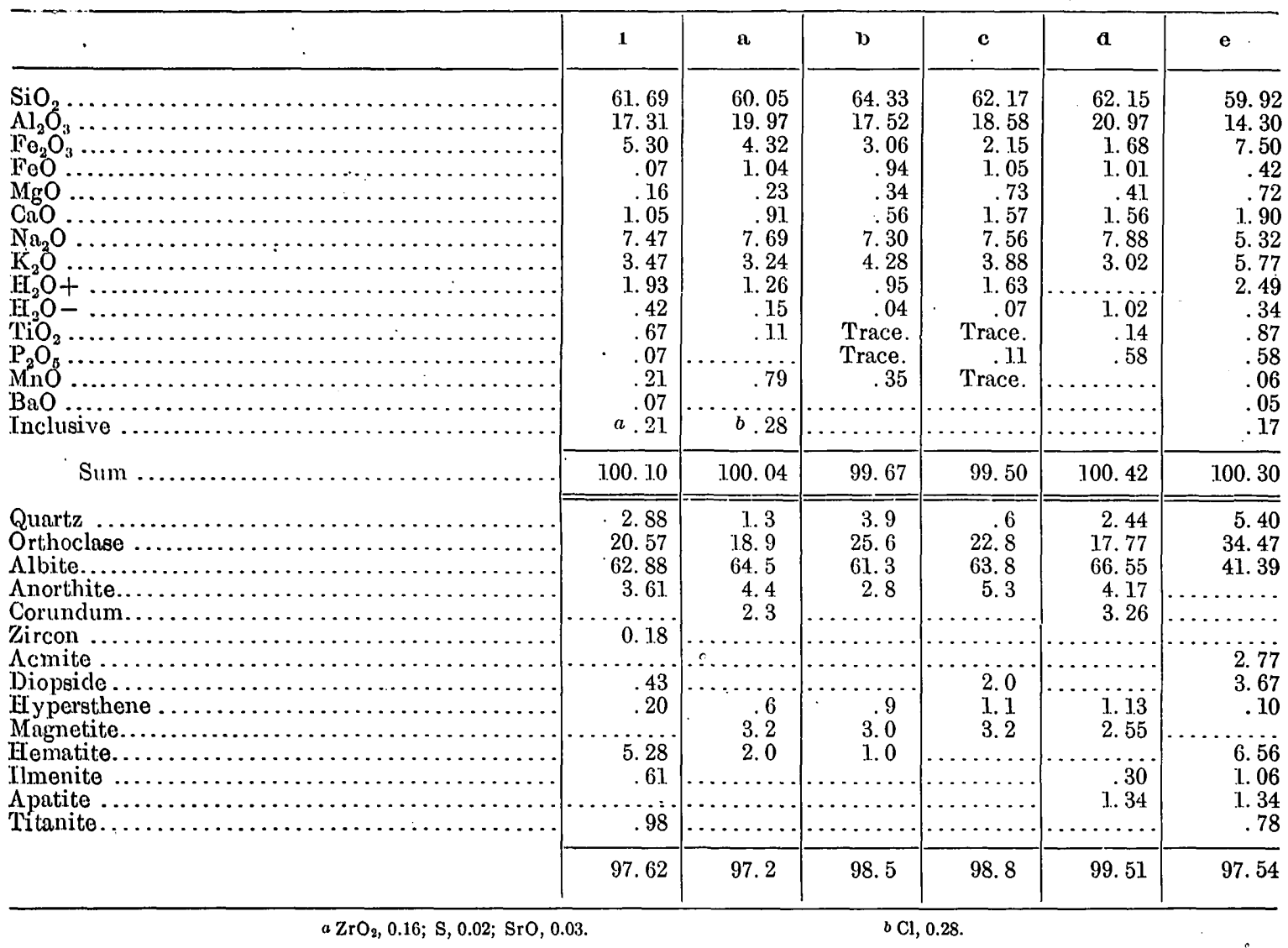

1. Soda trachyte, nordmarkose, $1^{\prime} \cdot 5.1^{\prime} .4$. Cone near Lahaina, west coast of Maui (p. 27).

a. Biotite tinguaite (Eakle). Gales Point, Essex County, Mass.

b. Acmite trachyte (Wolff and Tarr). Sixteenmile Creek, Crazy Mountains, Mont.

c. Acmite trachyte (Wolff and Tarr). Northern part of Crazy Mountains, Mont.

d. Trachyte (Schneiderhöhn), nordmarkose, I.5.1.4. Haarweiden, Westerwald, Hesse-Nassau.

e. Trachyte (Washington), ilmenose, 'II.5.1.3. Monte Muradu, Macomer, Sardinia. 
Analogues of Hawaiian lavas-Continued.

I-Continued.

\begin{tabular}{|c|c|c|c|c|c|c|c|}
\hline & 2 & $\mathbf{a}$ & $\mathbf{b}$ & $\mathbf{c}$ & $\mathbf{d}$ & $\mathbf{e}$ & $\mathbf{P}$ \\
\hline 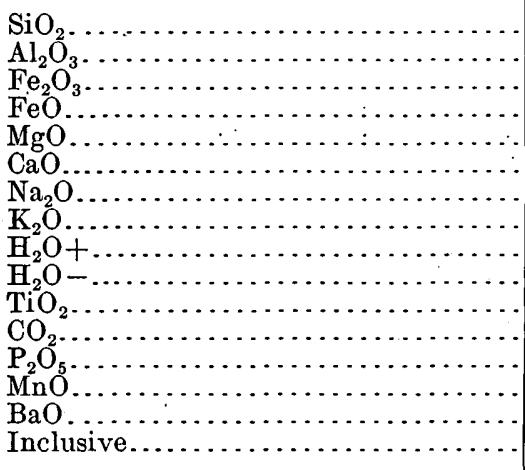 & $\begin{array}{r}62.19 \\
17.43 \\
1.65 \\
2.64 \\
.40 \\
.86 \\
8.28 \\
5.03 \\
.39 \\
.14 \\
.37 \\
.02 \\
.14 \\
.32 \\
.03 \\
\ldots . . .\end{array}$ & $\begin{array}{r}64.28 \\
15.97 \\
2.91 \\
3.18 \\
.03 \\
.85 \\
7.28 \\
5.07 \\
.20 \\
.50 \\
\ldots \ldots \\
\ldots \ldots \\
\ldots \ldots . . . \\
.12\end{array}$ & $\begin{array}{r}62.70 \\
16.40 \\
3.34 \\
2.35 \\
.79 \\
.95 \\
7.13 \\
5.25 \\
.70 \\
\ldots \ldots \\
.92 \\
\ldots \ldots \ldots \\
\ldots \ldots \ldots \\
\ldots \ldots . . . \\
\ldots \ldots\end{array}$ & 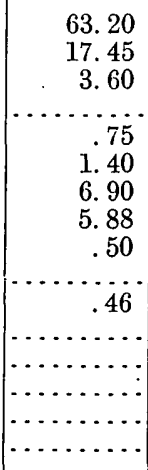 & $\begin{array}{r}63.24 \\
17.98 \\
2.67 \\
.85 \\
.63 \\
.93 \\
6.27 \\
5.47 \\
.80 \\
.37 \\
.38 \\
\ldots . . \\
.22 \\
.04 \\
.25 \\
.03\end{array}$ & $\begin{array}{r}60.50 \\
18.20 \\
1.34 \\
1.89 \\
1.18 \\
1.75 \\
7.25 \\
4.45 \\
2.30 \\
.92\end{array}$ & $\begin{array}{r}63.43 \\
16.31 \\
2.04 \\
3.14 \\
.78 \\
1.70 \\
6.71 \\
4.31 \\
.18 \\
.26 \\
1.19 \\
\text { None. } \\
.20 \\
.04 \\
.05 \\
.11\end{array}$ \\
\hline 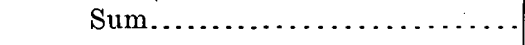 & 99.93 & 100.33 & 100.53 & 100.14 & 100.14 & 99.78 & 100.45 \\
\hline 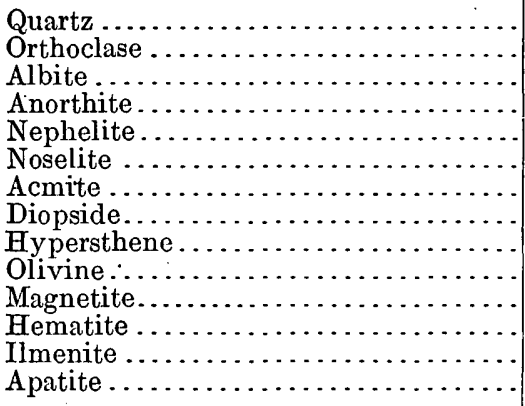 & 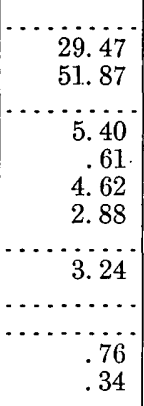 & 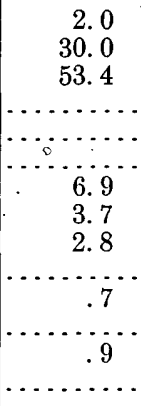 & 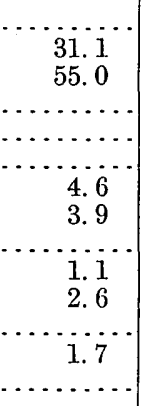 & 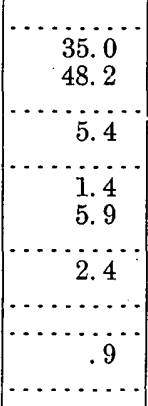 & 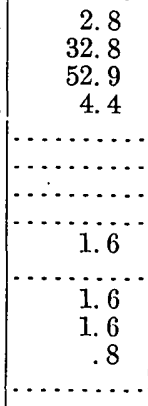 & 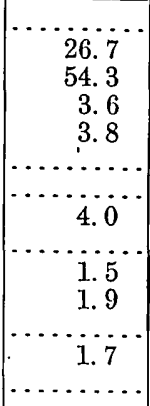 & $\begin{array}{r}3.9 \\
25.6 \\
56.6 \\
1.7 \\
\ldots \ldots . . \\
\ldots \ldots . . \\
\ldots \ldots \\
4.8 \\
1.6 \\
3.0 \\
\ldots \ldots \\
2.3 \\
2.3 \\
.3\end{array}$ \\
\hline & 99.19 & 100.4 & 100.0 & 99.2 & 98.5 & 97.5 & 99.8 \\
\hline
\end{tabular}

2. Trachyte obsidian, nordmarkose-umptekose, (I)II.5'.1.4. Puu Waawaa, island of Hawaii (p. 35).

a. Glaucophane-sölvsbergite (Washington), ilmenose-umptekose, (I)II.5.1.(3)4. Andrews Point, Cape Ann, Essex County, Mass.

b. Hornblende sölvsbergite (Brögger), ilmenose-umptekose, (I)II.5.1.(3)4. Laugendal, Christiania district, Norway.

c. Nordmarkite (Brögger), phlegrose-nordmarkose, I(II).5'.1.(3)4. Tonsenas, near Christiania, Norway.

d. Biotite trachyte (Hague and Jaggar), phlegrose-nordmarkose, I.5.1.(3)4. Dike Mountain, Yellowstone National Park.

e. Phonolite (Lacroix), nordmarkose, $\mathrm{I}^{\prime} \cdot 5 \cdot 1^{\prime} .4$. Vaïrao, Tahiti.

f. Trachyte (Washington), umptekose-nordmarkose, I(II).5.1.4. Montagne Grande, Pantelleria. 
.Analogues of Hawaiian lavas-Continued.

II.

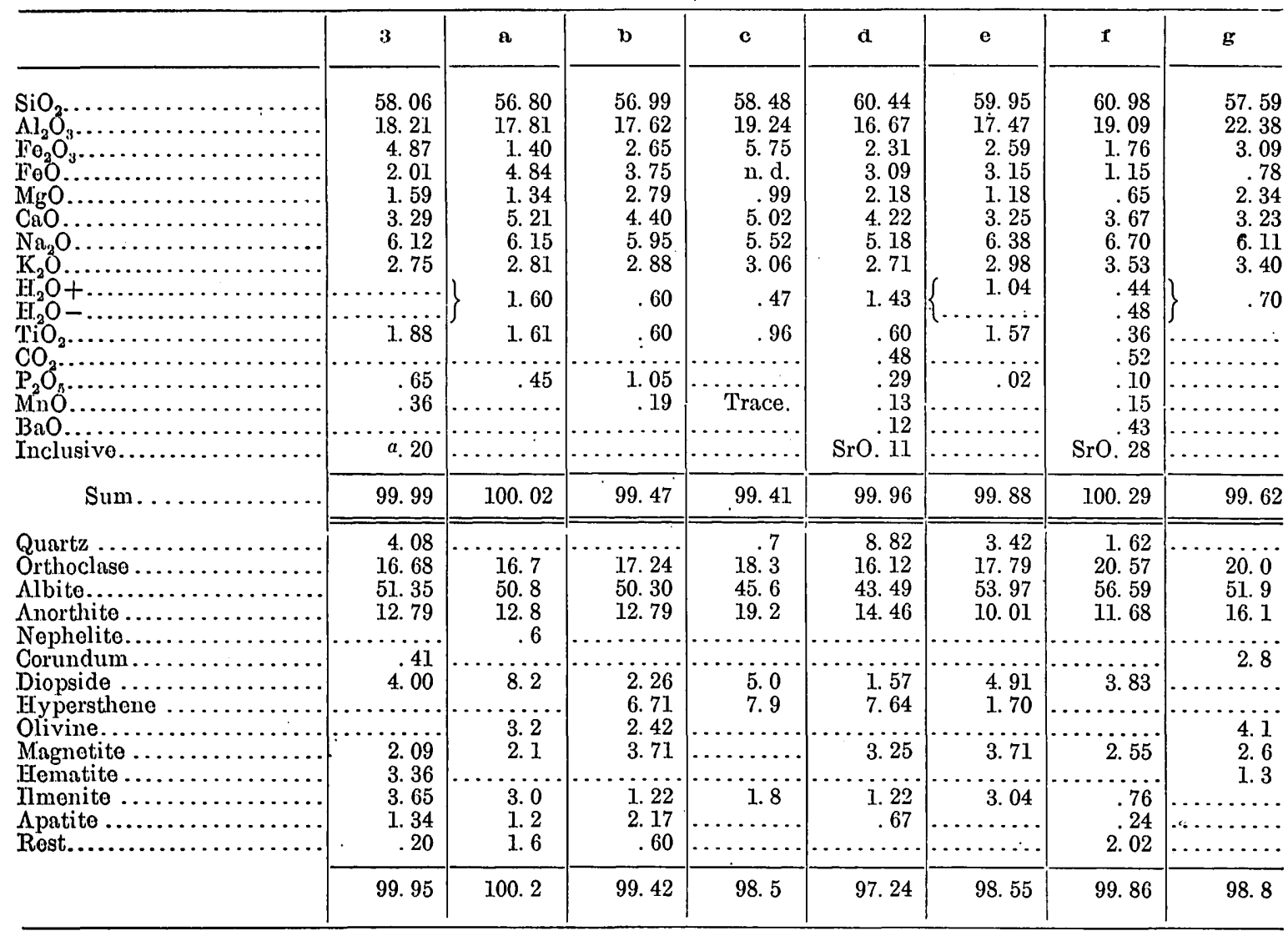

$a \mathrm{CuO}, 0.10 ; \mathrm{SO}_{3}, 0.05 ; \mathrm{S}, 0.05$.

3. Foldspathic lava (Lyons), larvikose-akerose, (I)II.5.2.4. Kohala Mountain, near Waimea, island of Hawaii.

a. Leeuwfonteinite (Brouwer), akerose, 'II.5.2.4. Leeuwfontein, Pretoria district, Transvaal.

b. Natron-minette (Hackmann), akerose, 'II.5.2.4. Autionsaari, Tavajärvi, Kuusamo, Finland.

c. Akerito (Brögger), andose-akerose, (I)II.5.2(3).4. Ramnäs, Christiania region, Norway.

d. Quartz monzonite porphyry (Cross), dacose-akerose, (I)II.(4)5.2'.4. Dike, Deadwood Gulch, La Plata Mountrins, Colo.

๑. Akerite (Lacroix), larvikose-akerose, (I)II.5.2.4. Bras Rouge, Cilaos, Reunion Island.

f. Monzonite porphyry (Cross), larvikose, I'.5.2.4. Dike, north spur of Mount Pennell, Henry Mountains, Utah.

g. Augite syenite (Brögger), larvikose, I'.5.2.4. Fagerheimasen, Notterö, Norway.

$48730^{\circ}-15-5$ 
Analogues of Hawaiian lavas-Continued.

III.

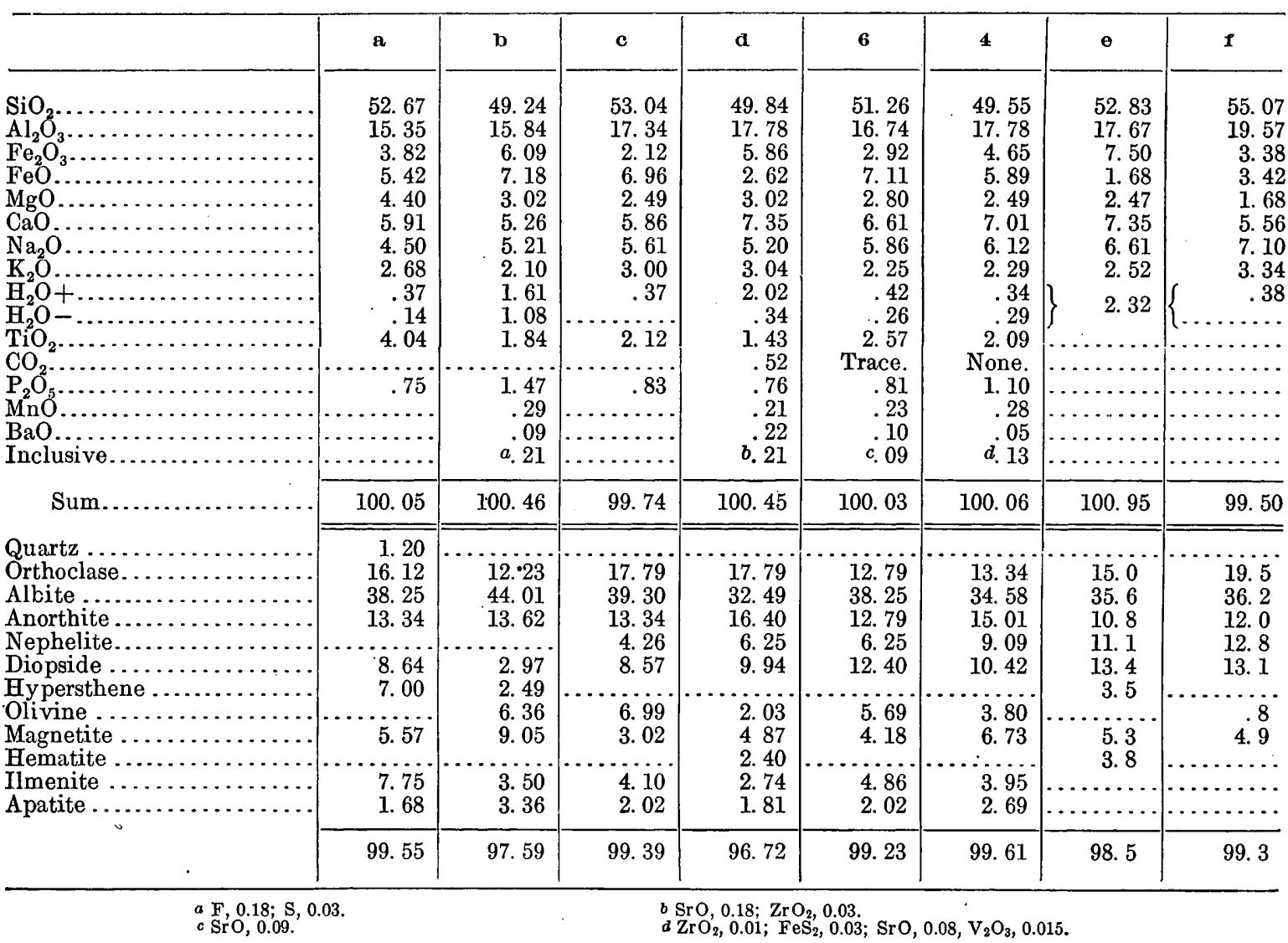
a. Basalt (Washington), akerose, II.5.2'.4. Mount San Mateo; Ploaghe, Sardinia.
b. Mugearite (Harker), akerose, II.5.2'.4. Island of Skye, Scotland.
c. Olivine trachyandesite (Lacroix), akerose, II.5.2.4. Bellouve, Reunion Island.
d. Trachydolerite (Graton), akerose, II. $5^{\prime} .2^{\prime} .4$. Bull Cliff, Cripple Creek district, Colo.
6. Trachyandesite (Cross), akerose, II.5'.3.4. Vieira's ranch, south of Kaupo Gap, Haleakala, Maui.
4. Trachyandesite (Cross), akerose-essexose, II.(5)6.2.4. White Hill, crater of Haleakala, Maui.
e. Carmeloite (Lawson), akerose-essexose, II.(5)6.2.4. Sunium Point, Carmelo Bay, Cal.
f. Rhombenporphyr (Brögger), essexose, II.6'.2.4. Stoksund, Norway. 
Analogues of Hawaiian lavas-Continued.

IV.

\begin{tabular}{|c|c|c|c|c|c|c|c|c|c|c|}
\hline & c & a & - & I & 5 & 7 & g & $\mathbf{h}$ & 1 & J \\
\hline 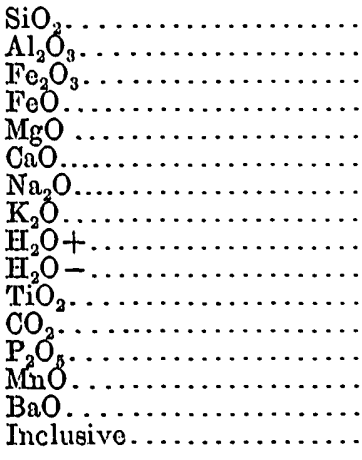 & \begin{tabular}{r}
48.67 \\
16.88 \\
4.98 \\
6.37 \\
4.62 \\
8.63 \\
3.85 \\
1.26 \\
.32 \\
.02 \\
2.12 \\
\hdashline. .35 \\
$1.8 \ldots$
\end{tabular} & $\begin{array}{r}48.63 \\
1.01 \\
2.92 \\
8.85 \\
3.87 \\
7.90 \\
3.98 \\
1.76 \\
.22 \\
4.02 \\
.77 \\
\ldots . . . . . \\
\ldots . . .\end{array}$ & $\begin{array}{r}47.61 \\
17.47 \\
3.44 \\
8.78 \\
2.49 \\
7.04 \\
4.49 \\
1.60 \\
3.71 \\
.84 \\
.87 \\
.28 \\
1.10 \\
.13\end{array}$ & $\begin{array}{r}52.18 \\
18.19 \\
3.31 \\
4.36 \\
4.69 \\
5.61 \\
4.58 \\
1.83 \\
2.00 \\
.75 \\
.99 \\
\text { None. } \\
.29 \\
.14 \\
.11 \\
.06\end{array}$ & $\begin{array}{r}50.92 \\
1759 \\
3.80 \\
6.69 \\
3.90 \\
6.97 \\
4.28 \\
1.86 \\
.79 \\
.35 \\
2.55 \\
\ldots . .30 \\
.420 \\
\ldots \ldots \ldots \\
\ldots \ldots .\end{array}$ & $\begin{array}{r}49.73 \\
16.39 \\
7.58 \\
3.98 \\
4.06 \\
7.17 \\
4.12 \\
1.93 \\
.81 \\
.54 \\
3.05 \\
\text { None. } \\
.84 \\
.23 \\
.03 \\
.07\end{array}$ & $\begin{array}{r}52.92 \\
17.70 \\
3.16 \\
4.48 \\
4.34 \\
5.90 \\
4.08 \\
2.24 \\
1.42 \\
\cdots . .94 \\
\ldots .9 \\
.18 \\
\text { Trace. } \\
\ldots . .0 \\
.09\end{array}$ & $\begin{array}{r}56.47 \\
15.33 \\
2.54 \\
4.53 \\
5.08 \\
6.93 \\
3.81 \\
1.66 \\
1.65 \\
\ldots .99 \\
.99 \\
.54 \\
.18 \\
\ldots \ldots . . \\
\ldots \ldots\end{array}$ & $\begin{array}{r}54.70 \\
18.05 \\
3.63 \\
3.31 \\
3.90 \\
6.36 \\
4.08 \\
1.97 \\
3.28 \\
\ldots 1.09 \\
\ldots \ldots \ldots \\
\text { Trace. } \\
\ldots \ldots \ldots . . . \\
.13\end{array}$ & 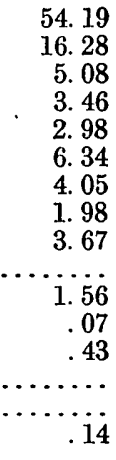 \\
\hline Sum. & 99.57 & 99.93 & 99.85 & 100.04 & 100.30 & 100.53 & 100.45 & 99.71 & 100.50 & 100.23 \\
\hline $\begin{array}{l}\text { Quartz....... } \\
\text { Orthoclase.... } \\
\text { Albite....... } \\
\text { Anorthite.... } \\
\text { Nephelite.... }\end{array}$ & $\begin{array}{l}10.0 \\
32.5 \\
23.9\end{array}$ & $\begin{array}{l}10.6 \\
34.1 \\
22.2\end{array}$ & $\begin{array}{r}9.5 \\
36.7 \\
22.5 \\
.8\end{array}$ & $\begin{array}{l}11.1 \\
38.8 \\
23.4\end{array}$ & $\begin{array}{l}\text { i1. } 1 \\
36.2 \\
23.4\end{array}$ & $\begin{array}{r}1.7 \\
11.1 \\
34.6 \\
20.9\end{array}$ & $\begin{array}{r}3.5 \\
13.9 \\
34.6 \\
23.1\end{array}$ & $\begin{array}{r}6.8 \\
10.0 \\
32.0 \\
22.5\end{array}$ & $\begin{array}{r}4.7 \\
11.7 \\
34.6 \\
25.0\end{array}$ & $\begin{array}{r}8.0 \\
11.7 \\
34.1 \\
20.6\end{array}$ \\
\hline 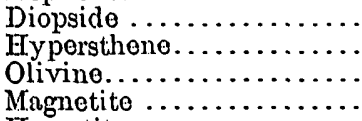 & $\begin{array}{r}5.6 \\
10.3 \\
2.0 \\
7.2\end{array}$ & $\begin{array}{r}10.0 \\
1.1 \\
8.0 \\
4.2\end{array}$ & $\begin{array}{r}4.2 \\
\because 32.2 \\
4.9\end{array}$ & $\begin{array}{l}7.2 \\
3.8 \\
5.8 \\
4.9\end{array}$ & $\begin{array}{l}6.8 \\
7.3 \\
3.2 \\
5.6\end{array}$ & $\begin{array}{l}7.1 \\
6.9\end{array}$ & $\begin{array}{r}5.0 \\
12.0\end{array}$ & $\begin{array}{r}6.8 \\
14.0\end{array}$ & $\begin{array}{l}5.4 \\
8.6 \\
5.1\end{array}$ & $\begin{array}{r}6.5 \\
4.5 \\
7.4\end{array}$ \\
\hline 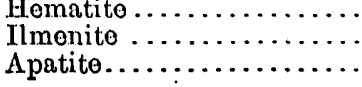 & $\begin{array}{l}3.9 \\
4.4\end{array}$ & $\begin{array}{l}7.6 \\
1.7\end{array}$ & $\begin{array}{l}1.7 \\
2.7\end{array}$ & 1.8 & $\begin{array}{l}4.9 \\
1.0\end{array}$ & $\begin{array}{l}4.5 \\
5.8 \\
2.0\end{array}$ & $\begin{array}{c}1.7 \\
\ldots \ldots\end{array}$ & $\begin{array}{l}1.8 \\
1.2\end{array}$ & $\begin{array}{c}2.0 \\
2 .\end{array}$ & $\begin{array}{l}2.99 \\
1.0\end{array}$ \\
\hline & 99.8 & 99.5 & 95.3 & 96.8 & 99.5 & 99.2 & 98.4 & 98.5 & 97.1 & 96.7 \\
\hline
\end{tabular}

c. Norite (Pirsson), camptonose-andose, II(III).5.3.4. Slide Brook, Waterville, N. H.

d. Basalt (Lacroix), andose, II.5.3.4. Avirons, Reunion Island.

e. Porphyrite (Sheight and Finlayson), andose, II.5.3.4. Carnley Harbor, Auckland Islands.

f. Diabase (Hague and Jaggar), andose. Shoshone Canyon, Yellowstone National Park.

5. 'Trachydolerite (Daly), andose, $\mathrm{II}^{\prime}$.5.3.4. Poliahu Cone, near summit of Mauna Kea, Hawaii.

7. Andesitic basalt (Daly), andose, II.5.3.4. At 11,000 feet S. $75^{\circ}$ E. of summit of Mauna Kea, Hawali.

g. Hornblende andesite (Iddings), andose. Sepulcher Mountain, Yellowstone National Park.

h. Pyroxene andesite (Iddings), andose. Near Dunraven Peak, Yellowstone National Park.

i. Porphyrite (Lossen), andose. Heichweiler, St. Wendel, Harz Mountains, Germany.

j. Basalt (Lossen), andose. Idarthal, St. Wendel, Harz Mountains, Germany. 
Analogues of Hawaiian lavas-Continued.

v.

\begin{tabular}{|c|c|c|c|c|c|c|c|c|c|c|}
\hline & $\mathbf{a}$ & b & c & d & e & 8 & 10 & $\mathbf{r}$ & g & h \\
\hline 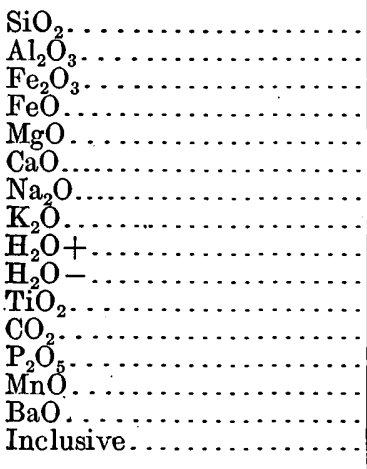 & $\begin{array}{r}55.08 \\
18.93 \\
2.02 \\
5.56 \\
5.17 \\
8.40 \\
4.23 \\
.74 \\
.29 \\
\ldots \ldots . .\end{array}$ & $\begin{array}{r}50.33 \\
19.97 \\
2.81 \\
6.23 \\
3.24 \\
8.03 \\
4.30 \\
1.19 \\
.99 \\
.87 \\
1.81 \\
.17 \\
.17 \\
.06\end{array}$ & $\begin{array}{r}52.79 \\
16.45 \\
2.74 \\
6.44 \\
5.56 \\
6.51 \\
3.64 \\
1.21 \\
1.02 \\
. .21 \\
2.64 \\
\ldots . .39 \\
.06 \\
. .018 \\
.18\end{array}$ & $\begin{array}{r}50.45 \\
18.90 \\
7.73 \\
2.61 \\
5.41 \\
9.00 \\
3.92 \\
1.05 \\
.10 \\
.18 \\
.27 \\
\ldots .52 \\
. .5\end{array}$ & $\begin{array}{r}53.31 \\
20.05 \\
2.18 \\
3.37 \\
3.33 \\
8.65 \\
4.17 \\
1.30 \\
2.02 \\
1.16 \\
.06 \\
.18 \\
\cdots . . . \\
.20\end{array}$ & $\begin{array}{r}46.30 \\
17.95 \\
6.21 \\
6.79 \\
3.67 \\
8.17 \\
3.92 \\
.89 \\
\ldots . .3 \\
5.35 \\
.53 \\
.26 \\
.28\end{array}$ & \begin{tabular}{r}
49.01 \\
16.29 \\
7.61 \\
4.89 \\
3.62 \\
9.79 \\
3.82 \\
.80 \\
$\ldots \ldots \ldots$ \\
\hdashline 3.93 \\
$\ldots$. \\
.49 \\
.27 \\
$\ldots .32$ \\
.32
\end{tabular} & $\begin{array}{r}50.86 \\
15.72 \\
9.77 \\
2.48 \\
3.55 \\
10.52 \\
3.89 \\
.90 \\
2.53 \\
\ldots\end{array}$ & $\begin{array}{r}52.99 \\
16.71 \\
3.80 \\
3.55 \\
6.95 \\
8.49 \\
3.56 \\
1.29 \\
.59 \\
.18 \\
1.18 \\
\ldots .42 \\
. .42 \\
.07 \\
.14\end{array}$ & $\begin{array}{r}51.98 \\
17.20 \\
8.22 \\
2.00 \\
5.41 \\
8.17 \\
3.84 \\
.90 \\
.62 \\
\ldots . . \\
.36\end{array}$ \\
\hline Sum. & 100.42 & 100.17 & 99.84 & 100.14 & 99. 98 & 100.32 & 100.84 & 100. 22 & 99.92 & 99.6 \\
\hline $\begin{array}{l}\text { Quartz....... } \\
\text { Orthoclase.... } \\
\text { Albite ........ } \\
\text { Anorthite..... } \\
\text { Diopside..... } \\
\text { Hypersthene. } \\
\text { Olivine....... }\end{array}$ & $\begin{array}{r}.6 \\
.44 \\
35.6 \\
30.3 \\
9.2 \\
16.9\end{array}$ & $\begin{array}{r}7.2 \\
36.1 \\
31.7 \\
5.2 \\
4.6 \\
5.2\end{array}$ & $\begin{array}{r}4.5 \\
7.2 \\
30.9 \\
24.7 \\
3.8 \\
17.2\end{array}$ & $\begin{array}{r}.2 \\
6.1 \\
33.0 \\
30.9 \\
8.0 \\
9.8\end{array}$ & $\begin{array}{r}1.6 \\
7.8 \\
35.6 \\
31.7 \\
9.0 \\
6.7\end{array}$ & $\begin{array}{r}.3 \\
5.0 \\
30.0 \\
28.9 \\
6.3 \\
6.3\end{array}$ & $\begin{array}{r}3.1 \\
4.5 \\
32.0 \\
25.3 \\
15.8 \\
1.8\end{array}$ & $\begin{array}{r}3.2 \\
5.6 \\
33.0 \\
22.5 \\
19.3 \\
2.0\end{array}$ & $\begin{array}{r}2.2 \\
7.8 \\
29.9 \\
25.9 \\
11.1 \\
13.7\end{array}$ & $\begin{array}{r}4.8 \\
5.6 \\
32.5 \\
27.0 \\
5.4 \\
11.0\end{array}$ \\
\hline 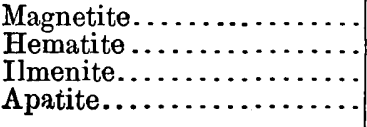 & ........... & $\begin{array}{r}4.2 \\
3 . \\
3.5 \\
.7\end{array}$ & \begin{tabular}{l}
3.9 \\
\hdashline .0 \\
1.0
\end{tabular} & $\begin{array}{r}7.7 \\
2.4 \\
.5 \\
1.3\end{array}$ & $\begin{array}{c}3.2 \\
\ldots 2.2 \\
2.2\end{array}$ & $\begin{array}{r}6.7 \\
1.6 \\
10.0 \\
1.2\end{array}$ & $\begin{array}{l}5.3 \\
4.0 \\
7.5 \\
1.2\end{array}$ & $\begin{array}{l}8.1 \\
4.2 \\
. . .\end{array}$ & $\begin{array}{l}6.6 \\
2.3 \\
1.0\end{array}$ & $\begin{array}{l}6.5 \\
3.7\end{array}$ \\
\hline . & 100.0 & 98.3 & 98.2 & 99.9 & 97.8 & 99.3 & 100.5 & 97.9 & 100.5 & 98.9 \\
\hline
\end{tabular}

a. Andesite-basalt (Diller), beerbachose. Delta, Shasta County, Cal.

b. Olivine dolerite (Harker), andose, II.5.3'.4' Druim na Criche, near Portree, island of Skye.

c. Basalt (Washington), andose. Uras, Monte Arci, Sardinia.

d. Hypersthene diorite (Chelius), beerbachose-andose, II.5.3(4).4(5). Lichtenberg, Odenwald, Hesse, Germany.

e. Dolerite (Lossen), andose. Sattel, Niederkirchen, Nahethal, Rhenish Prussia.

8. Highly feldspathic lava (Lyons), beerbachose-andose, $I^{\prime}$.5.3.4(5). Waianae Mountains, Oahu.

10. Porphyritic lava (Lyons), andose-beerbachose, II(III) $.5 \cdot 3^{\prime} .(4) 5$. Kohala Mountain, northern district of Hawaii.

f. Gabbro (Wadsworth), andose. Near Baptism River, Minn.

g. Basalt (Patton), andose. Red Cone, Crater Lake, Oreg.

h. Basalt (Hoppe), andose. Cerro de Guadalupe, Puebla, Mexico. 
Analogues of Hawaiian lavas-Continued.

V1.

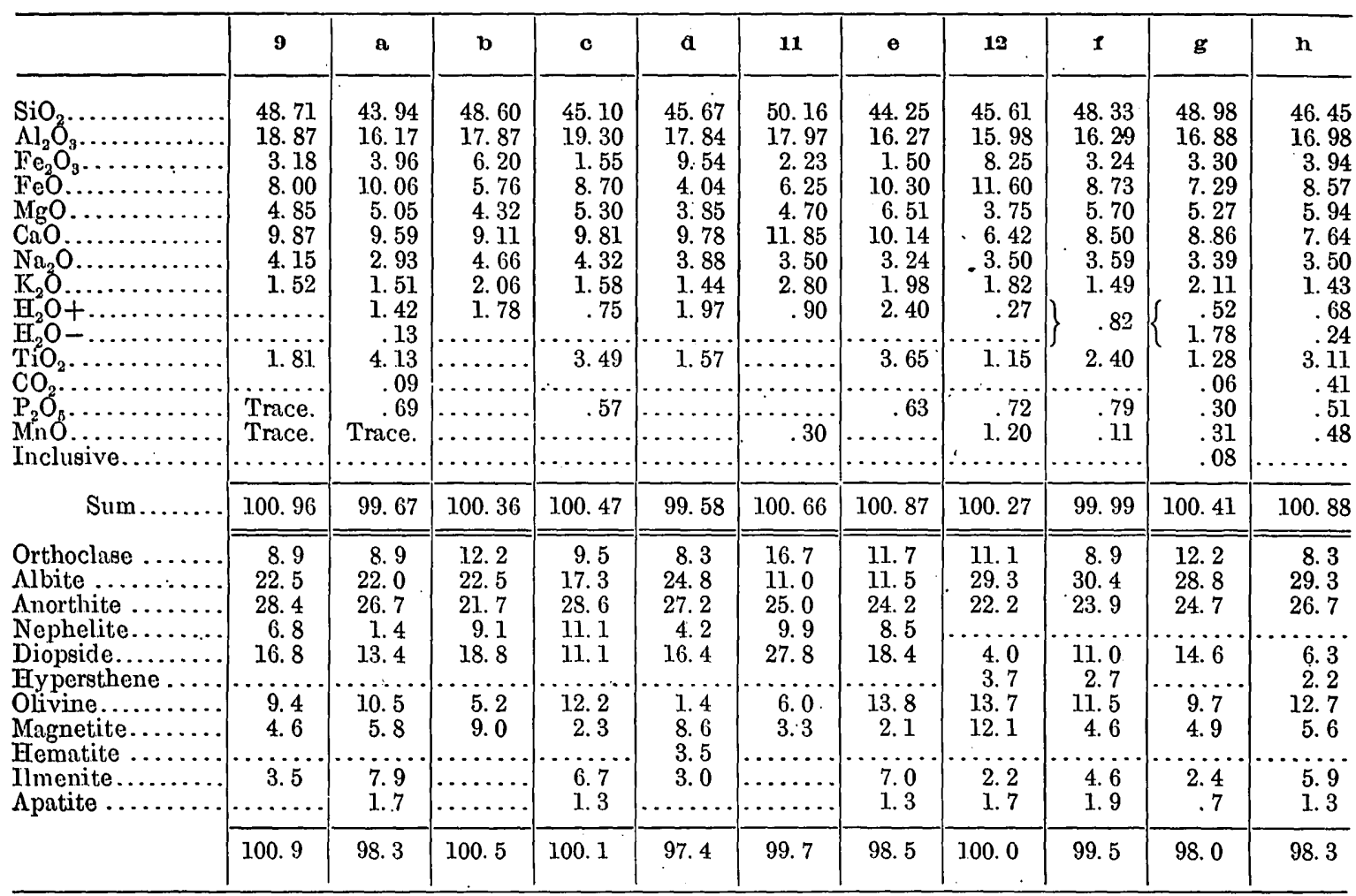

9. Basalt (Silvestri), salemose-andose, $\mathrm{II}^{\prime} .5(6) .3 .4$. Wall of caldera, Kilauea.

a. Essexite (Pirsson and Washington), andose-camptonose, (II)III.5.3(4).4. Lockes Hill, Mount Belknap, N. H.

b. Dolerite (Speight), salemose. Dyers Pass, Canterbury, New Zealand.

c. Nephelite gabbró (theralite) (Lacroix), salemose, $\mathrm{II}^{\prime}$ '6.3.4. Papenoo Valley, Tahiti.

d. Nephelite tephrite (Bücking), andose, $\mathrm{II}^{\prime} \cdot 5^{\prime}$.3.4. Suchenberg, Rhöngebirge, Germany:

11. Augite andesite (Silvestri), limburgose-salemose, II(III)' 6.3.(3)4. Wall of caldera, Kilauea.

e. Basalt (Lacroix), camptonose-limburgose, 'III.(5)6.3.4. Papenoo Valley, Tahiti.

12. Basaltoid (Silvestri), camptonose-andose, II(III).5.3.4. Wall of caldera, Kilauea.

f. Alkali feldspar bearing basaltic bomb (Kozu), camptonose-andose, II(III).5.3.4. Volcano Ondake, Tukae, Goto Tslands, Japan.

g. Olivine basalt (Card), andoee, II'.5.3.4. Northeast of St. Georges Head, New South Wales.

h. Basalt (Tyrrell), camptonose-andose, II(III).5.3'.4. Stockiemuir, Kilpatrick Hills, Scotland. 
Analogues of Bawaiian lavas-Continued.

VII.

\begin{tabular}{|c|c|c|c|c|c|c|c|c|c|}
\hline & 13 & $\mathbf{a}$ & 15 & b & c & d & 26 & e & $\mathbf{r}$ \\
\hline 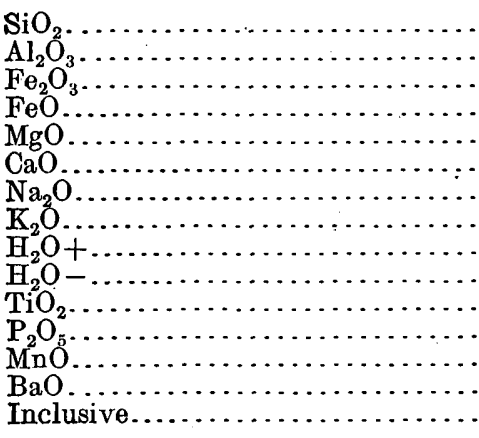 & $\begin{array}{r}49.45 \\
13.97 \\
8.10 \\
11.17 \\
1.90 \\
5.92 \\
5.05 \\
1.75 \\
1.19 \\
\ldots . . \\
.16 \\
.85 \\
\ldots . .\end{array}$ & $\begin{array}{r}52.85 \\
13.25 \\
2.36 \\
8.71 \\
6.84 \\
8.47 \\
4.72 \\
1.53 \\
.93 \\
\ldots .35 \\
.40 \\
\ldots .6 . \\
\hdashline\end{array}$ & $\begin{array}{r}47.63 \\
15.02 \\
8.15 \\
10.40 \\
3.50 \\
6.87 \\
4.92 \\
1.80 \\
.30 \\
.12 \\
.08 \\
.80 \\
\ldots . .\end{array}$ & $\begin{array}{r}49.16 \\
14.17 \\
4.62 \\
6.60 \\
7.01 \\
6.45 \\
4.61 \\
2.23 \\
4.22 \\
\cdots \\
.42 \\
.\end{array}$ & $\begin{array}{r}49.78 \\
13.37 \\
2.16 \\
7.51 \\
7.61 \\
7.95 \\
4.72 \\
2.37 \\
.34 \\
.08 \\
3.11 \\
.72\end{array}$ & $\begin{array}{r}50.15 \\
15.21 \\
1.54 \\
7.32 \\
7.54 \\
7.18 \\
4.31 \\
2.59 \\
.35 \\
.12 \\
3.37 \\
.67 \\
\hdashline .6 \% \\
\hdashline . .6\end{array}$ & $\begin{array}{r}45.81 \\
11.90 \\
4.62 \\
8.09 \\
5.39 \\
10.67 \\
4.28 \\
1.40 \\
.53 \\
.47 \\
4.05 \\
2.20 \\
.17 \\
.04 \\
.03\end{array}$ & $\begin{array}{r}44.85 \\
12.55 \\
3.33 \\
5.30 \\
10.24 \\
8.32 \\
4.77 \\
.72 \\
2.01 \\
.95 \\
5.07 \\
1.17 \\
.07 \\
.23\end{array}$ & $\begin{array}{r}46.52 \\
10.48 \\
4.40 \\
7.79 \\
10.58 \\
9.49 \\
3.12 \\
1.55 \\
1.79 \\
2.98 \\
.83 \\
.11 \\
.73\end{array}$ \\
\hline Sum... & 99.51 & 100.41 & 99.59 & 99.49 & 99.71 & 100. 35 & 99.65 & 99.60 & 100.37 \\
\hline 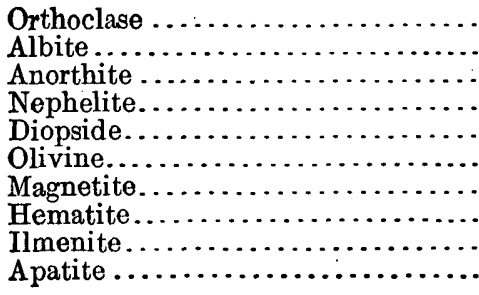 & $\begin{array}{r}10.6 \\
38.3 \\
10.0 \\
2.6 \\
15.8 \\
9.1 \\
11.8 \\
\cdots . . . \\
. .3\end{array}$ & $\begin{array}{r}8.9 \\
35.1 \\
10.6 \\
2.6 \\
23.4 \\
14.0 \\
3.5 \\
\begin{array}{r}.6 \\
1.0\end{array}\end{array}$ & $\begin{array}{r}11.1 \\
27.8 \\
13.3 \\
7.4 \\
17.5 \\
10.0 \\
11.8 \\
\cdots \cdots \\
\quad .3\end{array}$ & $\begin{array}{r}12.8 \\
29.3 \\
11.7 \\
5.1 \\
16.5 \\
12.4 \\
7.5\end{array}$ & $\begin{array}{r}13.9 \\
26.7 \\
8.3 \\
7.1 \\
21.2 \\
11.2 \\
3.3 \\
3.9 \\
5.9 \\
1.7\end{array}$ & $\begin{array}{r}15.6 \\
28.3 \\
14.2 \\
4.5 \\
13.3 \\
13.8 \\
2.3 \\
6.3 \\
6.4 \\
1.7\end{array}$ & $\begin{array}{r}8.3 \\
29.3 \\
9.2 \\
3.7 \\
23.8 \\
4.8 \\
6.7\end{array}$ & $\begin{array}{r}4.5 \\
28.3 \\
10.6 \\
6.5 \\
17.9 \\
12.2 \\
2.3 \\
1.8 \\
9.7 \\
2.7\end{array}$ & $\begin{array}{r}8.9 \\
24.1 \\
10.3 \\
1.1 \\
24.6 \\
14.8 \\
6.5 \\
9.7 \\
1.9\end{array}$ \\
\hline & 98.5 & 99.7 & 99.2 & 95.3 & 99.3 & 100.1 & 98.4 & 96.5 & 97.9 \\
\hline
\end{tabular}

13. Hornblende-basalt (Silvestri), kilauose-akerose, II(III).5.2.4. Wall of caldera, Kilauea.

a. Basalt (Hoppe), kilauose. Cerro San Miguel, Puebla, Mexico.

15. Basaltoide (Silvestri), monchiqose-kilauose, (II)III.5(6).2'.4. Wall of caldera, Kilauea.

b. Kersantite (Pohlmann), kilauose-akerose. Bärenstein, Thuringia, Germany.

c. Basalt (Washington), kilauose-monchiquose, III.(5)6.2.4. Monte Cuccuruddu, Keremale, Sardinia.

d. Basalt (Washington), kilauose-akerose, II(III). $5^{\prime} \cdot 2^{\prime} .4$. Mount Lisiri, Itirreddu, Sardinia,

26. Sodic gabbro=kauaiite (Cross), kilauose, III.5.2.4'. Waimea Canyon, Kauai.

e. Leucite basanite (Washington), kilauose. North of Scano, Monte Ferru, Sardinia.

f. Basalt (Pirsson), kilauose. Volcano Butte, Castle Mountains, Mont. 
DISTRIBUTION AND ASSOCIATION OF HAWAIIAN ROCKS.

Analogues of Hawaiian lavas-Continued.

VIII.

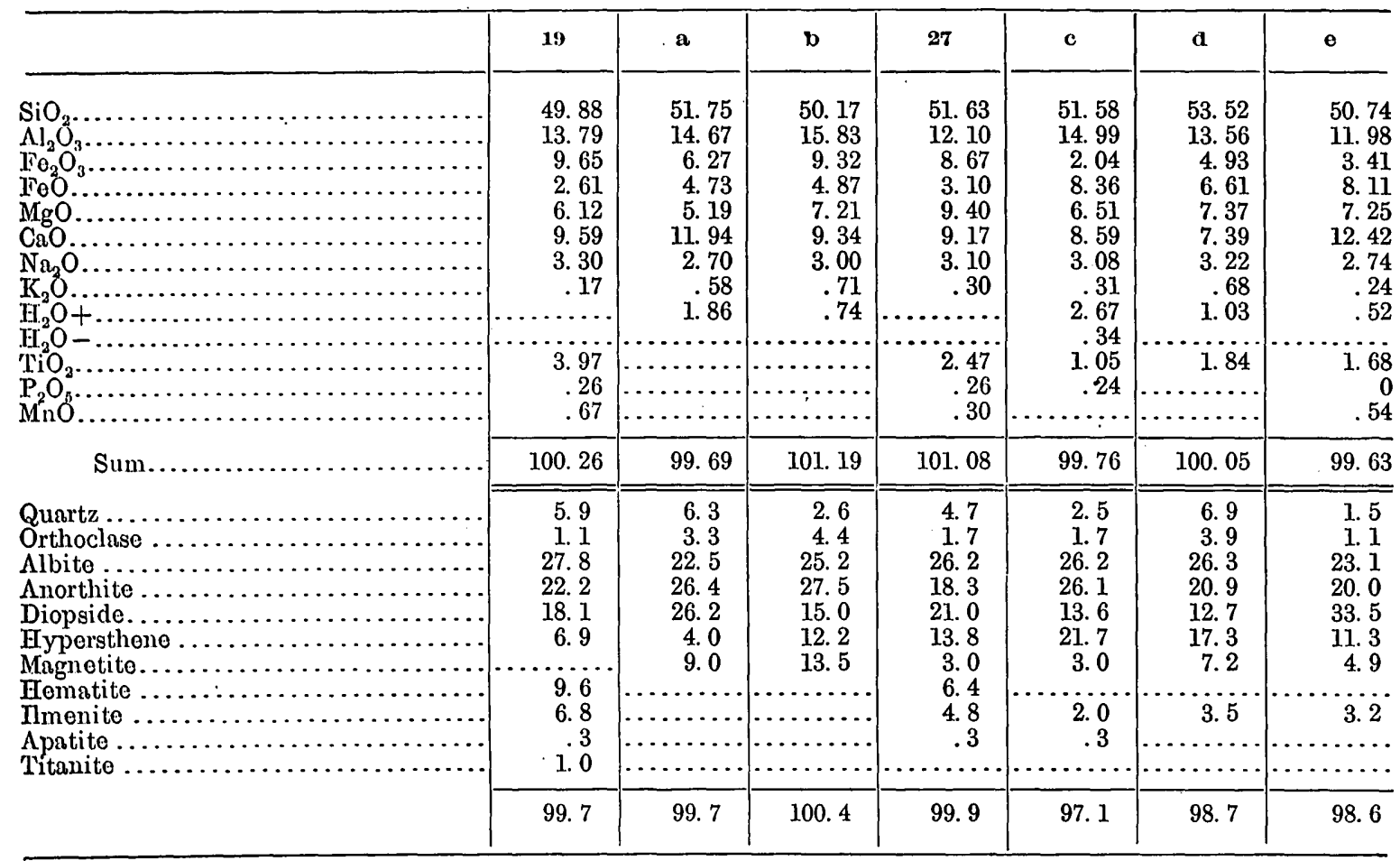

19. Basalt (Lyons), ornose, III.(4)5.3'.5. Koolau Mountains, Oahu.

a. Olivine-diabase (Cohen), auvergnose. North Kimberley, Griqualand, West South Africa.

b. Diabaso porphyrite (Cohen), auvergnose. Pfandstall, Colesberg, Cape Colony, South Africa.

27. Traplike basalt (Lyons), ornose, III.(4)5.3.5. Waianae Mountains, Oahu.

c. Diabase (Melville), ornose. Mitchel Canyon, Mount Diablo, Cal.

d. Basalt obsidian (Streng), ornose. Londorf, Vogelsberg, Hesse, Germany.

o. Basalt obsidian (Cohen), ornose. Lava of 1867, Ninafou, Tonga Islands. 
Analogues of Hawaiian lavas-Continued.

IX.

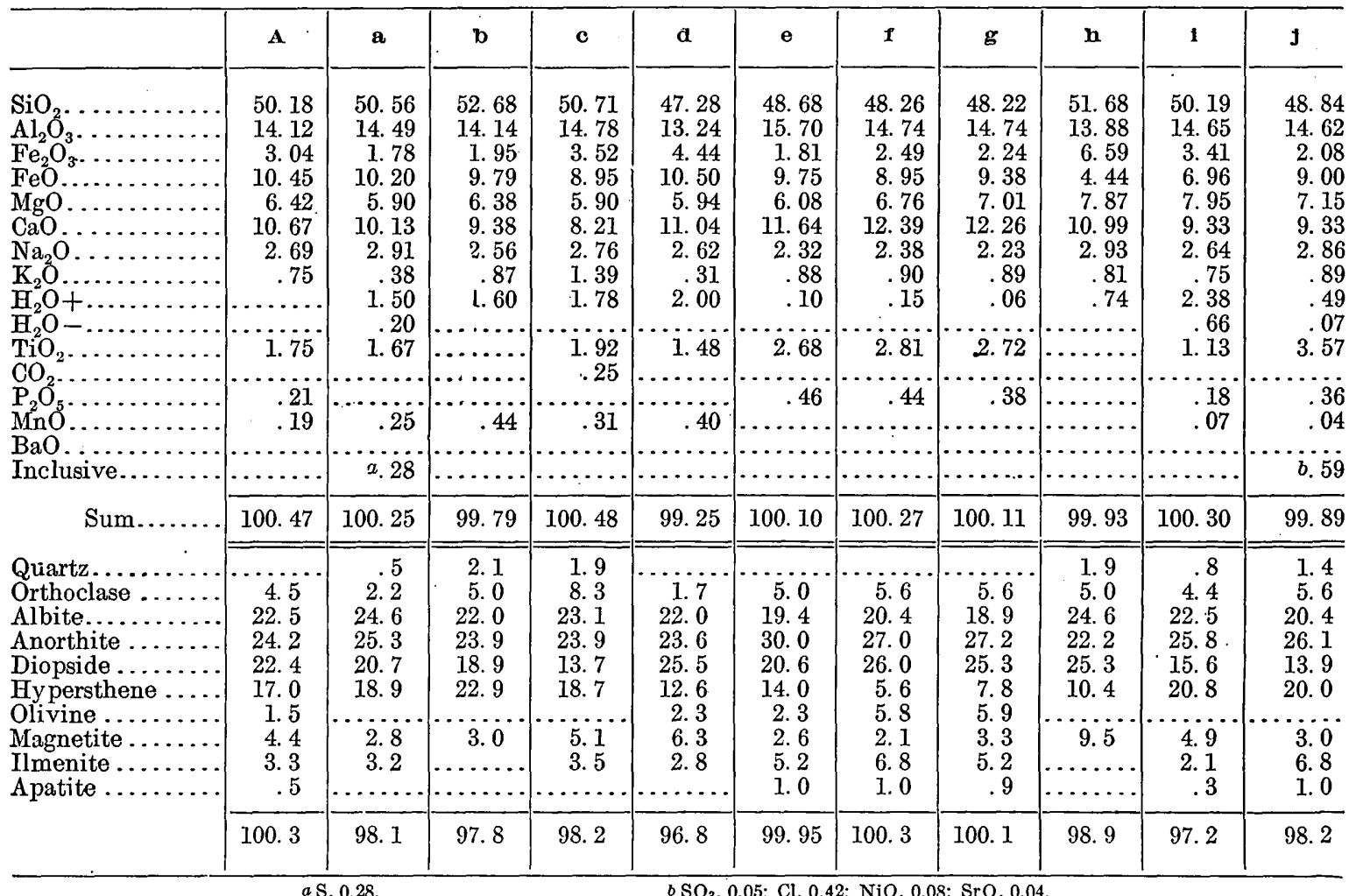

A. Average of nine analyses of basalt, Halemaumau, Kilauea. Camptonose-auvergnose, III.5.(3)4.4'.

a. Basalt (Diller), auvergnose. Cedar Creek, near Ophir, Oreg.

b. Dolerite (Hawes), auvergnose. Mount Holyoke, Mass.

c. Diabase (Teall), camptonose. Whin Sill, Durham, England.

d. Basalt (T'eall), auvergnose. Cape Flora, Franz Josef Land.

e. Basalt bomb (Lacroix), auvergnose, III.5.4.4-5. Reunion Island.

f. Basalt (Lacroix), auvergnose, III.5.'4.4-5. Lava of 1863, Piton de la Fournaise, Reunion Island.

g. Basalt (Lacroix), auvergnose, III.5.'4.4-5. Average of eight analyses, Piton de la Fournaise, Reunion Island.

h. Olivine diabase (Cohen), camptonose. Colesburg, Cape Colony, South Africa.

i. Basalt (Lewis), auvergnose, III.5.(3)4.4'. Hartshorn's quarry, Springfield, N. J.

j. Feldspar basalt (Washington), auvergnose, III.5.4.4. Monte Ponente, island of Linosa. 
Analogues of Hawaiian lavas-Continued.

$\mathbf{x}$.

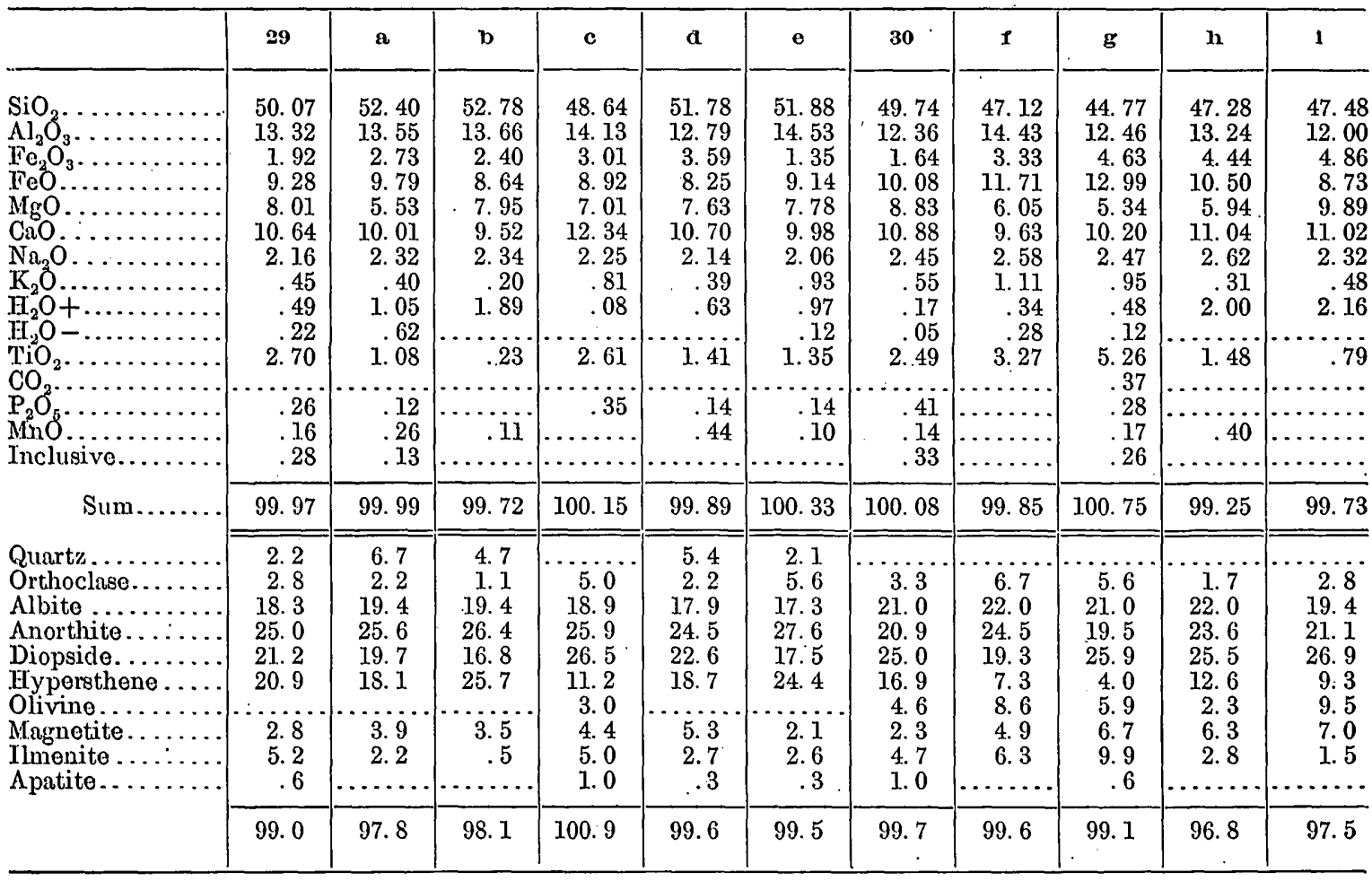

29. Basalt (Day), auvergnose, III.5.4.4-5. Flow of 1894(?), Kilauea.

a. Olivine basalt (Hobbs), koghose-auvergnose, III.(4)5.4.4-5. Pine Hill, South Britain, Conn.

b. Epidiorite (Harrison), auvergnose. Urinambo, Barama River, British Guiana.

c. Basalt (Lacroix), auvergnose, III.5.'4.4-5. Plaine des Osmondes, Reunion Island

d. Dolerite (Hawes), koghose-auvergnose, III.(4)5.4.4-5. West Rock, New Haven, Conn.

e. Basaltic diabase (Lewis), auvergnose, III.5.4.4-5. Weehawken, N. J.

30. Basalt (Day and Shepherd), ornose-camptonose, III.5.3(4).4(5). Dipped from lava basin, Halemaumau, Kilauea.

f. Diabase (Washington), camptonose. Rockport, Cape Ann, Essex County,.Mass.

g. Gabbro (Kemp), camptonose. Lincoln Pond, Essex County, N. Y.

h. Basalt (Teall), auvergnose. Cape Flora, Franz Josef Land.

i. Issite (Duparc and Pamphil), auvergnose, III.5.4.4-5. Kamenouchki, southern Ural Mountains, Russia. 
Analogues of Hawaiian lavas-Continued.

XI.

\begin{tabular}{|c|c|c|c|c|c|c|c|c|c|}
\hline & 31 & a & b & c & 35 & d & e & $\mathbf{r}$ & $\mathbf{g}$ \\
\hline 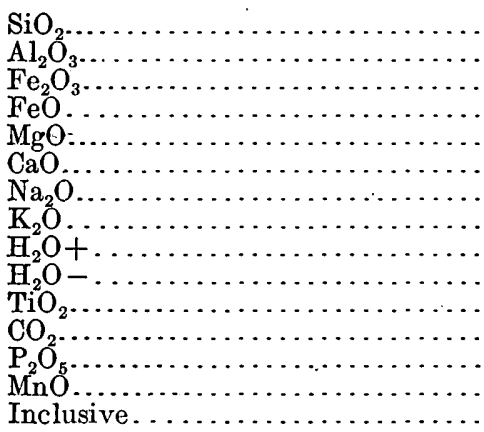 & $\begin{array}{r}48.99 \\
13.73 \\
1.60 \\
10.46 \\
13.53 \\
7.34 \\
1.62 \\
.27 \\
.27 \\
.10 \\
1.73 \\
.24 \\
.13 \\
.20 \\
.17\end{array}$ & $\begin{array}{r}50.88 \\
13.17 \\
1.11 \\
9.66 \\
13.05 \\
10.19 \\
1.17 \\
.31 \\
.14 \\
\ldots\end{array}$ & $\begin{array}{r}48.35 \\
15.40 \\
4.04 \\
4.63 \\
11.61 \\
10.38 \\
1.87 \\
.35 \\
3.60 \\
\cdots . .\end{array}$ & $\begin{array}{r}45.69 \\
13.92 \\
3.06 \\
9.02 \\
11.45 \\
10.49 \\
1.76 \\
.11 \\
.79 \\
.78 \\
2.00 \\
.77 \\
.81 \\
\ldots . . .\end{array}$ & $\begin{array}{r}45.48 \\
11.87 \\
1.98 \\
9.87 \\
13.28 \\
10.97 \\
2.21 \\
.77 \\
.74 \\
.23 \\
1.90 \\
.25 \\
.04 \\
.19\end{array}$ & $\begin{array}{r}44.06 \\
15.10 \\
5.23 \\
7.93 \\
9.84 \\
12.56 \\
2.20 \\
.93 \\
.30\end{array}$ & $\begin{array}{r}44.75 \\
13.22 \\
1.20 \\
10.50 \\
10.85 \\
11.50 \\
1.95 \\
1.27 \\
1.62 \\
3.45 \\
.38 \\
. .3 \%\end{array}$ & $\begin{array}{r}45.71 \\
1.0 .80 \\
4.43 \\
9.35 \\
13.75 \\
10.48 \\
1.58 \\
.85 \\
.97 \\
1.83 \\
1.83 \\
.11 \\
.17\end{array}$ & $\begin{array}{r}44.71 \\
11.24 \\
5.48 \\
8.21 \\
14.32 \\
10.22 \\
2.50 \\
1.01 \\
.21 \\
2.00 \\
2 . \\
.37 \\
. . .\end{array}$ \\
\hline Sum. & 100.38 & 99.67 & 100.31 & 100.65 & 99.94 & 100.84 & 100.71 & 100.13 & 100.27 \\
\hline 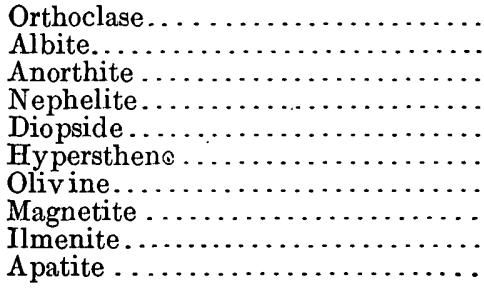 & $\begin{array}{r}5.1 \\
36.8 \\
7.2 \\
2.3 \\
3.2 \\
.3\end{array}$ & \begin{tabular}{r}
1.7 \\
10.0 \\
29.7 \\
\hdashline 16.9 \\
35.4 \\
4.3 \\
1.6 \\
$\ldots .$.
\end{tabular} & $\begin{array}{r}2.2 \\
15.7 \\
32.5 \\
15.0 \\
21.1 \\
4.3 \\
5.8 \\
\cdots \cdots\end{array}$ & $\begin{array}{r}13.5 \\
21.9 \\
6.9 \\
4.4 \\
3.8 \\
2.0\end{array}$ & $\begin{array}{r}4.5 \\
12.8 \\
20.6 \\
2.9 \\
26.4 \\
3.3 .5 \\
24.5 \\
3.0 \\
3.7 \\
.5\end{array}$ & $\begin{array}{r}5.6 \\
11.0 \\
28.6 \\
4.0 \\
24.0\end{array}$ & $\begin{array}{r}7.8 \\
10.5 \\
23.4 \\
3.4 \\
24.9 \\
\cdots \cdots \\
20.0 \\
1.9 \\
6.5 \\
1.0\end{array}$ & $\begin{array}{r}26.2 \\
6.3 \\
18.3 \\
6.5 \\
3.5\end{array}$ & \begin{tabular}{r}
6.1 \\
13.4 \\
16.4 \\
4.2 \\
24.9 \\
\hdashline 22.9 \\
7.9 \\
3.8 \\
1.0
\end{tabular} \\
\hline & 99.4 & 99.6 & 96.6 & 97.8 & 98.9 & 100.5 & 99.4 & 98.9 & 100.5 \\
\hline
\end{tabular}

31. Basalt (Cross), auvergnose, III.5.4.4-5. Flow, Olokele Canyon, Kauai.

a. Olivine-hypersthene diabase (Campbell and Brown), auvergnose. The Twins, Culpeper County, Va.

b. Greenstone (diabase) (Williams), auvergnose. Upper Quinnesec Falls, Menominee River, Wis.

c. Basalt (Schottler), auvergnose, III.5.4.4-5. Wartfeld, near Grüningen, Giessen, Hesse-Darmstadt, Germany. 35. Basalt (Cross), camptonose-auvergnose, $\mathrm{III}^{\prime} .5^{\prime}$.(3)4.4-5. Flow, Olokele Canyon, Kauai.

d. Basalt (v. John), auvergnose. Punta Delgada, San Miguel, Azores.

e. Olivine basalt (Lacroix), camptonose-auvergnose, III.5'.(3)4.4-5. Papenoo Valley, Tahiti.

f. Hornblende picrite (Iddings), auvergnose, III'.5.4'.5. Conical Peak, Crazy Mountains, Mont.

g. Basalt (Reinisch), limburgose-camptonose, III(IV).5(6).3.4. Heard Island, Antarctic region. 
Analogues of Hawaiian lavas-Continued.

XII.

\begin{tabular}{|c|c|c|c|c|c|c|c|c|c|}
\hline & 36 & $\mathbf{a}$ & b & 37 & 40 & c & d & $\mathbf{e}$ & 1 \\
\hline 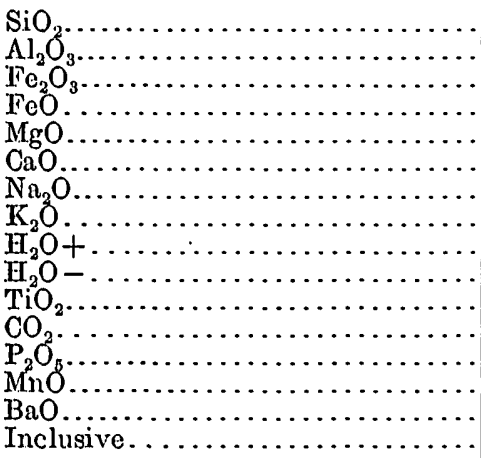 & 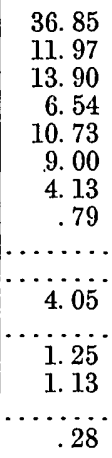 & $\begin{array}{r}43.76 \\
11.58 \\
4.39 \\
7.57 \\
12.97 \\
9.64 \\
3.03 \\
1.84 \\
.47 \\
3.41 \\
.38 \\
.45 \\
\ldots . . .\end{array}$ & $\begin{array}{r}44.78 \\
12.76 \\
5.42 \\
8.34 \\
10.17 \\
10.23 \\
3.56 \\
1.81 \\
1.42 \\
\ldots .25 \\
.93 \\
.92 \\
\ldots . .\end{array}$ & $\begin{array}{r}35.86 \\
12.10 \\
7.82 \\
8.09 \\
9.72 \\
12.08 \\
6.23 \\
1.93 \\
\ldots \ldots \\
2.90 \\
1.08 \\
.39 \\
1.92\end{array}$ & $\begin{array}{r}36.34 \\
10.14 \\
6.53 \\
1.0 .66 \\
10.68 \\
13.10 \\
4.54 \\
1.78 \\
1.00 \\
1.00 \\
2.87 \\
.15 \\
1.02 \\
.20 \\
\ldots .04\end{array}$ & 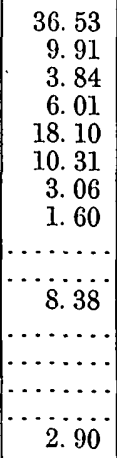 & $\begin{array}{r}37.98 \\
9.30 \\
5.96 \\
5.86 \\
17.13 \\
10.38 \\
3.50 \\
2.03 \\
2.74 \\
\ldots \ldots . \\
2.02 \\
.36 \\
.31 \\
\ldots . . \\
\ldots . .3 \\
2.49\end{array}$ & $\begin{array}{r}39.47 \\
11.26 \\
8.74 \\
4.98 \\
14.33 \\
12.08 \\
5.04 \\
1.86 \\
.63 \\
\ldots \ldots . \\
1.56 \\
\ldots \ldots . . \\
\ldots \ldots \\
\ldots \ldots . . \\
\ldots \ldots \\
\ldots \ldots\end{array}$ & $\begin{array}{r}37.96 \\
10.14 \\
3.69 \\
7.59 \\
14.69 \\
16.28 \\
2.18 \\
.69 \\
1.82 \\
.39 \\
2.93 \\
. .19 \\
1.13 \\
.22 \\
.06 \\
.33\end{array}$ \\
\hline 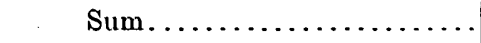 & 100.62 & 99.78 & 100.59 & 100. 12 & 100.05 & 100.64 & 100.15 & 100.94 & 100.13 \\
\hline 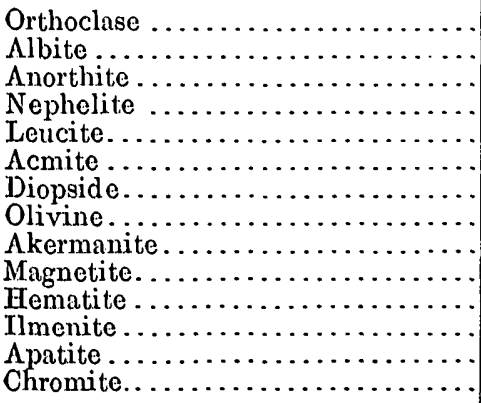 & $\begin{array}{c}19.4 \\
12.5 \\
\ldots \ldots \\
13.0 \\
5.0 \\
7.7 \\
2.7 \\
\ldots \ldots \ldots\end{array}$ & $\begin{array}{r}11.1 \\
10.5 \\
12.5 \\
8.2 \\
\ldots \\
23.7 \\
18.3 \\
6.5 \\
6.5 \\
6.0 \\
6.5 \\
1.0\end{array}$ & $\begin{array}{c}25.6 \\
17.3 \\
\cdots \ldots .9 \\
7.9 \\
\cdots \ldots \\
2.5 \\
2.0\end{array}$ & $\begin{array}{c}\ldots \ldots \\
\cdots \ldots . \\
\cdots \ldots . . \\
28.1 \\
8.7 \\
.5 \\
13.4 \\
16.3 \\
12.2 \\
11.1 \\
\cdots \ldots \\
5.5 \\
2.7 \\
\ldots \ldots\end{array}$ & $\begin{array}{c}\ldots .7 \\
1.7 \\
21.0 \\
8.3 \\
\ldots \ldots . . \\
17.4 \\
20.2 \\
12.0 \\
9.5 \\
\ldots \ldots \\
5.5 \\
2.4 \\
\ldots \ldots\end{array}$ & $\begin{array}{c}\ldots .6 \\
8.6 \\
13.9 \\
7.4 \\
\ldots \ldots \ldots \\
22.0 \\
24.6 \\
a 5.6 \\
\cdots \ldots \ldots \\
3.8 \\
9.9 \\
\cdots \ldots \\
4.3\end{array}$ & $\begin{array}{c}\cdots 21.6 \\
25.6 \\
4.9 \\
8.6 \\
\cdots . .9 \\
3.9 \\
.7 \\
\ldots \ldots\end{array}$ & $\begin{array}{c}\ldots 2.7 \\
17.7 \\
8.1 \\
12.5 \\
\ldots \ldots \ldots \\
3.1 \\
2.2 \\
\ldots \ldots \ldots\end{array}$ & $\begin{array}{r}\cdots \\
18.6 \\
9.9 \\
3.1 \\
\cdots \\
13.5 \\
26.1 \\
13.8 \\
5.3 \\
\ldots \ldots \\
4.4 \\
2.6 \\
\ldots \ldots\end{array}$ \\
\hline & 100.4 & 98.3 & 98.5 & 98.5 & 98.0 & 100. 1 & 94.3 & 100.5 & 97.3 \\
\hline
\end{tabular}

a Perofskite.

36. Basaltic scoria (Lyons), monchiquose-(unnamed), III(IV).6'.2(3).(4)5. Cinder cone, Punahou, near Honolulu, Oahu.

a. Nephelite basalt (Klautsch), monchiquose-limburgose, III'.6.(2)3.4. Lava of 1905-6, Matavuna volcano, Savaii, Samoan Islands.

b. Basalt (Beyschlag), limburgose. Hünenberg, Blatt Melsungen, Prussia.

37. Black sand (Lyons), (unnamed)-casselose, (III)IV.2./4.2(.3).2'. Recent lapilli, Punahou, near Honolulu, Oahu.

40. Nephelite-melilite basalt (Cross), uvaldose-casselose, 'IV.2.(3)4.2(3).2(3). Moiliili, near Honolulu, Oahu.

c. Melilite basalt (Grubenmann), uvaldose. Wartenberg, Hegau, Baden.

d. Melilite-nephelite basalt (Rinne), uvaldose. Hohenberg, Bühne, Westphalia.

e. Nephelite basalt (Stock), uvaldose. Schafberg Plateau, Lobauerberg, Saxony.

f. Nephelite-melilite basalt (Cross), casselose. Near Uvalde, Uvalde County, Tex. 
Analogues of Hawaiian lavas-Continued.

xirr.

\begin{tabular}{|c|c|c|c|c|c|c|c|}
\hline & 38 & $\mathbf{a}$ & b & 39 & c & a & e \\
\hline 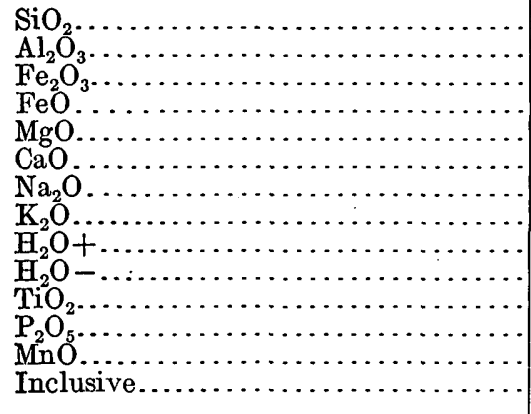 & $\begin{array}{r}48.57 \\
10.51 \\
2.19 \\
9.45 \\
17.53 \\
8.06 \\
1.59 \\
.34 \\
.37 \\
.10 \\
1.48 \\
.19 \\
.16 \\
.18\end{array}$ & \begin{tabular}{r}
45.71 \\
10.80 \\
4.43 \\
9.35 \\
13.75 \\
10.48 \\
1.58 \\
.85 \\
.97 \\
\hdashline 1.83 \\
.11 \\
.17
\end{tabular} & $\begin{array}{r}49.02 \\
10.14 \\
1.54 \\
10.46 \\
17.25 \\
8.29 \\
1.59 \\
.40 \\
.75 \\
\ldots .99 \\
.11 \\
.16\end{array}$ & $\begin{array}{r}42.99 \\
10.21 \\
3.01 \\
10.28 \\
14.61 \\
12.54 \\
1.40 \\
.52 \\
1.10 \\
.82 \\
2.52 \\
.29 \\
.17 \\
.12\end{array}$ & \begin{tabular}{r|}
48.29 \\
10.00 \\
2.93 \\
5.46 \\
17.22 \\
11.80 \\
2.78 \\
.45 \\
1.95 \\
\hdashline.... \\
\hdashline \\
$\cdots$
\end{tabular} & $\begin{array}{r}41.03 \\
11.07 \\
4.65 \\
7.05 \\
15.75 \\
10.59 \\
1.71 \\
.94 \\
1.36 \\
2.85 \\
2.43 \\
.41 \\
\ldots . . .\end{array}$ & $\begin{array}{r}41.50 \\
12.31 \\
5.20 \\
8.46 \\
11.29 \\
14.05 \\
2.06 \\
.48 \\
.50 \\
4.78 \\
.06 \\
\ldots \ldots . .\end{array}$ \\
\hline Sum.. & 100.72 & 100.13 & 100.70 & 100.58 & 100.88 & 99.84 & 100.69 \\
\hline 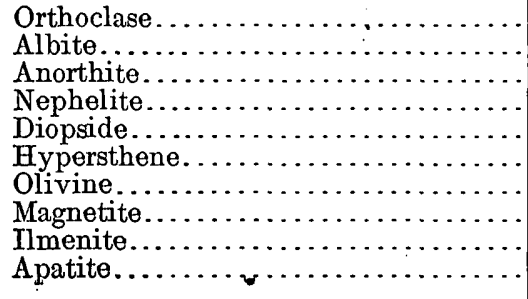 & $\begin{array}{r}2.2 \\
13.6 \\
20.3 \\
31.9 \\
14.9 \\
23.9 \\
18.7 \\
3.3 \\
2.9 \\
.4\end{array}$ & $\begin{array}{r}5.0 \\
13.1 \\
20.0 \\
26.2 \\
6.3 \\
18.3 \\
6.5 \\
3.5 \\
\cdots \cdots\end{array}$ & $\begin{array}{r}2.2 \\
13.6 \\
19.2 \\
37.0 \\
17.0 \\
22.9 \\
20.7 \\
2.1 \\
2.0 \\
.3\end{array}$ & $\begin{array}{r}2.8 \\
6.3 \\
20.0 \\
3.1 \\
32.3 \\
3.3 \\
24.2 \\
4.4 \\
4.7 \\
.7\end{array}$ & $\begin{array}{r}2.8 \\
13.1 \\
13.3 \\
5.7 \\
35.7 \\
24.1 \\
4.2 \\
\cdots\end{array}$ & $\begin{array}{r}5.6 \\
6.3 \\
20.0 \\
4.3 \\
23.6\end{array}$ & 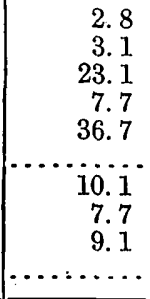 \\
\hline & 100.2 & 98.9 & 100.0 & 98.5 & 98.9 & 95.8 & 100.3 \\
\hline
\end{tabular}

38. Ultrafemic olivine basalt (Daly), palisadose-hilose, (III)IV.1(2).2.1(2).2. Flow of 1852, Mauna Loa, Hawaii. a. Hornblende picrite (Iddings), auvergnose, Conical Peak, Crazy Mountains, Mont.

b. Olivine diabase (Lewis), palisadose, Englewood Cliffs, N. J.

39. Picritic basalt (Cross), rossweinose-uvaldose, 'IV(1)2.'32.2. Summit of Mount Haleakala, Maui.

c. Gabbro (Sachsse and Becker), rossweinose. Etzdorf, Rosswein, Saxony.

d. Trachydolerite (Bücking), auvergnose, III(IV).5(6).4.4-5. Platzer Kuppe, Rhöngebirge, Germany.

e. Essexitic gabbro (Lacroix), unnamed subrang, (III)IV.2.2.2.2. Papenoo Valley, Tahiti. 
Analogues of Hawaiian lavas-Continued.

XIV.

\begin{tabular}{|c|c|c|c|c|c|c|c|c|c|c|}
\hline & $\mathbf{4 1}$ & $\mathbf{a}$ & $\mathbf{b}$ & $\mathbf{c}$ & 42 & a & $\mathbf{4 3}$ & $\mathbf{e}$ & $\mathbf{I}$ & $\mathbf{g}$ \\
\hline 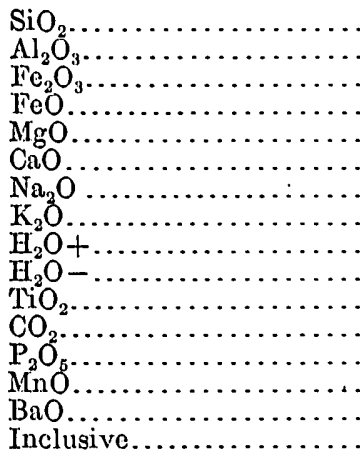 & $\begin{array}{r}47.25 \\
9.07 \\
1.45 \\
10.41 \\
19.96 \\
7.88 \\
1.38 \\
.35 \\
.04 \\
.08 \\
1.61 \\
\ldots .21 \\
.21 \\
.13 \\
.21\end{array}$ & $\begin{array}{r}47.75 \\
10.56 \\
.74 \\
8.34 \\
19.09 \\
9.62 \\
1.32 \\
.12 \\
2.06 \\
.05 \\
.37 \\
\ldots .03 \\
.10 \\
\ldots .31\end{array}$ & $\begin{array}{r}39.07 \\
9.95 \\
5.15 \\
10.37 \\
19.19 \\
6.29 \\
.97 \\
.19 \\
7.65 \\
\ldots .68 \\
.09 \\
.13 \\
.17 \\
\ldots . .6 \\
.05\end{array}$ & 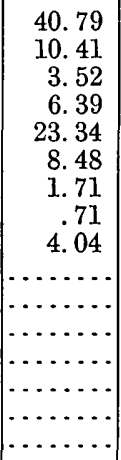 & $\begin{array}{r}46.59 \\
7.69 \\
2.20 \\
10.46 \\
21.79 \\
7.41 \\
1.33 \\
.28 \\
.37 \\
.04 \\
1.83 \\
\ldots .11 \\
.18 \\
. .25\end{array}$ & 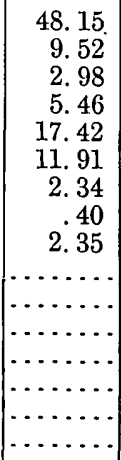 & $\begin{array}{r}37.50 \\
9.12 \\
5.59 \\
8.81 \\
13.72 \\
13.85 \\
2.69 \\
.63 \\
2.35 \\
1.05 \\
3.21 \\
.27 \\
.90 \\
.15 \\
.07 \\
.28\end{array}$ & $\begin{array}{r}39.92 \\
8.60 \\
4.40 \\
8.00 \\
20.17 \\
10.68 \\
1.91 \\
1.03 \\
1.45 \\
.43 \\
2.70 \\
\ldots . .5 \\
.51 \\
.24 \\
.06 \\
.35\end{array}$ & 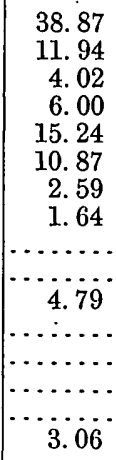 & $\begin{array}{r}39.16 \\
10.06 \\
6.54 \\
7.71 \\
13.74 \\
15.30 \\
2.38 \\
1.46 \\
1.55 \\
\ldots . .5 \\
1.52 \\
.58 \\
.75 \\
.11 \\
\ldots \ldots . \\
\ldots \ldots\end{array}$ \\
\hline Sum.............. & 100.03 & 100.46 & 99.95 & 99.39 & 100.53 & 100.53 & 100.19 & 100.45 & 99.02 & 100.86 \\
\hline 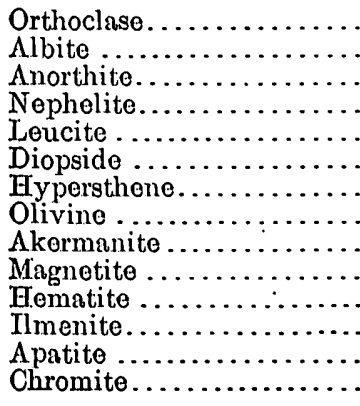 & $\begin{array}{l}16.2 \\
19.5 \\
27.4 \\
2.1\end{array}$ & $\begin{array}{c}19.8 \\
16.3 \\
25.8 \\
\ldots \ldots \\
\ldots 9\end{array}$ & $\begin{array}{r}6.6 \\
9.7 \\
34.3 \\
7.7\end{array}$ & 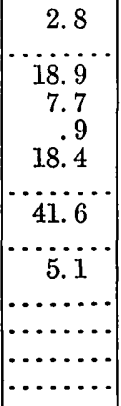 & $\begin{array}{c}1.7 \\
11.0 \\
14.7 \\
\cdots \ldots . . \\
\cdots \cdots \\
16.8 \\
17.9 \\
30.8\end{array}$ & $\begin{array}{c}2.2 \\
14.7 \\
14.2 \\
2.8 \\
\cdots \\
35.4 \\
\cdots \cdots \\
24.5\end{array}$ & $\begin{array}{r}11.1 \\
12.2 \\
2.6 \\
31.0 \\
\cdots 18.6 \\
3.9 \\
8.1 \\
\cdots \ldots .1 \\
6.1 \\
2.0 \\
\ldots \ldots\end{array}$ & $\begin{array}{c}12.0 \\
8.5 \\
4.9 \\
24.6 \\
\cdots 32.1 \\
32.4 \\
6.3 \\
\cdots \ldots \\
5.1 \\
1.2 \\
\ldots \ldots \ldots\end{array}$ & \begin{tabular}{c}
16.1 \\
11.9 \\
7.4 \\
25.0 \\
\hdashline 18.5 \\
2.0 \\
1.2 \\
3.2 \\
8.9 \\
$\ldots . .5$ \\
4.5
\end{tabular} & $\begin{array}{r}12.2 \\
11.1 \\
7.0 \\
16.7 \\
23.3 \\
13.7 \\
9.5 \\
\cdots \\
2.8 \\
1.8 \\
\ldots . .8\end{array}$ \\
\hline & 99.5 & 98.0 & 91.7 & 95.4 & 100.2 & 98.2 & 95.6 & 97.1 & 98.7 & 98.1 \\
\hline
\end{tabular}

41. Picritic basalt (Cross), Rossweinose-wehrlose, 'IV.1'.3.1(2).2. Flow of 1840, Nanawale, Puna, Hawaii.

a. Diabase? (Turner), rossweinose. Cathay Hill, Mariposa County, Cal.

b. Picrite. Sechshelden, Nassau.

c. Picrite-porphyrite (Tschermak), custerose. Gümbelberg, Neutitschein, Moravia.

42. Porphyritic gabbro (Daly), rossweinose-wehrlose, IV.1(2).3.1(2).2. Uwekahuna laccolith, Kilauea, Hawaii.

d. Gabbro (Sachsse and Becker), rossweinose. Etzdorf, Rosswein, Saxony.

43. Nephelite-melilite basalt (Cross), uvaldose, IV.2.3.2.2. Kilauea Landing, north coast of Kauai.

e. Nephelite basalt (Cross). Black Mountain, Uvalde County, Tex.

f. Melilite basalt (Grubenmann). Hohenhöwen, Hegau, Baden.

g. Nephelite basalt (Leppla and Schwager). Oberleinleiter, Franken Jura, Bavaria. 
General facts of distribution.-The foregoing table presents clearly many features which it is almost superfluous to repeat in words. But it may be well to summarize some of the more important facts. The analogues of Hawaiian magmas. are widely distributed over the world, 36 occurring in various countries of Europe, 32 in North America, 10 in Africa or the adjacent island of Reunion, 11 in other islands of the Pacific, and a few others in scattered localities. Continental Asia has no representative and South America only one, but this is surely due to the degree of similarity sought for and to meager material for comparison. The broad facts are shown in the table given below. The roman numerals at the head of the columns refer to the corresponding divisions of the preceding table.

Distribution of analogous rocks.

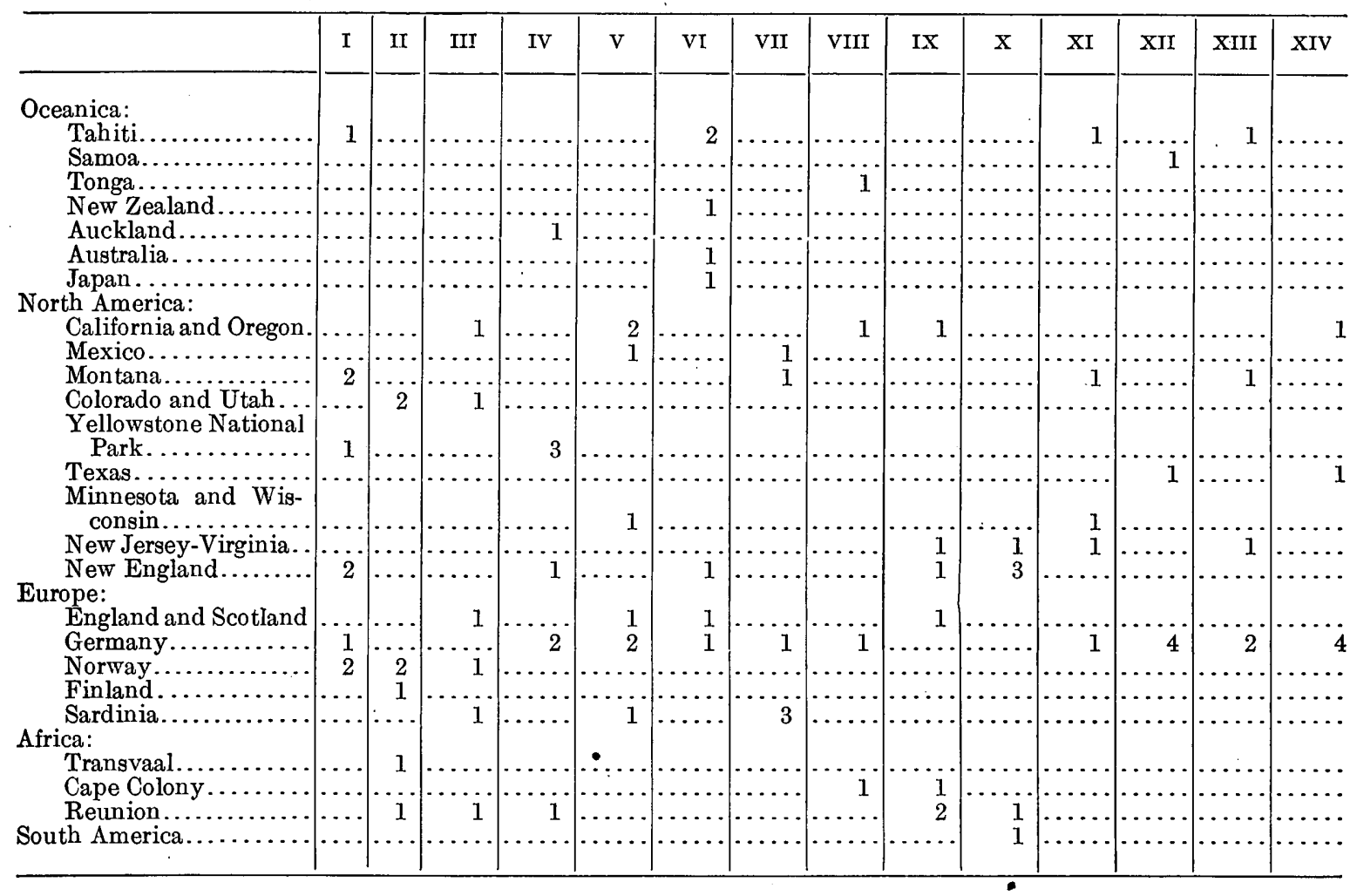

Analogous rocks of Oceanica.-It would seem natural to find that other island groups of the Pacific contained lavas very similar to those of Hawaii. But such similarity is not very clearly shown by the meager chemical data at hand for some of the groups most nearly resembling Hawaii in general character. It is highly probable, however, that future work will disclose strong analogies between Hawaii and several of the groups of Oceanica.

The rocks of Tahiti, recently described by Lacroix, ${ }^{1}$ with analyses by Pisani and Boiteau, bear the closest analogy to those of Hawaii. The Tahiti analogues come mostly from the deepcut valley of Papenoo and embrace both lavas and granular intrusives. Of two Papenoo basalts, one is an analogue of an olivine-rich basalt of Olokele Canyon, Kauai (No. 35), and the other of a basalt from the caldera walls of Kilauea (No. 11). Of the granular intrusives of Tahiti, a rock called "gabbro néphélinique" or theralith by Lacroix is like another basalt of the wall of Kilauea (No. 9), and a "gabbro essexitique" corresponds to the summit picritic basalt of Haleakala (No. 39). Although the "gabbro essexitique" has no lenad, according to Lacroix, the norm contains 7.7 per cent of nephelite, which is more than twice that in the picritic basalt of Haleakala. 
There is also a lava of Tahiti, called phonolite by Lacroix, although it contains but little nephelite, which is very near the trachytic obsidian of Puu Waawa in composition, as the French petrographer has pointed out. ${ }^{1}$ Lacroix also describes tinguaite (miaskose), syenite (borolanose), nephelite syenite, nephelite monzonite, camptonite, and hauynophyre (all these four belonging to essexose), microgabbro (camptonose), and picrite (custerose), in addition to those forms which are more particularly compared with rocks of Hawaii. The prevalent resemblance to rocks commonly referred to the alkalic series is recognized by Lacroix.

The significance of this similarity between the rocks of Tahiti and Hawaii is emphasized by the fact that the more direct analogues include highly salic, intermediate, and strongly femic magmas, suggesting similar lines of differentiation at the two centers.

The lavas of the Samoan Islands, formerly referred to in general terms as basaltic, may very likely be found to possess as great a variety as is exhibited by those of Hawaii. How great a similarity exists between these lava series remains to be determined, but Weber ${ }^{2}$ has shown the existence in the several islands of the Samoan group of common plagioclase-olivine basalt, limburgite, several nephelite-bearing varieties included under trachydolerite, phonolite, and alkali trachyte. Unfortunately the analyses given by Weber (Dr. Hobein, analyst) are too incomplete and otherwise inadequate to furnish a basis for satisfactory chemical study. It seems plain that in a general way the Samoan and Hawaiian rock series show many interesting points of similarity.

The single rock of Samoa shown by analysis to be a close analogue of a Hawaiian type is the lava of 1905-6 from the great volcano of Matavuna, on Savaii, described by Klautsch. ${ }^{3}$ As shown in the table, this lava approximates in composition a scoria from a small recent cinder cone at Punahou, near Honolulu, and is quite different from the lavas of the large Hawaiian volcanoes. In contrast to this relation of the Matavuna lava, it appears that the lava of 1867 in the Tonga group is very near one of the old basalts of Oahu.

Comparison with rocks of Reunion.-The most striking analogy noted is between the lavas of Hawaii and those of the island of Reunion, recently described by Lacroix, ${ }^{4}$ who recognizes the similarity. It appears that the lavas of the active center of the Piton de la Fournaise bear a close resemblance both in range of variation and in average composition to those of Kilauea. Lacroix presents analyses of these recent lavas, most of them belonging to auvergnose, and has calculated their average. This average and the analyses of two individual rocks are compared in Division IX of the table (p. 72) with the average of nine analyses from Halemaumau. This mean of the Reunion rocks is still nearer, however, to the two lavas of Halemaumau given in Division X.

Aside from this analogy of recent lavas it is of particular interest to find that among the older lavas on the flanks of the extinct and dissected Piton de Neiges, Reunion, are several close analogues of Hawaiian types not found at Kilauea. One of these corresponds to the kohalaite (Division II), another to the trachydolerite of Daly from Mauna Kea (Division III), and a third to the trachydolerite from Haleakala (Division IV). A feldspathic picrite lava alternates with trachydolerite in some places, further emphasizing the relation to conditions in Haleakala.

European analogues.-Among the countries of Europe, Germany has the greatest number of rocks resembling those of Hawaii in composition. These rocks come from widely separated localities, but a considerable number of them occur in Hesse, Nassau, and the Rhoen Mountains. The German rocks cited are analogues of several of the more salic lavas and especially of the ultrabasic lavas of Divisions XII, XIII, and XIV of the table. Rather singularly, the modern lavas of Kilauea and the normal basalts of Kauai have no discovered close analogues among German rocks, though such analogues doubtless exist.

The extremely salic lavas of Divisions I, II, and III find counterparts in Norway among the alkalic rocks of the Christiania region, but here the detected analogy ends. The intermediate and basic rocks of Hawaii seem to have no equivalents in Norway. Comment will be made on this point later on.

\footnotetext{
1 Op. cit., p. 124

8 K. preuss. geol. Landesanstalt Jahrb., 1907, p. 174.

2 K. bayer. Akad. Wiss. math.-phys. Klassa A bh., vol. 24, pt. 2, pp. 287-310, 1909.

Compnt. Rend., vol. 155, pp. 538-54, 1913.
} 
A notable number of Hawaiian types, including older lavas of Kilauea and three of the more alkalic rocks, find analogues in Sardinia.

No other district is particularly noteworthy on account of the number of its rocks standing in close relationship to those of Hawaii, but there are points of interest attaching to many of the analogies brought out in the table which will be emphasized in the theoretical discussion.

THEORETICAL BEARINGS OF DATA PRESENTED.

geOgRaPhic Distinction BETWEen ATLANTIC AND PACIFIC REgIONS.

It is perhaps unnecessary to register any further protest against the use of the terms Atlantic and Pacific as expressing the distribution of the so-called Alkalic and Calcic branches or Sippen of igneous rocks. But a brief résumé of the situation seems appropriate in this place.

The original proposition by Harker ${ }^{1}$ was to distinguish "an Atlantic and a Pacific facies of igneous rocks, corresponding with distinct phases in crust movements of a large order." But he later made the more definite generalization that these "branches" were geographically restricted in their distribution in the "Atlantic and Pacific regions," which he outlined."

The work of Weber, Lacroix, Daly, and myself, together with scattered evidence from many quarters, demonstrates that the Pacific island groups are characterized by alkalic rather than by calcic magmas. On the shores of the Pacific are many occurrences of alkalic rocks. It is therefore not appropriate to use the terms Atlantic and Pacific for petrographic regions supposed to be characterized by chemically different magmas.

The primary idea of Harker and Becke was to make a petrogenetic generalization parallel to that of Suess as to the tectonic differences of the mountain ranges adjacent to the two oceanic basins. Whatever relation may exist between tectonic and petrographic provinces, its nature has not yet been established, and Harker ${ }^{3}$ has abandoned, tentatively at least, the use of the terms Atlantic and Pacific for the Alkalic and Calcic branches of igneous rocks.

\section{REFERENCE OF HAW.AIIAN LAVAS TO ALKaLIC OR CALCIC SERLES.}

With the data of chemical and mineral composition and association of Hawaiian volcanic rocks and the world-wide occurrence of analogous types before us, it remains to see whether these facts substantiate or refute the genetic and systematic generalizations as to the distinction between the Alkalic and Calcic series. The Hawaiian lavas have been generally considered by petrographers as true basalts - an assignment which refers them to the Calcic series. Rosenbusch ${ }^{4}$ cites one analysis of a lava of Kilauea (No. 23 of the table on p. 48) and one. of Mauna Loa (No. 32) as of true basalts. Harker ${ }^{5}$ considers that the trachyte of Puu Waawaa is not sufficient to throw discredit on the designation of the Hawaiian rocks and those of other Pacific island groups as assemblages of typical subalkalic (calcic) character.

Soda trachytes.-Of the two soda trachytes of Division I of the table of analogues, the rock of Puu Waawar (No. 2) must surely be considered a true alkali trachyte, in the Rosenbusch sense, as it contains no normative anorthite. But the rock of Lahaina (No. 1) has 3.61 per cent of normative anorthite, and as some of the soda is present in ægirite the mode of this rock must contain correspondingly more anorthite in its plagioclase. Were the same rule applied to the syenites as to the granites this trachyte would belong to the Calcic series. But it contains ægirite, and the names and associations of the analogous rocks show them to be currently considered as typically alkalic.

Kohalaite.-The kohalaite of Division II of the table has normative oligoclase $\left( \pm \mathrm{Ab}_{4} \mathrm{An}_{1}\right)$, Unfortunately, I do not know the mode of this rock, analyzed by Lyons and said to be a dense gray lava, and I have found no close analogue among surface rocks. As the table shows, its

1 Science Progress, vol. 6, p. 26, 1896.

2 Natural history of igneous rocks, pp. 93-100, London, 1909.

a British Assoc. Adv. Sci., Section C, Presidential Address, p. 4, Portsmouth, 1911.

4 Elemente der Gesteinslehre, 3d ed., p. 399, Stuttgart, 1910.

5 Op. cit., pp. 96-97. 
nearest relatives are leeuwfonteinite, nation minette, akerite, and augite syenite of well-known regions of markedly alkalic types. But the two monzonite porphyries, $d$ and $f$ of Division II, raise interesting questions for consideration.

The rock marked $f$ is the most highly alkalic type of the original Gilbert collection from the Henry Mountains, ${ }^{1}$ associated with intrusive types of quartz monzonite and quartz diorite porphyries such as are common in the Rocky Mountain region and surely can not be regarded as of the Alkalic series. Its augite is strongly colored by the ægirite molecule but retains a large extinction angle. The rock is richer in alkalies than the kohalaite or any of the cited analogues and is poorer in lime than most of them. It is considerably poorer in lime and normative anorthite than the akerite of Ramnas, cited also by Rosenbusch ${ }^{2}$ as typical of its group of the alkali syenites.

The other monzonite porphyry (d) compared with kohalaite, while not so near it as the rock of the Henry Mountains, is certainly of very similar character. Its associates in the La Plata Mountains, Colo., are monzonite, augite syenite, various quartz monzonite porphyries, lamprophyres allied to camptonite, etc. Some of these might be called alkalic in the Rosenbusch sense, but others do not seem to be so.

Kohalaite has, then, some rather marked chemical features requiring its assignment to an Alkalic series. Its analogues are mainly associates of pronounced alkalic types, partly of calcic assemblages.

Trachyandesites.-The rocks of Haleakala (Division III of the table) are evidently of trachyandesitic character, and their analogues are recognized as of the Alkalic series. Rosenbusch ${ }^{3}$ cites, under trachydolerite, the same analysis of mugearite given in the table and also one of basalt from San Mateo, Sardinia, probably the same rock of which I quote a new analysis by Washington. Lacroix ${ }^{4}$ compares the trachyandesite of Reunion with mugearite. The rock of Bull Cliff, Cripple Creek, Colo., is associated with phonolites in a marked alkalic center. Carmeloite is called an augite andesite by Rosenbusch, ${ }^{5}$ but its normative composition seems to place it systematically very near to the trachyandesite of Haleakala. As the norms show, one phase of the rhombic porphyry of Norway belongs in this group.

Rocks of Mauna Kea.-The lavas of Mauna Kea described by Daly (Division IV of the table) contain much more normative anorthite than the trachyandesites, and although Daly calls one of them trachydolerite, I am not sure where they would have been placed by Rosenbusch on the basis of composition. The analogous rocks of the table are apparently calcic and occur in districts where alkalic rocks also occur. Pirsson ${ }^{6}$ has pointed out this relation of the norite with umptekite, monzonite, camptonite, and gabbro. The basalt of Reunion has both alkalic and calcic associates according to Lacroix. ${ }^{7}$. The andesites of the Yellowstone have not been questioned by Rosenbusch but have various alkalic associates in the park. The rocks of the Harz Mountains seem calcic. Altogether I should say that the Mauna Kea rocks are intermediate but have striking analogues of more clearly calcic affinities.

Rocks of Division V.-The two similar feldspathic basalts of Division V of the table, analyzed but not microscopically described by Lyons, are poor in normative quartz and orthoclase, with anorthite nearly equal to albite. The normative plagioclase would be andesine near labradorite. From the composition they appear to be calcic, and most of the analogues of the table occur in districts where alkalic rocks do not prevail. The olivine dolerite of Skye is included in the table, in spite of its normative olivine, to show the nearest Hawaiian analogue of the rock which, according to Harker, is a part of the same mass as the mugearite of Division III.

These basalts are intermediate and from my standpoint might be expected to have analogues of various associations in different districts.

Rocks of Kilauea's caldera walls.-Division VI of the table deals with three of Silvestri's rocks from the caldera walls of Kilauea, one of which he calls augite andesite. The first two

1 U. S. Geol. Survey Fourteenth Ann. Rept., pp. 176, 226, 1894.

3 Jilemento der Gesteinslehre, 3d ed., p. 132, Stuttgart, 1910.

8 Op. cit., p. 440.

1 Compt. Rend., vol. 155 , p. 540 (analysis 3).

$48730^{\circ}-15-6$

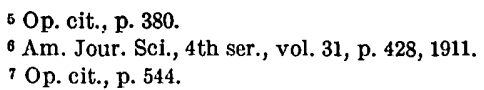

5 Op. cit., p. 380 .

6 Am. Jour. Sci., 4th ser., vol. 31, p. 428, 1911.

7 Op. cit., p. 544 . 
(Nos. 9 and 11) appear to have the chemical character of trachydolerites, for they carry normative nephelite and olivine and are richer in orthoclase than the common basalt of Hawaii. The analogues of these rocks are also rather alkalic types-two of them from Tahiti.

The basalt No. 12, while free from normative nephelite, has a higher proportion of alkali feldspars than the other types of Division VI. The analogous rocks of Japan, New South Wales, and Scotland are recognized by Kozu, Card, and Tyrrell, respectively, as containing more alkali feldspar than normal basalt, and it may be assumed that they belong in the trachydolerite group of Rosenbusch.

The allied rocks of Division VII are so distinctly alkalic through the subordination of normative anorthite that their reference to the Alkalic series can not be questioned. It is interesting to note that one of the analogous types occurs in Cerro San Miguel, Mexico. Three of the analogues of this division are from Sardinia.

Basalts of Oahu.-The Oahu basalts of Division VIII are unusual types, and as they have not been described in detail by Lyons the accuracy of the analyses might be questioned were it not a fact that many Oahu basalts are poor in olivine and rich in bronzite (p. 19). The Oahu basalts have very low potash, and, although alkali feldspars exceed the anorthite in the norms, I should suppose that such magmas must be assigned to the Calcic series. The only close analogues found are not helpful in deciding this question. They are all more calcic and the analyses are more or less questionable, except that by Melville of a somewhat altered rock from Mount Diablo, Cal.

Average lava of Halemaumau.-The relations of the modern lavas of Halemaumau to the so-called Alkalic and Calcic series are of almost critical importance in the discussion of the merits of the theoretical conceptions or systematic uses made of those series. In Division IX of the table is given the average composition of nine lavas of Halemaumau and in Division $\mathrm{X}$ the two most recent analyses. The data of these divisions may well be discussed together.

The analyses and norms give no ground, so far as I can see, for changing the reference of these rocks to the normal basalts, in accordance with the views of all petrographers who have discussed them, unless the normative quartz or low olivine is held to require an assignment to augite andesite. The normative plagioclase of the average is labradorite near andesine.

Let us now apply the three rules given by Rosenbusch as of value in deciding between the alkalic and calcic relations in such cases. First, there is no nephelite or other lenad, normative or modal, and no sodic pyroxene or amphibole. Second, the sum of the alkalies is only about 3 per cent, while 5 per cent is the limit cautiously set by Rosenbusch above which one may suspect trachydoleritic affinities. Third, the character and associations of analogous rocks clearly support the reference to the Calcic series.

Among the closely analogous rocks cited in the table are five Triassic diabases of the eastern United States defined by Rosenbusch as typical of the Calcic series. Besides the cited rocks many others might have been noted, showing a very notable, general, or specific resemblance to several lavas of Hawaii. Rosenbusch ${ }^{1}$ quotes the cited analysis of diabase from West Rock, Conn., as representative of "Hunnediabas."

The Whin Sill of England is also "Hunnediabas," according to Rosenbusch, ${ }^{1}$ who cites an analysis of that rock from Durham corresponding closely to that of a rock from the same locality quoted in Division IX of the table. The Whin Sill is less strongly calcic than the Kilauea lavas with which it is compared.

In Cape Colony, South Africa, Rosenbusch" finds another representative of "Hunnediabas" which is similar to the rock of Colesburg, South Africa, cited in Division IX. The resemblance between the recent lavas of Piton de la Fournaise, on Reunion Island, and those of Halemaumau has been noted (p. 81) and is illustrated in Divisions IX and X. The island of Linosa furnishes another significant analogue.

Basalts of Kauai.-Two adjacent basalt flows of Olokele Canyon, Kauai, cited in Division XI, appear, from analysis and mode, to be highly calcic, though they vary in silica so that one

1 Op. cit., p. 410 . 
has normative nephelite while the other has not. One of these rocks (No. 31) is the chrysophyre contrining modal tridymite and cristobalite. (See p: 11.) The only closely analogous basalt I have found is one from Hesse-Darmstadt. A near analogue is an olivine-hypersthene diabase of Culpeper County, Va., cited by Rosenbusch ${ }^{1}$ as a calcic diabase. Another is an old greenstone diabase of the Lake Superior region.

The second basalt of Division XI has fairly close analogues in basalts of the Azores and Tahiti and a picrite of the Crazy Mountains, Mont. These may be considered by some petrographers as alkalic because of their associated rocks, but the value of such a conclusion is brought in question by the direct association, in Olokele Canyon, of the two rocks of Division XI.

Femic basalts near Honolulu.-The three Oahu rocks of Division XII are of local and comparatively recent eruptions near Honolulu, regarded as extreme products of subsidiary differentiation. (See p. 91.) They undoubtedly show characters requiring their reference, under current ideas, to the Alkalic series, and this conclusion is confirmed by the analogues and their associates. All these lavas belong in the class of lamprophyric effusives recently given definite recognition by Rosenbusch, ${ }^{2}$ who quotes the lava of 1905-6 from Matavuna (a, Division XII) as one of the Alkalic series. ${ }^{3}$

The interesting and significant point here is that of genetic relation to the prevalent hypersthene-bearing, olivine-poor basalts of Oahu, such as are represented in Division VIII, which seem to indicate approximately the probable calcic nature of the original magma of Oahu.

Picritic basalts of Mauna Loa and Haleakala.-Two of the most basic lavas of the large centers are cited in Division XIII. The Mauna Loa flow of 1852 is decidedly calcic as to its normative molecules and has no nephelite. The lava of Haleakala, with considerably more lime and even less soda than the Mauna Loa rock, has normative nephelite, which is so clearly a result of the lower silica that it seems unreasonable to give the nephelite any weight as showing alkalic character.

As to the home associations of these types, the lavas of Mauna Loa are not yet known to include alkalic varieties, and Rosenbusch cites one of these lavas as a true (calcic) basalt. The basalt of Haleakala, however, is closely associated with trachyandesite of undoubted alkalic stamp.

The cited analogues are mostly intrusive rocks or lavas of centers where alkalic types abound, but in Tahiti, at least, other more calcic forms are known. The olivine diabase of Englewood Cliffs, N. J., so very near to the Mauna Loa lava, is one of the Triassic traps of the Eastern States, other members of which resemble lavas of Kilauea, as has been shown above. The analogy with the gabbro of Rosswein is not very close, this rock being relatively alkalic in its salic elements.

Division $X I V$.-The three most femic rocks of Hawaii thus far analyzed are dealt with in Division XIV of the table. Two of these are nearly related chemically-one from Kilauea (No. 42), the other erupted in Puna (No. 41) but perhaps a direct product of the Kilauea reservoir. No. 41 is a picrite basalt and No. 42 is called by Daly porphyritic gabbro, but both rocks are so rich in magnesia and so poor in alumina as to fall with the picrites, these being defined as effusive forms of peridotites, in agreement with Rosenbusch. No Tertiary lavas have been found for comparison with these fresh Hawaiian flows, and the nearest analogues are the picrites and gabbros of Division XIV.

The analogues of the nephelite-melilite basalt (No. 43) are all rocks which must be called alkalic by adherents of the Rosenbusch system.

Résumé.-On applying Rosenbusch's rules to the analyzed lavas of Hawaii, it appears that about 15 of them are referable to the Alkalic series, that a somewhat larger number are as clearly of the Calcic series, and that a smaller number are of questionable affinities. The dominant basalts of the islands, as shown by both chemical and microscopical data, are true basalts, 
or "gabbroic effusives," to use the expression of Rosenbusch, ${ }^{1}$ but essexitic effusives, or trachydolerites, also occur. The alkalic types are known on all the main islands except Molokai, no rocks from that center having been analyzed.

\section{THE ALKALIC AND CALCIC SERIES OF IGNEOUS ROCKS.}

Current views regarding the series.-The sharp and far-reaching distinction between the Alkalic (granito-dioritic) and Calcic (foyaitic-theralitic, alkalicalc) series among igneous rocks is often referred to in petrographic literature as the most important contribution to petrography made by Rosenbusch. The fundamental significance of the distinction is tacitly admitted in most discussions of petrogenesis, and the application of this principle in systematic classification as attempted by Rosenbusch has seldom been criticized. Still it must be admitted by all petrographers that the criteria for separating rocks of the two series have not been clearly formulated and that the generalizations as to occurrence and association deserve the closest' scrutiny on the basis of observation. The study of the Hawaiian rocks, generally treated âs belonging to the Calcic series but including many analogues of alkalic types, furnishes a basis for testing the truth of oft-repeated assertions concerning the natural relations of the two great series.

One may search petrographic literature in vain for a clear statement as to the distinctive characters of the series or the criteria for recognizing them or an explanation why closely similar rocks of intermediate composition must nevertheless be divided between two series. of almost antagonistic relations to each other. When the thoughtful student of the complex relations of igneous rocks reviews the strongly stated generalizations as to the contrasting characters and independent occurrence of the Alkalic and Calcic series, and the basis of fact on which they rest, he must conclude that those generalizations have been hastily drawn and go much too far. There is reason to recall many instances where incorrect and extravagant generalizations have retarded the development of petrographic system.

In the Elemente der Gesteinslehre Rosenbusch carries through, so far as he is able, the distinction between alkalic and calcic rocks, and as his classification in that work is based on chemical dati and is illustrated by tables of chemical analyses, one might naturally expect to find some justification for the idea of the two rock series; but in fact, although the question is of such fundamental importance, it is not discussed at all except incidentally.

The first mention of the two series comes not where the system is outlined but under the description of granite. After the simple statement ${ }^{2}$ that alkali granite contains no lime-soda feldspar, in distinction to alkalicalc granites, follows ${ }^{3}$ the bare, unqualified assertion that the two granite groups occur in different geologic provinces and with different accompanying dike rocks. It is further asserted that alkali granites are associated only with alkali syenites, nephelite syenites, essexites, and their basic relatives, and similar restrictions are placed on the associations of alkalicalc granites. The syenites are avowedly but not actually treated like the granites.

Some of the alkalicalc granites and corresponding syenites cited by Rosenbusch contain less than 1 per cent of lime entering into anorthite, as calculated by him (on the principle of the norm) from the excess of alumina, after soda and potash have been satisfied. One is tempted to inquire how it can be supposed that differentiation may be assumed to have proceeded so far, within the alkalicalc series, without allowing the possibility of the next small step by which the alkalies might increase, relatively, to the point where the molecular ratio of alkalies to alumina becomes $1: 1$.

It is noted by Rosenbusch ${ }^{4}$ that the alkalicalc granites are very much more abundant than the corresponding syenites. That peculiar situation is, in my opinion, due mainly to the fact that lime feldspar bearing associates of alkali granites are, on an arbitrary principle, not recognized by Rosenbusch as possible, while larvikite, akerite, and other rocks carrying considerable normative anorthite are treated as alkali syenites (!) and as grading in to the monzonites, a truly intermediate group, which Rosenbusch is forced to treat as belonging with
1 Op. cit., p. 402.
${ }_{2}^{2}$ Idem, p. 78.
${ }^{3}$ Idem, p. 84.
1 Idem, p. 119. 
the Alkalic series. He recognizes the fact that an alkali granite can not grade through quartz monzonite and granodiorite into quartz diorite, or the distinction of Alkalic and Calcic series fails, even among the most highly salic rocks.

The distinction of essexites and trachydolerites, through their inherent characters as alkali rocks, from gabbro and basalt is admitted by Rosenbusch ${ }^{1}$ to be at the present time impossible because the characteristic differences have not as yet been fully determined, but he believes such differences exist.

In his "Massige Gesteine," on page 1159, Rosenbusch takes the impregnable position that he would not consider himself justified in assigning a given rock to trachydolerite or basalt proper when the evidence of the rock itself does not suffice to indicate such assignment. But in the "Elemente," on page 402, he lays down certain rules (Regeln) which may be used in assigning a basaltic rock to trachydolerite. These rules are cited here to serve as the best available basis for judging whether the Hawaiian basalts may be referred to the Alkalic or calc-alkalic series in the sense of Rosenbusch.

The rules are briefly as follows: (1) The presence of even the smallest amount of nephelite, leucite, sodalite, or other lenad or of alkali-pyroxene or alkali-amphibole shows the rock to be a trachydolerite. (2) More than 5 per cent of combined alkalies, especially with high potash, does not speak for true basaltic character. (3) Geologic association with alkali trachyte, phonolite, or other alkali rocks speaks for the trachydoleritic nature, and association with trachyte, andesite, dacite, etc., for the true basaltic character.

The third rule clearly violates the principles set up by Rosenbusch for his own guidance, as above quoted, and is manifestly illogical and misleading so long as there is any question of fact as to whether clearly marked alkalic and calcic types occur together. The second rule is certainly vague enough and has no practical application to Hawaiian basalts, in many of which the combined alkalies exceed 5 per cent, though in most they are much less than 5 per cent.

The first rule is an exaggerated statement based on facts in the association of many rocks. As to nephelite and leucite, particularly, its universal applicability may be questioned. It seems to me that nephelite has long been given a systematic importance in the qualitative systems of classification far beyond its merits. Its presence in moderate amount is not so much an indication of highly sodic or alkalic character of a magma as of relatively low silica. Like olivine, nephelite and leucite are dependent for their development on physical conditions as well as chemical relations.

Rosenbusch ${ }^{2}$ remarks as to olivine: "The absence or presence of olivine is not a consequence of the chemical composition of the magma but of the conditions of crystallization and specially of the more rapid or slower consolidation and the corresponding shortened or lengthened period of resorption." As has been repeatedly pointed out in this paper, an abnormative development of olivine must free silica, which becomes available to increase the silicity of other molecules, and may prevent the formation of small amounts of nephelite. There may be conditions which increase the amount of nephelite.

Probably all petrographers recognize that there are recurrent peculiarities in the rocks of different regions which are apparently derived from similar parent magmas. Iddings, Brögger, Lacroix, Washington, and many other students of notable areas have made this conclusion incontestable. Rosenbusch has made it the basis of systematic classification. But has he not gone much too far in the sharp distinction of the Alkalic and Calcic series and the generalization, to which he gives all the force of an established law, that the members of the two series do not and may not occur together as differentiation products of one magma? Is there not a mass of evidence to prove that types of the two assumed series do mingle in many petrographic provinces or centers of eruption, as differentiates from the same parent magma? Before such a general law can be accepted as a basis for systematic classification is it not incumbent on petrographers to demand at least a reasonable hypothesis to explain why two similarly constituted magmas, one an andesite and the other a trachyandesite, or one a basalt and the other a trachy- 
dolerite, may not on differentiation produce many similar and even identical types? If such overlap is impossible, why is it not also true of the derivatives from two basaltic or two trachydoleritic parent magmas, which may well differ from each other in composition more than many pairs of rocks whose analyses are quoted by Rosenbusch, one of trachydolerite and the other of basalt?

The facts presented concerning the Hawaiian lavas and their relations seem to furnish significant data, bearing on these questions, which will be discussed in the next section.

Distinction between Alkalic and Calcic series.-The chemical characters of Hawaiian lavas and the circumstances of their association demonstrate that so-called alkalic and calcic magmas may and do occur together as derivatives from a common source. This evidence is supported by the facts of many other eruptive centers, some of which will be cited. The current generalization-always largely assumption-that this distinction between the Alkalic and Calcic series is of fundamental importance in petrogenesis and may serve as a factor in a natural system is, in my opinion, absolutely false and is leading to needless confusion in various problems of igneous rocks.

Much of the world-wide evidence bearing on this question is not readily put in convincing form. The table of analogues of Hawaiian lavas presents many suggestions for further investigation, when the new edition of Washington's Tables is available. A general review of the subject has led Iddings ${ }^{1}$ to express his belief that the distinction under discussion is not in accordance with the facts of nature.

Studies of Tahiti and Reunion have led Lacroix ${ }^{2}$ to the clearly expressed conclusion that in those islands alkalic and calcic magmas are comagmatic associates. Weber's studies of Samoan lavas resulted in the same conclusion for that island group, in spite of an evident predisposition to accept the Rosenbusch generalization. Weber ${ }^{3}$ mentions several places, in different countries, where alkalic and calcic rocks occur together, and raises the question whether the idea as to the separation of the series has not been carried too far. Washington has shown in a recent study of rocks from Sardinia that alkalic and calcic rocks are there associated as derivatives from the same magma, and he expresses the opinion that the Rosenbusch generalizations are incorrect. Many other writers have pointed out instances where rocks of the two series are associated, but in many such instances it has not been clear that the rocks were of the same period of eruption and were genetically associated.

\section{DIFFERENTIATION OF HAWAIIAN MAGMAS.}

The general problem.-It appears to be impossible to escape from the conclusion that the series of Hawaiian lavas have been derived from a general magma of nearly the same character in all parts of the province. . The origin of this provincial magma is a still broader problem, beyond the scope of this discussion. The process or processes involved in this secondary differentiation are perhaps no more clearly indicated by definite evidence here than in other regions, and I confess to the feeling that all current hypotheses fail to render satisfactory explanation of all the phenomena or relations observed. And in the present state of knowledge (or of ignorance) concerning the processes of differentiation, it is reasonable, I think, to believe that there may be forces operating on magmatic solutions in the chambers or conduits of the earth's crust, the potency of which to produce the observed results has not been appreciated, or even that there may be forces of which we are now ignorant.

Speculation and the formulation of hypotheses and theories on this subject are highly desirable and may be of great value, but it is only necessary to review the recent literature of magmatic differentiation to make it clear that there is no adequate basis of physical and chemical facts pertaining to this question from which speculation and hypothesis must start. The fact that Daly has recently published a paper on the differentiation of Hawaiian magmas gives a natural trend to the brief discussion which follows.

1 Igneous rocks, pt. 2, p. 464, New York, 1913.

¿Soc. géol. France Bull., 4th ser., vol. 10, pp. 91-124, 1910; Compt. Rend., vol. 155, pp. 538-544, 1913.

8 K. bayer. Akad. Wiss. math.-phys. Klasse Abh., vol. 24, pt. 2, p. 305, 1909. 
The first essential is, as Daly remarks, to establish the approximate character of the parent magma, as nearly as may be, to review the composition of the known products of differentiation, and then to consider the processes involved.

The provincial magma.-The composition of the parent magma of the Hawaiirn province can not be closely determined, of course, but the average composition of rocks analyzed seems likely to be nearly representative of the general Hawaiian magma. A large number of the Hawaiian analyses are of the basaltic types, so that the rare and more or less imperfectly complementary extremes.have less effect on the average than is commonly the case when similar avernges have been calculated, with fewer analyses.

In the subjoined table the column marked $\alpha$ represents the average of the 43 analyses of the table on pages $47-48, \beta$ is the average of 29 analyses of lavas of the island of Hawaii, $\gamma$ is the average of 9 analyses of lavas of Halemaumau, of the "C.-O,-A. group" discussed on page 60; $\delta$ is the average of 198 analyses of basalt, calculated by Daly ${ }^{1}$ to represent the world basalt; $\varepsilon$ is the analysis of the dolerite of Londorf in Hesse, quoted by Rosenbusch ${ }^{2}$ as a type of true or calcic basalt. The norms corresponding to the averages and the Londorf rock are also given.

Average analyses and.norms of lavas.

\begin{tabular}{|c|c|c|c|c|c|c|c|c|c|c|c|}
\hline \multicolumn{6}{|c|}{ Analyses. } & \multicolumn{6}{|c|}{ Norms. } \\
\hline & $\alpha$ & $\beta$ & $r$ & $\delta$ & $\varepsilon$ & & $\alpha$ & $\beta$ & $r$ & $\delta$ & $\varepsilon$ \\
\hline \multirow[t]{3}{*}{ 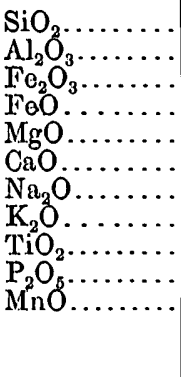 } & $\begin{array}{r}48.00 \\
14.00 \\
5.03 \\
8.01 \\
7.12 \\
9.00 \\
3.55 \\
1.24 \\
2.29 \\
.49\end{array}$ & $\begin{array}{r}50.12 \\
14.32 \\
4.61 \\
8.52 \\
6.23 \\
8.82 \\
3.31 \\
1.25 \\
1.37 \\
.22\end{array}$ & $\begin{array}{r}50.18 \\
14.12 \\
3.04 \\
10.45 \\
6.42 \\
10.67 \\
2.69 \\
.75 \\
1.75 \\
.21\end{array}$ & $\begin{array}{r}49.06 \\
15.70 \\
5.38 \\
6.37 \\
6.17 \\
8.95 \\
3.11 \\
1.52 \\
1.36 \\
.45\end{array}$ & $\begin{array}{r}49.08 \\
13.43 \\
6.49 \\
5.92 \\
9.58 \\
8.92 \\
3.42 \\
1.00 \\
1.82 \\
.51\end{array}$ & \multirow[t]{3}{*}{$\begin{array}{l}\text { Orthoclase } . . \\
\text { Albite } . . . . \\
\text { Anorthite } . . \\
\text { Diopside ..... } \\
\text { Hypersthene } \\
\text { Olivine } . . . \\
\text { Magnetite } . . \\
\text { Ilmenite } . . . \\
\text { Apatite } . . . .\end{array}$} & $\begin{array}{r}7.23 \\
29.87 \\
18.63 \\
18.57 \\
3.46 \\
9.33 \\
7.19 \\
4.41 \\
1.16\end{array}$ & $\begin{array}{r}7.78 \\
27.77 \\
20.29 \\
17.89 \\
11.42 \\
4.18 \\
6.73 \\
2.58 \\
.52\end{array}$ & $\begin{array}{r}4.45 \\
22.53 \\
24.19 \\
22.42 \\
17.02 \\
1.48 \\
4.41 \\
3.34 \\
.51\end{array}$ & $\begin{array}{r}8.90 \\
26.20 \\
24.46 \\
13.60 \\
12.07 \\
1.70 \\
7.89 \\
2.58 . \\
1.07\end{array}$ & $\begin{array}{r}6.1 \\
28.8 \\
18.3 \\
17.6 \\
8.3 \\
7.0 \\
9.3 \\
3.5 \\
1.3 \\
\end{array}$ \\
\hline & 41 & .43 & .19 & .31 & ......... & & 99.85 & 99.16 & 100.35 & 98.47 & 100.2 \\
\hline & 99.83 & 99.20 & 100.47 & 98.38 & 100.17 & & & & & & \\
\hline
\end{tabular}

Rocks of the composition of the averages $\alpha$ and $\beta$ and the dolerite of Londorf fall in subrang camptonose (III.5.3.4) and are not transitional in any respect. The Londorf rock corresponds to the general average $\alpha$ in its normative composition more closely than any other basalt of which I have found an analysis. The "C.-O.-A." average of Halemaumau ( $\gamma$ ) falls in subrang auver- gnose (III.5.4.4-5) through its lower soda but is transitional to camptonose. The world basalt of Daly $(\delta)$ is more salic than. the Hawaiian averages, in consequence of its higher alumina, and is andose-camptonose ((II)III.5.3.4).

The data at hand seem to require that a discussion of differentiation in the Hawaiian province should assume the parent magma to have had nearly the composition of the concordant averages $\alpha$ and $\beta$, and that lavas of widely variant composition have been derived from that magma by differentiation, directly or indirectly.

The differentiates.-Whatever the parent magma may have been, the nature of the differentiation that has taken place is represented, though doubtless imperfectly, by the rock analyses which have been cited. An examination of the analyses and of the table of normative ratios (opposite p. 56) will show the important phases of this differentiation in many details. A summary of the leading features of variation from the mean of the 43 analyses $(\alpha)$ may be of interest at this place.

With regard to the relation $\frac{\text { Sal }}{\text { Fem }}, 21$ rocks are more salic and 22 more femic than the mean. At the salic extreme are three rocks separated by a large gap from the next most salic type (No. 4), while there is a more continuous gradation through the more femic part of the series. 
The variation in silica in these rocks has some interesting features. Only three rocks are notably higher in $\mathrm{SiO}_{2}$ than the mean, and five are somewhat poorer in it. For 34 rocks the variation in $\mathrm{SiO}_{2}$ is but 3 per cent on either side of the mean of 48.69 , yet these rocks range in the quantitative system from near the middle of Class II well into Class IV, showing how relatively unimportant the variations in $\mathrm{SiO}_{2}$ may be compared with those of the bases. Two of the most femic rocks have only about. 2 per cent less $\mathrm{SiO}_{2}$ than the mean.

In these rocks $\mathrm{SiO}_{2}$ does not vary in accord with any other particular constituents While the most alkalic are also the most siliceous rocks, Nos. 3 and 4 have the same contents in $\mathrm{Na}_{2} \mathrm{O}$, nearly equal combined alkalies, and about 10 per cent difference in $\mathrm{SiO}_{2}$.

The variation in alumina is much more important than that in silica, both quantitatively and for its influence on the mineral composition. While in many of the rocks $\mathrm{Al}_{2} \mathrm{O}_{3}$ varies with $\mathrm{Na}_{2} \mathrm{O}$ or the combined alkalies, in some high $\mathrm{Al}_{2} \mathrm{O}_{3}$ goes with low alkalies, causing a great increase in normative anorthite, as in Nos. 8, 9, 11, 17, and 22. Among the more femic rocks the relations of $\mathrm{Al}_{2} \mathrm{O}_{3}, \mathrm{SiO}_{2}$, and alkalies are also extremely variable. Thus in Nos. 33 and 37, each with 12.10 per cent $\mathrm{Al}_{2} \mathrm{O}_{3}$, the $\mathrm{SiO}_{2}$ is high and alkalies low in the former and the reverse in the latter rock.

Lime is also independent of other oxides in its variations. Rocks carrying less $\mathrm{CaO}$ than the mean are scattered through the list from No. 1 to No. 42, the $\mathrm{SiO}_{2}$ ranging in these same rocks from 62.19 to 36.85 per cent. No. 36 has the same $\mathrm{CaO}$ as the mean, with 12 per cent less of $\mathrm{SiO}_{2}$, and No. 28 has the same $\mathrm{CaO}$ with 3 per cent more $\mathrm{SiO}_{2}$ than the mean, so that there is a range of 15 per cent in $\mathrm{SiO}_{2}$ with the same $\mathrm{CaO}$ contents.

The alkalies range from 1.61 per cent (No. 42) to 13.31 per cent (No. 2), and while the most salic rocks are highest in alkalies there is no regular variation, as a glance at the table will show. Soda is much more abundant than potash and there is a tendency for the two to vary in accord, though some exceptions are notable.

The most variable constituent oxide of the Hawaiian magmas is magnesia. It ranges from 0.16 to 21.79 per cent and goes even higher in the peridotitic xenoliths. There is a general increase in magnesia with increase in femic molecules of the norm. This is natural, for $\mathrm{MgO}$ is only found in femic silicates.

The determinations of the iron oxides are open to so much question as to their accuracy that it is best to consider the variation in the total iron contents of the rocks. While it would be more accurate to calculate all the iron to $\mathrm{FeO}$, this is unnecessary for the general purpose of the present discussion, for it is manifest that iron is not.distributed in the same manner as magnesia, in spite of the fact that its normative compounds are all in the femic group. A glance at the table of analyses, which are arranged on the ratio of $\frac{\text { Sal }}{\mathrm{Fem}}$, will show that the amount of iron is most strikingly independent of the abundance of femic molecules. In No. 4, with 37.6 per cent of $\mathrm{Fem}$, there is 10.54 per cent of iron oxides, while in No. 42, with 72.7 per cent of $\mathrm{Fem}$, the iron oxides form but 12.66 per cent. Rocks numbered 12,13,15, and 16, all of which belong to the transition zone between Classes II and III, are richer in iron than any four rocks of Class IV, or, indeed, than any of the entire 27 rocks richer in femic molecules. Among the rocks more femic than the average $(\alpha)$ only four are richer in iron, while seven more salic rocks have higher iron contents. The variations of all other principal constituents are greater than those of iron.

It has been pointed out that Silvestri's analyses are apparently too high in iron oxides, but the general statement in regard to the variation in iron is true, even if all Silvestri's analyses are disregarded.

Titanic oxide shows no special tendency to concentration, being distributed quite independent of the ratio $\frac{\text { Sal }}{\text { Fem }}$.

Processes of differentiation.-The results of differentiation in Hawaii are known only as effusions, with a few dikes near the surface. No large intrusion, no stock or conduit has been. found. The differences in composition shown by the lavas are such as may originate in the space 
belonging to the volcano, in its conduit, or in the chamber or reservoir for its magma. Assimilation of foreign material can not be plausibly assumed to have modified the magma, as it is supposed to have done in many other igneous centers.

Daly ${ }^{1}$ has approached the problem from practically the same standpoint and explains the formation of the more mafic and felsic lavas by certain definite processes. Gravitative adjust- ment within the conduit is thought ample to explain the ultrafemic and some of the salic lavas, while the assimilation of coral limestone has indirectly led to the formation of the rare trachyte, in accordance with the hypothesis formulated by him a few years ago. ${ }^{2}$

Let us see how far the facts contribute support to Daly's hypotheses.

Gravitative differentiation.- - It is not difficult to conceive of a kind of differentiation due to gravitative adjustment in a body of magma containing heavy crystals of olivine, pyroxene, magnetite, etc., in a still liquid, lighter, salic residue - given sufficient time. But apparently this process is more readily conceived in the study than carried out in nature; for, while there are a goodly number of intrusive sills and laccoliths where a concentration of the heavier constituents in the lower zones has been plausibly attributed to this process, such concentration is conspicuously absent in a vastly larger number of apparently similar occurrences. I have not found any such case in many seasons' experience in the examination of intrusive bodies.

Daly explains the more mafic lavas as due to the sinking of heavy silicates by gravity to low levels in the volcanic conduit, where they are resorbed and gradually change the character of the dissolving magma. At the same time the magma of the upper part of the conduit becomes more salic. After extensive changes of this kind an eruption from the upper portion of the conduit would produce andesitic or similar lavas, while if the deeper parts of the lava column were tapped highly femic magmas, such as the Mauna Loa flow of 1852 , would come to light. He says ${ }^{3}$ that "no fact in the field relations opposes the assumption of a very deep, direct source for these heary magmas."

The facts that the 1852 flow issued from Mauna Loa 1,300 meters below its summit and that the porphyritic gabbro of Kilauea occurs 3,000 meters below the same level are cited in favor of the assumption. To these data may be added the occurrence of the olivine-rich basalt of Puna at sea level and of the picritic basalt of Haleakala at its summit. This range of level for the four heaviest known lavas of Hawaii and Maui scarcely supports any generalization as to a relation between the specific gravity of a lava and the level of its issue.

The complementary proposition, that lighter lavas are apt to occur at higher levels, is thought by Daly ${ }^{4}$ to be illustrated in Mauna Kea. This mountain is described as practically stratified, in that it is supposed to consist of olivine basalt below 6,000 feet and generally lighter rocks above that level to the summit, where the lightest rock, trachydolerite (No. 5), occurs. Here, again, Daly's data are, I think, obviously inadequate to serve as the basis for such a conclusion. His observations appear to have been limited to a traverse from the saddle on the south, at about 6,000 feet, to the summit and back, the usual route of approach. The constitution of this great volcano is still almost unknown by direct study of its lavas.

But even if lavas lighter than normal basalt descend on all sides of Mauna Kea to about 6,000 feet, they must be considered as simply a veneer of the later eruptives and give no evidence of the character of underlying lavas, which must have descended likewise from vents above. Moreover, the collection studied by Cohen ${ }^{5}$ and that made by Preston ${ }^{6}$ showed the presence of heavier basalts on the upper slopes of Mauna Kea, though their distribution and occurrence are unknown.

The occurrence of very mafic and felsic lavas together at the summit of Haleakala has been described (pp. 28-30). Trachytic rocks occur at low levels on both Hawaii and Maui, and on reviewing the data of occurrence at my disposal I can see no sufficient basis for the generaliza-

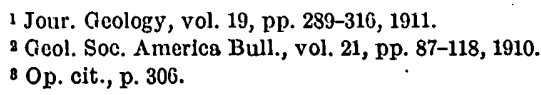

1 Jour. Geology, vol. 19, pp. 289-316, 1911.

2 Cieol. Soc. America Bull., vol. 21, pp. 87-118, 1910.

B Op. cit., p. 306.

1 Idem, p. 310.
s Neues Jahrb., 1880 , vol. 2, pp. 23-62.

6 U. S. Coast and Geodetic Survey Ann. Rept., 1893, pt. 2, appendix 12. 
tion that on Mauna Kea or in the Hawaiian Island group the more basic (that is, heavier) lavas have issued more frequently from lower levels while the lighter ones characterize the upper slopes of the volcanoes.

Mauna Kea is the only one of the great volcanoes of Hawaii in which the occurrence of the lighter lavas near the summit is supposed by Daly to be in accord with the gravitative hypothesis. At the other centers the conditions are recognized as having been unfavorable to . gravitative differentiation, mainly on account of the energetic "two-phase connection," a process resulting in the vesiculation of the magma at considerable depth. ${ }^{1}$

Origin of trachyte and melilite basalt.-Daly considers that the soda trachyte of Puu Waawaa and the nephelite-melilite basalts may have resulted from the absorption of coral or foraminiferal limestones, "such as are known to be interbedded with the older lavas of the archipelago," and according to the process formulated by him to explain the alkalic rocks in general. ${ }^{3}$ The occurrence of soda trachyte and nephelite-melilite basalt in proximity on Maui would presumably be considered by him as favoring such an explanation.

With regard to this hypothesis I can see no reason for supposing that the rocks mentioned are not, in Hawaii and elsewhere, products of the same general process of differentiation as the other rocks with which they are associated. They are simply the extreme phases of the group now known and are connected by intermediate lavas with rocks assumed by Daly to result from gravitative differentiation. To be sure, the trachytes do not occur at the summits of volcanoes, but that does not form a valid reason for excluding them from the category of phenomena having a bearing on the gravitative hypothesis.

I am not aware of any basis for the broad statement that limestones are generally associated with the older lavas of the archipelago, nor indeed that they occur in such association at any point. Coral rock is known on the south shore of Oahu at considerable depths and to some extent alternating with lavas and ash beds, but that these belong to the old lavas of the principal centers rather than to later eruptions is not demonstrated and is, indeed, questionable. The limestones occur in what Hitchcock ${ }^{4}$ calls the Pearl Harbor series, which Dall considers to be of late Tertiary age. The sweeping conclusion drawn by Hitchcock, ${ }^{5}$ on the basis of the character of this series, that "there is ground for the belief that the foundation of the whole archipelago is a Tertiary limestone traversed by eruptives," needs some statement of that ground.

Granting that there may be superficial deposits of coral limestone about some of these islands, it is necessary, for Daly's hypothesis, to show how such material can gain access to the volcanic conduit in mass sufficient to produce any notable result. It is certainly true that the alkali-rich lavas are not present about Honolulu, where the limestone deposits are best known. By Daly's hypothesis for the alkalic rocks the felsic lava should be at the upper levels and the mafic below. If this arrangement existed at the time of the numerous subsidiary eruptions about Honolulu, it seems remarkable that no alkalic magma came to eruption.

The importance attached to the association of limestones and alkali rocks emphasized by extensive tables in Daly's original paper presenting his hypothesis ${ }^{6}$ appears to me quite unwarranted. If an alkali rock cuts a limestone in dikes or stocks, this fact proves that that limestone did not have anything to do with the alkalic character of the crosscutting body. The fortuitous association of limestone and alkali rocks in many parts of the world is natural enough, but that it. has any significance for this problem remains to be shown. The few known cases where magmas have been injected into limestones under conditions causing assimilation and reactions leading to important modifications of the magma appear to be of local importance only. The interesting hypothesis recently advanced by Smyth ${ }^{7}$ that magmatic mineralizers have had an important part in the concentration of the alkalies and of other rare elements of ten found in pegmatites, deserves careful consideration. The general conclusion of Smyth that alkalic rocks are simply special derivatives from a "subalkalic" magma agrees entirely with my own views.

\footnotetext{
1 Jour, Geology, vol. 19, p. 311, 1911

2 Idem, p. 309.

5 Idem, p. 33.

3 Geol. Soc. America Bull., vol. 21, pp. 87-118, 1910 .

6 Geol. Soc. America Bull., vol. 21, pp. 92-109, 1910

6 Geol. Soc. America Bull., vol. 21, pp. 92-109, 1910 .
7 Am. Jour. Sci., 4th ser., vol. 36, pp. 33-46, 1913:
}

1 Idem, vol. 11, p. 32, 1900 . 
Differentiation and the sequence of lavas.-The exhaustive descriptions of Kilauea given by Dana, Hitchcock, and Brigham, together with comparatively meager observations of less accessible centers, have made that the accepted type of basaltic volcano of the world. Nevertheless this type is usually described in terms suggested by observations bearing on only a part of the history of such a volcano. That this is true will be appreciated by any geologist seeking to compare the sequence of chemically different lavas in relation to the life history of the volcano.

The early periods of each center are actually unknown, either as to their physical phenomena or as to the character of the lavas. There has been no attempt to examine, except in a casual way, the eroded core of any Hawaiian volcano. It has been tacitly assumed that the early lavas of all were basalts comparable to those of Kilauea. Perhaps they were, but it is certainly desirable to ascertain the facts at the most deeply dissected centers of Kauai, Oahu, and the remnants of large volcanoes presented by some of the smaller islands.

While the older history is difficult to unravel, there is a later period which has received very slight attention, except from its physical side, although the data for its study are very abundant on all the larger islands. This period began at about the time when the great low-arched shield of the volcano was complete and eruptions of the common types had ceased. But apparently volcanism was by no means fully extinct at this time, and it came again and again to eruptive manifestation during the long epoch of dissection and destruction of the volcanic pile.

While my own observations are quite insufficient to permit an adequate sketch of the phenomena of this later period, the problem of differentiation in Hawaii is so bound up with its history that I wish to outline what seems to me the general character of the epoch of decadence in volcanic activity and its relation to the chemical composition of the recent lavas.

Mauna Loa and Mauna Kea are twin giants of the same general size and low dome or shield outline. The former is still active and the latter is referred to as extinct. A striking difference between them is found in the great number of cones of ash and cinders, with or without local flows, which are scattered over the surface of Kea and are rare or lacking on Loa. Whether such subsidiary eruptions occurred in the earlier history of these volcanoes or not, they were certainly more abundant in and characteristic of the decadent period. There are cones and local flows in Puna, adjacent to Kilauea, which seem plausibly related to that center.

These small eruptions were not confined to the time immediately after the cessation of the normal type of basaltic eruption, by which the mountains had been built up, but were repeated at intervals long after the mountains had been dissected even to the point where it becomes difficult to locate the old center of eruption.

Apparently these subsidiary outbreaks were at first most numerous on the upper slopes of a volcano, as indicated by their distribution on Mauna Kea and Hualalai, but as the main conduit became more and more effectively clogged the spasmodic outbreaks occurred more frequently on the lower slopes. In West Maui, Oahu, and Kauai many of the more recent ash eruptions have occurred at or near sea level. On Oahu and Kauai ash and cinder deposits occur at various altitudes on ridges and in canyons or on precipitous slopes, and I have the impression that some of these deposits were not derived from visible centers of lower level.

The relation of this subsidiary volcanism to magmatic differentiation appears in the fact that the more salic and femic lava types are as a rule products of these recent and local eruptions. I am not in a position to assert either that they are restricted to such outbursts or that all lavas of these eruptions are of highly differentiated character. But that such is the general rule is well established.

As I look at it, the relations of magmatic differentiation, as suggested by the sequence of lavas, to the history of Hawaiian volcanoes corresponds approximately to the following outline. If we assume that the initial magma at each center of eruption was of a basaltic character, similar to the average $\alpha$ of the table on page 87, it seems that during the more active period of each volcano differentiation was seldom if ever able to produce partial magmas of extremely salic or femic character. This might be due to short periods of quiet in the magma chamber or reservoir, insufficient to produce great differentiation. Even between eruptive periods there 
might be internal movements of the magma, accompanying changes of temperature, sufficient to again mingle parts of somewhat different composition. At any rate the lavas of extreme composition are not known in the main mass of any volcano.

The "ultrafemic basalt" of 1852, from Mauna Loa, and possibly some other similar lavas may be exceptions to this generalization. But it is also possible that such lavas indicate a slowing of the activity at any center and the beginning of a period in which differentiation is able to produce more femic or more salic magmas than before. Further investigation is necessary to determine how early in the sequence of lavas at a given volcano such femic magmas may appear.

No very salic lavas have been found on Mauna Loa or Kilauea. The interesting rocks belonging to andose; found on the upper slopes of Mauna Kea by Daly, are probably products of subsidiary eruptions. Daly states that the "trachydolerite" of which he submits an analysis (No. 5) issued from a cinder cone near the summit. All the flows of this rock are said to be short and some were seen to be connected with cinder cones. . The similar "andesitic basalt" (No. 7) is not reported by Daly to have such evident connection with these recent and local eruptions, but there are reasons, presented in another place (p. 89), for objecting to the view of Daly that all the upper 6,000 feet of Mauna Kea is composed of these salic lavas. It seems to me that they can be only a veneer-and probably not continuous, at that-over the basaltic summit of the mountains.

Very little is known concerning the constitution of the old volcanic center represented by the mountains of the Kohala district, forming the northern peninsula of the island of Hawaii. Dutton's general statement that the lavas are, as a rule, more nearly andesitic than basaltic ${ }^{1}$ must be questioned in view of the occurrence of normal basalts (of unknown localities) described by Cohen. ${ }^{2}$ The highly salic kohalaite and another rock analyzed by Lyons (Nos. 3 and 10) came from the southern slope of the mountain near Waimea, and as the map of Hawaii shows subsidiary cones to be abundant on that slope, as well as scattered over other parts of the peninsula, it is not unreasonable to assume that the salic lavas came from the late eruptions of the Kohala center and that the main mass may be of common basaltic rocks.

The genetic relations of the soda trachyte of Puu Waawaa and the Anahulu terrace (p. 35) are as yet questionable. Puu Waawa seems to belong among the subsidiary cones of Mount Hualalai but is older than some of its basaltic lavas. The similarity between this trachyte and that near Lahaina, on Maui, suggests a very late date for the former in the history of the center to which it belongs. The query then arises, May the trachyte of Puu Waawa be in fact an outlying eruption belonging to the Kohala center, which by chance comes in proximity to Hualalai ? Further observations are necessary on this point.

The salic lavas of Haleakala, on Maui, of which two analyses have been given (Nos. 4 and 6), are, with the accompanying picritic basalt (No. 39), products of the most recent eruptions of the crater of that volcano. (See p. 30.) Apparently these are the only rock types of Haleakala that have been studied, and there is no distinct evidence of the rôles they play in the constitution of that great volcano. My own view of the relations at the summit of Haleakala rests on meager observations and may be quite incorrect, but I give it, with some hesitation, chiefly as a suggestion to future students of that grand volcano.

What is commonly called the crater of Haleakala appears to me to be, in some part at least, a result of erosion. This great crater is about 7 miles long by 2 miles wide. At the east end, opening to the south, is the Kaupo Gap, 1 mile wide, and at the west end, opening to the north, is the Koolau Gap, 3 miles wide. The'Koolau Gap connects directly with the deep canyon-like Keanoe Valley, which extends 8 or 9 miles to the sea. There is no canyon south of the Kaupo Gap because it has been filled by great flows of trachyandesite extending from the crater to the sea. The Government map represents flows as extending for more than 2 miles from the Koolau Gap down the Keanoe Valley. East of the borders of the flow through the Kaupo Gap are canyons which do not head so far back as the crater but whose beds are deeper than the surface of the flow. These canyons and many others shown by the map indicate the character of the 
gorge which once penetrated through the Kaupo Gap into the summit crater. How much of the crater is erosional remains to be determined.

The absence of any data as to the character of the rocks of the crater or canyon walls makes it uncertain at the present time whether the trachyandesite and picritic basalt had a part in the constitution of the volcano before the gaps were made or not. J. D. Dana says that the walls of the crater are made up of rock similar to that of the cone called White Hill-trachyandesite-but no specimens were collected, and this statement needs confirmation. Dana's collection from Maui contains two specimens of trachyandesite, said to occur near Paia, on the coast at the north base of the mass of Haleakala. It is not known whether these specimens represent lavas of the main mountain complex or local eruptions. A cone occurs near Paia.

Until evidence to the contrary has been procured it seems most natural to assume that Haleakala is, like other Hawaiian volcanoes, essentially basaltic, and that the extreme salic and femic rocks known from its crater belong to subsidiary eruptions, later than most of the canyon erosion to which the mass has been subjected.

There are numerous cinder cones on the slopes of Haleakala, but the nature of their lavas has not been determined.

West Maui presents another great volcanic pile of which little is known. On its slopes are many cinder cones with small flows. At one of these, near Lahaina, on the west coast, occurs the soda trachyte (No. 1) first mentioned by Dana and identified also by Möhle, who found it, together with melilite basalt; among the specimens collected by Schauinsland in the same vicinity. This occurrence seems to connect the most felsic with one of the most contrasting or complementary mafic types, as genetically closely related.

About Honolulu, Pearl Harbor, and many other low-lying parts of Oahu are numerous cinder cones, and, as has been shown (pp. 20-24), the ashes and lavas from them are usually of very basic character; including nephelite-melilite basalt, nephelite basalt, limburgite, and other unusual types. No felsic rocks are known from these vents, but the association of extreme felsic and mafic types near Lahaina confirms the reasonable idea that complementary felsic magmas probably exist in depths at Oahu but have not come to eruption. The perfect forms of Punch Bowl, Diamond Head, and other cones or crater hills of unconsolidated materials show how recent they are, and there is no reason to be confident that further eruptions may not occur on the island of Oahu.

On Kauai conditions are similar to those on Oahu. The most mafic lava of the island is the nephelite-melilite basalt of Kilauea Bay (No. 43), on the north shore, which is of local origin. Cones, with or without craters, are scattered over the island, less abundantly than on Oahu, but the character of the materials erupted in most of them has not been determined.

General course of differentiation.-From the preceding data concerning the differentiates of the Hawaiian primary magma and their time relations to the activity at various centers some tentative conclusions may be drawn.

1. It does not seem probable that there has been any noteworthy differentiation in the main reservoir beneath the Hawaiian district. It being supposed that some volcanoes are much younger than others, the recent ones appear to have presented the same variety of basaltic types during their main activity.

2. During the active growth of each volcano the lavas presented a moderate variability in composition without detected system of variation. The processes of differentiation were too frequently interrupted to permit strongly pronounced results.

3. With decreasing eruptive activity and possibly attendant contraction and limitation of lava chambers, a higher degree of differentiation was accomplished and is shown by more salic and correspondingly more femic lavas than those of earlier date.

4. In the long period of parasitic or subsidiary eruptions conditions were favorable to extensive differentiation. This may be due to a localization of smaller magmatic chambers or to lengthened intervals of quiet.

5. The processes of this differentiation are still problems for investigation. To me they appear to have acted mainly upon the liquid magma. Movement, under gravity, of crystal particles may have played a part. 



\section{INDEX.}

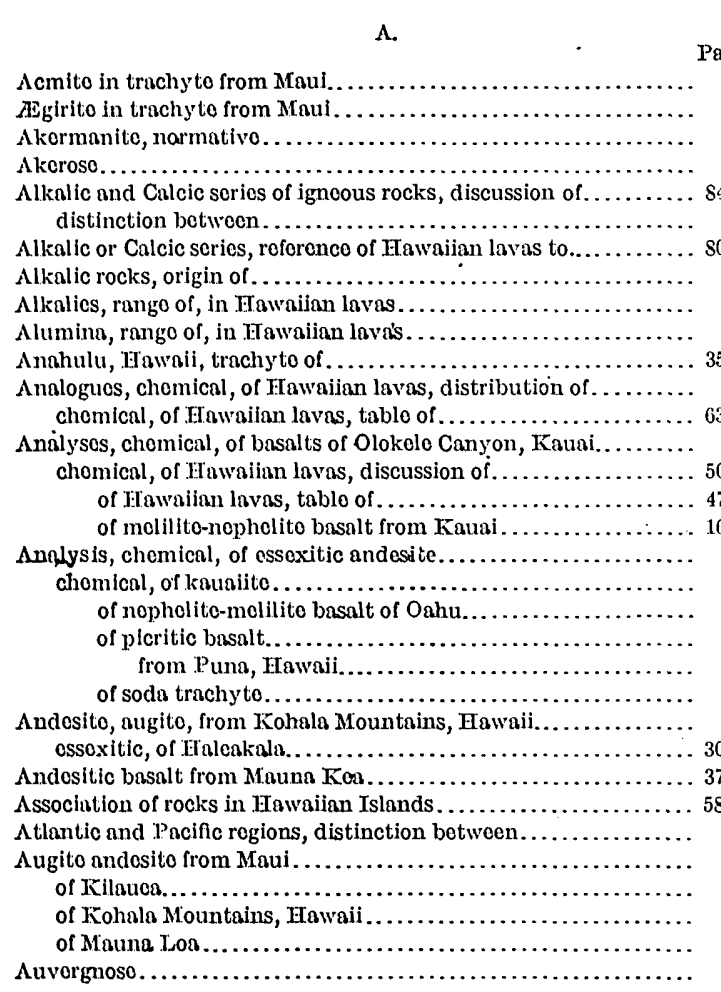

B.

Basalt, bronzito-bearing, of Oahu. nopholito-melilite, from point near Honolulu, Oahu, plate showing$$
\text { of Oahu. }
$$

nopholite, of Onhu.

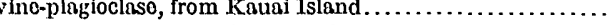

from Kauni Island, plate showing......................

from Laysan Island.

from Necker Island

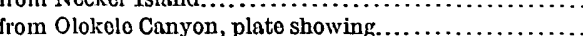

of Kilnuen.

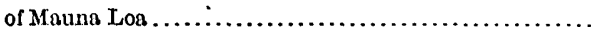

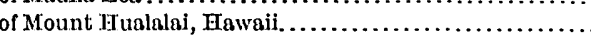

of Onhu.

of West Maui.

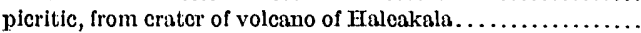

plagioclaso (poor in olivino), from Kauai.

near Lahaina, Maui.

(olivine-free) of Oahu

Basaltic tuff near Honolulu . ...............................

Basalts near Honolulu, relations of...

of Kauai assigned to Calcic series

of 'Oahu assigned to Calcic series.

"Black ash" near Honolulu, relation of, to nephelite-melilite basalt.

Bronzito-bearing basalt of Oahu.
Page.

27

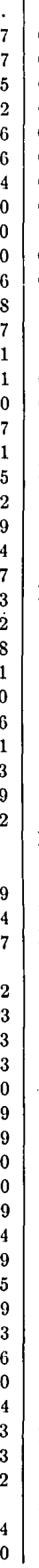

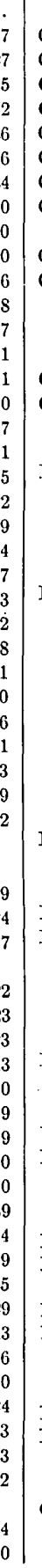

Calcic and Alkalic series of igneous rocks, discussion of Page. Calcic or Alkalic series, reference of Hawaiian lavas to ........... $80-84$ Caldera walls of Kilauea, rocks of........................... $60-61$

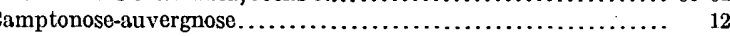

Daly, R. A., hypothesis of, as to origin of alkalic rocks......... 90 on basalt of Mauna Loa............................... on differentiation of Hawaiian magmas................. $\quad 89$ 
Gabbro, oligoclase, of Waialae River, Kauai ................ Page. sodic, from Waiale Canyon, plate showing................. 14

Gay, Francis, assistance from ........................... 14 Gravitative differentiation, discussion of............... $89-90$

$\mathrm{H}$.

Haleakala, volcano of, description of rocks from lavas of, relations of .

Hanapepe River, Kauai, limburgite of - $\ldots \ldots$

Harker, Alfred, on Atlantic and Pacific facies of igneous rocks...

Hawaii Island, rocks of...

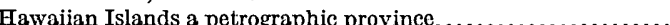

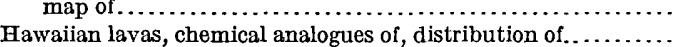
table of.

Hawaiite, name proposed by Iddings

Hillebrand, William, collection of rocks by

Hillebrand, W. F., chemical analyses by .........................

Hitchcock, C. H., acknowledgment of material from.

on explosive eruption of Kilauea.

on geology of Oahu.

on lavas of Mauna Kea.

on occurrence of nephelite-melilite basalt of Oahu.

Hualalai, Mount, Hawaii, rocks of.

\section{I.}

Iao Valley, Maui, rocks of

\section{I........}

Iddings, J. P., proposal of name "kauaiite" by ...................

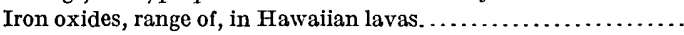

\section{K.}

Kaala Range, Oahu, rocks of

Kahoolawe Island, lack of information concerning

Kauai Island, basalts of, assigned to Calcic series. features of.

occurrence of lavas on

quantitative classification of basalts of..

relation of norm and mode in basalts or.....

Kauaiite, analysis and norm of basalts of......................

application of name to.

rame proposed by Iddings . . . . . . . . . . . . .

of Waialae River, Kauai.

Kilauea, associated lavas of

crater wall of, relations of rocks of ................... 81-82

Kilauea Bay; Kauaii, melilite-nephelite basalt of ..............

Kilaueite of Silvestri, character of

Kilauose.............................................

Klautsch, A., on lavas of Samoan Islands. . . . . . . . . . . . . . . .

Kohala Mountains, Hawaii, rocks of....................... 32-34

Kohalaite, an alkalic type.............................. 80-81 name proposed by Iddings.......................... 56

Koloa plantation, Kauai, basalt of........................ 13

Koolau Range, Oahu, rocks of.......................... 19-20

\section{L.}

Lacroix, A., on Alkalic and Calcic series of igneous rocks......... on rocks of Reunion Island.............................. on rocks of Tahiti.

Lahaina, Maui, rocks occurring near.....

Lanai Island, lack of information concerning................... 59

Larsen, E. S., acknowledgment to...........................

Laysan Island, rocks of.

Lenads, normative.

Lesser islands, rocks of...

Limburgite of Hanapepe River, Kauai

Lime, range of, in Hawaiian lavas.

Lyons, A. B., on lava from Kohala Mountains, Hawaii............. on rocks of Oahu.

\section{M.}

Magmas, Hawaiian, differentiation of..

Magmatic types, Hawaiian, world distribution of

Magnesia, range of, in Hawaiian lavas..

Manganese, range of, in Hawaiian lavas..

\section{Ma}

Maui Island, features of

25

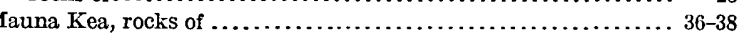

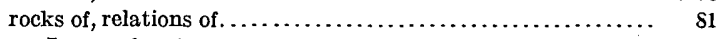

Mauna Loa, rocks of................................. 38-39

Melilite-basalt of Hawaii, origin of....................... 90

Melilite-bearing basalts.............................. 16, 20,26

Melilite-nephelite basalt near Lahaina, Maui................ 26-28 of Kilauea Bay, Kauai................................ 16-17

Merrill, G. P., acknowledgment to...................... 8, 18 on nephelite-melilite basalt of Oahu .................... 21 on Preston's collection of rocks from Mauna Kea............. 36-37 on rocks of $\mathrm{Oahu} . \ldots \ldots \ldots \ldots \ldots \ldots \ldots \ldots \ldots \ldots \ldots \ldots \ldots, 18$

Mineral composition of Hawaiian rocks................... 45-47

Mode and norm, relation of, in basalts of Kauai.............. 12-13 relation of, in Hawaiian lavas........................ 54-55

Möhle, F., on basalt of Kauai.......................... 17 on nephelite-melilite basalt near Honolulu................ 21 on rocks of Laysan and Necker islands.................. 9 on rocks of Maui..................................... 26 on rocks of Molokai.................................. 24

Moiliili Church, near Honolulu, basalt of quarry near.......... 21-22

Mokuaweoweo crater, basalts of ............................. 38

Molokai Island, basalt from................................. 24

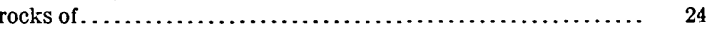

Molybdic acid in Hawaiian lavas............................. 51
26

50

Nep

19

19

Norm
Nor

O

Oahu Island, basalts of, assigned to Calcic series............. 82 description of rocks of $\ldots \ldots \ldots \ldots \ldots \ldots \ldots \ldots \ldots \ldots \ldots \ldots \ldots \ldots \ldots \ldots \ldots \ldots, 17-18$ Occult molecules of nephelite and orthoclase in basalt.......... 12-13 Occult molecules of nephelite and orthoclase in basalt............ Olivine, abnormative development of, in basalt.............. 12

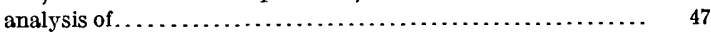
normative........................ 55 Olivine-diabase from Molokai Island ..................... 24-25 Olokele Canyon, Kauai, analyses of basalts from .............. 11

$$
P \text {. }
$$

Pacific and Atlantic regions, distinction between.

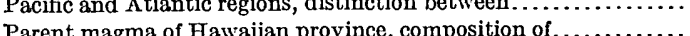

87

Pearl Harbor, Oahu, rocks of .......................... 19

Peridotite as xenoliths, occurrence of.................. 13,34,38

Perret and Shepherd, lava collected by.................... 41

Petrographic province, Hawaiian, parent magma of ........... 87

Picritic basalt from Puna, Hawaii........................ 43 from Puna, Hawaii, relations of .......................... 83 of crater of Haleakala................................. 28-29

of Mauna Loa................................... $\quad 39$

of Mauna Loa and Haleakala, relations of............... 83

Plagioclase, character of, in Hawaiian rocks................ 45-46

Potash in volcanic ash near Honolulu..................... 24

Preston, E. D., rocks from Mauna Kea collected by ........... $\quad 36$

Provincial magma of Hawaiian Islands, composition of........... 87

Publications cited................................ 8-9

Puna district, Hawaii, rocks of . . . . . . . . . . . . . . . . . . .

Puu Waawaa, Hawaii, trachyte of . . . . . . . . . . . . . . . 
INDEX.

Q.

Qualitative classiflcation of Hawailan lavas

Quantitativo classification of basalts of Kauai

of Hawalian lavas.

of kauaitito.

of lavas from Fraloakala.

of molilite-nephelite basalt of Kaua

of nopholite-melilite basalt of Oahu.

of picritic basalt.

of picritic basalt from Puna, Hawaii.

of soda trachy to.

Quartz, normative, in basaltic lavas of Hawaii

R.

Rounion Island, rocks of, analogous to Hawalian lavas .

Rosonbusch, H., on Alkalic and Calcic series of igneous rocks........ 84-86

S.

Salic moloculos in norms of Hawaiian lavas...

53

Samoan Islands, rocks of, analogous to Hawaiian lavas......... 79

Schaller, W. T., analysis by.

analysis of kauailito by.

on minorals in kauaitite.

Schnuinsland, $\mathrm{H}$, collection of rocks by

Soquence of Hawaiian lavas.

Sillica, modal, in Hawailan lavas.

rango of, in Hawaiian lavas.

Sllvestri, O., on rocks of Kilauea.

Smyth, C. HI., Jr., on origin of Alkalic rocks.

Soda trachyto, chomical analysis of.. noar Lahaina, Maui.

Page.

$55-56$

12

$56-58$

15

32

7

2

4

28

U

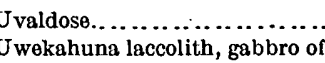

Vioira's ranch,

(1)

Vieira's ranch, Maui, analysis of lava from point near .......... 31

W.

Waihee Valley, Maui, rocks of .......................... 25-26

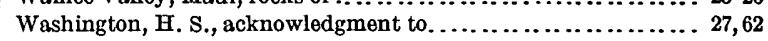
on distinction between Alkalic and Caicic series............... 86

Weber, Max, on distinction between Alkalic and Calcic series.... 86 on rocks of Samoan Islands ......................... 79

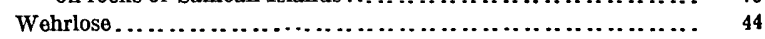

Wells, R. C., analysis by .............................. 11

West Maui, rocks of ................................... 25

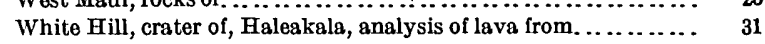
description of lava from ............................. $30-31$

Wichmann, A., on nephelite-melilite basalt of Oahu............ 20

Wilcox, E. V., on potash in volcanic ash near Honolulu. ......... 24

World distribution of Hawaiian magmatic types............... 62

$\mathrm{X}$.

Xenoliths in basalt of Mount Hualalai, Hawaii................ 34-35 in lavas of Mauna Kea............................... 38 in limburgite of Kauai............................... 13

Tacchind, $P .$, colloction of rocks by $\ldots \ldots \ldots \ldots \ldots \ldots \ldots \ldots \ldots \ldots$.
Tahitl, rocks of, analogous to Hawaiian lavas................... ${ }_{78}^{7}$

Theoretical bearings of data presented on Hawailan rocks........ 80-93

$48730-15-7$ 